\title{
A Literature Survey: Methods for the Removal of lodine Species from Off-Gases and Liquid Waste Streams of Nuclear Power and Nuclear Fuel Reprocessing Plants, with Emphasis on Solid Sorbents
}
D. W. Holladay

\section{OAK RIDGE NATIONAL LABORATORY} OPERATED BY UNION CARBIDE CORPORATION · FOR THE DEPARTMENT OF ENERGY 


\section{DISCLAIMER}

This report was prepared as an account of work sponsored by an agency of the United States Government. Neither the United States Government nor any agency Thereof, nor any of their employees, makes any warranty, express or implied, or assumes any legal liability or responsibility for the accuracy, completeness, or usefulness of any information, apparatus, product, or process disclosed, or represents that its use would not infringe privately owned rights. Reference herein to any specific commercial product, process, or service by trade name, trademark, manufacturer, or otherwise does not necessarily constitute or imply its endorsement, recommendation, or favoring by the United States Government or any agency thereof. The views and opinions of authors expressed herein do not necessarily state or reflect those of the United States Government or any agency thereof. 


\section{DISCLAIMER}

Portions of this document may be illegible in electronic image products. Images are produced from the best available original document. 


\section{Printed in the United States of America. Available from National Technical Information Service \\ U.S. Department of Commerce \\ 5285 Port Royal Road, Springfield, Virginia 22161 \\ Price: Printed Copy $\$ 9.00$; Microfiche $\$ 3.00$}

This report was prepared as an account of work sponsored by an agency of the United States Government. Neither the United States Government nor any agency thereof, nor any of their employees, contractors, subcontractors, or their employees, makes any warranty, express or implied, nor assumes any legal liability or responsibility for any third party's use or the results of such use of any information, apparatus, product or process disclosed in this report, nor represents that its use by such third party would not infringe privately owned rights. 
Contract No. W-7405-eng-26

CHEMICAL TECHNOLOGY DIVISION

A LITERATURE SURVEY: METHODS FOR THE REMOVAL OF IODINE SPECIES FROM OFF-GASES AND LIQUID WASTE STREAMS OF NUCLEAR POWER AND NUCLEAR FUEL REPROCESSING PLANTS, WITH EMPHASIS ON SOLID SORBENTS

D. W. Holladay

Date Published: January 1979

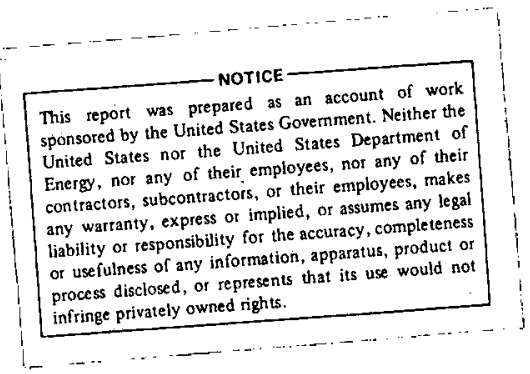

NOTICE This document contains information of a preliminary nature It is subject to revision or correction and therefore does not represent a final report.

OAK RIDGE NATIONAL LABORATORY

Oak Ridge, Tennessee 37830 operated by

UNION CARBIDE CORPORATION

for the

DEPARTMENT OF ENERGY 
THIS PAGE WAS INTENTIONALLY LEFT BLANK 
Abstract ........................... . 1

1. Introduction . . . . . . . . . . . . . . . . 2

2. Iodine Species Removal from Fuel Reprocessing Off-Gases by Liquid-Gas Scrubbing Operations . . . . . . . . . . . . 4

2.1 Iodox Process ................... . 5

2.1.1 Background .................. 5

2.1.2 Chemical mechanism . . . . . . . . . . 6

2.1.3 Experimental results and engineering data useful for process design . . . . . . . . . . . 8

2.1 .4 Process capacity . . . . . . . . . . . . . 14

2.1.5 Present process application . . . . . . . . 14

2.1 .6 Process advantages.............. . 20

2.1.7 Process disadvantages ............ 22

2.2 Mercuric Nitrate--Nitric Acid Scrubbers . . . . . . 23

2.2.1 Background . . . . . . . . . . . . . 23

2.2.2 Chemical mechanisms . . . . . . . . . . 24

2.2.3 Experimental results and engineering data usefu1 for process design . . . . . . . . . . 26

2.2.4 Process capacity . . . . . . . . . . . 30

2.2.5 Current process application . . . . . . . 30

2.2.6 Process advantages............. 31

2.2.7 Process disadvantages . . . . . . . . . . 32

3. The Removal of Iodine Species from Off-Gases by Utilizing Solid

Sorbents . . . . . . . . . . . . . . . . . . 33

3.1 Removal of Iodine Species from Nuclear Reactor Operation Off-Gases by Utilizing Activated Charcoal . . . . . . 34

3.1.1 Background . . . . . . . . . . . . . 34

3.1.2 Chemical mechanism . . . . . . . . . . 37

3.1.3 Standard operating conditions for activated charcoal beds utilized in iodine species removal from nuclear power plant off-gases . . . . . . . 39 
3.1.4 Experimental results and present applications of activated charcoal to filter iodine species from nuclear facility off-gases.......... . 40

3.1.5 Process capacity............... 44

3.2 Removal of Iodine Species from off-Gases by Utilizing Metal-Exchanged Zeolites . . . . . . . . . . 46

3.2.1 Background . . . . . . . . . . . . . . 46

3.2.2 Chemical mechanism . . . . . . . . . . . 46

3.2.3 Experimental results and engineering data useful for process design. . . . . . . . . . . . 46

3.2.4 Process capacity . . . . . . . . . . . 56

3.2.5 Present application ............ . 59

3.2.6 Advantages . . . . . . . . . . . . . 60

3.2.7 Disadvantages . . . . . . . . . . . 60

3.3 Removal of Iodine Species from Gases by Utilizing Silver Nitrate-Impregnated, Amorphous Silicic Acid (Ag-KTB and AC-6120)

3.3.1 Background ................. 61

3.3.2 Chemical mechanisms . . . . . . . . . . 62

3.3.3 Experimental results and engineering data useful for process design . . . . . . . . . . 62

3.3.4 Present applications . . . . . . . . . . 66

3.3.5 Process capacity . . . . . . . . . . . 69

3.3.6 Process advantages .. . . . . . . . . . 69

3.3.7 Process disadvantages ............ . 70

3.4 Removal of Iodine Species from Gases by Utilizing Silver and Lead Mordenites... . . . . . . . . . . 70

3.4.1 Background . . . . . . . . . . . . . . 70

3.4.2 Chemical mechanisms . . . . . . . . . . . 71

3.4.3 Experimental results and engineering data useful for process design . . . . . . . . . . . 72

3.4.4 Present applications . . . . . . . . . . . 75

3.4.5 Process capacity . . . . . . . . . . . . 76

3.4.6 Process advantages ............... 76

3.4.7 Process disadvantages ............ . 79 
THIS PAGE

WAS INTENTIONALLY

LEFT BLANK 
CONTENTS (Cont'd)

$\underline{\text { PAGE }}$

3.5 Removal of Iodide Species from Gases by Utilizing Macroreticular Resins . . . . . . . . . . . 81

3.5.1 Background . . . . . . . . . . . . 81

3.5.2 Chemical mechanisms . . . . . . . . . . 81

3.5.3 Experimental results and engineering data useful for process design . . . . . . . . . . 81

3.5.4 Present application . . . . . . . . . . 85

3.5.5 Process capacity .............. 85

3.5.6 Process advantages . . . . . . . . . . . 86

3.5.7 Process disadvantages ............ 86

4. Methods of Removing Iodine Species from Fuel Reprocessing

Waste Liquid Streams . . . . . . . . . . . . . 86

4.1 Background and Introduction . . . . . . . . . . 86

4.2 Removal of Iodine Species from Liquid Streams Utilizing Activated Charcoal . . . . . . . . . . . . 89

4.2.1 Background . . . . . . . . . . . . . . 89

4.2.2 Chemical species of dissolved iodine... . . . 89

4.2.3 Experimental results and engineering data useful for process design . . . . . . . . . . 92

4.2.4 Present applications . . . . . . . . . . . . . 99

4.2.5 Process capacity . . . . . . . . . . . . 99

4.2.6 Process advantages . . . . . . . . . . . 100

4.2.7 Process disadvantages . . . . . . . . . . 100

4.3 Removal of Iodine Species from Liquid Streams by

Utilizing Macroreticular Resins . . . . . . . . 101

4.3.1 Background . . . . . . . . . . . . . 101

4.3.2 Physical properties . . . . . . . . . . . 102

4.3.3 Experimental results and engineering data useful for process design . . . . . . . . . . . 103

4.3.4 Present applications . . . . . . . . . . . 112

4.3.5 Process capacity . . . . . . . . . . . . 112

4.3.6 Process advantages . . . . . . . . . . . 113

4.3.7 Process disadvantages . . . . . . . . . 114 
$\underline{\text { PAGE }}$

4.4 Removal of Iodine Species from Aqueous Streams by Utilizing Anion Exchange Resins . . . . . . . . . . 115

4.4.1 Background . . . . . . . . . . . . . . 115

4.4.2 Chemical mechanism . . . . . . . . . . . 117

4.4.3 Experimental results and engineering data useful

for process design . . . . . . . . . . . 118

4.4.4 Present applications .. . . . . . . . . . 125

4.4.5 Process capacity ............... . 134

4.4.6 Process advantages .............. . 134

4.4.7 Process disadvantages ............ 135

5. Summary . . . . . . . . . . . . . . . . . 135

5.1 Methods for Removal of Iodine Species from Off-Gases . . 136

5.2 Methods for Removing Iodine Species from Dilute Aqueous

Solutions..................... 143

Appendix A . . . . . . . . . . . . . . . . . 149

References . . . . . . . . . . . . . . . . . 151 
A LITERATURE SURVEY: METHODS FOR THE REMOVAL OF IODINE SPECIES FROM OFF-GASES AND LIQUID WASTE STREAMS OF NUCLEAR POWER AND NUCLEAR FUEL REPROCESSING PLANTS, WITH EMPHASIS ON SOLID SORBENTS

D. W. Holladay

\section{ABSTRACT}

A literature survey was conducted to provide information for the assessment of the various processes available for removing iodine species from the off-gases and from the lowlevel-radwaste aqueous streams that arise at nuclear power facilities and nuclear fuel reprocessing plants. Particular emphasis was focused on the operating parameters that most strongly affected the optimization of the processes used to treat actual process or feed streams which simulated actual compositions occurring at nuclear facilities. These parameters included gas superficial velocity, temperature, types of organic and inorganic contaminants, relative humidity, iodine feed-gas concentration, iodine species, column design (for both acid-scrub and solid sorbent-based processes), sorbent particle size, run time, intense radiation (solid sorbents only), and scrub-acid concentration. Based on the ability of a process to deliver high decontamination factors and high loading capacity for iodine species under practical operating conditions, the most promising acid-scrub process for removal of iodine species from off-gases appears to be Iodox. The most promising solid sorbent for removal of iodine species from off-gases is the West German Ag-KTB-AgNO3-impregnated amorphous silicic acid. The tandem silver mordenite--lead mordenite sorbent system is also quite attractive. Only a limited number of processes have thus far been studied for removal of iodine species from lowlevel liquid waste streams. The most extensive successful operating experience has been obtained with anion exchange resins utilized at nuclear power reactors. Bench-scale engineering tests have indicated that the best process for removal of all types of iodine species from liquid waste streams may be treatment on a packed bed containing a mixture of sorbents with affinity for both elemental and anionic species of iodine. Further experimentation at the pilot plant scale, comparison of the ease of process operations under remote handling conditions, and in-depth cost analyses should be made before the final process is chosen for removal of iodine species from either off-gases or liquid wastes. 


\section{INTRODUCTION}

One of the major fission products of nuclear power reactors is ${ }^{129} \mathrm{I}$, which constitutes a radionuclide hazard both at power plants and when released as organic iodides and elemental iodine into the process off-gas of nuclear fuel reprocessing plants. A model Light-Water Reactor (LWR) fuel reprocessing plant, such as that of Allied-Genera1. Nuclear Services (AGNS) at Barnwe11, South Carolina, would process annually fuel that contained 1500 metric tons of heavy metal (MTHM, uranium plus plutonium) as charged to reactors that produce about 42,000 MW(e)-year of energy while operating for one year. This 1500 MTHM would contain more than $50 \mathrm{Ci}$ of ${ }^{129} \mathrm{I}$ ( $>300 \mathrm{~kg}$ ) and, when processing is performed at 160 days after discharge of fuel from the reactors, greater than $1000 \mathrm{Ci}$ of ${ }^{131} \mathrm{I}$ (>10 mg). ${ }^{1}$ Much of this iodine would be discharged from the plant in the stack gas unless extensive iodine recovery systems were applied. The current EPA release limits $^{2}$ for iodine require that normal operations within the uranium fuel cycle be conducted to provide reasonable assurance that: (1) the annual dose equivalent does not exceed 25 millirems to the whole body, 75 millirems to the thyroid, and 25 millirems to any other organ of any member of the public; and (2) the quantity of ${ }^{129}$ I released to the environment per gigawatt-year of power produced by the entire fuel cycle does not exceed $5 \mathrm{mCi}$.

Detailed analyses of different levels of sophistication in fuel reprocessing design to achieve ${ }^{129}$ I control (along with other major reactor products) have been described. ${ }^{3,4}$ Seven cases and their corresponding flowsheets for treating the gaseous and liquid streams for a 
model LWR fuel reprocessing plant are discussed in ref. 3. The lowestcost and simplest-treatment technology were presented for the base Case 1 . For each succeeding case, additional processes were considered which either initiated or enhanced the removal of the basic off-gas fission products. The most elaborate plant design was given in Case 7 , in which "near zero release" concepts were applied to treatment and/or recycle of gaseous and liquid effluents. The studies described in refs. 3 and 4 served as valuable guidelines for providing the reference processes, stream flow rates, and stream compositions to be reviewed in this survey.

During nuclear fuel reprocessing, most of the radioiodine that has been produced in the reactor fuel (from tellurium decay) is released into the dissolver off-gas during dissolution and subsequent sparging procedures. This iodine appears mostly as elemental iodine and aliphatic iodides, although very low concentrations of more complex inorganic and organic iodides may be present. Those systems which are candidates for iodine species removal from the off-gas must be capable of trapping both inorganic and organic iodides and should maintain acceptable removal efficiencies for off-gas streams containing water vapor, tritiated water, carbon dioxide, noble gases, nitrogen oxides, and organics evolved during solvent extraction. Candidate processes for iodine species removal from off-gases are:

1. Iodox;

2. mercuric nitrate--nitric acid scrubbers; and

3. sorption on the solid sorbents, including

(a) silver and base-metal zeolites,

(b) silver and base-metal mordenites,

(c) silver-nitrate impregnated, amorphous silicic acid, and

(d) macroreticular resins. 
Most of the iodine that is carried with the aqueous stream from the dissolver is volatilized in the feed adjustment-iodine evolution step; thus only a small fraction of the original iodine in the nuclear fuel manages to enter the solvent extraction system. Waste streams (primarily aqueous with ${ }^{129} \mathrm{I}$ and trace organics) from the solvent extraction system, the high-activity waste treatment $100 \mathrm{p}$, and the nitric oxide-nitric acid scrubber will be processed in the low-activity liquid waste process loop. These waste liquid streams may contain levels of iodine intolerable for release. Increased emphasis on "near-zero release" constraints placed on fuel reprocessing plants makes it imperative to treat these combined waste streams (either as a vapor or in both vapor and condensate states) for iodine removal before the streams are recycled or released to the atmosphere.

Candidate processes for iodine removal from neutral and mildly acidic streams are: (1) macroreticular resins, (2) charcoal, (3) ion exchange resins, and (4) metal oxide-impregnated sorbents.

A literature survey was conducted to provide information concerning the background, experimental development, and present status of each of the above processes for removing iodine species from gas and/or aqueous streams.

\section{IODINE SPECIES REMOVAL FROM FUEL REPROCESSING OFF-GASES} BY LIQUID-GAS SCRUBBING OPERATIONS

Although the primary goal of this review was to assess the capabilities of various solid sorbents for removing radioiodine species from liquid and gaseous wastes, two processes based on transfer of iodine between 
gaseous and acidic streams were reviewed. Iodox and the mercuric nitratenitric acid iodine removal processes were summarized because of their proven ability and wide acceptance for achieving high removal efficiencies for elemental iodine and aliphatic iodides. In addition, much of the effort that has been devoted to studying the iodine chemistry in these processes could contribute to a better understanding of the complex sorption chemistry involved in solid sorbent interaction with iodine in mildly acidic and neutral streams. Finally, any arguments that are to be made for utilization of solid sorbents as the primary or secondary procedure for iodine removal must also include a consideration of the two most efficient methods utilizing acidic solutions for scrubbing iodine from process gases.

\subsection{Iodox Process}

\section{1 .1 Background}

The Iodox process is an advanced procedure for scrubbing elemental iodine and organic iodides from off-gases by utilizing hyperazeotropic $(>20 \mathrm{M}) \mathrm{HNO}_{3}$ in a gas-liquid contactor. The process appears to be adaptable not only for treating primary dissolver off-gas but also as a final polishing step for off-gas containing very low levels of iodine such as previously scrubbed dissolver off-gases or off-gas streams from particular process vessels. The primary unit operations for an integrated Iodox system are: (1) absorption of iodine species and oxidation to soluble, nonvolatile pentavalent iodate with hyperazeotropic $\mathrm{HNO}_{3}$ in a gas-1iquid column (preferably bubble-cap); (2) concentration of iodinerich $\mathrm{HNO}_{3}$ scrub solution in an evaporator; (3) recycle of iodine-free 
$\mathrm{HNO}_{3}$ concentrate from the evaporator to the plant $\mathrm{HNO}_{3}$ system; and (4) transfer of iodine-nitric acid concentrate from the first evaporator to a second evaporator where it is collected as the pentavalent iodine in a dehydrated form of $\mathrm{HI}_{3} \mathrm{O}_{8}$.

\subsubsection{Chemical mechanism}

Mailen ${ }^{5}$ has written an excellent review of four processes that have been developed on an engineering scale for removing iodine species from off-gases. The specific focus of that review was on evaluation of the chemical mechanisms involved with four iodine-trapping systems. The systems included iodine removal by both acidic scrubbing solutions and solid sorbent beds.

To better understand the Iodox process and to develop correlations that could be useful in future engineering scale-up considerations, the chemistry of the Iodox process has been studied in depth. The reaction between iodine and hyperazeotropic $\mathrm{HNO}_{3}$ has been intensively studied. $^{6-8}$ The equilibrium and kinetic data were consistent with the two-step reaction:

$$
\begin{gathered}
\mathrm{I}_{2}+4 \mathrm{HNO}_{3} \underset{\mathrm{k}_{2}}{\stackrel{\mathrm{k}_{1}}{\rightleftarrows}} 2 \mathrm{I}^{+}+2 \mathrm{NO}_{3}^{-}+\mathrm{N}_{2} \mathrm{O}_{4}+2 \mathrm{H}_{2} \mathrm{O}, \\
\mathrm{I}^{+}+3 \mathrm{HNO}_{3}+\mathrm{NO}_{3} \underset{\mathrm{k}_{4}}{\stackrel{\mathrm{k}_{3}}{\rightarrow}} \mathrm{IO}_{3}^{-}+\mathrm{H}^{+}+2 \mathrm{~N}_{2} \mathrm{O}_{4}+\mathrm{H}_{2} \mathrm{O} .
\end{gathered}
$$

Generally, the first reaction proceeds rapidly, but the second is relatively slow. Thus at short reaction times, when the $\mathrm{N}_{2} \mathrm{O}_{4}$ content of the liquid is small, another equilibrium is rate controlling. Although the 
kinetics and stoichiometry were not elucidated for this equilibrium reaction, it can be represented by: ${ }^{9}$

$$
\mathrm{K}_{3}=\frac{\mathrm{C}_{\mathrm{I}^{+}}}{\mathrm{C}_{\mathrm{I}_{2}}} \text {, }
$$

where $\mathrm{C}_{\mathrm{I}}+$ and $\mathrm{C}_{\mathrm{I}_{2}}$ are molar concentrations of $\mathrm{I}^{+}$and $\mathrm{I}_{2}$ respectively. For increased $\mathrm{N}_{2} \mathrm{O}_{4}$ concentrations, the equilibrium for Eq. (1) controls:

$$
\mathrm{K}_{1}=\frac{{ }_{\mathrm{C}}{ }^{+{ }^{2} \mathrm{C}_{\mathrm{N}_{2} \mathrm{O}_{4}}}}{\mathrm{C}_{\mathrm{I}_{2}}}
$$

and

$$
\ln \mathrm{K}_{1}=48.1-17.4 \ln \mathrm{C}_{\mathrm{HNO}_{3}} \text {, }
$$

where $\mathrm{C}_{\mathrm{N}_{2} \mathrm{O}_{4}}$ is the molar concentration of $\mathrm{N}_{2} \mathrm{O}_{4}$. For the assumption of a pseudo-first-order reaction, the consumption of $\mathrm{I}^{+}$to $\mathrm{IO}_{3}{ }^{-}$, based on reaction (2), can be described by:

$$
\frac{\mathrm{dC}_{\mathrm{I}^{+}}^{+}}{\mathrm{dT}}=-\mathrm{k}_{3} \mathrm{C}_{\mathrm{I}^{+}}
$$

Values of $k_{3}$ can be calculated from (ref. 7),

$$
\text { In } \mathrm{k}_{3}=-45.25+13.69 \ln \mathrm{C}_{\mathrm{HNO}_{3}} \text {, }
$$

where $k_{3}$ is the rate constant in $\mathrm{sec}^{-1}$ and $\mathrm{C}_{\mathrm{HNO}_{3}}$ is the $\mathrm{HNO}_{3}$ molarity. It was determined ${ }^{10}$ that the data for the distribution of elemental iodine between air and $\mathrm{HNO}_{3}$ at $25^{\circ} \mathrm{C}$ fit the equation:

$$
\mathrm{K}_{\mathrm{G}}^{\mathrm{L}}=98.2-1.11 \mathrm{C}_{\mathrm{HNO}_{3}} \text {, }
$$

where the distribution coefficient $\mathrm{K}_{G}{ }^{\mathrm{L}}$ is (moles of $\mathrm{I}_{2} /$ iiter of liquid)/ (moles $\mathrm{I}_{2} /$ liter of gas). Because of the importance of $\mathrm{NO}_{2}$ in the Iodox 
process [it is in equilibrium reaction (1) and is a major component of fuel reprocessing off-gases], study of the distribution of $\mathrm{NO}_{2}$ between air and hyperazeotropic $\mathrm{HNO}_{3}$ was begun. ${ }^{11}$ Initial data indicated that at a high temperature the equilibrium

$$
2 \mathrm{NO}_{2}(\mathrm{~g}) \stackrel{\rightarrow}{\leftarrow} \mathrm{N}_{2} \mathrm{O}_{4}(l)
$$

could have a strong effect on the Iodox process.

An actual fuel reprocessing off-gas stream will contain organic iodides such as methyl iodide $\left(\mathrm{CH}_{3} \mathrm{I}\right)$ in addition to $\mathrm{I}_{2}$; it was therefore necessary to consider the effect of other such iodides on the reactivity of $\mathrm{I}_{2}$ in Iodox. The initial reaction of $\mathrm{CH}_{3} \mathrm{I}$ in hyperazeotropic $\mathrm{HNO}_{3}$ is a fast nitrolysis: ${ }^{12}$

$$
\mathrm{CH}_{3} \mathrm{I}+2 \mathrm{HNO}_{3} \stackrel{\mathrm{k}_{5}}{\rightarrow} \mathrm{CH}_{3} \mathrm{NO}_{3}+1 / 2 \mathrm{I}_{2}+1 / 2 \mathrm{~N}_{2} \mathrm{O}_{4}+\mathrm{H}_{2} \mathrm{O}
$$

The $I_{2}$ formed from the initial $I_{2}$ conversion then reacts as if it were normal $\mathrm{I}_{2}$ in the previously discussed reactions (1) and (2). The $\mathrm{CH}_{3} \mathrm{I}$ decontamination factors (DFs) obtained in Iodox for equal feed concentrations are less than those for $\mathrm{I}_{2}$ because of the considerably lower distribution of $\mathrm{CH}_{3} \mathrm{I}$ from air to $\mathrm{HNO}_{3} \cdot 10,13$ The methy 1 nitrate distributes favorably from $\mathrm{HNO}_{3}$ to air by a factor of about 15; thus the hazard of explosion caused by $\mathrm{CH}_{3} \mathrm{NO}_{3}$ buildup is reduced, because most of the $\mathrm{CH}_{3} \mathrm{NO}_{3}$ leaves the Iodox system in the treated off-gas stream.

\subsubsection{Experimental results and engineering data useful for process design}

The Iodox contactor as a packed column. The Iodox process was originally called Iodex and involved the removal of $\mathrm{I}_{2}$ and $\mathrm{CH}_{3} \mathrm{I}$ from air by countercurrent scrubbing with $\geq 70 \% \mathrm{HNO}_{3}$ in a packed column. Only the 
summary Iodex report ${ }^{14}$ is reviewed here to provide background information on the original development of the iodine- $\mathrm{HNO}_{3}$ scrubbing concept and to indicate the evolution of the integrated Iodox process. The countercurrent Iodox process was conducted in glass towers $0.04 \mathrm{~m}$ in diam and 0.56 or $1.17 \mathrm{~m}$ long. Packing was $6.4 \times 10^{-3}-\mathrm{m}(1 / 4-\mathrm{in}$.$) ceramic Ber 1$ saddles. To remove elemental iodine from air, the DFs were as much as $3.5 \times 10^{4}$ in the $0.56-\mathrm{m}$ column ( $1.3 \times 10^{8} / \mathrm{m}$ of packing).

Iodine and $\mathrm{CH}_{3} \mathrm{I}$ feed concentrations were in the range 20 to 4000 ppm. Appendix A describes the general concentration ranges that are anticipated for nuclear power plant and fuel reprocessing off-gases.

The DFs for iodine species removal $\left(\mathrm{I}_{2}\right.$ and $\left.\mathrm{CH}_{3} \mathrm{I}\right)$ were determined to vary directly with temperature and $\mathrm{HNO}_{3}$ concentration, and inversely with gas superficial velocity. These observations were consistent with a mass transfer process for which the controlling diffusional resistance was in the liquid film, and the chemical conversion of iodine to iodate was essentially first order. Acceptable scrubbing efficiencies for $I_{2}$ removal were obtained at $>80^{\circ} \mathrm{C}$ with $70 \% \mathrm{HNO}_{3}$, or at $>30^{\circ} \mathrm{C}$ with $80 \% \mathrm{HNO}_{3}$. Methyl iodide was less effectively removed than $\mathrm{I}_{2}$ (maximum $\mathrm{DF}$ for $\mathrm{CH}_{3} \mathrm{I}$ of $9.6 \times 10^{4} / \mathrm{m}$ for a $1.17-\mathrm{m}$ long column vs maximum $\mathrm{DF}$. for $\mathrm{I}_{2}$ of $1.3 \mathrm{x}$ $10^{8} / \mathrm{m}$ for a $0.56-\mathrm{m}$ column). Boiling temperatures were necessary to achieve efficient removal of $\mathrm{CH}_{3} \mathrm{I}$ for acid concentrations of $70 \% \mathrm{HNO}_{3}$. In very limited tests, the addition of a hexane contaminant to the feed gas had 1ittle effect on the DF for a once-through liquid flow of $\mathrm{CH}_{3} \mathrm{I}$. When hexane was added with $\mathrm{CH}_{3} \mathrm{I}$ to a feed gas in the $0.04-$ by $1.17-\mathrm{m}$ packed column, the DF for $\mathrm{CH}_{3} \mathrm{I}$ was reduced by a factor of 5 when the scrub acid was recycled. However, the $\mathrm{DFs}$ for $\mathrm{CH}_{3} \mathrm{I}$ removal from 
air $-\mathrm{CH}_{3} \mathrm{I}$-aromatic mixtures in the packed column were minimally affected by benzene and iodobenzene (at very low concentration).

The data obtained from the operation of the laboratory-scale Iodex process were utilized to make some preliminary estimates for scaling-up the operation. Based on the small column, it was estimated that to remove iodine species from a $2.8-\mathrm{m}^{3} / \mathrm{min}$ (100 scfm) air stream (air only, with no contaminants) so that a DF of $10^{6}$ could be achieved for $\mathrm{CH}_{3} \mathrm{I}$ by utilizing $18.0 \mathrm{M}^{\mathrm{MNO}}$ at $60^{\circ} \mathrm{C}$, a packed column that was $0.86 \mathrm{~m}$ ID by $2.51 \mathrm{~m}$ long would be sufficient.

Based on the Iodex experience, the Iodox process was designed to operate with very large $\mathrm{HNO}_{3}$ concentrations, and the primary contactor design was changed to a bubble-cap column to maximize liquid holdup while retaining lower liquid velocities than are used for a packed column. The Iodox contactor as a bubble-cap column. To extend the development of the Iodox process to a more practical gas-liquid contactor, the removal of $\mathrm{I}_{2}$ and $\mathrm{CH}_{3} \mathrm{I}$ from air with hyperazeotropic $\mathrm{HNO}_{3}$ was studied in a $0.076-m-I D$ bubble-cap column..$^{15}$ It was found that:

1. Bubble-cap columns were superior for the primary Iodox contactor because scrubbing acid is conserved, and long residence times are gained at the low operating liquid flow rates,

2. For scrubbing $\mathrm{CH}_{3} \mathrm{I}$ from air, DFs for the individual plates were about 3. Larger DFs between 5 and 10 could be obtained by lowering the air flow rate or by increasing $\mathrm{HNO}_{3}$ concentrations to $21 \underline{\mathrm{M}}$, 
3. In a test of simulated HTGR feed gases (those which would contain large amounts of carbon dioxide), $\mathrm{CO}_{2}$ had no effect on DFs for $\mathrm{CH}_{3} \mathrm{I}$,

4. The DFs for $\mathrm{I}_{2}$ removal were larger than those for $\mathrm{CH}_{3} \mathrm{I}$ in a test gas containing $\mathrm{I}_{2}, \mathrm{CO}_{2}$, and $\mathrm{CO}$ in air; $\mathrm{CO}$ and $\mathrm{CO}_{2}$ apparently had a minimal effect on the process,

5. No measurable reduction in scrubbing effectiveness occurred as the number of plates increased and the corresponding $\mathrm{CH}_{3} \mathrm{I}$ concentration in the gas stream. decreased. For example, as the feed-gas $\mathrm{CH}_{3} \mathrm{I}$ concentration was reduced from $170 \mathrm{ppm}$ to $0.04 \mathrm{ppm}$ on seven plates, the DF per plate remained at $\sim 3.0$. This observation indicated that Iodox could be utilized for secondary polishing treatment.

Correlations useful for engineering scale-up. Both Mailen ${ }^{9}$ and Groenier ${ }^{15}$ derived expressions that were useful in describing the experimental nature of the Iodox process. The development of Mailen's correlation was dependent on the basic assumption that equilibrium existed at each plate of the bubble-cap column, whereas Groenier's expressions were developed by assuming that film diffusion, not chemical equilibria, was the controlling factor for packed-bed and bubble-cap scrubbing of iodine with $\mathrm{HNO}_{3}$.

Mailen utilized laboratory data for the gas- $-\mathrm{HNO}_{3}$ distribution of $\mathrm{I}_{2}$ [Eq. (8)], chemical equilibria [Eqs. (3) and (4)], and kinetics [Eqs. (6) and (7) ] to derive a correlation to predict the DF for the Iodox process in a bubble-cap column. With no $\mathrm{NO}_{2}$ or other contaminants 
present, the values calculated from Mailen's model for removal of $I_{2}$ from air agreed well with experimental data obtained in a $0.0254-\mathrm{m}$-ID bubble-cap column. For the more realistic case of trapping $\mathrm{I}_{2}$ from gas streams containing $\mathrm{NO}_{2}$, the following assumptions were made: (I) the $\mathrm{I}_{2}$ in the liquid phase was neglected; (2) $\mathrm{I}_{2}$ was the only volatile species; (3) the equilibrium of Eq. (3) was obeyed; and (4) conversion of $\mathrm{I}^{+}$to $\mathrm{IO}_{3}{ }^{-}$was negligible. The model predicted unrealistically high DFs for stages past 3 (the maximum theoretical DF is 37 for one bubble plate in the absence of $\mathrm{NO}_{2}$ ) for the cases of 1 and $2 \% \mathrm{NO}_{2}$ in the feed gas.

Mailen also developed a correlation to predict the DF for $\mathrm{CH}_{3} \mathrm{I}$ removal from air in a bubble-cap column by utilizing. Eq. (10) for the $\mathrm{CH}_{3} \mathrm{I}-\mathrm{HNO}_{3}$ reaction and the model of a gas-liquid bubbler with no $\mathrm{NO}_{2}$. There was a greater difference between the calculated and experimental DFs for $\mathrm{CH}_{3} \mathrm{I}$ removal than between the calculated and experimental DFs for $\mathrm{I}_{2}$ removal in bubble-cap columns in the absence of $\mathrm{NO}_{2}$.

It should be stressed that Mailen's correlations were derived for simple gas compositions such as air containing either $\mathrm{I}_{2}$ or $\mathrm{CH}_{3} \mathrm{I}$ with or without $\mathrm{NO}_{2}(1$ to $2 \%)$. These correlations are not applicable to actual fuel reprocessing off-gases which would contain both $\mathrm{I}_{2}$ and organic iodides, trace organics, water, noble gases, $\mathrm{CO}_{2}$ and $\mathrm{CO}$, and air as the balance. However, the chemical mechanism data and correlations for estimating the DF were very useful in predicting trends in the Iodox process. As will be discussed later, the correlations correctly estimated the effect of high $\mathrm{NO}_{2}$ concentrations on the DFs obtained in the initial two or three plates of the bubble-cap column. 
Groenier utilized the classical two-film theory in countercurrent contacting with these major assumptions: (1) $\mathrm{k}_{5}>\mathrm{k}_{3}$ so that $\mathrm{CH}_{3} \mathrm{I}$ can be ignored [Eqs. (10) and (2)]; (2) the $\mathrm{I}_{2}$-HIO equilibrium was obeyed; (3) diffusional resistance was in the liquid film only; (4) gas- and liquid-phase flow rates remained constant; and (5) absorption and reaction constants were not functions of iodine concentration. A correlation for the overall mass transfer coefficient was determined to fit the data for $\mathrm{I}_{2}$ and $\mathrm{CH}_{3} \mathrm{I}$ removal in both packed-bed and bubble-cap column Iodox operations:

$$
\mathrm{K}_{\mathrm{L}} \mathrm{a}=0.000387 \mathrm{M}^{-1 / 3} \text {, }
$$

where

$$
\begin{aligned}
& \mathrm{K}_{\mathrm{L}} \mathrm{a}=\text { overall mass transfer coefficient, overall liquid phase, } \\
& g-\operatorname{moles} /\left(\sec -\mathrm{cm}^{3}\right) \text {, } \\
& M \quad=\text { absorption factor, } M=K_{G}^{L} \frac{L_{v}}{G_{v}} \text {, and } \\
& \mathrm{L}_{\mathrm{v}}=\text { liquid volumetric flow rate, } \mathrm{cm}^{3} / \mathrm{sec} \text {, and } \\
& \mathrm{G}_{\mathrm{v}}=\text { gas volumetric flow rate, } \mathrm{cm}^{3} / \mathrm{sec} \text {. }
\end{aligned}
$$

Overall mass transfer coefficients ranged from $1.7 \times 10^{-4}$ to $3.3 \times 10^{-4}$ $\mathrm{g}$-moles $/ \mathrm{cm}^{3}-\mathrm{sec}$ in the packed column, and from $6.0 \times 10^{-4}$ to $10.2 \times 10^{-4}$ in the bubble-cap column. For operation scale-up, Eq. (11) must be utilized with the expressions derived from the two-film countercontacting model for mass transfer accompanied by a two-step chemical reaction. These expressions contain such key operating parameters as DF, M, liquid inventory in the contactor, number of transfer units, effective contacting volume, and liquid phase chemical properties. By utilizing these expressions, Groenier was able to design an Iodox unit that would 
theoretically produce a DF of $10^{5}$ for treating $2.8 \mathrm{~m}^{3} / \mathrm{min}(100 \mathrm{scfm})$ of off-gas containing $100 \mathrm{ppm}$ of either $\mathrm{I}_{2}$ or $\mathrm{CH}_{3} \mathrm{I}$. The method predicted that this DF could be obtained for a 0.508-m-ID column having about 50 bubble caps on each of ten plates (total contacting volume of 22 1iters per plate), with a $90 \% \mathrm{HNO}_{3}$ flow rate of 1.5 liters/min at room temperature.

It must again be stressed, however, that Groenier's expressions were shown to be applicable for only simple feed gases such as air containing only $\mathrm{I}_{2}$ or $\mathrm{CH}_{3} \mathrm{I}$. They were not applicable for predicting DFs for total iodine removal from feed gases containing both $\mathrm{CH}_{3} \mathrm{I}$ and $\mathrm{I}_{2}$, $\mathrm{NO}_{2}$, water, $\mathrm{CO}_{2}$, etc.

\section{1 .4 Process capacity}

The ultimate capacity of the Iodox process is limited by the solubility of iodic acid in $>20 \mathrm{M} \mathrm{HNO}_{3}:{ }^{6}$

$$
\text { In } \mathrm{S}=13.28-0.4515 \mathrm{C}_{\mathrm{HNO}_{3}}-1170 / \mathrm{T} \text {, }
$$

where

$$
\begin{aligned}
& \mathrm{S}=\text { the solubility of } \mathrm{HI}_{3} \mathrm{O}_{8} \text { in } \mathrm{g} / \text { liter, } \\
& \mathrm{T}=\text { absolute temperature, } \mathrm{K} \text {. }
\end{aligned}
$$

\subsubsection{Present process application}

An integrated Iodox system has been tested extensively by personnel in the Experimental Engineering Section of the Chemical Technology Division at ORNL. A schematic diagram of the system is shown in Fig. 1. The Iodox column is made of $0.102-\mathrm{m}-\mathrm{ID}$ glass (Pyrex) and contains eight bubblecap plates. The feed location is at the third plate from the top 


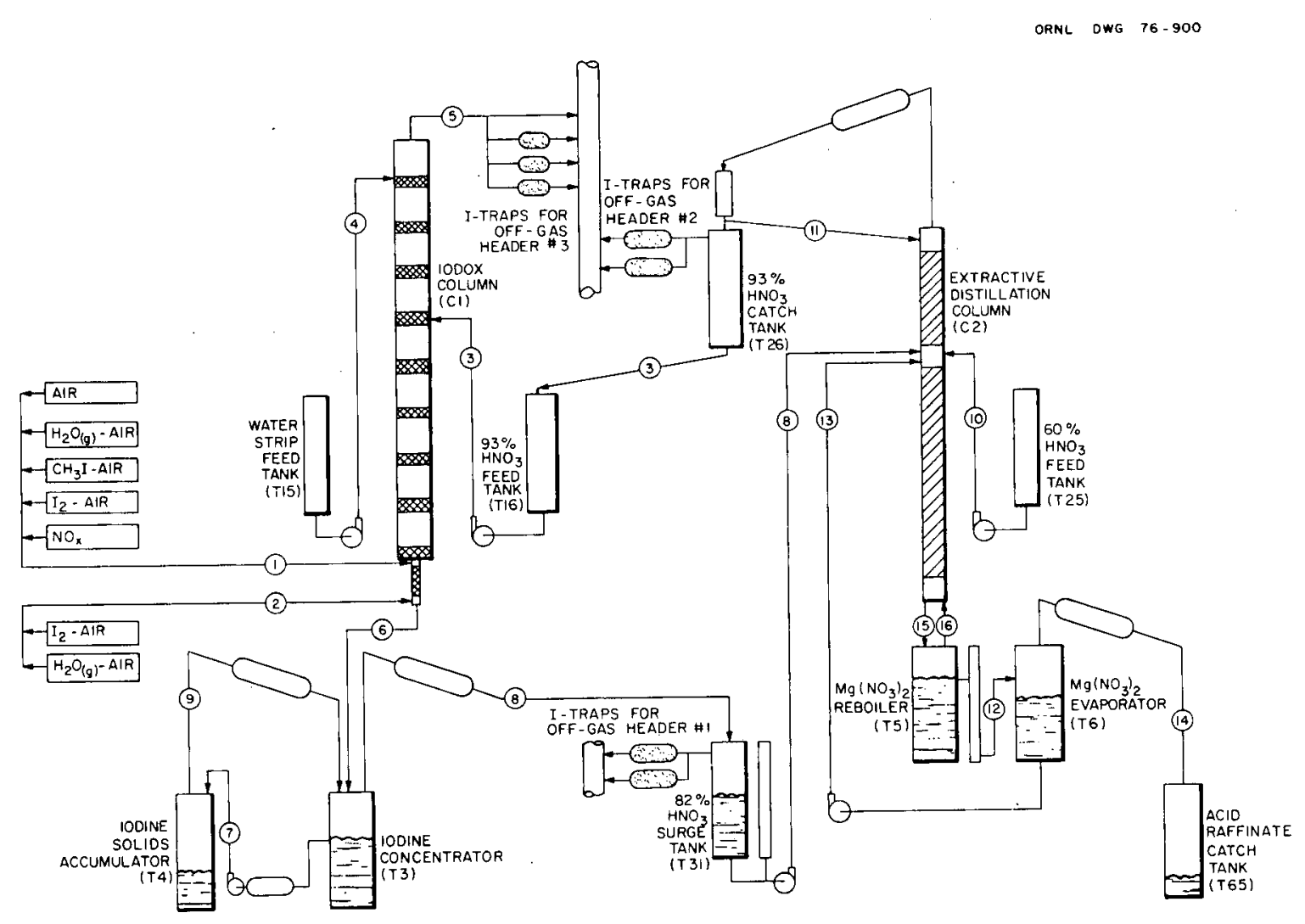

Fig. 1. Schematic diagram of process equipment in the Iodox Demonstration Facility. 
(with $>20 \mathrm{M} \mathrm{HNO}_{3}$ ), and the top two plates are normally fed with $\mathrm{H}_{2} \mathrm{O}$ to achieve acid-vapor removal from the discharged off-gas. The most realistic types of feed gases (similar to actual fuel reprocessing of $\mathrm{f}$ gases) are now being tested. These compositions include $\mathrm{NO}_{2}$ at more than $2 \%$, water vapor at $>50 \%$ relative humidity, other halides such as bromides, and sudden increases in $\mathrm{CH}_{3} \mathrm{I}$ concentration.

The $\mathrm{I}_{2}$ and $\mathrm{CH}_{3} \mathrm{I}$ concentration in feed gases to Iodox are adjusted to match those expected for actual head-end LWR and LMFBR fuel reprocessing off-gases. These are about $0.8 \times 10^{-6}$ to $1.6 \times 10^{-6}$ mole of $I_{2}$ per liter of air ( $18-$ to $36-\mathrm{ppm} \mathrm{I}_{2}$ ), and $1.0 \times 10^{-6}$ mole of $\mathrm{CH}_{3} \mathrm{I}$ per liter of air (22 ppm $\mathrm{CH}_{3} \mathrm{I}$ ). Nitric acid flow rates are in the range 0.05 to 0.10 liter/min, whereas gas feed rates are about 100 liters/min.

When $2 \% \mathrm{NO}_{2}$ was initially introduced into the feed gas, ${ }^{16}$ the DF for $\mathrm{CH}_{3} \mathrm{I}$ of the first stage (as predicted by Mailen) was drastically reduced from the range of 4 to 5 to about 1.3. Thereafter, the DF was recovered on subsequent ascending plates. The $\mathrm{DF}$ for $\mathrm{CH}_{3} \mathrm{I}$ with $2 \% \mathrm{NO}_{2}$ in the feed gas (air) was 22.7 per plate for a concentration of 20 to $20.9 \mathrm{M} \mathrm{HNO}_{3}$. Additional runs with feed gases containing $\mathrm{CH}_{3} \mathrm{I}$ in air with $2 \% \mathrm{NO}_{2}$ and $2 \% \mathrm{H}_{2} \mathrm{O}$ produced poor $\mathrm{DFs}^{17}$ at relatively low acid concentrations of 19 to $20 \mathrm{M}$. However, $\mathrm{HNO}_{3}$ concentration can be maintained in a more desirable range of 20.5 to 22.5 M by proper control of the feed acid concentration and flow rate and by careful limitation of the water feed rate to the upper portion of the column (above the acid feed plate) where nitric acid vapors are absorbed in water. ${ }^{18}$ A superior method to recover acid-vapor recovery would employ a chilled plate or condenser above the acid feed plate, followed by an external water scrubber for 
the chilled gas stream. Because it is largely absorbed on the bottom plate, water vapor entering the bottom of the Iodox column has a much less diluent effect on the scrub acid than does the acid-vapor scrub water at the top of the column.

It was demonstrated in an extended run $^{19}$ that the variation of individual plate DFs for $\mathrm{CH}_{3} \mathrm{I}$ removal with time was related to small variations in $\mathrm{HNO}_{3}$ concentration. As shown in Table 1 , the overall column DF was $4.6 \times 10^{6}$ for removing $\mathrm{CH}_{3} \mathrm{I}$ from air containing $1.9 \% \mathrm{NO}_{2}$ and $2.1 \% \mathrm{H}_{2} \mathrm{O}$; the increase in $\mathrm{DF}$ was attributed to an increased initial scrub-acid concentration of $23.4 \underline{\mathrm{M}} \mathrm{HNO}_{3}$. A1so, for removal of $\mathrm{I}_{2}$ from air containing $2 \% \mathrm{NO}_{2}$ and $2.4 \% \mathrm{H}_{2} \mathrm{O}$, the $\mathrm{DF}$ was increased to $5 \times 10^{5}$ by utilizing a scrub acid with an initial concentration of $23.5 \underline{\mathrm{M}}$.

Table 1. Iodox decontamination factors (DFs) for ${ }^{13 I}$ I-traced
$\mathrm{CH}_{3} \mathrm{I}$ in air containing $1.9 \% \mathrm{NO}_{2}-2.1 \% \mathrm{H}_{2} \mathrm{O}^{\mathrm{a}}$

Conditions: Feed rate of $23.4 \mathrm{M} \mathrm{HNO}_{3}=0.045 \mathrm{l} / \mathrm{min}$; gas feed rate $=98 \mathrm{slm} ; \mathrm{CH}_{3} \mathrm{I}$ in feed gas $=264 \mathrm{\mu g}$ I/liter $\left(47-\mathrm{ppm} \mathrm{CH}_{3} \mathrm{I}\right) ; \mathrm{T}=43^{\circ} \mathrm{C}$ plate $1,50^{\circ} \mathrm{C}$ plate 8 ; run duration, $43 \mathrm{hr}$.

\begin{tabular}{ccc}
\hline $\begin{array}{c}\text { P1ate } \\
\text { No. }\end{array}$ & $\begin{array}{c}\text { Acid concentration } \\
\text { on plate } \\
(\mathrm{M})\end{array}$ & DF \\
\hline 1 & $20.2-20.9$ & $2.94( \pm 22 \%)$ \\
2 & $20.1-22.4$ & $6.59( \pm 13 \%)$ \\
3 & $22.3-22.5$ & $7.11( \pm 13 \%)$ \\
4 & $22.3-22.6$ & $8.27( \pm 14 \%)$ \\
5 & $22.1-22.8$ & $4.37( \pm 24 \%)$ \\
6 & $22.5-22.8$ & $4.6 \times 10^{6}$ \\
\hline
\end{tabular}

a The information in this table was taken from ref. 19. $b_{\text {Based on }}{ }^{131_{I}}$ averaged samples of feed and effluent gas streams. 
An experiment in which the $\mathrm{CH}_{3} \mathrm{I}$ feed concentration was increased threefold in a step change 20 demonstrated that the Iodox process can cope with the kind of concentration changes expected for a real system where the rate of evolution of iodine from dissolver solution is known to be influenced by temperature, sparge rates, etc. ${ }^{21}$ The ability of the Iodox process to maintain satisfactory iodine trapping in the presence of a high concentration of $\mathrm{NO}_{2}$ is illustrated by the results shown in Table 2. For acid concentrations of 22.7 to $23.1 \mathrm{M}$, the deleterious effect of high- $\mathrm{NO}_{2}$ concentration was minimized beyond the second plate.

Table 2. Run IXD-13: Decontamination factors (DFs) for ${ }^{131} \mathrm{I}$-traced $\mathrm{CH}_{3} \mathrm{I}$ in air containing $7.6 \% \mathrm{NO}_{3}--1.9 \% \cdot \mathrm{H}_{2} \mathrm{O}^{\mathrm{a}}$

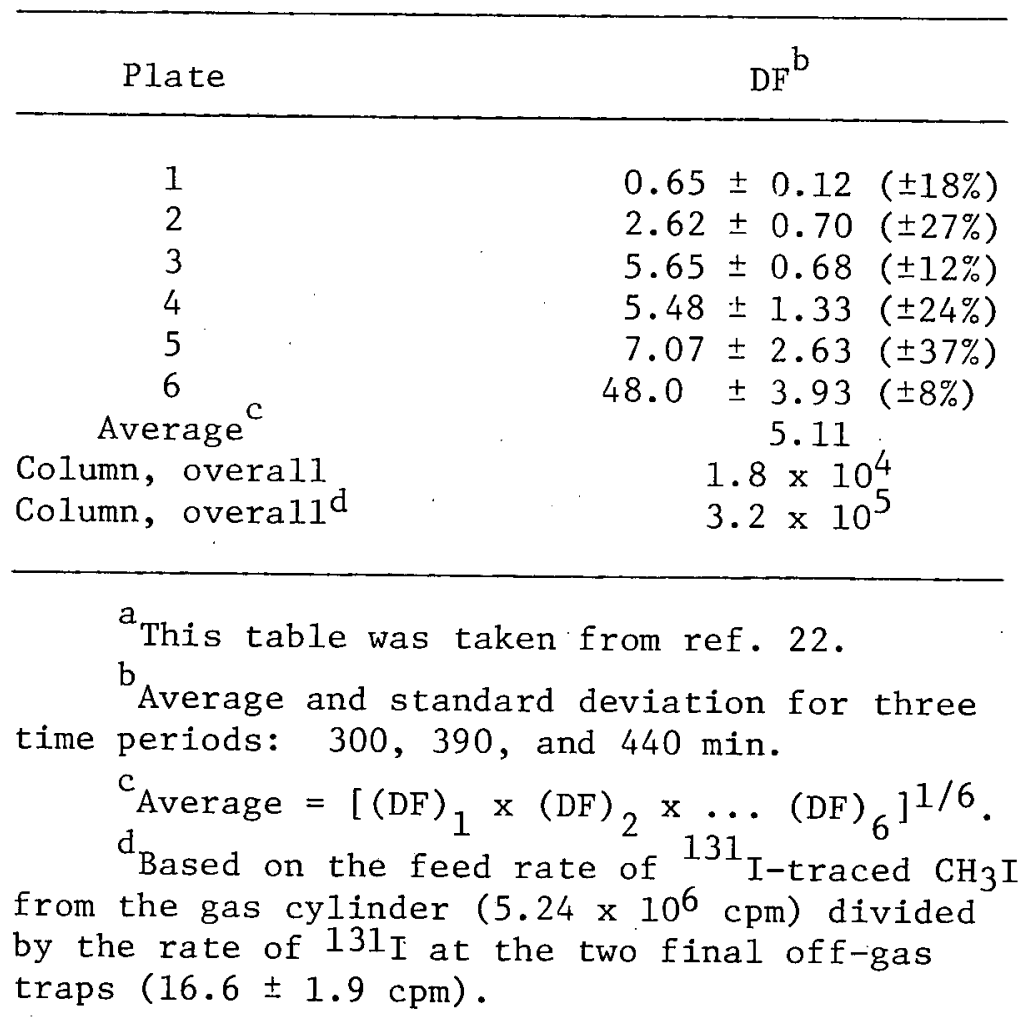


A pragmatic test of the Iodox bubble-cap column for treatment of actual off-gas from dissolution of nuclear fuel pins has recently been conducted at the Transuranium Processing Facility (TRU) at ORNL. ${ }^{21}$ (The remaining three operations in the Iodox process were not utilized in these tests.) The Iodox column was employed as the primary equipment for removing iodine from off-gas produced during dissolution of irradiated TRU curium targets. There was close similarity between the concentrations of fission products in this dissolver solution and the concentrations calculated for spent Fast-Flux Test Facility (FFTF) fuel that was irradiated to 45,000 MWd/ton, cooled 30 days, and dissolved to $100 \mathrm{~g}$ per liter of heavy metal.

The conditions of the Iodox column tests were as follows:

1. Iodox column, $7.62 \mathrm{~cm}$ ID; six bubble-cap plates, spaced $20.3 \mathrm{~cm}$ apart; three bubble caps on each plate;

2. 21 to 23 는 $\mathrm{HNO}_{3}$;

3. gas flow rate about $7 \mathrm{~s} 1 \mathrm{~m}(1.55 \mathrm{~m} / \mathrm{min})$;

4. liquid flow rate, 250 to $420 \mathrm{ml} / \mathrm{hr}(5.5$ to $9.3 \mathrm{~cm} / \mathrm{hr})$;

5. column operated in a cell at $40^{\circ} \mathrm{C}$. The composition of the off-gas from the dissolver was dependent on the various modes of sparging utilized during four separate tests. However, the off-gas generally contained iodine, $\mathrm{N}_{2}, \mathrm{O}_{2}\left(\mathrm{~N}_{2}\right.$ and $\mathrm{O}_{2}$ from air sparge), and such fission products as the noble gases xenon and krypton, and other gases such as trace carbon dioxide from the air sparge, and NO ${ }_{x}$ 's arising from $\mathrm{HNO}_{3}$ dissolution. The concentration of the other off-gas components was not established, but their presence served to authenticate the off-gas as a reasonable facsimile of a gas that would arise in processing spent fuels from the Fast-Flux Test Facility. 
Although the evolution of the iodine from the dissolver varied according to the various sparging schedules, the Iodox column, for the operating conditions, column design, and off-gas composition as discussed, produced DFs for iodine from $1.2 \times 10^{4}$ to $8.0 \times 10^{4}$ (or 5 to 7 per stage). Virtually all of the iodine may be assumed to be in an inorganic state, because there were no probable sources for the formation of organic iodide. Feed concentrations were of high ${ }^{131}$ I activity but relatively low overall iodine concentrations, or about $0.1 \mathrm{Ci}^{131}$ I/1iter for $30 \mathrm{hr}$ of averaged column operation time.

\subsubsection{Process advantages}

1. The Iodox process can be operated to tolerate feed gases at their dew point by proper location of the feed plate and utilization of very high scrub acid molarities (>22 $\underline{\mathrm{M}}$ ).

2. Nitrogen oxide $\left(2 \% \mathrm{NO}_{2}\right.$ level) can be tolerated in the process, although there is some reduction in the DF on the first one or two plates. DFs are satisfactory even at high ( $8 \%) \mathrm{NO}_{2}$ concentrations.

3. In the Iodox process, high DFs $\left(>10^{4}\right)$ for feed gases containing either $\mathrm{I}_{2}$ or $\mathrm{CH}_{3} \mathrm{I}$ can thus be obtained in the presence of $\mathrm{NO}_{2}$ and $\mathrm{H}_{2} \mathrm{O}$.

4. No new chemicals are introduced into the fuel reprocessing plant.

5. Reaction rates and DFs appear to be enhanced by higher off-gas temperatures. 
6. The product from Iodox is essentially $100 \% \mathrm{HI}_{3} \mathrm{O}_{8}$. Iodine as iodic acid is not in an acceptable form for long-term storage. The leaching characteristics of radioiodine, which is included as insoluble $\mathrm{Ba}\left(\mathrm{IO}_{3}\right)_{2}$ in Portland cement, have been described. ${ }^{23}$ Iodic acid, $\mathrm{HIO}_{3}$ (the behavior of $\mathrm{HI}_{3} \mathrm{O}_{8}$ was equivalent to that of $\mathrm{HIO}_{3}$ ), was reacted with aqueous barium hydroxide $\left[\mathrm{Ba}(\mathrm{OH})_{2}\right]$ supplied so that the slurry was always alkaline, to produce $\mathrm{Ba}\left(\mathrm{IO}_{3}\right)_{2}$. Specimens containing from 5.4 to 11.9 wt \% iodine as $\mathrm{Ba}\left(\mathrm{IO}_{3}\right)_{2}$ showed incremental leaching rates of $\sim 3 \mu \mathrm{m} /$ day after 100 days of leaching according to standard leaching procedures. It was estimated that the fission product iodine after one year of decay would consist of $75 \%{ }^{129} \mathrm{I}--25 \%{ }^{127} \mathrm{I}$. $\mathrm{A} \mathrm{Ba}\left(\mathrm{IO}_{3}\right)_{2}$-Type 1cement product containing $9.05 \%$ of this fission product iodine generated about $3.0 \mu \mathrm{W}$ per $\mathrm{kg}$ of product. Both the leach rates and quantities of heat generated by fission product decay are acceptable for storage of the $\mathrm{Ba}\left(\mathrm{IO}_{3}\right)_{2}^{-}$ cement preparation in presently specified repositories. The calculation of storage space for the $\mathrm{Ba}\left(\mathrm{IO}_{3}\right)_{2}$-cement product was based ${ }^{23}$ on an LMFBR fuel reprocessing plant handling $5 \mathrm{MTHM} / \mathrm{day}$, which would produce $\sim 1.6 \mathrm{~kg}$ of iodine per day. This amount of iodine could be incorporated into $9.5 \times 10^{-3} \mathrm{~m}^{3}\left(2.85 \mathrm{~m}^{3} /\right.$ year $)$ of concrete containing 9.05 wt \% iodine.

7. The integrated Iodox system has been tested for a scale of equipment design which was of sufficient magnitude to 
minimize difficulties in scale-up of the process to pilot plant or full-size plant magnitude. Runs have been completed with the Iodox integrated system in which it has been shown that all of the unit operations function as expected. The product, as a dehydrated form of $\mathrm{HI}_{3} \mathrm{O}_{8}$, has been shown to be amenable to reaction with $\mathrm{Ba}(\mathrm{OH})_{2}$ to produce a solid that appears very promising as a candidate for long-term storage after incorporation in concrete.

\subsubsection{Process disadvantages}

The Iodox process has been compared ${ }^{24}$ to the Allied Chemical INEL process for iodine sorption on tandem beds of silver-exchanged and lead-exchanged mordenites, with subsequent regeneration of the first bed (see Sect. 3.4 for a description of this process, which is still under development). Following are some of the operational limitations that have been interpreted as disadvantages for the Iodox system, with comments in brackets:

1. If $\mathrm{NO}_{\mathrm{x}}$ scrubbing is conducted prior to Iodox, corrosion effects are associated with iodine in the scrubber acid. Hazards are also associated with holding large amounts of iodine in DOG scrubber bottoms in an easily volatilized form. [An Iodox experiment with $\sim 8 \% \mathrm{NO}_{2}$ in the feed gas has indicated that $\mathrm{NO}_{\mathrm{x}}$ scrubbing prior to Iodox may possibly be eliminated. ${ }^{22}$ ]

2. If fluorides are introduced into the fuel reprocessing flowsheet (e.g., in processing denatured thorium-uranium fuel in the Zirflex process), serious corrosion could be 
introduced by fluoride-zirconium - boiling nitric acid.

3. The Iodox system involves a fairly complex set of processes requiring extensive instrumentation and flow control. [Recent experience with the removal of iodine from dissolver off-gas from curium targets ${ }^{21}$ showed that control of Iodox was straightforward, and that acceptable iodine DFs could be retained for excursions of iodine feed concentration and off-gas flow rate. ${ }^{25}$ ]

4. With its three major operations (tower, iodine accumulatorreboiler, and salt extraction distillation), Iodox could well-entail high capital costs.

5. Operation of Iodox would require internal plant production of hyperazeotropic $\mathrm{HNO}_{3}$.

6. There is a possibility of accumulating explosive nitrates in Iodox scrubber bottoms and condensates. Hyperazeotropic $\mathrm{HNO}_{3}$ is an excellent nitrating solution, so that care must be exercised to prevent $\mathrm{CH}_{3} \mathrm{NO}_{3}$ (and other organic nitrates, especially aromatic nitrates) from accumulating in the condenser. [The formation of $\mathrm{CH}_{3} \mathrm{NO}_{3}$ has not been yet identified as detrimental to the Iodox process. ${ }^{25}$ ]

\subsection{Mercuric Nitrate--Nitric Acid Scrubbers}

\subsubsection{Background}

One of the early processes developed for iodine species removal from fuel reprocessing off-gases was the mercuric nitrate--nitric acid 
$\left[\mathrm{Hg}\left(\mathrm{NO}_{3}\right)_{2}-\mathrm{HNO}_{3}\right]$ scrubbing process in packed or bubble-cap columns featuring complete mercury recycle. This process was shown to be applicable for removal of both organic and inorganic iodides from recirculated LWR-LMFBR fuel reprocessing off-gases. When adequate residence time is provided to decompose the organic iodides in the feed gas, the overall efficiency of the process is controlled by the extent of bleed-off of accumulated iodine from the recycle solution.

\subsubsection{Chemical mechanisms}

The reaction between $\mathrm{I}_{2}$ in air and a solution of $\mathrm{Hg}\left(\mathrm{NO}_{3}\right)_{2}$ in subazeotropic $\mathrm{HNO}_{3}$ was: 26

$$
6 \mathrm{I}_{2}+6 \mathrm{Hg}\left(\mathrm{NO}_{3}\right)_{2}+6 \mathrm{H}_{2} \mathrm{O} \rightarrow 5 \mathrm{HgI}_{2}+\mathrm{Hg}\left(\mathrm{IO}_{3}\right)_{2}+12 \mathrm{HNO}_{3}
$$

however, the rate for reaction (13) was not established experimentally because the rate-controlling step for $\mathrm{Hg}\left(\mathrm{NO}_{3}\right)_{2}$ scrubbing of feed gases containing both $\mathrm{I}_{2}$ and $\mathrm{CH}_{3} \mathrm{I}$ occurred in the $\mathrm{CH}_{3} \mathrm{I}-\mathrm{Hg}\left(\mathrm{NO}_{3}\right)_{2}$ reaction. Due to the low solubility of mercuric iodate $\left[\mathrm{Hg}\left(\mathrm{IO}_{3}\right)_{2}\right]$ in $\mathrm{HNO}_{3}$, it would be preferable to operate the process to minimize the formation of iodate that was shown in reaction (13). This formation can be prevented by inclusion of nitrite in the $\mathrm{Hg}\left(\mathrm{NO}_{3}\right)_{2}-\mathrm{HNO}_{3}$ scrub solution. It was speculated ${ }^{5}$ that the stoichiometry of the reaction between $\mathrm{CH}_{3} \mathrm{I}$ and $\mathrm{Hg}\left(\mathrm{NO}_{3}\right)_{2}-\mathrm{HNO}_{3}$ solution could be either:

$$
\left.\mathrm{CH}_{3} \mathrm{I}+\frac{1}{2} \mathrm{Hg}_{\left(\mathrm{NO}_{3}\right.}\right)_{2} \rightarrow \frac{1}{2} \mathrm{HgI}_{2}+\mathrm{CH}_{3} \mathrm{NO}_{3}
$$

or

$$
\mathrm{CH}_{3} \mathrm{I}+\frac{1}{2} \mathrm{Hg}\left(\mathrm{NO}_{3}\right)_{2}+\mathrm{H}_{2} \mathrm{O} \rightarrow \frac{1}{2} \mathrm{HgI}_{2}+\mathrm{CH}_{3} \mathrm{OH}+\mathrm{HNO}_{3} \text {. }
$$


The kinetics of the $\mathrm{CH}_{3} \mathrm{I}-\mathrm{Hg}\left(\mathrm{NO}_{3}\right)_{2}$ reaction could be represented by a pseudo-first-order reaction. ${ }^{27,28}$ The pseudo-first-order reaction-rate constant was $0.44 \mathrm{~min}^{-1}$, and the $\mathrm{CH}_{3} \mathrm{I}$ half-life was $1.6 \mathrm{~min}$ at $30^{\circ} \mathrm{C}$ for a $\mathrm{CH}_{3} \mathrm{I}$ concentration of $1.6 \times 10^{-6} \underline{\mathrm{M}}$ and $7.9 \times 10^{-6} \underline{\mathrm{M}}$. The reaction rates between $\mathrm{CH}_{3} \mathrm{I}$ and very low $\mathrm{Hg}\left(\mathrm{NO}_{3}\right)_{2}-\mathrm{HNO}_{3}$ concentrations were measured 29 and found to be proportional to both $\mathrm{Hg}\left(\mathrm{NO}_{3}\right)_{2}$ and $\mathrm{HNO}_{3}$ concentrations. There were indications that the rate could be increased by a factor of 100 by increasing the $\mathrm{HNO}_{3}$ concentration from 0.2 to 12 to $13 \underline{\mathrm{M}}$.

An expression was developed ${ }^{30}$ to describe the scrubbing efficiency of $\mathrm{Hg}\left(\mathrm{NO}_{3}\right)_{2}-\mathrm{HNO}_{3}$ solutions for removal of $\mathrm{CH}_{3} \mathrm{I}$ from air in a single stage. The main assumptions were: (1) the reaction to form $\mathrm{HgI}^{+}$ (following gas to liquid distribution) was irreversible, slow, and the rate-controlling step; (2) there was perfect mixing on the stage; (3) there were no diffusion limitations. The resultant expression was

$$
D F=\frac{L_{v}}{G_{v}} D_{G}^{L}+\frac{V_{L H}}{G_{v}} D_{G}^{L} \frac{(0.693)}{t_{1 / 2}}+1,
$$

where

$$
\begin{aligned}
\mathrm{D}_{\mathrm{G}}^{\mathrm{L}}= & \text { liquid-vapor distribution coefficient for } \mathrm{CH}_{3} \mathrm{I} \text {, with a } \\
& \text { value of } 4 \text { to } 8 \text { as } \mathrm{HNO}_{3} \text { molarity increases from } 0 \text { to } 12 \mathrm{M} ; \\
\mathrm{V}_{\mathrm{LH}}= & \text { liquid holdup, } \mathrm{cm}^{3} ; \\
\mathrm{L}_{\mathrm{V}}, \mathrm{G}_{\mathrm{V}}= & \text { same as } \mathrm{Eq} .(11) ; \\
\mathrm{t}_{1 / 2}= & \text { half-life for fixation reaction, sec. }
\end{aligned}
$$

This equation can be used to estimate DFs for the $\mathrm{CH}_{3} \mathrm{I}-\left[\mathrm{Hg}\left(\mathrm{NO}_{3}\right)_{2}-\mathrm{HNO}_{3}\right]$ reaction in bubble-cap columns when appropriate stage efficiencies are available. 


\subsubsection{Experimental results and engineering data useful for process design}

Initial studies of $\mathrm{Hg}\left(\mathrm{NO}_{3}\right)_{2}-\mathrm{HNO}_{3}$ scrubbing of iodine. Initial studies for simple bubble-column operation indicated that large DFs could be obtained for $\mathrm{CH}_{3} \mathrm{I}$ removal from air with $\mathrm{Hg}\left(\mathrm{NO}_{3}\right)_{2}-\mathrm{HNO}_{3}$ solutions. So that large DFs $\left(>10^{3}\right)$ could be maintained for $\mathrm{CH}_{3} \mathrm{I}$ scrubbing in packed columns, it was necessary to: (1) utilize porous packing to maximize liquid holdup, ${ }^{31}$ (2) greatly increase the $\mathrm{HNO}_{3}$ concentration (from $0.1 \underline{\mathrm{M}}$ to 8 to $15 \underline{\mathrm{M}}),{ }^{29}$ and (3) reduce iodine bleed-off from the recirculating scrub. This reduction was achieved to some extent by the addition of an iodine recovery loop to the process. ${ }^{29}$ The recovery loop was based on a reflux condenser, which allowed iodide to be recovered as mercuric iodate ${ }^{32}$ while the supernatant and the distillate were being recycled.

$\underline{\mathrm{Hg}}\left(\mathrm{NO}_{3}\right)_{2}-{ }_{-\mathrm{HNO}}$ scrubbing in packed columns. When $\mathrm{CH}_{3} \mathrm{I}$ and $\mathrm{I}_{2}$ were scrubbed from air in 2.54-cm-ID packed columns with $0.2 \mathrm{M} \mathrm{Hg}\left(\mathrm{NO}_{3}\right)_{2}^{--}$ 14 to $15 \mathrm{M}^{\mathrm{HNO}}{ }_{3}$ solutions with continuous iodate recovery and recycle for part of the scrub solution, $D F s \geq 10^{4}$ were obtained for 5 to $10 \mathrm{slm}$. 33,* The utilization of a second column in series with the first column increased the DF no more than an order of magnitude. The DF decreased when the operating temperature was increased from 40 to $80^{\circ} \mathrm{C}$. The DFs obtained for $\mathrm{CH}_{3} \mathrm{I}$ removal in a $0.4 \underline{\mathrm{M}} \mathrm{Hg}\left(\mathrm{NO}_{3}\right)_{2}^{--8} \underline{\mathrm{M}} \mathrm{HNO}_{3}$ solution in a packed column decreased from $10^{5}$ to $10^{2}$ as the gas flow was increased from 2.5 to $9.5 \mathrm{slm}$. 34 Best DFs for $\mathrm{CH}_{3} \mathrm{I}$ were obtained with a mercury concentration of $0.4 \mathrm{M}^{35}$ Removal of organic contaminants from the mercury scrub solutions prior to application to the column resulted in

For the studies with $\mathrm{Hg}\left(\mathrm{NO}_{3}\right)_{2}-\mathrm{HNO}_{3}$ scrubbing solutions, s1m was for $1 \mathrm{~atm}$ and $25^{\circ} \mathrm{C}$. 
only marginal improvement in the column performance. 36,37 The DF for $I_{2}$ was much less affected by gas flow rate than was the $\mathrm{DF}$ for $\mathrm{CH}_{3} \mathrm{I}$. In tests with $\mathrm{I}_{2}$-containing feed gases, the DF decreased by a factor of on1y 8 (the DF for $\mathrm{CH}_{3} \mathrm{I}$ was reduced by $10^{3}$ ) when the air flow was increased from 2.5 to $9.5 \mathrm{~s} 1 \mathrm{~m} .{ }^{37}$ A schematic of the $\mathrm{Hg}\left(\mathrm{NO}_{3}\right)_{2}-\mathrm{HNO}_{3}$ scrubbing process as conducted with the packed column is shown in Fig. 2 . $\underline{\mathrm{Hg}}_{\left(\mathrm{NO}_{3}\right)}{ }_{2}-\mathrm{HNO}_{3}$ scrubbing in bubble-cap columns. In studies of simulated bubble-cap columns $(2.54 \mathrm{~cm}$ ID with up to eight stages, 15.2 $\mathrm{cm} /$ stage), DFs for $\mathrm{CH}_{3} \mathrm{I}$ removal in $0.4 \underline{\mathrm{Mg}} \mathrm{Hg}\left(\mathrm{NO}_{3}\right)_{2}^{--10} \underline{\mathrm{M}} \mathrm{HNO}_{3}$ were very similar to those obtained in packed beds. When the diameter of the bubble-cap column was increased from 2.54 to $4.06 \mathrm{~cm}, 37$ there was an improvement in the $\mathrm{DF}$. The $\mathrm{DF}$ for $\mathrm{CH}_{3} \mathrm{I}$ again varied inversely with gas velocity, decreasing from 4.4 per stage at 3.31 iters $/ \mathrm{min}$ to 3.25 per stage at 5.3 liters/min. ${ }^{38}$ In addition, the simultaneous removal of $\mathrm{I}_{2}$ and $\mathrm{CH}_{3} \mathrm{I}$ from air was studied in bubble-cap columns for feed concentrations of about 50-ppm I $\left(500\right.$ to $600 \mathrm{mg} \mathrm{I}_{2} / \mathrm{m}^{3}$ ) and $6-\mathrm{ppm} \mathrm{CH}_{3} \mathrm{I}$ (40 mg $\left.\mathrm{CH}_{3} \mathrm{I} / \mathrm{m}^{3}\right)$. Overal1 DFs were about $5 \times 10^{4}$ for both $\mathrm{CH}_{3} \mathrm{I}$ and $\mathrm{I}_{2}$ in a 2.54-cm-ID eight-stage bubble-cap column. The addition of $\mathrm{N}_{2} \mathrm{O}_{3}$, octane, and dodecane contaminants to the gas feed had little effect on the DF. However, when aromatics (xylene, diethylbenzene) were added to the feed gas, the DF was decreased by 2 to 3 orders of magnitude. The DF for trapping pheny 1 iodide was at least 2 orders of magnitude less than the $\mathrm{DF}$ for $\mathrm{CH}_{3} \mathrm{I}$. Other alkyl iodides were absorbed with efficiencies similar to that for $\mathrm{CH}_{3} \mathrm{I}^{38}$

A study ${ }^{39}$ was conducted to ascertain the capability of the bubblecap operation (1) to treat feed gases similar to fuel reprocessing 
ORNL DWG. $72-67 R 4$

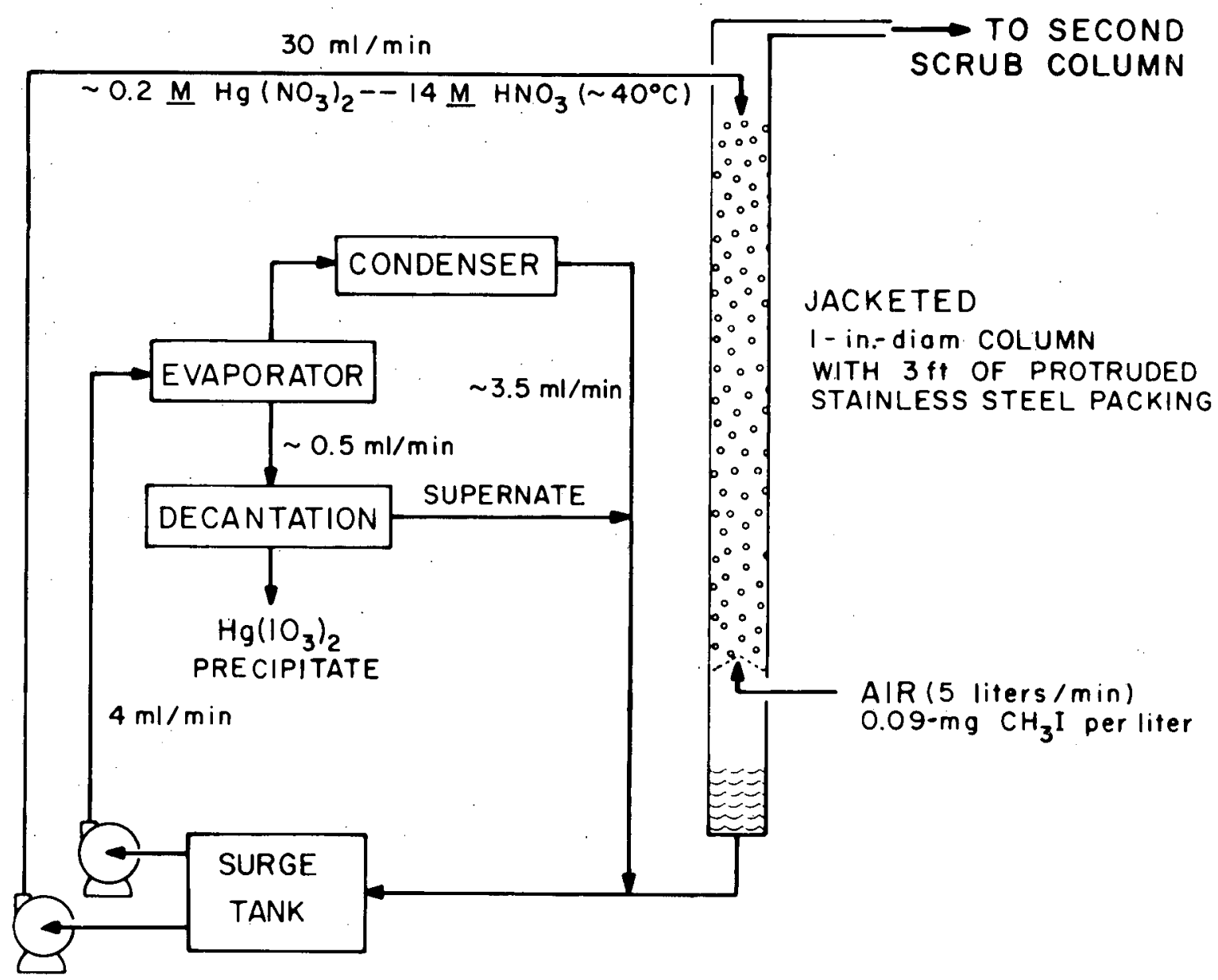

Fig. 2. Schematic of equipment for scrubbing methyl iodide from air with $0.2 \underline{\mathrm{M}} \mathrm{Hg}\left(\mathrm{NO}_{3}\right) 2^{--14} \underline{\mathrm{M}} \mathrm{HNO}_{3}$ in a packed column. 
head-end off-gases $\left(I_{2}\right.$ at $50 \mathrm{ppm}$ ), and (2) to treat feeds that would simulate effluent streams which were products from primary iodine treatment or were off-gases from vessel and process off-gas bleeds (0.05-ppm $I_{2}$ ). The DFs for $I_{2}$ removal showed a slight dependence on $I_{2}$ feed gas concentration, with a reduction in DF of one order when the $\mathrm{I}_{2}$ concentration was decreased by 3 orders of magnitude. Decontamination factors of about $10^{3}$ to $10^{4}$ were obtained for $\mathrm{I}_{2}$ removal from air (at $0.05-\mathrm{ppm} \mathrm{I}_{2}$ ) with $\mathrm{Hg}\left(\mathrm{NO}_{3}\right)_{2}-\mathrm{HNO}_{3}$ scrubbing for a wide range of iodine concentrations in the scrub liquor, which varied from $0.01-$ to $8-\mathrm{g} \mathrm{I}^{-} / 1$ iter. In summary, a fairly constant $D F$ for $I_{2}$ scrubbing was maintained in both bubble-cap 38,39 and packed columns $31,33,34,37$ for variations of gas residence time, column geometry and packing material, concentrations of $\mathrm{Hg}\left(\mathrm{NO}_{3}\right)_{2}$ and $\mathrm{HNO}_{3}$, and $\mathrm{I}_{2}$ feed concentration. This behavior seemed to indicate that the DF for $\mathrm{I}_{2}$ during $\mathrm{Hg}\left(\mathrm{NO}_{3}\right)_{2}-\mathrm{HNO}_{3}$ scrubbing was controlled primarily by bleed-off of iodine from the circulating solution in the form of relatively stable organic iodides (produced by the reaction of iodine with organic impurities in the solution).

Correlations useful for engineering scale-up. The DFs for $\mathrm{CH}_{3} \mathrm{I}$. and $\mathrm{I}_{2}$ at low flow rates were similar for bubble-cap scrubbing. 38 However, the DF for $\mathrm{I}_{2}$ showed very little change when the operating parameters were varied. Conversely, the $\mathrm{DF}$ for $\mathrm{CH}_{3} \mathrm{I}$ in both bubblecap $^{37,38}$ and packed-bed operations $31-36,39$ could be correlated with such parameters as $\mathrm{Hg}\left(\mathrm{NO}_{3}\right)_{2}$ concentration, $\mathrm{HNO}_{3}$ concentration, gas residence time, and type of packing. A useful correlation for the parameter ranges outlined above was developed: 5

$$
\text { In } D F=\left(\frac{\tau}{A}\right) \exp \left(-0.282+0.288 \mathrm{C}_{\mathrm{HNO}_{3}}+4.54 \mathrm{C}_{\mathrm{Hg}}\right) \text {; }
$$


for a $\mathrm{DF} \leq 10^{3}$. However, for a $\mathrm{DF} \geq 10^{3}$, the expression was:

$$
\operatorname{ln~DF}=1.893+\left(\frac{\tau}{\mathrm{A}}\right) \exp \left(-0.62+0.288 \mathrm{C}_{\mathrm{HNO}_{3}}+4.54 \mathrm{C}_{\mathrm{Hg}}\right) ;
$$

where $\tau$ is the gas residence time (min), $\mathrm{C}_{\mathrm{HNO}_{3}}$ is $\mathrm{HNO}_{3}$ molarity, $\mathrm{C}_{\mathrm{Hg}}$ is $\mathrm{Hg}\left(\mathrm{NO}_{3}\right)_{2}$ molarity, and $\mathrm{A}$ is a column packing parameter. The ranges of variables for which the two empirical correlations produced useful predictions for acid recycle operation are:

$\begin{array}{ll}\mathrm{DF} & 1 \text { to } 10^{5} \\ \tau & 0.02 \text { to } 0.34 \\ \mathrm{C}_{\mathrm{HNO}_{3}} & 0.005 \text { to } 14 \\ \mathrm{C}_{\mathrm{Hg}} & 0.005 \text { to } 0.4\end{array}$

\section{2 .4 Process capacity}

The capacity of the $\mathrm{Hg}\left(\mathrm{NO}_{3}\right)_{2}-\mathrm{HNO}_{3}$ scrubbing process is determined by the need to maintain a mercury to iodine ratio of about 4 to prevent

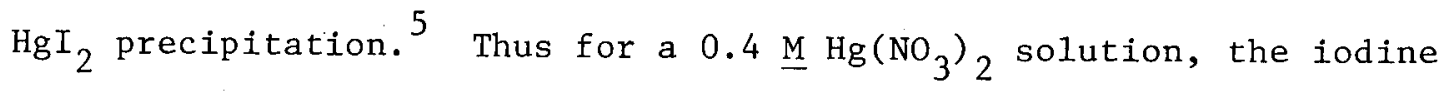
concentration can be no higher than $12.75-\mathrm{g} \mathrm{I}_{2} /$ liter. The presence of nitrite in the scrub solution prevents formation of iodate precipitates at conditions of low operating temperatures and high $\mathrm{HNO}_{3}$ concentrations. In actual plant operation, the presence of $\mathrm{NO}_{\mathrm{x}}$ in the off-gas will result in production of $\mathrm{HNO}_{2}$ (nitrous acid) and, thus, prevention of iodate formation.

\subsubsection{Current process application}

The $\mathrm{Hg}\left(\mathrm{NO}_{3}\right)_{2}-\mathrm{HNO}_{3}$ scrubber process has been used in series with other processes such as caustic scrubbing and charcoal sorption to remove 
iodine species from dissolver off-gases (e.g., the TRU Facility at ORNL ${ }^{40,41}$ ). Practical operating DFs of $10^{2}$ were obtained with the mercury scrubber. The $\mathrm{Hg}\left(\mathrm{NO}_{3}\right)_{2}-\mathrm{HNO}_{3}$ scrubbing system was installed in the full-scale LWR fuel reprocessing plant constructed by AGNS at Barnwe11, South Carolina. A plant DF of 10 for ${ }^{129} \mathrm{I}$ and ${ }^{131} \mathrm{I}$ is claimed when mercury recycle and iodine isolation by evaporation and condensation are not used; if iodine volatilization and recovery as a solid condensate are used, a DF of 75 would be claimed. ${ }^{3}$ In general, bleed-off in the recirculating scrub of previously sorbed iodine will probably limit the effective overall iodine DF to about $10^{2}$ for acid recycle operation; the iodine loading of the waste scrub mercury solution is about 1 mole of $\mathrm{I}^{-}$per 4 moles of $\mathrm{Hg}$. The effluent stream from a $\mathrm{Hg}\left(\mathrm{NO}_{3}\right)_{2}$ scrubber in a $5 \mathrm{MTHM} /$ day fuel reprocessing plant might typically consist of 100 liters/day of $8 \mathrm{M} \mathrm{HNO}_{3}$ and $0.4 \mathrm{M} \mathrm{Hg}\left(\mathrm{NO}_{3}\right)_{2}$ containing $1300 \mathrm{~g}$ of $\mathrm{I}_{2}$. If not recycled, this would amount to $30 \mathrm{~m}^{3}$ of liquid wastes per year. Thus an obvious alteration that could improve the process would be the development of complete recycle of the mercury. ${ }^{42}$ It has recently been shown in bench-scale studies ${ }^{43}$ that the mercury in the $\mathrm{Hg}\left(\mathrm{NO}_{3}\right)_{2}-\mathrm{HNO}_{3}$ scrubbing process can be recycled. The mercuric iodate product $\left[\mathrm{Hg}\left(\mathrm{IO}_{3}\right)_{2}\right]$ was contacted with $\mathrm{NaOH}$ to yield $\mathrm{HgO}$ and $\mathrm{NaIO}_{3}$. The HgO could then be recycled with $\mathrm{HNO}_{3}$, while the $\mathrm{NaIO}_{3}$ was reacted with $\mathrm{Ba}(\mathrm{OH})_{2}$ to recover iodine as $\mathrm{Ba}\left(\mathrm{IO}_{3}\right)_{2}$. The $\mathrm{Ba}\left(\mathrm{IO}_{3}\right)_{2}$ was cast into a Type-I concrete which was 15 wt \% iodine as barium iodate.

\section{2 .6 Process advantages}

1. Both $\mathrm{I}_{2}$ and $\mathrm{CH}_{3} \mathrm{I}$ can be removed simultaneously from off-gases, with appreciable DFs, by utilizing $\mathrm{Hg}\left(\mathrm{NO}_{3}\right)_{2}-\mathrm{HNO}_{3}$ scrubbing. 
2. The removal of $\mathrm{I}_{2}$ and $\mathrm{CH}_{3} \mathrm{I}$ is relatively unaffected by other alkyl iodides and such trace organic contaminants as octane and dodecane in the feed gas.

3. The removal of iodide species would probably be affected very little by water vapor up to $100 \%$ humidity.

4. The $\mathrm{Hg}\left(\mathrm{NO}_{3}\right)_{2}-\mathrm{HNO}_{3}$ scrubbing process actually benefits from the presence of $\mathrm{NO}_{2}$ in the feed gas, since it acts to prevent formation of insoluble $\mathrm{Hg}\left(\mathrm{IO}_{3}\right)_{2}$.

5. The contactor can be constructed from stainless steel.

\subsubsection{Process disadvantages}

1. Further studies are required to optimize conversion of the mercury-iodide species to a suitable disposal form, which would simultaneously provide recycle of the bulk of the $\mathrm{Hg}\left(\mathrm{NO}_{3}\right)_{2}-\mathrm{HNO}_{3}$ solution back to the process.

2. Considerable reduction in DF occurs as a result of high iodine bleed-off at high iodine-to-mercury ratios in the scrub solution.

3. No test results have been obtained for full-scale process columns. Additional tests of the process in engineering equipment would be desirable to further substantiate the process efficiency and to provide better scale-up information.

4. Perhaps the most serious diminution of process DF occurs if aromatics are present in the feed gas. 
3. THE REMOVAL OF IODINE SPECIES FROM OFF-GASES BY UTILIZING SOLID SORBENTS

The nitric acid scrubbing methods previously discussed have been proposed primarily for removing iodine species from off-gases produced in large-scale fuel reprocessing plants. These acid scrub methods could also be utilized in smaller-scale nuclear operations [e.g., the cleaning of ventilation air and off-gases from such experimental facilities as the ORNL High-Flux Isotope Reactor (HFIR) operation or the TRU Facility]. However, solid sorbent beds have been proposed as alternatives to the acid scrub operations, because solid sorbents may be inherently less complicated, less expensive, and less affected by process equipment failures than are the wet scrub operations. Among the solid sorbents that have been used or show promise in the processing of nuclear powerassociated off-gases are: (1) charcoal for controlling iodine removal from air and gas cleaning systems in experimental nuclear facilities and commercial nuclear power plants; (2) silver-exchanged zeolites for polishing effluents from primary iodine removal processes in fuel reprocessing plants; (3) silver- and lead-exchanged mordenites for direct treatment of fuel reprocessing head-end dissolver off-gas; and (4) macroreticular resins for polishing dilute-in-iodine off-gases that could be produced during volatilization of low-level liquid radwastes from fuel reprocessing.

Four measures of performance are normally used to determine the capability of a solid sorbent to remove iodine species from off-gases. These include sorbent loading capacity and three definitions for the fraction of iodine removed from the feed gas: penetration, efficiency, 
and decontamination factor (DF). The latter three factors are related as follows:

Penetration $=1$-efficiency
Decontamination factor $=\frac{1}{1-e f f i c i e n c y}=\frac{1}{\text { penetration }}$.

The most-often utilized measure of removal performance is the DF. It is defined as the moles of an iodine compound in the feed gas divided by the moles of the same iodine compound in the effluent gas. The DF is normally measured by utilizing a highly radioactive iodine isotope, because removal efficiencies are usually so large that nonradiotracer methods do not provide the required sensitivity to detect low levels of iodine. The most-often used radioiodine isotopes are ${ }^{131} \mathrm{I}$ with a half-1ife of 8.06 days, and ${ }^{130} \mathrm{I}$ with a half-Iife of $12.4 \mathrm{hr}$. Along with a measure of the fraction of the iodine that is removed from the feed gas, it is necessary to specify the quantity of iodine that can be loaded on the sorbent of interest while maintaining the fractional removal. The loading capacity is generally expressed as either milligrams of iodine sorbed per gram or per cubic centimeter of sorbent.

\subsection{Removal of Iodine Species from Nuclear Reactor Operation} Off-Gases by Utilizing Activated Charcoal

\subsubsection{Background}

For large gas-flow rates such as in air ventilation and air cleanup systems at nuclear installations, adsorption on activated charcoal is the method most frequently used to trap radioiodine species. The capacity of activated charcoal to sorb organic iodides can be enhanced by impregnation with chemicals. The most widely used impregnants are $\mathrm{I}_{2}$, 
$\mathrm{KI}, \mathrm{KI}-\mathrm{I}_{2}$, KOH-I , triethylenediamine (TEDA), and hexamethylenetetramine (HMTA). However, charcoal has not generally been considered as a sorbent for off-gases from nuclear fuel reprocessing plants because: (1) it is deleteriously affected by nitrogen oxides (with the possible generation of explosive compounds ${ }^{44}$ ); (2) it desorbs iodine readily at high temperatures; (3) it has a low ignition temperature; (4) these cumulative effects render activated charcoal hazardous in treatment of off-gases and untrustworthy as a solid for long-term burial. Although activated charcoal is not normally considered a candidate for treatment of fuel reprocessing off-gases for the reasons listed, it is possible that banks of charcoal traps could be installed as a final emergency aircleaning system for the ventilation air in reprocessing plants.

Because activated charcoal cannot seriously be considered as a sorbent for nuclear fuel reprocessing plants, only a brief survey will be presented here of the voluminous literature associated with its utilization in cleanup of reactor operation off-gases. Emphasis is placed on references detailing early studies with activated charcoal for iodine removal, particularly those studies which examined the basic chemical mechanisms and attempted elucidation of the effects of the many parameters that are present in the iodine-charcoal binding process. Perhaps no process involving the treatment of radionuclide contaminated off-gases is as complicated as the use of activated charcoal to remove iodine species from very dilute concentrations in off-gases. Activated charcoal-bed filters have been used worldwide to treat nuclear power plant exhaust gases, and extensive experimental studies have been directed toward ascertaining the mechanistic intricacies of the charcoaliodine species interaction. However, the complexity of the chemical 
reaction and the effects of many operating parameters have defied tractable correlations; therefore, the utility companies and research installations generally rely on strict filtering schedules that have been established empirically after years of operating experience. These operating procedures must be adhered to and monitored very closely to ensure that one of the many process variables that can disrupt charcoal filter bed operation does not introduce a serious excursion into the iodine removal operation.

The complexity of attempting to define the function of activated charcoal filter beds for any prolonged period can be attributed to the multiparameter dependency of the iodine-charcoal sorption mechanism. In many studies, it has been shown that the sorption of $\mathrm{CH}_{3} \mathrm{I}$ (and to a much smaller degree, molecular iodine) onto activated charcoal is dependent on the following parameters: inlet concentration, superficial velocity, relative humidity, intense radiation field, temperature, charcoal mesh size, manufacturer, impregnant, bed depth, and run duration, and aging, weathering, and poisoning (these three may be intimately related). This list of parameters may not be totally inclusive of all possible operating condition effects. Few attempts have been made to collect and analyze the voluminous data obtained from experimental studies and actual plant operation for the removal of airborne iodine with activated charcoal. However, an in-depth and contemporary summary of the state of the art involved in use of charcoal to remove airborne iodine species from the gaseous effluents of nuclear facilities has recently been published. 45 


\subsubsection{Chemical mechanism}

Regardless of the impregnant in the charcoal, most investigators have agreed that molecular iodine is apparently adsorbed physically on active carbon sites. However, in a study of the capabilities of various impregnated charcoals to retain iodine at elevated temperatures $(4 \mathrm{hr}$ at $\left.180^{\circ} \mathrm{C}\right),{ }^{46}$ it was found that the iodine capacity was strongly dependent on the $\mathrm{pH}$ and alkali-metal content of the charcoals. The following expression was proposed to represent the interaction between $\mathrm{K}^{+}, \mathrm{I}^{-}$, and $\mathrm{pH}$ where conversion of elemental iodine to ionic iodine was the reaction that enhanced sorption:

$$
\mathrm{I} \text { a (atomic iodine) }+2 \mathrm{~K}^{+}+2 \mathrm{OH}^{-} \rightarrow 2 \mathrm{~K}^{+}+2 \mathrm{I}^{-}+\mathrm{H}_{2} \mathrm{O}+\frac{1}{2} \mathrm{O}_{2} .
$$

In a strongly basic environment, there could also be formation of other ionic forms of iodine such as iodate, hypoiodite, or periodate. It was concluded that because of its natural high content of $\mathrm{K}^{+}$and high $\mathrm{pH}$, coconut carbon was preferred as the natural base material for nuclear air cleaning applications; nevertheless, it was shown that a product equal to or better than $\mathrm{I}_{2}$-impregnated coconut carbons could be prepared from low-potassium carbon by treating it with $\mathrm{KOH}-\mathrm{I}_{2}$ mixtures.

The theory for the $\mathrm{CH}_{3} \mathrm{I}$-charcoal interaction is still being debated, but the mechanism that has been most widely accepted is that organic iodides are chemisorbed on activated carbon that has been impregnated with iodides by an isotopic exchange reaction. For example, for a $\mathrm{K}^{127} \mathrm{I}$ impregnate, 47

$$
\mathrm{CH}_{3}{ }^{131} \mathrm{I}(\mathrm{air})+\mathrm{K}^{127} \mathrm{I}(\text { charcoal }) \rightarrow \mathrm{CH}_{3}{ }^{127} \mathrm{I}(\mathrm{air})+\mathrm{K}^{131} \mathrm{I} \text { (charcoal) },
$$


where $\mathrm{CH}_{3}{ }^{131} \mathrm{I}$ is assumed to be a representative aliphatic iodide. Although only the iodine of the $\mathrm{CH}_{3} \mathrm{I}$ compound is involved in the isotopic exchange mechanism, the removal efficiency of $\mathrm{CH}_{3}{ }^{131} \mathrm{I}$ is assumed to be the same as that of ${ }^{131} \mathrm{I}^{-}$.

Heterocyclic amines appear to be excellent ligand molecules for sorption of organic iodides because the amine is more reactive with organic iodide than with water, and the double amine groups provide a strong attachment to both the charcoal and the organic iodide. The reaction is generally shown as:

$$
\mathrm{R}_{3} \mathrm{~N}+\mathrm{CH}_{3}{ }^{131} \mathrm{I} \rightarrow \mathrm{R}_{3} \mathrm{~N}^{+} \mathrm{CH}_{3}{ }^{131} \mathrm{I}^{-} \text {, }
$$

so that the quaternary amine is then adsorbed strongly to the charcoal.

Recently, a somewhat different mechanism than that shown in Eq. (20) was proposed, although the end product is the same. It was hypothesized that iodine is trapped by charcoal sorbents as a catalytic process where the carbon acts as a catalyst support, but it would not be completely inert in the reaction. The proposed mechanism was:

$$
\begin{aligned}
& \mathrm{CH}_{3}{ }^{131} \mathrm{I}(\mathrm{g})+\mathrm{K}^{+} \mathrm{OI}^{-}(\mathrm{c}) \rightarrow \mathrm{CH}_{3} \mathrm{OI}(\mathrm{g})+\mathrm{K}^{131} \mathrm{I}(\mathrm{c}), \\
& \mathrm{CH}_{3} \mathrm{OI}(\mathrm{g})+\mathrm{K}^{+}(\mathrm{OH})(\mathrm{c}) \rightarrow \mathrm{CH}_{3} \mathrm{OH}(\mathrm{g})+\mathrm{K}^{+} \mathrm{OI}^{-}(\mathrm{c}),
\end{aligned}
$$

where $g$ is gas and $c$ is charcoal. The mechanism provides an explanation for the experimental observation that removal efficiency increases with $\mathrm{pH}$. The chain reaction, involving regeneration of the active $\mathrm{OI}^{-}$species, could be terminated by acidification arising from organic poisons collected from the air stream, by reaction products $\left(\mathrm{CH}_{3} \mathrm{OH}\right)$, or by poisons inherent in the charcoal itself. 
3.1.3 Standard operating conditions for activated charcoal beds utilized in iodine species removal from nuclear power plant off-gases

In the event of a major accident at a nuclear reactor, the concentration of iodine in the ventilation air could be as much as $5000 \mathrm{mg} / \mathrm{m}^{3}(\sim 500 \mathrm{ppm}$ $I_{2}$, depending on reactor size, degree of fuel burnup at the time of the accident, and the nature of the accident. One of the main design considerations in iodine containment at a nuclear reactor is to ensure the capability of charcoal bed filters to remove iodine from the off-gas at routine concentrations of $\leq 10^{-3} \mathrm{\mu g} \mathrm{I}_{2} / \mathrm{m}^{3}$; in addition, the filters must retain an acceptable removal efficiency for the treatment of concentrations as large as $10^{3} \mathrm{mg} \mathrm{I}_{2} / \mathrm{m}^{3}$ for short bursts at times of accidental release. Thus in the many experiments that have involved charcoal filtration of iodine-bearing gas streams, feed concentrations have been used that vary from $10^{-6} \mathrm{\mu g} / \mathrm{m}^{3}$ to $3000 \mu \mathrm{g} / \mathrm{m}^{3}$ of $\mathrm{CH}_{3}{ }^{131} \mathrm{I}$. The variation in DF with inlet concentration has been one of the major functional dependencies of the iodine-charcoal sorption process, along with the variation of DF with superficial velocity, relative humidity, aging, and weathering. However, it has been stressed ${ }^{49}$ that much of the concern about the ability of charcoal to interact with iodine concentrations below $10^{-3} \mathrm{\mu g} / \mathrm{m}^{3}$ may have been unnecessary, because the typical average total (normal and radioactive) iodine content in the atmosphere is in the $10^{-2}$ to $10^{-3} \mu \mathrm{g} / \mathrm{m}^{3}$ range. Thus the lower concentrations can be expected only for such dilute radioactive species as ${ }^{131} \mathrm{I}_{2}, \mathrm{CH}_{3}{ }^{131} \mathrm{I}$, or $\mathrm{HO}^{131} \mathrm{I}$.

In the United States, ${ }^{50}$ representative samples matching the history of those in the filter trays are tested periodically in a laboratory with 
$\mathrm{CH}_{3}{ }^{131} \mathrm{I}$ and ${ }^{131} \mathrm{I}_{2}$, whereas leak tests of the actual functioning tray configuration are conducted with freon. 51,52 Minimum efficiencies for $\mathrm{I}_{2}$ and $\mathrm{CH}_{3} \mathrm{I}$ at low $\left(21^{\circ} \mathrm{C}\right)$ and high $\left(80^{\circ} \mathrm{C}\right)$ temperatures and 10 ( $70 \%$ and high $(>95 \%)$ relative humidity are specified in ANSI N509 and RDT/M/16-1. 52,53 Any good grade of activated carbon, with or without impregnant, will deliver a $D F$ of 100 for $I_{2}$ with any combination of temperature and humidity that would be encountered in a nuclear air-cleaning system. However, impregnated charcoals are required to trap highly penetrating organic iodides (or HOI). The efficiency of these charcoals is dependent on flow conditions, so that performance of the activated charcoals for organic iodides in the United States must be qualified under a range of operating conditions specified in RDT/M/16-1. In Europe, the testing of charcoal filters at nuclear facilities is achieved in situ for the installed system by periodic injection of $\mathrm{CH}_{3} \mathrm{I}$ and/or $\mathrm{I}_{2} \cdot 54$

\subsubsection{Experimental results and present applications of activated charcoal to filter iodine species from nuclear facility off-gases}

No effort was made to review every study in which charcoal, either activated only or also with impregnants, has been used to remove $\mathrm{I}_{2}$ and $\mathrm{CH}_{3} \mathrm{I}$ from gas streams. However, certain key studies, inclusive of the time from process introduction to present status of the art, are shown in Table 3, along with the parameters of iodine-charcoal sorption operation specifically investigated. $44,46-48,55-80$

Among the major developments was the introduction ${ }^{59}$ of impregnated charcoals for iodine species removal. At about the same time, Collins et al. 60 found that KI-impregnated carbons demonstrated better removal efficiency for $\mathrm{CH}_{3}{ }^{131} \mathrm{I}$ than did untreated carbons. After the publication of these 
Table 3. Summary of literature survey of the main operating parameters and their effect on the decontamination factor $(D F)$ for $\mathrm{CH}_{3} \mathrm{I}$ and $\mathrm{I}_{2}$ removal from gases with activated charcoal

\begin{tabular}{|c|c|c|c|c|}
\hline Parameter & $\begin{array}{l}\text { General variation } \\
\text { in DF for } \mathrm{CH}_{3} \mathrm{I}\end{array}$ & $\begin{array}{c}\text { Relevant studies } \\
\text { (ref.) }\end{array}$ & $\begin{array}{l}\text { General variation } \\
\text { in DF for } I_{2}\end{array}$ & $\begin{array}{l}\text { Relevant studies } \\
\text { (ref.) }\end{array}$ \\
\hline Inlet concentration & Inversely & 55,56 & None & $56-58$ \\
\hline Superficial velocity & Inversely & $56,59-62$ & None & $56-58,61$ \\
\hline Charcoal mesh size & Inversely & $56,60,63$ & None & 56,63 \\
\hline Manufacturer & Strong effect & $56,60,61,64,65$ & None & $46,56,64,66-68$ \\
\hline Impregnant & $\begin{array}{l}\text { Directly; generally } \\
\text { improved performance }\end{array}$ & $47,48,56,59-65,69$ & Better with high alkali & $46,56,64,66-68$ \\
\hline Bed depth & Directly & $56,59,62,64,65$ & Directly & 64 \\
\hline $\begin{array}{l}\text { Aging, weathering, } \\
\text { poisoning }\end{array}$ & Inversely & $56,60,61,63-74$ & Inversely & $57,58,61,64,66-69$ \\
\hline Run time & Inversely & a & $\begin{array}{l}\text { Inversely for extended } \\
\text { times }\end{array}$ & $46,57,58,66-68$ \\
\hline Temperature & Inversely & $60,61,63,64,75$ & $\begin{array}{l}\text { Inversely at high } \\
\text { temperatures }\end{array}$ & $46,57,58,61,66-68$ \\
\hline Ignition & Destructive & $44,48,75-80$ & Destructive & Same as for $\mathrm{CH}_{3} \mathrm{I}$ \\
\hline Relative humidity & Inversely & $55,56,59-61,63,64,69$ & None under $100 \%$ & $55-58,61,69$ \\
\hline $\begin{array}{l}\text { Highly intense } \\
\text { radiation field }\end{array}$ & Inversely & $61,63,66-69$ & Inversely & $61,63,69$ \\
\hline
\end{tabular}

a Run time is a parameter whose effects are very closely related to those of aging, weathering and poisoning, so that generally DFs deteriorate with extended run time, aging; etc. 
two articles describing the initial discovery of the advantages of $\mathrm{I}_{2}{ }^{-}$ and $\mathrm{K}^{+}$-impregnated charcoals, there was a proliferation in the number of studies of impregnated charcoals. ${ }^{81-83}$ The Collins paper ${ }^{60}$ was essentially a classic study of the efficiency of KI- and TEDA-impregnated charcoals to remove $\mathrm{CH}_{3} \mathrm{I}$. The effect on the DF and loading capacity of $\mathrm{CH}_{3} \mathrm{I}$ was studied as a function of $\mathrm{CO}_{2}$, temperature to superheated steam, $\mathrm{H}_{2} \mathrm{O}$ condensation effect, relative humidity, charcoal mesh size, manufacturer, aging, organic weathering, and run time. An extensive parametric study concerning the DFs for $\mathrm{I}_{2}$ and $\mathrm{CH}_{3} \mathrm{I}$ obtained on various charcoals for very low feed concentrations was published later. 56

Only a few attempts have been made to develop empirical correlations to predict the $\mathrm{DF}$ for $\mathrm{CH}_{3} \mathrm{I}$ removal from off-gases as a function of some or all of the parameters listed in Table $3,56,84$ but no attempt has been inclusively successful.

A few studies have indicated that flooding of charcoal beds with water effectively destroys their capability to trap iodine in any form and would also result in the release of any radioiodine that has been trapped. 60,85

Some iodine loss will occur at desorption temperatures in excess of the adsorption temperature, particularly from impregnated charcoals. The higher temperatures may also desorb some of the impregnant and further reduce the capacity for organic iodides.

Two major concerns in the application of activated charcoal to treat off-gases containing radioiodine are: (1) the possibility of a slow release of large concentrations of iodine which have been sorbed onto charcoal during accidental conditions or after long periods of routine 
treatment of off-gases from reactor facilities, $66-69,75$ and

(2) the possibility of ignition of the charcoal due to the decay heat generated by collected fission products (particularly ${ }^{131} \mathrm{I}$ ). Numerous studies have been conducted to define the major parameters that affect the slow release of iodine from preloaded activated charcoal. It has been determined ${ }^{69}$ that the release was dependent on at least four environmental parameters: (1) the service history, (2) organic contaminants in the air, (3) the relative humidity, and (4) ionizing radiation. For coconut-based charcoals in $28 \mathrm{~cm}^{3}$ beds, with iodine loads ranging from 50 to $570 \mathrm{Ci}$ (relative humidity was $47 \%$ at the bed-inlet temperature of $70^{\circ} \mathrm{C}$ ), it was found ${ }^{61}$ that radioactive iodine was released from test beds for all charcoals tested. The chemical form of the released iodine, which was very highly penetrating with respect to several different kinds of commercial impregnated charcoal, was not determined (it could possibly have been HOI or some similar unusual iodine species). The formation of this highly penetrating iodine species was apparently promoted by moisture and radiation.

For removing airborne iodine with impregnated activated charcoal, the ignition temperature of charcoal is a function of adsorbed fission product concentration, internal surface area, ash content, impurities, mesh size, ignition temperatures of impregnants, bed depth, and gas flow through the bed. $47,61,76-80,85$ The ignition point may be further affected by adsorbed compounds (such as solvents and hydrocarbons). The lowest ignition point for KI-impregnated coconut-based charcoals has been about $300^{\circ} \mathrm{C} .^{78}$ Ignition of TEDA-impregnated charcoals may occur at temperatures as $10 \mathrm{w}$ as $180^{\circ} \mathrm{C}$ depending on the degree of impregnation, 
the gas. flow rate, and bed depth. The only method of bed cooling normally utilized for charcoal filters is forced-air circulation. It is generally suggested that ignition caused by radioiodine decay heat can be avoided by maintaining air flow in excess of $5 \mathrm{fpm}$. According to Lorenz et al., 61 when the velocity of moist air was decreased from $28.5 \mathrm{fpm}\left(25^{\circ} \mathrm{C}\right)$ to $0.71 \mathrm{fpm}$, the temperature of the charcoal bed preloaded with radioiodine reached the ignition point in three cases. Charcoal exposed for 4 years ignited at $283^{\circ} \mathrm{C}$, as compared with ignition at $368^{\circ} \mathrm{C}$ for unused charcoal from the same batch. For $28 \mathrm{~cm}^{3}$ of charcoal, the ignition temperatures and radioiodine loading were: (1) $283^{\circ} \mathrm{C}$ at $260 \mathrm{Ci}$ of ${ }^{130} \mathrm{I}$; (2) $307^{\circ} \mathrm{C}$ at $>291 \mathrm{Ci}$ of ${ }^{130} \mathrm{I}$; and (3) $310^{\circ} \mathrm{C}$ at $240 \mathrm{Ci}$ of ${ }^{130} \mathrm{I}$.

\section{1 .5 Process capacity}

The loading capacity of activated charcoal for iodine species is intimately related to many operating parameters, but apparently the most important variables are type of iodine species, relative humidity, temperature, run time (and effects of weathering and poisoning), bed depth, and superficial velocity. In general, to maintain efficient iodine removal $\geq 99 \%\left(\mathrm{DF}>10^{2}\right)$ for feed gases containing highly penetrating iodine species (HOI or organic iodides), it is necessary to restrict the run time and thus reduce loading capacity to maintain DF, or to elongate the bed to both maintain the DF and retain loading capacity.

In early studies utilizing activated charcoal for iodine species removal from off-gases, loadings of 0.005 to $0.08-\mathrm{mg} \mathrm{CH}_{3} \mathrm{I} / \mathrm{g}$ impregnated charcoal were obtained ${ }^{59}$ for a wide range of run conditions, which included as much as $70 \%$ relative humidity, while retaining a $\mathrm{DF}>10^{2}$ for 
up to $28 \mathrm{hr}$. To maintain DFs of $10^{3}$ for $\mathrm{CH}_{3} \mathrm{I}$ removal for run times up to $27 \mathrm{hr}$, Collins ${ }^{60}$ limited his loading to $0.1-\mathrm{mg} \mathrm{CH}_{3} \mathrm{I} / \mathrm{g}$ of $\mathrm{KI}$-impregnated charcoal and to $1-\mathrm{mg} \cdot \mathrm{CH}_{3} \mathrm{I} / \mathrm{g}$ of TEDA-impregnated charcoal. For feed concentrations of $10-\mathrm{mg} \mathrm{CH}_{3} \mathrm{I} / \mathrm{m}^{3}$, Ludwick ${ }^{64}$ achieved loadings of 1 to 2-mg $\mathrm{CH}_{3} \mathrm{I} / \mathrm{g}$ of charcoal for flow conditions as stringent as $100^{\circ} \mathrm{C}$ and $100 \%$ relative humidity; however, the DFs were reduced to about 10 for $2.54-\mathrm{cm}-10$ ng beds and to 2100 for $5.08-\mathrm{cm}-1$ long beds. The DFs for elemental iodine were always higher than those for $\mathrm{CH}_{3} \mathrm{I}$ at similar operating conditions. In studies of the utilization of silver-exchanged zeolites for iodine species removal, Pence et al. ${ }^{86}$ investigated comparative $\mathrm{CH}_{3} \mathrm{I}$ loading capacities of $\mathrm{AgX}$ and activated charcoal. They were able to obtain $\mathrm{CH}_{3} \mathrm{I}$ loading on activated charcoal of as much as 11-mg $\mathrm{CH}_{3} \mathrm{I} / \mathrm{g}$ of charcoal for a $200-\mathrm{mg} \mathrm{CH}_{3} \mathrm{I} / \mathrm{m}^{3}$ feed, but the penalty was a reduction in $\mathrm{DF}$ to only 100 for $\mathrm{CH}_{3} \mathrm{I}$ in dry air at $25^{\circ} \mathrm{C}$. Note that the DFs achieved for both $\mathrm{AgX}$ and charcoal are drastically reduced at ambient conditions with increasing relative humidities.

Recently, wilhelm ${ }^{45}$ stated that to maintain removal efficiencies consistent with existing environmental standards for the iodine content of nuclear power plant off-gases, loadings should not exceed $0.1 \mathrm{mg}$ of $\mathrm{CH}_{3} \mathrm{I}$ and $\mathrm{I} \mathrm{mg}$ of molecular $\mathrm{I}_{2}$ per gram of charcoal for KI-impregnated charcoals; however, for TEDA-impregnated charcoals, loading should not exceed $1 \mathrm{mg}$ of $\mathrm{CH}_{3} \mathrm{I} / \mathrm{g}$ of charcoal. 


\subsection{Removal of Iodine Species from off-Gases by Utilizing Meta1-Exchanged Zeolites}

\subsubsection{Background}

Silver and other metal-exchanged zeolites were among the first alternative sorbents proposed to replace charcoal for removal of iodine species from nuclear facility off-gases. These sorbents are prepared by a replacement of sodium ions in the zeolite structure by the other cations. The most extensive studies have been conducted and the best iodine removal efficiencies have been obtained with silver-exchanged zeolites $(\mathrm{AgX})$.. Among the other cations that have been studied are $\mathrm{Cd}, \mathrm{Cu}, \mathrm{Pb}, \mathrm{K}, \mathrm{Hg}, \mathrm{Zn}, \mathrm{Mn}, \mathrm{Co}$, and $\mathrm{Ni}$. Promising cation zeolites were those derived from $\mathrm{Pb}, \mathrm{K}$, and $\mathrm{Cd}$, but none of these were as efficient as Ag. The silver zeolites offered advantages such as stability, nonflammability, low-explosion hazard, and a stable disposal form.

\subsubsection{Chemica1 mechanism}

The chemical mechanism involved in the sorption of iodine species on metal-exchanged zeolites has not been rigorously determined. However, the kinetics of the silver zeolite--iodine interaction may be similar to those proposed by Wilhelm et al. ${ }^{45}$ for silver-substituted amorphous alumina-silicates where silver iodides are postulated as the end product.

\subsubsection{Experimental results and engineering data useful for process design}

Maeck et al. ${ }^{87}$ screened a variety of organic and inorganic sorbents used to remove molecular iodine and methyl iodide from water-saturated air $\left(\right.$ at $25^{\circ} \mathrm{C}$ ) and steam-air mixtures. The most efficient adsorbent was silver-exchanged 13X-molecular sieve (zeolite). The AgX ( $99 \%$ exchanged) 
could efficiently adsorb iodine up to $500^{\circ} \mathrm{C}$ and could retain it to $1000^{\circ} \mathrm{C}$. Based on iodine retention at high temperatures, flammability, and performance in steam, silver-exchanged zeolites were superior to KI-impregnated charcoal.

Subsequently, more extensive experiments ${ }^{86}$ were conducted to determine the $\mathrm{CH}_{3} \mathrm{I}$ removal efficiency of $\mathrm{AgX}$ as affected by the parameters of relative humidity, temperature, superficial velocity, bed depth, loading capacity, feed concentration, and inorganic and organic feed contaminants. The DF for $\mathrm{CH}_{3} \mathrm{I}$ varied inversely with relative humidity for a given temperature, but the variation was less at higher temperatures. When the relative humidity was increased from 80 to $100 \%$, the trapping efficiency decreased from 99.8 to $92.5 \%$ in one series of tests with the following parameters: feed concentration, $10 \mu \mathrm{g}$ of $\mathrm{CH}_{3} \mathrm{I} / \mathrm{m}^{3}$; superficial velocity, $\sim 35.0 \mathrm{~m} / \mathrm{min}$; and temperature, $60^{\circ} \mathrm{C}$. The $\mathrm{DF}$ for $\mathrm{CH}_{3} \mathrm{I}$ also varied inversely with superficial velocity. When $\mathrm{CH}_{3} \mathrm{I}$ was removed from dry air at $25^{\circ} \mathrm{C}$, the loading capacity of $\mathrm{AgX}$ increased as the $\mathrm{CH}_{3} \mathrm{I}$ concentration decreased. The loading capacity increased from 37 to 84-mg $\mathrm{CH}_{3} \mathrm{I} / \mathrm{g}$ of $\mathrm{AgX}$ when the $\mathrm{CH}_{3} \mathrm{I}$ concentration was decreased from 5000 to $230 \mathrm{mg} / \mathrm{m}^{3}$ ( 850 to $39 \mathrm{ppm}$ ), but the $\mathrm{DF}$ was maintained at $10^{4}$. The loading capacity of Barnebey-Cheney-727 impregnated charcoal was comparable to that of $\mathrm{AgX}$ at high $\mathrm{CH}_{3} \mathrm{I}$-feed concentrations, but it was significantly lower for $\mathrm{CH}_{3}$ I concentrations $<0.5 \mathrm{~g} / \mathrm{m}^{3}$ (85 ppm). Methyl iodide was much more susceptible to leaching with water when sorbed to charcoal than when sorbed to $\mathrm{AgX}$. When molecular iodine was removed from air at $25^{\circ} \mathrm{C}$ and $92 \mathrm{ft} / \mathrm{min}$, $\mathrm{AgX}$ was found to be reasonably resistant to poisoning by the contaminant gases $\mathrm{NO}_{2}, \mathrm{CO}_{2}, \mathrm{O}_{2}, \mathrm{SO}_{2}, \mathrm{H}_{2} \mathrm{~S}$, propane, 
and hexane. Details of the operating conditions and their effects on the AgX-iodine interaction for some of the most significant studies of AgX are summarized in Table $4.86,88-90$

Maeck and Pence 91 a1so determined that the $\mathrm{CH}_{3} \mathrm{I}$ loading capacity and the $\mathrm{CH}_{3} \mathrm{I}$ achievable on $\mathrm{AgX}$ could be increased significantly, expecially in the presence of $\mathrm{H}_{2} \mathrm{O}$, by heating the $\mathrm{AgX}$ beds (see data for ref. 86 in Table 4). This effect was attributed to a reduction in relative humidity and an increase in the reaction rate between $\mathrm{AgX}$ and $\mathrm{CH}_{3} \mathrm{I}$. The adsorption capacity for molecular $\mathrm{I}_{2}$ of lead-exchanged zeolite was strongly dependent on the relative humidity. The alternate use of tandem beds of $\mathrm{AgX}$ and $\mathrm{PbX}$ for iodine removal was suggested to minimize the cost of once-through use of $\mathrm{AgX}$ beds. Increased $\mathrm{I}_{2}$ sorption on $\mathrm{PbX}$ could also be obtained by heating the $\mathrm{PbX}$ bed. Silver zeolite had a high affinity for hydrogen at temperatures $>100^{\circ} \mathrm{C}$. The capacity of $\mathrm{AgX}$ for $\mathrm{CH}_{3} \mathrm{I}$ was at least 20 times that of charcoal (100 vs $5-\mathrm{mg} \mathrm{CH}_{3} \mathrm{I} / \mathrm{g}$ sorbent). However, $\mathrm{AgX}$ was at least 20 times as expensive as an equal weight of charcoal. Because it was less flammable and less affected by high temperatures than charcoal (both, however, are deleteriously affected by high concentrations of $\mathrm{NO}_{\mathrm{x}}$ gases at $100 \%$ relative humidity), $\mathrm{AgX}$ was proposed for use in treating off-gases from nuclear fuel reprocessing plants.

In further tests, Pence et al. ${ }^{89}$ studied the effect on $\mathrm{CH}_{3} \mathrm{I}$ removal with $\mathrm{AgX}$ beds of such variables as high bed temperature, high relative humidity, steam atmosphere, particle size, contaminant gases, and feed $\mathrm{CH}_{3} \mathrm{I}$ concentration. The adsorption efficiency of $\mathrm{CH}_{3} \mathrm{I}$ from air at $90^{\circ} \mathrm{C}, 90 \%$ relative humidity (feed level of $0.1 \mu \mathrm{g} \mathrm{CH} \mathrm{I}^{\mathrm{I} / \mathrm{m}^{3}}$ or $\left.1.7 \times 10^{-5} \mathrm{ppm}\right)$, and $14 \mathrm{~m} / \mathrm{min}$ was not affected by $\mathrm{O}_{2}, \mathrm{CO}_{2}, \mathrm{NO}_{2}, \mathrm{H}_{2}$, 
Table 4. Effects of variations in feed concentration, temperature, and relative humidity on the capability of silver zeolites to remove iodine species from off-gases

\begin{tabular}{|c|c|c|c|c|c|c|c|c|c|c|c|}
\hline $\begin{array}{l}\text { Ref. } \\
\text { No. }\end{array}$ & Sorbent & $\begin{array}{c}\mathrm{CH}_{3} \mathrm{I} \text { feed } \\
\text { concentration } \\
\left(\text { per } \mathrm{m}^{3}\right)\end{array}$ & $\begin{array}{c}\mathrm{I}_{2} \text { feed } \\
\text { concentration } \\
\left(\text { per } \mathrm{m}^{3}\right)\end{array}$ & $\begin{array}{l}\text { Gas } \\
\text { superficial } \\
\text { velocity } \\
(\mathrm{m} / \mathrm{min})\end{array}$ & $\begin{array}{c}\text { Ambient } \mathrm{b}^{\mathrm{b}} \\
\mathrm{H}_{2} \mathrm{O} \\
\text { concentration } \\
(\%)\end{array}$ & $\begin{array}{l}\text { Relative } \\
\text { humidity } \\
(\%)\end{array}$ & $\begin{array}{c}\text { Feed gas } \\
\text { temp } \\
\left({ }^{\circ} \mathrm{C}\right)\end{array}$ & Loading capacity & DF & $\begin{array}{l}\text { Run } \\
\text { time } \\
\text { (hr) }\end{array}$ & $\begin{array}{l}\text { Bed } \\
\text { depth } \\
(\mathrm{cm})\end{array}$ \\
\hline \multirow[t]{7}{*}{88} & $90 \% \mathrm{AgX}^{\mathrm{C}}$ & $.222 \mathrm{mg}$ & & 12 & 2.3 & 90 & 27 & $12 \mathrm{mg} \mathrm{CH}{ }_{3} \mathrm{I} / \mathrm{cm}^{3 \mathrm{~d}}$ & 27 & 4 & 5.08 \\
\hline & $90 \% A g x^{c}$ & $200 \mathrm{mg}$ & & 12 & 0 & 0 & 26 & $11.2 \mathrm{mg} \mathrm{CH}{ }_{3} \mathrm{I} / \mathrm{cm}^{3}$ & $1 \times 10^{4}$ & 4 & 5.08 \\
\hline & $98 \% \mathrm{AgX}^{\mathrm{C}}$ & $4.4 \mathrm{mg}$ & & 19 & 2.3 & 0.14 & 200 & $9.1 \mathrm{mg} \mathrm{CH}{ }_{3} \mathrm{I} / \mathrm{cm}^{3}$ & $2 \times 10^{4}$ & 100 & 5.08 \\
\hline & $98 \% \mathrm{AgX}$ & $129 \mathrm{mg}$ & & 19 & 2.3 & 0.14 & 200 & $10.6 \mathrm{mg} \mathrm{CH}{ }_{3} \mathrm{I} / \mathrm{cm}^{3}$ & $3 \times 10^{4}$ & 4 & 5.08 \\
\hline & $90 \% \operatorname{sgX^{c}}$ & $816 \mathrm{mg}$ & & 19 & 2.3 & 0.14 & 200 & $74 \mathrm{mg} \mathrm{CH}_{3} \mathrm{I} / \mathrm{cm}^{3}$ & $1 \times 10^{4}$ & 4 & 5.08 \\
\hline & $90 \% \mathrm{AgX}^{\mathrm{C}}$ & & ح12 mg & 15 & 2.3 & 2.3 & 100 & $6.6 \mathrm{mg} \mathrm{I} / 2 / \mathrm{cm}^{3}$ & $1 \times 10^{5}$ & 31 & 5.08 \\
\hline & $90 \% A g X^{c}$ & & $2,8.0 \mathrm{mg}$ & 19 & 2.3 & 0.14 & 200 & $5.7 \mathrm{mg} \mathrm{I}_{2} / \mathrm{cm}^{3}$ & $3 \times 10^{5}$ & 31 & 5.08 \\
\hline \multirow[t]{7}{*}{86} & $99 \% \mathrm{AgX}^{\mathrm{e}}$ & 0.1 to $210 \mathrm{lg}$ & & 28 & 2.8 & 90 & 25 & $N D^{f}$ & 16.6 & 1.0 & 5.08 \\
\hline & $99 \% \mathrm{AgX}^{\mathrm{e}}$ & 0.1 to $210 \mathrm{ug}$ & & 28 & 3.0 & 95 & 25 & ND & 12.5 & 1.0 & 5.08 \\
\hline & $99 \% \mathrm{AgX}^{\mathrm{e}}$ & 0.1 to $210 \mathrm{ug}$ & & 28 & 3.2 & 100 & 25 & ND & 10 & 1.0 & 5.08 \\
\hline & $99 \% \mathrm{AgX}^{\mathrm{e}}$ & 0.1 to $210 \mathrm{ug}$ & & 17 & 17.7 & 90 & 60 & $\mathrm{ND}$ & 142 & 1.0 & 5.08 \\
\hline & $99 \% \mathrm{AgX}^{\mathrm{e}}$ & 0.1 to $\sim 10$ & & 19 & 62 & 89 & 90 & ND & 330 & 1.0 & 5.08 \\
\hline & $99 \% \mathrm{Agx}^{\mathrm{e}}$ & . & . 5 to $100 \times 10^{3} \mathrm{ug}$ & 28 & 22.0 & 100 & 22 & ND & $>10^{4}$ & ND & 5.08 \\
\hline & $99 \% \mathrm{AgX}^{\mathrm{e}}$ & $230 \mathrm{mg}$ & & 14 & 0 & 0 & 25 & $84 \mathrm{mg} \mathrm{CH}_{3} \mathrm{I} / \mathrm{g}$ & $>10^{4}$ & 26 & 5.08 \\
\hline \multirow[t]{4}{*}{89} & $99 \% \mathrm{AgX}^{\mathrm{e}}$ & 0.1 to $10 \mathrm{Hg}$ & & 15 & & 90 & 90 & $\mathrm{ND}$ & $1.2 \times 10^{5}$ & $1-6$ & 10 \\
\hline & $99 \% \mathrm{AgX}^{\mathrm{e}}$ & $10^{-5}$ to $10^{-4}: g$ & & 15 & & 90 & 90 & ND & $4 \times 10^{3}$ & $1-6$ & 10 \\
\hline & $99 \% \mathrm{AgX}^{\mathrm{e}}$ & $10^{-5}$ to $10^{-4}$ : $\mathrm{g}$ & & 30 & & 90 & 90 & ND & $4 \times 10^{3}$ & $1-6$ & 10 \\
\hline & $99 \% A g X^{B}$ & 0.1 to $10 \mathrm{ug}$ & & 15 & & 90 & 90 & $\mathrm{ND}$ & $2 \times 10^{3}$ & $1-6$ & 10 \\
\hline \multirow[t]{3}{*}{90} & $\mathrm{AgX}$ & & $500 \mathrm{mg}$ & 60 & $5^{h}$ & 5 & 100 & $42 \mathrm{mg} \mathrm{I} / \mathrm{g}^{\mathrm{d}}$ & $2 \times 10^{2^{i}}$ & $5-16$ & 10 \\
\hline & $\mathrm{AgX}$ & & $500 \mathrm{mg}$ & 60 & $5^{h}$ & 0.32 & 200 & $55 \mathrm{mg} \mathrm{I} / \mathrm{g}$ & $2 \times 10^{2}$ & $5-16$ & 10 \\
\hline & $\mathrm{AgX}$ & & $500 \mathrm{mg}$ & 60 & 0 & 0 & 100 & $139 \mathrm{mg} \mathrm{I}_{2} / \mathrm{g}$ & $2 \times 10^{2}$ & $5-16$ & 10 \\
\hline
\end{tabular}

$a_{\text {For }} 21^{\circ} \mathrm{C}$ and $1 \mathrm{~atm}, 1 \mathrm{ug} \mathrm{CH} \mathrm{CH}_{3} \mathrm{~m}^{3}=1.7 \times 10^{-4} \mathrm{ppm}, 1$ ug $\mathrm{I}_{2} / \mathrm{m}^{3}=9.5 \times 10^{-5} \mathrm{ppm}$.

$\mathrm{f}_{\text {Not determined. }}$

${ }^{b}$ Assuming water vapor as ideal gas.

$\mathrm{g} 10-20$ mesh beads.

${ }^{c} 1 / 16-i n$. pellets.

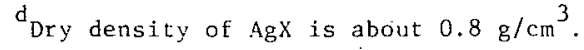

hor these cases, feed gas contained $2 \% \mathrm{NO}_{2}$

$i_{\text {Loading until breakthrough. }}$

$e_{12-14}$ mesh beads. 
propane, hexone, or kerosene (remaining at $99.9 \%$ ), but it was seriously decreased by $\mathrm{H}_{2} \mathrm{~S}$ and $\mathrm{SO}_{2}$ (reduced to 30 to $40 \%$ ). Deleterious effects were indicated for high concentrations of $\mathrm{NO}_{2}$ and $\mathrm{C}_{3} \mathrm{H}_{8}$. Exposure of $\mathrm{AgX}$ to high-temperature saturated steam $\left(139^{\circ} \mathrm{C}\right)$ for $5 \mathrm{hr}$ resulted in a severe loss in $\mathrm{CH}_{3} \mathrm{I}$ removal efficiency; however, no known solid sorbent would be able to withstand this treatment. The granular AgX sorbents produced much better $\mathrm{CH}_{3} \mathrm{I}$ removal than did the beaded AgX sorbents. The DFs for $\mathrm{CH}_{3} \mathrm{I}$ obtained with 12- to 14-mesh granulated AgX were as much as 20 times greater than the DFs obtained with 14- to 18-mesh beaded AgX sorbent.

Although the normal atmospheric concentration of iodine is $10^{-2}$ to $10^{-3} \mathrm{\mu g} / \mathrm{m}^{3}\left(9.5 \times 10^{-6}\right.$ to $\left.9.5 \times 10^{-7} \mathrm{ppm}\right),{ }^{49}$ some of the hazardous organic radionuclides (and $\mathrm{HOI}$ ) may be included in off-gases at concentrations in the $10^{-10}$ to $10^{-2} \mathrm{\mu g} / \mathrm{m}^{3}$ range; it is therefore important to know how these low concentrations affect the function of the AgX beds. For a feed gas at $90^{\circ} \mathrm{C}$ and $90 \%$ relative humidity, Pence et al. ${ }^{89}$ studied the effects of bed depth $(2.5$ to $10 \mathrm{~cm}), \mathrm{CH}_{3} \mathrm{I}$ concentration $\left(10^{-5}\right.$ to $\left.10 \mu \mathrm{g} / \mathrm{m}^{3}\right)$, and face velocity $(25$ and $50 \mathrm{~cm} / \mathrm{sec}$ ) on the DFs obtained with beads of $\mathrm{AgX}, \mathrm{KI}-\mathrm{I}_{2}-$ and TEDA-impregnated charcoals, and granular AgX. The relationship between $\mathrm{CH}_{3} \mathrm{I}$ removal and run conditions was extremely complicated, with the $\mathrm{CH}_{3} \mathrm{I}-\mathrm{AgX}$ interaction being affected by variables such as adsorbate concentration, relative humidity, presence of contaminant gases, adsorbent efficiency, superficial velocity, particle size, temperature, and chemical species of iodine. For sufficiently long beds $(10 \mathrm{~cm})$, there appeared to be no sizeable dependency of $\mathrm{DF}$ for $\mathrm{CH}_{3} \mathrm{I}$ on the airborne 
$\mathrm{CH}_{3} \mathrm{I}$ concentration in the range $10^{-5}$ to $10 \mu \mathrm{g} / \mathrm{m}^{3}$. This observation has been thoroughly discussed in other works. ${ }^{45,55}$

In a review of methods used to remove airborne radioiodine by primary and secondary processes (primary for raw off-gas, secondary as a polishing step), and based on the limited operational experience at that time, it was concluded ${ }^{92}$ that:

1. Due primarily to consideration of chemical cost, an acidscrubbing process such as the use of $\mathrm{Hg}\left(\mathrm{NO}_{3}\right)_{2}-\mathrm{HNO}_{3}$ might be more widely used than solid sorbents for iodine species collection. However, insufficient costing and pilot plant operation data were available to allow a final selection of a process to remove iodine from fuel reprocessing off-gases.

2. In a secondary iodine removal system, the solid sorbents appeared to be more desirable because of ability to handle relatively larger flow rates in a simpler operation than that provided by acid-scrubbing methods. Staples et al. ${ }^{90}$ conducted tests to determine: (1) iodine loading capacities of $\mathrm{AgX}, \mathrm{CdX}, \mathrm{NaX}, \mathrm{PbX}, \mathrm{ZnX}$, and $\mathrm{CuX}$; and (2) a method of regenerating $\mathrm{AgX}$, after loading it with $I_{2}$, with hydrogen at elevated temperatures. For air containing $90 \mathrm{mg} \mathrm{I} / \mathrm{m}^{3}$ and $1.5 \%$ water vapor at $100^{\circ} \mathrm{C}$ and $200^{\circ} \mathrm{C}$, the only two metal-exchanged zeolites for which $\mathrm{I}_{2}$-removal efficiencies remained greater than $99 \%$ were cadmium and sodium. The amounts of $\mathrm{I}_{2}$ chemisorbed at $150^{\circ} \mathrm{C}$ were $30-\mathrm{mg} \mathrm{I}_{2} / \mathrm{g} \mathrm{NaX}, 214-\mathrm{mg} \mathrm{I} \mathrm{I}_{2} / \mathrm{g} \mathrm{AgX}$, 26-mg $\mathrm{I}_{2} / \mathrm{g} \mathrm{PbX}$, and 45-mg $\mathrm{I}_{2} / \mathrm{g} \mathrm{CdX}$. The molecular iodine loading capacity of $\mathrm{AgX}$ at breakthrough (DF 200) varied inversely with temperature and 
superficial velocity and directly with bed depth. The three critical parameters (temperature, pressure of $\mathrm{NO}_{2}$, and water vapor) affected the $\mathrm{I}_{2}$-capacity of $\mathrm{AgX}$ in an interdependent manner. The $\mathrm{I}_{2}$-capacity decreased significantly at both $100^{\circ} \mathrm{C}$ and $200^{\circ} \mathrm{C}$ in the presence of $2 \% \mathrm{NO}_{2}$. The $I_{2}$-loading capacity decreased for increased temperature in the presence of $5 \%$ water vapor. The combined effects of $2 \% \mathrm{NO}_{2}$ and $5 \%$ water vapor resulted in increasing $\mathrm{I}_{2}$ loading at $200^{\circ} \mathrm{C}$ compared to $100^{\circ} \mathrm{C}$, but the water vapor-- $\mathrm{NO}_{2}$ effect generally decreased the bed capacity. An increase in any one of the parameters resulted in a decrease in $\mathrm{I}_{2}$ capacity. The smallest capacity reduction occurred when the temperature increased from 100 to $200^{\circ} \mathrm{C}$. The largest capacity reduction occurred for $100^{\circ} \mathrm{C}$ and $2 \% \mathrm{NO}_{2}$.

It has been noted in several studies $86,88,91$ that higher $\mathrm{CH}_{3} \mathrm{I}$ DFs and loading capacities can be obtained for feed gases containing $\mathrm{H}_{2} \mathrm{O}$ vapor when the $\mathrm{AgX}$ beds are heated to 150 to $200^{\circ} \mathrm{C}$. Based on the work of Staples et a1., ${ }^{90}$ an increase in temperature resulted in a small but significant decrease in $\mathrm{I}_{2}$ loading capacity. In actual plant operation, sufficient bed depth will have to be provided to balance the enhancing effect of temperature on $\mathrm{CH}_{3} \mathrm{I}$ collection vs the reducing effect on $\mathrm{I}_{2}$ capacity. Part of the loss in $\mathrm{I}_{2}$ capacity when temperature was raised may well have been due to the much higher than normal loading capacity obtained when beds were loaded to breakthrough. 90

Recycle tests 90 were made for three 5-cm-deep AgX beds. The beds were repetitively loaded with $\mathrm{I}_{2}$ and then stripped with $\mathrm{H}_{2}$ at temperatures of 400 to $600^{\circ} \mathrm{C}$. Best regeneration results. were obtained at temperatures of 400 and $500^{\circ} \mathrm{C}$ for which $\mathrm{I}_{2}$-loading capacity declined about twofold 
after five cycles. For regenerating at $600^{\circ} \mathrm{C}$, loading capacity decreased about a factor of 3 after only three cycles. Because of low cost and high-I 2 capacity, $\mathrm{PbX}$ was determined to be the most acceptable zeolite to trap HI at elevated temperatures during regeneration of AgIX beds. The desorbed $\mathrm{I}_{2}$ in the $\mathrm{H}_{2}$-stream was sorbed onto $\mathrm{PbX}$ at $150^{\circ} \mathrm{C}$ and $500-\mathrm{cm} / \mathrm{min}$ face velocity to an average loading capacity of $317-\mathrm{mg} \mathrm{I}_{2} / \mathrm{g} \mathrm{PbX}$. Although the stability of $\mathrm{PbIX}$ to temperature and leaching effects was not established, the $\mathrm{PbIX}$ solid is relatively inexpensive and offers some promise as a solid that can be converted to a form suitable for long-term burial (e.g., by encapsulation of the cannister containing the PbIX solid in concrete).

Ackley and Combs ${ }^{88}$ studied the utilization of silver- and metalexchanged zeolites to remove iodine species from simulated LMFBR fuel reprocessing off-gas (Fig. 3). A schematic of the general experimental layout for testing silver zeolite beds is shown in Fig. 3. Standard experimental conditions included temperatures of 100 and $200^{\circ} \mathrm{C}\left(\mathrm{CH}_{3} \mathrm{I}\right.$ trapping is enhanced at higher temperatures), $\mathrm{CH}_{3} \mathrm{I}$ and $\mathrm{I}_{2}$ feed concentrations of 100 to $140 \mathrm{mg} / \mathrm{m}^{3}, 3 \% \mathrm{H}_{2} \mathrm{O}\left(90 \%\right.$ relative humidity at $25^{\circ} \mathrm{C}$ ), face velocity of $12.0 \mathrm{~m} / \mathrm{min}$, and sorbent depth of $5.08 \mathrm{~cm}$. Efficient performance was defined by DFs for both $\mathrm{CH}_{3} \mathrm{I}$ and $\mathrm{I}_{2}$ greater than $10^{3}$, with loading not less than $5-\mathrm{mg} \mathrm{I} / \mathrm{cm}^{3}$. Based on these conditions and criteria, the following sorbent-temperature combinations were considered satisfactory: $27 \% \mathrm{AgX}\left(1 / 16-i n\right.$. pellets) at $200^{\circ} \mathrm{C}$, and $90 \% \mathrm{AgX}(1 / 16-i n$. pellets) at 100 and $200^{\circ} \mathrm{C}$. For higher loadings, $90 \% \mathrm{AgX}$ was effective at $100^{\circ} \mathrm{C}$ for loading $13-\mathrm{mg} \mathrm{I} / \mathrm{cm}^{3}$ and at $200^{\circ} \mathrm{C}$ for loading $20 \mathrm{mg} \mathrm{I} / \mathrm{cm}^{3}$. For a feed gas at $200^{\circ} \mathrm{C}$ and $0.14 \%$ relative humidity treated on $90 \% \mathrm{AgX}$ at $19.2 \mathrm{~m} / \mathrm{min}$, 


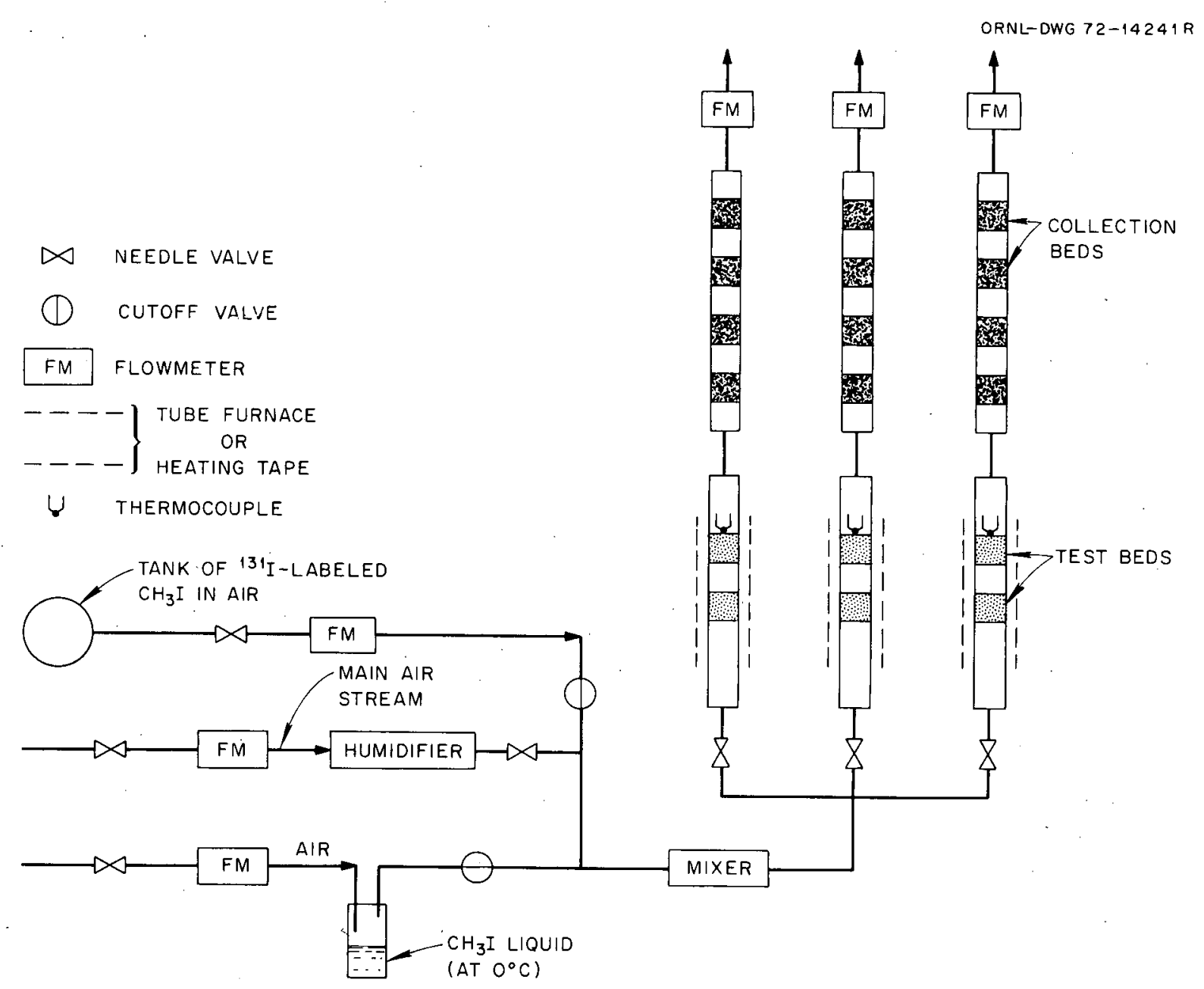

Fig. 3. Schematic of apparatus used to investigate the efficiency of various sorbents for trapping iodine in the form of methyl iodide at elevated temperatures. 
a DF of $10^{2}$ could be obtained for loading $178-\mathrm{mg} \mathrm{CH}_{3} \mathrm{I} / \mathrm{cm}^{3}$, and a $\mathrm{DF}$ of $10^{4}$ could be obtained for loading $74 \mathrm{mg} / \mathrm{cm}^{3}$. Other cations studied were $\mathrm{Li}, \mathrm{Na}, \mathrm{K}, \mathrm{Cu}, \mathrm{Mg}, \mathrm{Sr}, \mathrm{Ba}, \mathrm{Zn}, \mathrm{Cd}, \mathrm{Hg}, \mathrm{La}, \mathrm{Ce}, \mathrm{Pb}, \mathrm{Cr}, \mathrm{Mn}, \mathrm{Fe}, \mathrm{Co}$, and Ni. The most promising were potassium and cadmium preparations, but neither preparation was sufficient at a loading of $10-\mathrm{mg} \mathrm{I} / \mathrm{cm}^{3}$. When the operating temperature was reduced to $26^{\circ} \mathrm{C}$, DFs of $10^{4}$ and loadings of $11-\mathrm{mg} \mathrm{CH} \mathrm{CH}_{3} \mathrm{I} / \mathrm{cm}^{3}$ could be obtained on $90 \% \mathrm{AgX}$ in a dry atmosphere. However, for the same flow conditions, but with the inclusion of 3 vol \% $\mathrm{H}_{2} \mathrm{O}$, the $\mathrm{DF}$ of $\mathrm{CH}_{3} \mathrm{I}$ was very seriously reduced $(\geq 30)$, although the loading capacity remained about the same; the $I_{2}$ DF was not seriously affected by water vapor. The first part of Table 4 shows the Ackley and Combs data for the effects of relative humidity and increased temperature on DFs and the loading capacities that are obtained for $\mathrm{CH}_{3} \mathrm{I}$. The characteristics of $90 \% \mathrm{AgX}$ for trapping $\mathrm{CH}_{3} \mathrm{I}$ were not significantly affected by 10 vol $\% \mathrm{CO}_{2}$ in air, but exposure of the $\mathrm{AgX}$ to chlorine at $100^{\circ} \mathrm{C}$ reduced iodine trapping capacity. Also, exposure of the $90 \% \mathrm{AgX}$ to dodecane resulted in a temperature dependence in sorbing characteristics over the 100 to $450^{\circ} \mathrm{C}$ range.

Solid sorbent beds utilized for either cleanup of nuclear facility ventilation and building air or for iodine removal from fuel reprocessing off-gases would, according to present design criteria, undergo extended exposure to the off-gas flows. The most extensive, prolonged exposure tests for silver zeolites were conducted by Ackley and Davis ${ }^{93}$ in studying iodine species removal from simulated LMFBR fuel reprocessing off-gas. The conditions were: bed dimension, $2.67 \mathrm{~cm}$ ID by $5.08 \mathrm{~cm}$ long; superficial velocities of 14 to $19 \mathrm{~m} / \mathrm{min}$; $85 \%$ relative humidity at 
$26^{\circ} \mathrm{C}$ ( $\sim 3$ vol \%); dodecane concentrations, $1.5 \times 10^{-6} \mathrm{~g} / 1$ iter; nitric oxide, $1.2 \times 10^{-5} \mathrm{~g} /$ liter; $\mathrm{I}_{2}$ concentration, about $10 \mu \mathrm{g} / \mathrm{m}^{3} ; \mathrm{CH}_{3} \mathrm{I}$, about $2 \times 10^{5} \mu \mathrm{g} / \mathrm{m}^{3}$. Efficient sorbent trapping performance was defined as DFs for $\mathrm{CH}_{3} \mathrm{I}>9 \times 10^{3}$ and DFs for $\mathrm{I}_{2}>5 \times 10^{2}$. Based on the conditions and criteria described above, the following sorbent-temperature-exposure time combinations were considered satisfactory: (1) $26 \% \mathrm{AgX}, 1 / 16-\mathrm{in}$. pellets, at $200^{\circ} \mathrm{C}$, exposure times of 286 and 350 days; (2) $90 \% \mathrm{AgX}$, 1/16-in. pellets, $100^{\circ} \mathrm{C}$, exposure times of 195 and 259 days; (3) $88 \% \mathrm{AgX}$, 10 - to 20 -mesh beads, $200^{\circ} \mathrm{C}$, exposure times of 90 and 154 days. The exposure times are for $\mathrm{CH}_{3} \mathrm{I}$ and $\mathrm{I}_{2}$ respectively. At these experimental conditions, an $I_{2}$-feed concentration of $40 \mathrm{\mu g} / \mathrm{m}^{3}$ was equivalent to a loading capacity of $5 \mathrm{mg}$ of iodine per $\mathrm{cm}^{3}$ of sorbent per year in a 2.67 by $5.08-\mathrm{cm}$ bed. The useful life of an iodized activated charcoal, 8 to 16 mesh, (from WITCO) would be limited to 60 days or less at similar operating conditions.

\section{2 .4 Process capacity}

One of the major limitations to the use of AgX sorbents for the removal of iodine species is the deleterious effect that results from interaction of temperature and humidity. Pence et al. ${ }^{86}$ showed that for $\mathrm{I}_{2}$ removal from air containing $5 \times 10^{3}$ to $100 \times 10^{3} \mathrm{\mu g} / \mathrm{m}^{3}$, a $\mathrm{DF}$ of $10^{4}$ could be obtained at $22^{\circ} \mathrm{C}$ for a superficial velocity of $28 \mathrm{~m} / \mathrm{min}$, and a $100 \%$ relative humidity on a $5.08-\mathrm{cm}-1$ ong bed. Ackley and Combs 88 showed that when $I_{2}$ is removed from air containing $9.1-\mathrm{mg} \mathrm{I}_{2} / \mathrm{m}^{3}$, a $\mathrm{DF}$ of $10^{5}$ could be obtained (for a loading of $6.4-\mathrm{mg} \mathrm{I} / \mathrm{g} \mathrm{AgX}$ ) at $200^{\circ} \mathrm{C}$ for a superficial velocity of $19 \mathrm{~m} / \mathrm{min}$ and $3 \% \mathrm{H}_{2} \mathrm{O}(0.14 \%$ relative humidity) 
on a 5.08-cm-long bed. Ambient temperatures were not included in this study. In general, for $\mathrm{I}_{2}$ trapping, the $\mathrm{DF}$ obtained with $\mathrm{AgX}$ is not significantly different for gas feeds containing up to $3 \% \mathrm{H}_{2} \mathrm{O}$ at temperatures from 22 to $200^{\circ} \mathrm{C}$. There was a slight reduction in $\mathrm{I}_{2}$-loading capacity when the temperature was increased from 100 to $200^{\circ} \mathrm{C} .90$

However, when $\mathrm{CH}_{3} \mathrm{I}$ is removed from off-gases, the DF is drastically decreased for high relative humidities at ambient temperature. For example, a DF of only 27 was obtained for $\mathrm{CH}_{3} \mathrm{I}$ at $27^{\circ} \mathrm{C}$ for $90 \% \mathrm{AgX}$ in a $5.08-\mathrm{cm}$ bed, a superficial velocity of $12 \mathrm{~m} / \mathrm{min}$ and $3 \% \mathrm{H}_{2} \mathrm{O}(90 \%$ relative humidity). ${ }^{88}$ When the air was bone dry at $27^{\circ} \mathrm{C}$, the $\mathrm{CH}_{3} \mathrm{I} \mathrm{DF}$ at the same operating conditions increased to $10^{4}$. The loading capacity was about $10 \mathrm{mg} / \mathrm{cm}^{3}$ for both bone dry and $90 \%$ relative humidity feeds. Table 5 shows the range of conditions at elevated temperatures at which $\mathrm{AgX}$ is an excellent sorbent of $\mathrm{I}_{2}$ and $\mathrm{CH}_{3} \mathrm{I}$. The highest loading of 209-mg $\mathrm{CH}_{3} \mathrm{I} / \mathrm{g}$ AgX was achieved by Ackley and Combs. ${ }^{88}$ This high loading represented about $58 \%$ of the theoretical $\mathrm{CH}_{3} \mathrm{I}$ capacity.

More than 20 other cations ${ }^{88-91}$ have been investigated as replacements for the expensive $\mathrm{Ag}$ in the preparation of metal-exchanged zeolites. Only potassium and cadmium zeolites showed promise for removing iodine as $\mathrm{I}_{2}$ or $\mathrm{CH}_{3} \mathrm{I}$ from air streams. Ackley and Combs ${ }^{88}$ obtained DFs of about 50 at a loading of $10 \mathrm{mg} \mathrm{CH} \mathrm{CH}_{3} \mathrm{I} / \mathrm{cm}^{3}$ for using $\mathrm{CdX}$ to remove $\mathrm{CH}_{3} \mathrm{I}$ from an air feed at $200^{\circ} \mathrm{C}$ and 3 vol $\% \mathrm{H}_{2} \mathrm{O}$. However, DFs were very poor for $\mathrm{CH}_{3} \mathrm{I}$ removal with $\mathrm{CdX}$ from air streams at $27^{\circ} \mathrm{C}$ and 3 vol $\% \mathrm{H}_{2} \mathrm{O}$ (that is, condition of high relative humidity). Lead zeolite has been shown to be ineffective for $\mathrm{CH}_{3} \mathrm{I}$ removal but effective for $\mathrm{I}_{2}$ removal (however, its capacity for $\mathrm{I}_{2}$ is considerably less than that of $\mathrm{AgX}$ ). ${ }^{91}$ 
Table 5. General comparison of iodine sorption characteristics of $\mathrm{AgX}$ and the $\mathrm{Ag}-\mathrm{KTB}$ sorbent $\mathrm{a}, \mathrm{b}$

\begin{tabular}{lccccccc}
\hline Material & Ref. & $\begin{array}{l}\text { Iodine } \\
\text { species }\end{array}$ & $\begin{array}{c}\mathrm{H}_{2} \mathrm{O} \\
\text { concentration } \\
(\%)\end{array}$ & $\begin{array}{c}\mathrm{NO}_{2} \\
\text { concentration } \\
(\%)\end{array}$ & $\begin{array}{l}\text { Temp } \\
\left({ }^{\circ} \mathrm{C}\right)\end{array}$ & $\begin{array}{l}\frac{2}{\text { Loading species }} \\
\text { capacity }\end{array}$ & DF \\
\hline $\mathrm{AgX}$ & 86 & $\mathrm{CH}_{3} \mathrm{I}$ & 0 & 0 & 25 & 84 & $>10^{4}$ \\
$\mathrm{AgX}$ & 88 & $\mathrm{CH}_{3} \mathrm{I}$ & 3 & 0 & 200 & 209 & $>10^{2}$ \\
$\mathrm{AgX}$ & 88 & $\mathrm{CH}_{3} \mathrm{I}$ & 3 & 0 & 200 & 87 & $>10^{4}$ \\
$\mathrm{Ag}-\mathrm{KTB}$ & 94 & $\mathrm{CH}_{3} \mathrm{I}$ & 3 & 2.5 & 150 & 40 & $>10^{2}$ \\
$\mathrm{AgX}$ & 90 & $\mathrm{I}_{2}$ & 5 & 2 & 200 & 55 & $2 \times 10^{2}$ \\
\hline
\end{tabular}

${ }^{a}$ Silver content of $\mathrm{Ag}-\mathrm{KTB}$ is about $78-\mathrm{mg} \mathrm{Ag} / \mathrm{g} \mathrm{Ag}-\mathrm{KTB}$ as compared to $360-\mathrm{mg} \mathrm{Ag} / \mathrm{g} \mathrm{AgX}$. $\mathrm{Ag}-\mathrm{KTB}$ is available from Bayer, Federal Republic of Germany.

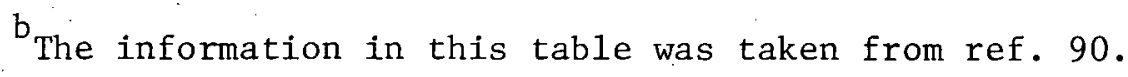


A serious deficiency of these three base metal zeolites is their inability to remove iodine from air streams which contain $\mathrm{NO}_{2}$ and water vapor. 5

\subsubsection{Present application}

Staples et ai. ${ }^{90}$ suggested the following proposed design for scaled-up utilization of $\mathrm{AgX}$ for iodine species removal from fuel reprocessing offgas:

Typical plant: Handling 1500 MTHM/year;

$$
\begin{aligned}
& 600 \mathrm{~kg} \text { iodine/year; } \\
& 140 \mathrm{~m}^{3} / \mathrm{min} .
\end{aligned}
$$

Assumption: Superficial velocity of $60 \mathrm{~m} / \mathrm{min}$, DF of $10^{3}$, and loading capacity of $50-\mathrm{mg} \mathrm{I}_{2} / \mathrm{g} \mathrm{AgX}$.

Bed dimensions: $1.71 \mathrm{~m}$ ID by $0.86 \mathrm{~m}$ long;

Loading time for one bed: 40 days;

Regeneration time for one bed: 4 days;

Number of recycles per year: 4 (20 to 30 recycles in 5 years).

For $600 \mathrm{~kg}$ of $\mathrm{I}_{2}$, about 2.5 metric tons of waste generated per year. However, this design requires the $\mathrm{AgX}$ to maintain an acceptable $\mathrm{I}_{2}$ loading capacity for 20 to 30 recycles. This capability was not demonstrated in the study (it was previously stated that regeneration at 400 and $500^{\circ} \mathrm{C}$ resulted in a twofold loss in capacity after five recycles). In plant slipstream tests, DFs greater than $10^{3}$ have been obtained for $\mathrm{CH}_{3} \mathrm{I}$ and $I_{2}$ removal from fuel reprocessing off-gases. In the Barnwell Plant of AGNS, silver zeolite was installed to act as a backup for the primary iodine-removal system, which is a $\mathrm{Hg}\left(\mathrm{NO}_{3}\right)_{2}-\mathrm{HNO}_{3} \mathrm{scrubber}$. 


\subsubsection{Advantages}

1. Silver zeolites exhibit low flammability and maintain iodine sorption efficiencies to $500^{\circ} \mathrm{C}$ and iodine retention capabilities to $1000^{\circ} \mathrm{C}$.

2. The $\mathrm{CH}_{3} \mathrm{I}$ removal efficiency and capacity of silver zeolites increase with temperature, with efficient sorption to $500^{\circ} \mathrm{C}$.

3. Silver zeolites present a low explosion hazard when used to treat air streams containing nitrogen oxides.

4. The final silver zeolite--iodine complex is a solid which has good handling properties.

5. The final silver zeolite--iodine complex is a solid which has the stability needed for long-term burial.

6. Silver zeolites have a high capacity for $\mathrm{CH}_{3} \mathrm{I}$ to 200-mg $\mathrm{CH}_{3} \mathrm{I} / \mathrm{g}$ sorbent.

7. The removal efficiency of silver zeolites for elemental iodine has been affected by very few contaminants.

8. Silver zeolites have been effective in reducing the iodine in waste streams to $\leq 10^{-10} \mathrm{mg} / \mathrm{m}^{3}$.

\subsubsection{Disadvantages}

1. Silver-exchanged zeolites are the most expensive of the solid sorbents which are candidates for adsorption of iodine species. They are 10 times as costly as the same volume of charcoal, about 20 times as costly as the same weight of charcoal, and 5 to 10 times as costly as the German Ag-KTB sorbent. 
2. The efficiency of silver zeolites for $\mathrm{CH}_{3} \mathrm{I}$ removal varies directly with temperature.

3. The removal efficiency of silver zeolites for $\mathrm{CH}_{3} \mathrm{I}$ is affected by $\mathrm{SO}_{2}, \mathrm{H}_{2} \mathrm{~S}$, propane, and $\mathrm{NO}_{2}$.

4. Standard silver zeolites are not acid resistant. Thus for off-gases containing high concentrations of water vapor and $\mathrm{NO}_{\mathrm{x}}$ gases, it is necessary to use Norton-type acidresistant zeolites.

5. There is some loss in capacity for elemental iodine at higher operating temperatures.

6. Much of the experimental work with $\mathrm{AgX}$ has been conducted in 2.54-cm-ID beds. Additional runs should be conducted with AgX beds of intermediate engineering scale to provide results useful for process scaleup (for example, 7.5 to 12.5cm-ID column of appropriate length).

3.3 Removal of Iodine Species from Gases by Utilizing Silver Nitrate-Impregnated, Amorphous Silicic Acid (Ag-KTB and AC 6120)

\subsubsection{Background}

The removal of iodine species from nuclear fuel reprocessing off-gases in the Federal Republic of Germany has been based on the development of nonregenerable solid sorbents having a high affinity and capacity for iodine. This sorbent is a $\mathrm{AgNO}_{3}$-impregnated, amorphous silicic acid, commonly called Ag-KTB, Ag-KTC, or AC-6120 (commercially available in Germany). 95 The different grades are indications of varying silver content. The normal range of silver content is 7 to $12 \mathrm{~g}$ of silver per 
$100 \mathrm{~g}$ of material. This material has been successfully utilized to process actual dissolver off-gas from the Karlsruhe Reprocessing Pilot Plant with efficiencies that satisfy the German environmental standards for iodine emissions.

\subsubsection{Chemical mechanisms}

The removal of iodine species on AC- 6120 beds occurs by conversion of the $\mathrm{AgNO}_{3}$ impregnant into the very insoluble silver iodide and silver iodate, ${ }^{94,96}$ which results in:

$$
\begin{aligned}
& \mathrm{AgNO}_{3(\mathrm{~s})}+\mathrm{I}_{2(\mathrm{~g})} \rightarrow \mathrm{AgI}(\mathrm{s})+\mathrm{INO}_{3(\mathrm{~s})} \\
& 2 \mathrm{INO}_{3(\mathrm{~s})}+\mathrm{AgNO}_{3(\mathrm{~s})} \rightarrow \mathrm{AgIO}_{3(\mathrm{~s})}+3 \mathrm{NO}_{2(\mathrm{~g})}+1 / 2 \mathrm{I}_{2(\mathrm{~g})} \\
& \mathrm{INO}_{3(\mathrm{~s})} \rightleftarrows \mathrm{NO}_{2(\mathrm{~g})}+1 / 2 \mathrm{O}_{2(\mathrm{~g})}+1 / 2 \mathrm{I}_{2(\mathrm{~g})} \cdot
\end{aligned}
$$

Silver iodide is also the product of the reactions between alkyl halides (e.g., methyl iodide) and the silver nitrate impregnant:

$$
\mathrm{AgNO}_{3}(\mathrm{~s})+\mathrm{R}-\mathrm{I}(\mathrm{g}) \rightarrow\left(\mathrm{NO}_{3} \cdot \mathrm{RI} \cdot \mathrm{Ag}\right)(\mathrm{s}) \rightarrow \mathrm{RNO}_{3}(\mathrm{~g})+\mathrm{AgI}(\mathrm{s})
$$

\subsubsection{Experimental results and engineering data useful for process design}

In 1970, Wilhelm and Schuettelkopf ${ }^{95}$ used $\mathrm{AgNO}_{3}$-impregnated amorphous silicic acid (Ag-KTC) to remove fission product iodine from gases at elevated temperatures and in oxidizing gases. This development was largely precipitated by the recognition that impregnated charcoal could not be used to remove fission product iodine from fuel reprocessing off-gases, because charcoal had a relatively low desorption temperature, a low-ignition temperature, and was relatively susceptible to poisoning. Normal operating parameters for these studies with the $\mathrm{Ag}-\mathrm{KTC}$ were: feed gas at $30^{\circ} \mathrm{C}$, 
$70 \%$ relative humidity $\left(3 \% \mathrm{H}_{2} \mathrm{O}\right)$, and $15 \mathrm{~m} / \mathrm{min}$; maximum 1 oading, 1 to 2 -mg $\mathrm{CH}_{3} \mathrm{I} / \mathrm{g} \mathrm{Ag}-\mathrm{KTC}$ for a feed concentration of $70-$ to $130-\mathrm{mg} \mathrm{CH}_{3} \mathrm{I} / \mathrm{m}^{3}$ (10 to $22 \mathrm{ppm}) ; 2-$ to $10-\mathrm{mg} \mathrm{I} / \mathrm{g} \mathrm{Ag-KTC}$ for a feed concentration of $20-$ to $250-\mathrm{mg} \mathrm{I} \mathrm{I}_{2}$ per $\mathrm{m}^{3}$ of air (1.9 to $\left.24 \mathrm{ppm}\right)$.

At standard operating conditions, the DFs for $\mathrm{CH}_{3} \mathrm{I}$ and $\mathrm{I}_{2}$ generally varied directiy with bed depth but inversely with relative humidity. When the silver content of the $\mathrm{Ag}-\mathrm{KTC}$ sorbent was varied from 20 to 180-mg Ag/g Ag-KTC, the DF varied directly with the degree of Agimpregnation. For a 10-cm-deep bed of 1 to $2 \mathrm{~mm} \mathrm{Ag-KTC} \mathrm{beads} \mathrm{with} \mathrm{a}$ silver content $\geq 78-\mathrm{mg} \mathrm{Ag} / \mathrm{g} \mathrm{Ag-KTC}$, the DFs for $\mathrm{CH}_{3} \mathrm{I}$ were $>10^{4}$. The $\mathrm{DF}$ for $\mathrm{CH}_{3} \mathrm{I}$ was $3 \times 10^{3}$ for a bed depth of $7.5 \mathrm{~cm}$, but $2 \times 10^{4}$ for a bed depth of $10 \mathrm{~cm}$. When superheated steam was the carrier gas for otherwise standard operating conditions, DFs for $\mathrm{CH}_{3} \mathrm{I}$ were $>10^{4}$ for a $10-\mathrm{cm}$ bed depth of $\mathrm{Ag}-\mathrm{KTC}$ with $7.8 \%$ silver. However, when the Ag-KTC material was soaked in water, practically no removal efficiency was measured for $\mathrm{CH}_{3} \mathrm{I}$ under otherwise standard conditions. For 10-cm-deep beds with residence times of $0.4 \mathrm{sec}$, DFs were reduced to $10^{2}$ to $10^{3}$ in the removal of $\mathrm{I}_{2}$ and $\mathrm{CH}_{3} \mathrm{I}$ from air- $\mathrm{NO}_{2}$ mixtures containing up to $10 \% \mathrm{NO}_{2}$ at $30^{\circ} \mathrm{C}$ and $70 \%$ relative humidity $\left(3 \% \cdot \mathrm{H}_{2} \mathrm{O}\right)$. Decontamination factors for $\mathrm{I}_{2}$. removal from air at $30^{\circ} \mathrm{C}$ and $70 \%$ relative humidity were $>10^{4}$ for $\mathrm{Ag}-\mathrm{KTC}$ at $7.8 \% \mathrm{Ag}$ content. However, an unknown iodine compound (possibly HOI) was detected for $I_{2}$ in wet air that was more penetrating than $\mathrm{CH}_{3} \mathrm{I}$. It was suggested that the negative effect of high humidity could be counteracted by heating the feed gas. The Ag-KTC material was assessed to be about three times more expensive than iodine-impregnated charcoal but about one-tenth the cost of standard AgX. 
Wilhelm ${ }^{97}$ reported that the respective surface area and porosity of the $\mathrm{Ag}-\mathrm{KTB}$ and $\mathrm{Ag}-\mathrm{KTC}$ materials were $110 \mathrm{~m}^{2} / \mathrm{g}$ and $700 \mathrm{~mm}^{3} / \mathrm{g}$, and $185 \mathrm{~m}^{2} / \mathrm{g}$ and $980 \mathrm{~mm}^{3} / \mathrm{g}$. Silver content was normally 6 . to $8 \%$ (60- to $80-\mathrm{mg} \mathrm{Ag} / \mathrm{g}$ KT material).* It was more desirable to use the $\mathrm{Ag}-\mathrm{KTB}$ material than Ag-KTC in reprocessing plants because of its higher mechanical strength and abrasion resistance. The removal efficiency of Ag-KTB sorbent was detrimentally affected by high relative humidity in the sweep gas. For air at atmospheric pressure, a temperature of $30^{\circ} \mathrm{C}$, superficial velocity of $15 \mathrm{~m} / \mathrm{min}$, and $\mathrm{CH}_{3} \mathrm{I}$ feed concentration of about $100 \mathrm{mg} / \mathrm{m}^{3}$, the $\mathrm{DF}$ of $\mathrm{CH}_{3} \mathrm{I}$ decreased from $10^{6}$ to $10^{2}$ when the humidity was increased from 20 to $80 \%$. To efficiently and economically remove $\mathrm{CH}_{3} \mathrm{I}$ with the $\mathrm{Ag}-\mathrm{KTB}$ material, the relative humidity of the feed gas should be limited to about $70 \%$ at 20 to $40^{\circ} \mathrm{C}$. When heating feed gas to avoid condensation of water and acid on the surface of the sorbents during processing of off-gases, a temperature of $150^{\circ} \mathrm{C}$ appeared to be the optimum operating point for a reprocessing plant iodine filter. For a feed gas at atmospheric pressure, a temperature of $150^{\circ} \mathrm{C}$ (relative humidity $0.9 \%$, 4.2 vol $\% \mathrm{H}_{2} \mathrm{O}$ ), and superficial velocity of $15 \mathrm{~m} / \mathrm{min}$, DFs were reduced slightly, from $10^{5}$ to $10^{4}$, when the $\mathrm{NO}_{2}$ concentration in the feed gas was increased from 1 to $10 \%$. The optimum granular size of the Ag-KTB sorbent was 1 to $2 \mathrm{~mm}$. The $\mathrm{DF}$ for $\mathrm{CH}_{3} \mathrm{I}$ showed a strong inverse variation with loading capacity, so that the DF decreased from $10^{4}$ for loading of 1 - to $10-\mathrm{mg} \mathrm{CH}_{3} \mathrm{I} / \mathrm{g} \mathrm{Ag}-\mathrm{KTB}$ to 25 for a loading of $41-\mathrm{mg} \mathrm{CH}_{3} \mathrm{I} / \mathrm{g}$ $\mathrm{Ag}-\mathrm{KTB}$. The $\mathrm{DF}$ for $\mathrm{I}_{2}$ also decreased as $\mathrm{I}_{2}$ loading capacity exceeded

* The $\mathrm{AgNO}_{3}$-impregnated $\mathrm{KTB}$ material is available from Bayer in Leverkusen, Germany, under the product number AC-6120. 
$20-\mathrm{mg} \mathrm{I}_{2} / \mathrm{g}-\mathrm{Ag}-\mathrm{KTB}$. Iodine could not be eluted from the $\mathrm{Ag}-\mathrm{KTB}$ sorbent by continuous air sparge at $300^{\circ} \mathrm{C}$ for 33 days. Irradiation to $8.6 \times 10^{8}$ rads caused no significant changes in iodine DFs on $\mathrm{Ag}-\mathrm{KTB}$. Finally, when $\mathrm{Ag}-\mathrm{KTB}$ samples were exposed to actual off-gas in a fuel reprocessing plant, DFs were $>10^{3}$ for dissolver off-gas but lower for solvent and waste tank off-gas.

Wilhelm et a1. ${ }^{94}$ recently reported on the status of application of $\mathrm{AgNO}_{3}$-impregnated amorphous silicic acid for iodine species removal from off-gases at the Karlsruhe Reprocessing Pilot Plant. Included in the study were discussions of the flowsheet for dissolver off-gas (DOG) cleaning, the reaction of different organic iodine compounds with the sorbent bed and the effect of such reactions on $\mathrm{CH}_{3} \mathrm{I}$ and $\mathrm{I}_{2}$ removal, the effects of various sorbent-bed poisons, and the loading capacity and removal efficiency of the solid sorbent for dissolver off-gas before and after $\mathrm{NO}_{2}$ removal. If the iodine can be removed directly from the dissolver off-gas stream before $\mathrm{NO}_{2}$ removal, the volatilization of iodine from the $\mathrm{NO}_{2}$ scrubber is avoided, and the concentration of $\mathrm{NO}_{2}$ scrubber acid is simplified.

A serious reduction in the $\mathrm{I}_{2}$ and $\mathrm{CH}_{3} \mathrm{I}$ removal efficiencies resulted when $\mathrm{AC}-6120$ (or $\mathrm{Ag}-\mathrm{KTB}$ ) was used to treat the vessel off-gas from the reprocessing pilot plant. This was attributed to the conversion of $\mathrm{AgNO}_{3}$ to $\mathrm{Ag}_{2} \mathrm{O}$ caused by the reducing effect of organic impurities in the vessel off-gas (VOG). It was later determined that the impairment of operation and the discoloration due to the VOG could be eliminated by using a $\mathrm{NO}_{2}-$ air sweep. Thus the $\mathrm{NO}_{2}$ had a beneficial effect on the function of the AC- 6120 bed. To avoid the contamination effect in actual feul reprocessing 
operations, it was recommended that $\mathrm{NO}_{2}$-bearing dissolver off-gas should be cleaned in a first-step iodine sorption filter and then mixed with the VOG upstream of the iodine sorption filter installed for the VOG. Experimental results obtained for high-loading tests with $I_{2}$, including 1 to $5 \% \mathrm{NO}_{2}$ in humid air, are shown in Table 6 . Shown in Fig. 4 is a schematic of the facility for testing beds of $\mathrm{AC}-6120 / \mathrm{H}_{1}$ to determine their capacity to sorb iodine from the dissolver off-gas of the Karlsruhe Reprocessing Plant.

Correlations for engineering scale-up. No correlations have been developed to specify design criteria for scaling up applications of the AC-6120 material.

\subsubsection{Present applications}

A filter bed of $26 \mathrm{~kg}$ of low-impregnated $\mathrm{AC}-6120$ (7\% $\mathrm{Ag}$ ) was utilized in the Karlsruhe Reprocessing Plant (WAK) in 1975. Operating conditions included an average dissolver off-gas flow rate of $148 \mathrm{~m}^{3} / \mathrm{hr}$, giving a residence time of $1.0 \pm 0.4 \mathrm{sec}$, at a temperature of $130^{\circ} \mathrm{C}$. The average NO $x$ concentration in the off-gas was $\leq 2$ vol \%, with peaks of 20 vol $\%$. Based on ${ }^{129} \mathrm{I}$ analysis in influent and effluent streams, the DF of the iodine sorption (primarily for $\mathrm{I}_{2}$, because there would be very little organic iodide) ranged from $1.0 \pm 0.4 \times 10^{4}$ to $2.0 \pm 0.5 \times 10^{4}$ over 120 days of service life of the filter. At the cessation of the operation, total sorbed iodine was $21.3 \mathrm{~kg} \mathrm{I}$, which comprised about $60 \%$ of the capacity of the solid-sorbent filter AC-6120.

The design of a large reprocessing plant will be very similar to that of the WAK. A two-stage solid-sorbent filter will be used in which 
Table 6. Use of silver nitrate-impregnated silicic acid (AC-6120/ $\left.\mathrm{H}_{1}\right)^{a}$ to remove elemental iodine from simulated fuel reprocessing off-gases. Laboratory tests at bed depths comparable to those proposed for a large reprocessing plant ${ }^{b}$

\begin{tabular}{lccccc}
\hline $\begin{array}{c}\text { Conditions } \\
\left.\text { (dew point, } 30^{\circ} \mathrm{C}\right)\end{array}$ & $\begin{array}{c}\text { Bed } \\
\text { depth } \\
(\mathrm{cm})\end{array}$ & $\begin{array}{c}\text { Superficial } \\
\text { velocity } \\
(\mathrm{cm} / \mathrm{sec})\end{array}$ & $\begin{array}{c}\text { Removal } \\
\text { efficiency } \\
(\%)\end{array}$ & $\mathrm{DF}$ & $\begin{array}{c}\text { Loading } \\
\left(\mathrm{g} \mathrm{I} \mathrm{I}_{2}\right)\end{array}$ \\
\hline $\begin{array}{l}\text { Humid air }+1 \% \mathrm{NO}_{2} \% \\
150^{\circ} \mathrm{C}\end{array}$ & 10 & 25 & 99.9998 & $5 \times 10^{4}$ & 18.1 \\
$\begin{array}{l}\mathrm{Humid} \text { air }+2.5 \% \mathrm{NO}_{2}, \\
150^{\circ} \mathrm{C}\end{array}$ & 10 & 25 & 99.9987 & $7.6 \times 10^{4}$ & 18.1 \\
$\begin{array}{l}\mathrm{Humid} \text { air }+5.0 \% \mathrm{NO}_{2}, \\
150^{\circ} \mathrm{C}\end{array}$ & 10 & 25 & 99.9997 & $3 \times 10^{5}$ & 18.1 \\
$\begin{array}{l}\mathrm{Humid} \text { air }+5.0 \% \mathrm{NO}_{2}, \\
120^{\circ} \mathrm{C}\end{array}$ & 10 & 25 & 99.9998 & $5 \times 10^{5}$ & 18.1 \\
\hline
\end{tabular}

${ }^{\mathrm{a}} \mathrm{AC}-6120 / \mathrm{H}_{1}$ is a highly impregnated form of $\mathrm{AC}-6120$, containing up to $12 \mathrm{wt} \% \mathrm{Ag}$, whereas AC-6120 normally contained 7 to 8 wt \% Ag; grain size, 1 to $2 \mathrm{~mm}$.

$\mathrm{b}$ The information in this table was taken from ref. 94.

${ }^{\mathrm{C}}$ Relative humidity of $1.0 \%, 4.0$ vol $\% \mathrm{H}_{2} \mathrm{O}$ at $30^{\circ} \mathrm{C}$. 
ORNL-DWG $78-13792$

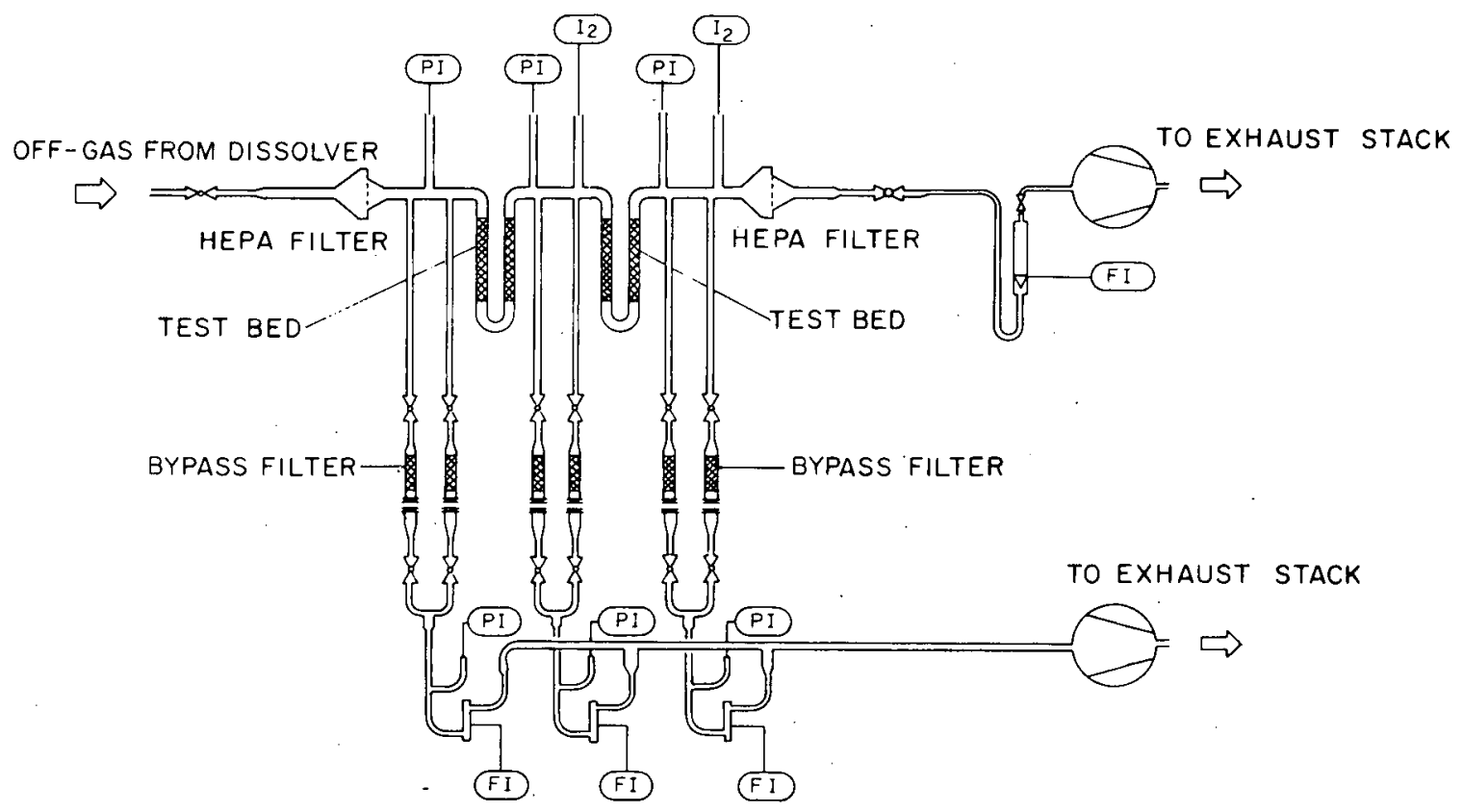

Fig. 4. Schematic of test equipment for sorption of iodine from the dissolver off-gas of the Karlsruhe Reprocessing Plant (WAK). 
the first stage will be loaded until breakthrough; the backup filter will then be loaded to breakthrough while a fresh filter drum is being readied in the first stage for a second loading. A filter must be replaced every 6 days to maintain nominal operation in a large reprocessing plant. It is planned that the filter elements will be included for disposal in 200-1iter iron-hooped drums that will probably be further cemented in 400-1iter drums for long-term burial in a high-activity waste burial ground. The long-term stability of iodine-loaded $A C-6120 / \mathrm{H}_{1}$ in salt deposits still must be determined.

\subsubsection{Process capacity}

As much as $60 \%$ of the $\mathrm{Ag}$ in the $\mathrm{AC}-6120$ sorbent beds was reacted in actual pilot plant tests. In $\mathrm{AC}-6120 / \mathrm{H}_{1}$ with a $12 \% \mathrm{Ag}$ content, 143

$\mathrm{g}$ of ${ }^{129} \mathrm{I}$ can theoretically be removed with $1 \mathrm{~kg}$ of sorbent, based on $100 \%$ reaction of the $\mathrm{AgNO}_{3}$ with iodine $\left(\mathrm{I}_{2}\right)$; however, the capacity should be 1 imited to 1 to $10 \mathrm{mg} \mathrm{CH}_{3} \mathrm{I} / \mathrm{g}$ of $\mathrm{AC}-6120 / \mathrm{H}_{1}$.

\subsubsection{Process advantages}

1. Iodine is bound to a sorbent with a high affinity, producing a complex suitable for long-term waste disposal.

2. Iodine sorption with Ag-KTB provides a high-percentage utilization of the silver impregnant.

3. The cost of $\mathrm{Ag}-\mathrm{KTB}$ is attractive, being about one-tenth that of silver zeolite for equivalent removal efficiencies and operational characteristics.

4. The Ag-KTB material has been used with actual dissolver LWR-fuel-reprocessing off-gas, where it was determined 
that for DOG only, the filter was not affected by $\mathrm{NO}_{\mathrm{x}}$; it could therefore be located either before or after the $\mathrm{NO}_{\mathrm{x}}$ scrubbing step.

5. The presence of $\mathrm{NO}_{2}$ actually has a beneficial effect in protecting the $\mathrm{Ag}-\mathrm{KTB}$ sorbent from organic poisoning produced by organics in the vessel off-gases.

6. The capability of locating the Ag-KTB filter prior to acid scrubbing simplifies acid recovery and iodine volatilization of the $\mathrm{NO}_{2}$ scrubber bottoms.

7. In air of $70 \%$ relative humidity (about $4 \% \mathrm{H}_{2} \mathrm{O}$ ), and with superheated steam at $150^{\circ} \mathrm{C}$, the $\mathrm{Ag}-\mathrm{KTB}$ sorbent showed good removal of $\mathrm{CH}_{3} \mathrm{I}$.

8. Solid filters can be handled in canisters in remote operation at an actual reprocessing plant.

\subsubsection{Process disadvantages}

1. The Ag-KTB sorbent appears to be adversely affected by organics in the absence of $\mathrm{NO}_{\mathrm{x}}$.

2. The Ag-KTB is very seriously affected by a dew-point temperature excursion.

\subsection{Removal of Iodine Species from Gases by Utilizing Silver and Lead Mordenites}

\subsubsection{Background}

The necessity of developing an alternative to $\mathrm{AgX}$ as a sorbent for removal of iodine species from off-gases arose because of several observations. Preliminary cost analyses have indicated that silver-exchanged 
zeolite type-13X ( $\mathrm{AgX})$ sorbents would be very expensive to use in the removal of iodine from gases if they could not be regenerated. Additionally, no efficient alternate metal-exchanged zeolite material has been developed. Finally, the standard AgX material was affected deleteriously by acidic gases. Lewis ${ }^{98}$ has shown that the Norton-Zeolon molecular-sieve material was superior in acid resistance to the standard Linde $13 \mathrm{X}, 5 \mathrm{~A}$, and $4 \mathrm{~A}$ molecular-sieve material. Pence and Thomas ${ }^{99}$ have shown that the Zeolon mordenites (synthetic hydrogen and sodium mordenites) maintain sufficient integrity in the presence of $\mathrm{NO}_{\mathrm{x}}$ so that they may be used to catalyze the ammonia reduction of $\mathrm{NO}_{\mathrm{x}}$-bearing off-gases. Catalytic operation was at 350 to $400^{\circ} \mathrm{C}$ for feed streams of air containing $5000-\mathrm{ppm} \mathrm{NO}$ and humidified with a dew point to $46^{\circ} \mathrm{C}\left(9\right.$ to 10 vol $\left.\% \mathrm{H}_{2} 0\right)$. Leist et al. 100 later extended the use of the mordenites as a catalyst for $\mathrm{NO}_{\mathrm{x}}$ reduction to the pilot plant scale. The Zeolon mordenites are specifically acidresistant sieves containing calcium and potassium in addition to the usual sodium found in ordinary zeolites. A major constituent of Zeolon is a proprietary acid-resistant binder. ${ }^{101}$

\subsubsection{Chemical mechanisms}

The chemical reactions between mordenites, molecular iodine, and organic iodides have not yet been fully explained. However, it has been reported that preexposure of the silver-exchanged mordenite Zeolon $900(\mathrm{AgZ})$ to air at a temperature of $100^{\circ} \mathrm{C}$ decreased the capacity of that material for $I_{2}$. An attempt was made to explain this capacity reduction based on an equilibrium such as

$$
\mathrm{Ag}_{2} \mathrm{O}(\mathrm{S}) \stackrel{\rightarrow}{\leftarrow} \mathrm{Ag}(\mathrm{S})+1 / 2 \mathrm{O}_{2}(\mathrm{~S})
$$


Thus hydrogen pretreatment would reduce the oxygen effect by protonating the oxygen anion, thereby reducing the Ag to the metallic state. The reaction between $I_{2}$ and the silver zeolites is probably very similar to the reaction between $I_{2}$ and the standard 13X-based AgX sorbents. The reaction between $\mathrm{I}_{2}$ and $\mathrm{PbX}$ in the presence of $\mathrm{H}_{2}$ has not been elaborated, but it is generally assumed that lead iodide is formed.

\subsubsection{Experimental results and engineering data useful for process design}

Experimental results. Initial studies were conducted by Slansky et a1. 102,103 to develop a regenerable sorbent system based on synthetic zeolites, which would offset the economic disadvantages of once-through use of silver-based zeolites. It was determined that $\mathrm{I}_{2}$ sorbed as $\mathrm{AgI}$ with a silver-exchanged zeolite $(\mathrm{AgX})$ could be desorbed as $\mathrm{HI}$ (at $500^{\circ} \mathrm{C}$ ) and chemisorbed with a following lead-exchanged zeolite ( $\mathrm{PbX}$ ) in a pure hydrogen stream. The successful operation of the tandem process would provide for the economic sorption of iodine, because the iodine would first be collected on the regenerable AgX bed. It would then be eluted from that bed into a second $\mathrm{PbX}$ bed that had the desirable characteristics of being inexpensive and able to complex the iodine into a product with the stability needed for long-term storage.

However, the silver-exchanged mordenite Zeolon $900(\mathrm{AgZ})^{*}$ is apparently superior to $\mathrm{AgX}$, both because of a greater stability when exposed to acidic

\footnotetext{
* The silver-exchanged mordenite in an untreated state is normally designated by $\mathrm{AgZ}$. However, pretreatment of the $\mathrm{AgZ}$ with $\mathrm{H}_{2}$ at $500^{\circ} \mathrm{C}$ for $24 \mathrm{hr}$ prior to utilization reduces the silver to the metallic state, which is designated by $\mathrm{Ag}^{\circ} \mathrm{Z}$. The mordenite as $\mathrm{Ag}^{\circ} \mathrm{Z}$ always showed a higher iodine capacity than did the unreduced $\mathrm{AgZ}$.
} 
vapors, and in maintaining its loading capacity and removal efficiency in cycling operation. The loading capacity of the silver-exchanged-mordenite 900 (not reduced with hydrogen prior to use) for molecular iodine was

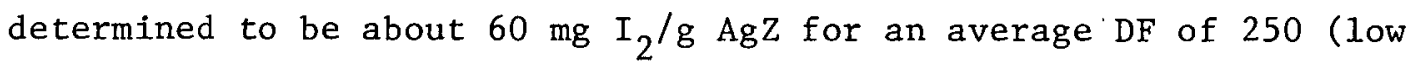
because of loading until breakthrough). It had the following operating conditions: ${ }^{103}$ bed depth, $5 \mathrm{~cm}$; superficial face velocity, $15 \mathrm{~m} / \mathrm{min}$; mesh size, 10 to 20 ; bed temperature, $100^{\circ} \mathrm{C}$; carrier gas, dry air. The loading rate for the $\mathrm{AgZ}$ bed was about $0.44 \mathrm{mg} \mathrm{I}_{2} \mathrm{~min}^{-1} \mathrm{~cm}^{-2}$, whereas the regenerating desorption rate was about ten times the loading rate. The loading capacity of the $\mathrm{AgZ}$ for binding $\mathrm{I}_{2}$ was reduced by at least $50 \%$ for dry air at $100^{\circ} \mathrm{C},{ }^{104}$ but this effect was eliminated by a following equilibration with hydrogen. Much of the loading capacity can also be retained without $\mathrm{H}_{2}$ pretreatment by raising the test temperature to $150^{\circ} \mathrm{C}$.

The effects of water vapor, bed temperature, $\mathrm{NO}$, and $\mathrm{NO}_{2}$ on the iodine capacity of silver-exchanged mordenite, $\mathrm{Ag}^{\circ} \mathrm{Z}$, with silver in the metallic state, were studied for the following conditions: bed diameter, $5 \mathrm{~cm}$; bed depth, $15 \mathrm{~cm}$; bed weight, $270 \mathrm{~g}$; superficial face velocity, $15 \mathrm{~m} / \mathrm{min}$; bed temperature, $150^{\circ} \mathrm{C} ; \mathrm{I}_{2}$ concentration in air, $1500 \mathrm{mg} \mathrm{I} 2 / \mathrm{m}^{3}$; DF at breakthrough, $10^{3}$ to $10^{4} .105$ The maximum loading capacity for $I_{2}$ was obtained when the silver-exchanged mordenite $\mathrm{AgZ}$ was pretreated with $\mathrm{H}_{2}$ at $500^{\circ} \mathrm{C}$ and 5 liters/min for $24 \mathrm{hr}$ (resulting in $\mathrm{Ag}^{\circ} \mathrm{Z}$ ). Maximum $\mathrm{I}_{2}-$ loading capacity for simulated DOG streams containing $6 \% \mathrm{H}_{2} \mathrm{O}, 2 \% \mathrm{NO}_{2}$, and $2 \%$ NO was an average loading of $119 \pm 12 \mathrm{mg} \mathrm{I} / 2 / \mathrm{Ag}^{\circ} \mathrm{Z}$ for the total 15-cm

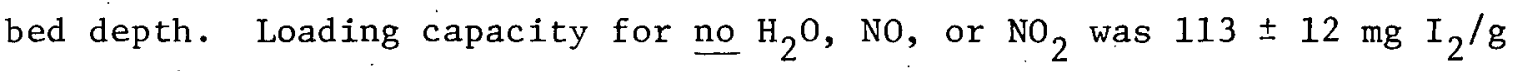
$\mathrm{Ag}^{\circ} \mathrm{Z}$. The addition of only No to the feed gas resulted in an increase 
in $\mathrm{I}_{2}$ loading of the $\mathrm{Ag}^{\circ} \mathrm{Z}$ from $113 \pm 12$ to $129 \pm 10 \mathrm{mg} \mathrm{I} / \mathrm{g} \mathrm{Ag}{ }^{\circ} \mathrm{Z}$. The addition of only $\mathrm{NO}_{2}$ to the feed gas resulted in a decrease in $\mathrm{I}_{2}$ loading of $\mathrm{Ag}^{\circ} \mathrm{Z}$ to $68 \pm 12 \mathrm{mg} \mathrm{I} 2 / \mathrm{g} \mathrm{Ag}^{\circ} \mathrm{Z}$. It was speculated that the effect of NO and $\mathrm{NO}_{2}$ on $\mathrm{Ag}^{\circ} \mathrm{Z}$ might be due to an equilibrium such as

$$
2 \mathrm{Ag}^{\circ}(\mathrm{s})+\mathrm{NO}_{2}(\mathrm{~g}) \stackrel{\rightarrow}{\leftarrow} \mathrm{Ag}_{2} \mathrm{O}(\mathrm{s})+\mathrm{NO}(\mathrm{g}),
$$

where NO acts as a reductant even in the presence of $\mathrm{O}_{2}$ to maintain the silver in a metallic state. The presence of $\mathrm{NO}_{2}$ alone might slowly oxidize silver to $\mathrm{Ag}_{2} \mathrm{O}$ with a resulting reduction in iodine loading. The presence of $\mathrm{NO}_{2}$ with $\mathrm{NO}$ and $\mathrm{H}_{2} \mathrm{O}$ resulted in very little change in the $\mathrm{I}_{2}$ capacity of the $\mathrm{Ag}^{\circ} \mathrm{Z}$. The large interaction noted between NO and $\mathrm{NO}_{2}$ apparently negated the effects of $\mathrm{NO}_{2}$ alone. The $\mathrm{I}_{2}$ loading capacity of $\mathrm{AgZ}$ (silver not in reduced form) was about half of the $\mathrm{I}_{2}$ capacity of $\mathrm{Ag}^{\circ} \mathrm{Z}$ (69 mg $\mathrm{I}_{2} / \mathrm{g} \mathrm{AgZ}$ vs $124 \pm 17 \mathrm{mg} \mathrm{I} 2 / \mathrm{g} \mathrm{Ag}^{\circ} \mathrm{Z}$ ). No significant reduction was observed in iodine loading on $\mathrm{Ag}^{\circ} \mathrm{Z}$ for simulated of $\dot{f}$-gases containing up to $6 \%$ water vapor and varying in temperature from 100 to $250^{\circ} \mathrm{C}$.

After loading and regeneration of $\mathrm{a} \mathrm{Ag}^{\circ} \mathrm{Z}$ bed for 13 cycles, the average loading of the first eight cycles was in the range 117 to 140 mg $I_{2} / \mathrm{g} \mathrm{Ag}^{\circ} \mathrm{Z}$, but the $\mathrm{I}_{2}$ loading was reduced in the last five cycles to

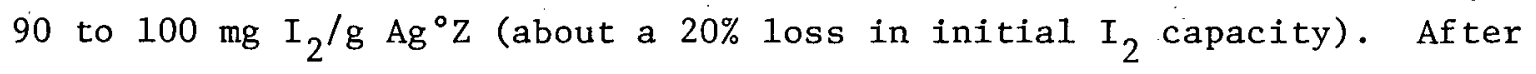
the seventh cycle, it was necessary to double the regeneration time to $32 \mathrm{hr}$ to achieve greater than $90 \%$ iodine removal. Extrapolation of the data indicated that no less than $20 \%$ loss and no greater than $50 \%$ loss in the loading capacity would occur after 18 cycles. Apparently, using either $\mathrm{PbIZ}$ or $\mathrm{PbIX}$ for final collection and storage of ${ }^{129}$ I would be economically superior to storage of ${ }^{129} \mathrm{I}$ on $\mathrm{Ag}^{\circ} \mathrm{Z}$. 
Based on instantaneous DF loading capacity for $I_{2}$, the optimum bed temperature for HI chemisorption on lead-exchanged zeolites seemed to be in the range 100 to $150^{\circ} \mathrm{C}$. Further studies are probably necessary to delineate the optimum loading temperature for $\mathrm{PbZ}$. About $70 \%$ of iodine eluted from AgIZ beds and loaded onto NaIX beds was bound by undesirable and unstable physisorption to the NaX. The $\mathrm{I}_{2}$ loading on $\mathrm{Pb}^{\circ} \mathrm{X}$ was about one-half that of $\mathrm{PbX}$ and $\mathrm{PbZ}$. However, the unexpected poor loading capacity of $\mathrm{Pb}^{\circ} \mathrm{X}$ was attributed to pore collapse during preparation at $500^{\circ} \mathrm{C}$ in hydrogen. Iodine loading of $408-\mathrm{mg} \mathrm{I}_{2} / \mathrm{g} \mathrm{PbX}$ was obtained with iodine vapor pressures less than $4 \times 10^{-8}$ atm. The lead-exchanged mordenite with lead in the metallic state $\left(\mathrm{Pb}^{\circ} \mathrm{Z}\right)$ may provide the best combination of high- $\mathrm{I}_{2}$ loading and low-iodine vapor pressure for all of the zeolite-mordenite sorbents that were studied for final iodine sorption and storage.

It has been reported 90,106 that the chemisorption of $\mathrm{I}_{2}$ in $\mathrm{PbX}$ doesn't appear to be thermodynamically favored. However, the reaction between $\mathrm{PbO}$ and $\mathrm{HI}$ is favored, so that for $\mathrm{H}_{2}$ carrier gas, and the absence of $\mathrm{O}_{2}$, the chemisorbed $\mathrm{PbI}_{2}\left(\mathrm{PbI}_{2} \mathrm{X}\right)$ is stable at $150^{\circ} \mathrm{C}$. The $\mathrm{PbI}_{2} \mathrm{X}$ apparently remains kinetically stable in air after cooling to room temperature.

\subsubsection{Present applications}

An integrated small-scale system ${ }^{105}$ containing two regenerable $\mathrm{Ag}^{\circ} \mathrm{Z}$ beds and a follow-up $\mathrm{PbX}$ bed for final sorption of the $\mathrm{I}_{2}$ eluted from the $\mathrm{Ag}^{\circ} \mathrm{Z}$ beds, has been utilized to treat simulated LWR fuel reprocessing dissolver off-gas. The operating conditions for this 
integrated system are shown in Table 7. Although scale-up criteria must be obtained to ensure that the same results can be obtained for a full-scale reprocessing plant, the performance of the small-scale system has been very promising. The DFs produced were $10^{4}$ to $10^{5}$ for $\mathrm{I}_{2}$ removal from simulated $\mathrm{DOG}$ gases containing up to $2 \% \mathrm{NO}_{2}$ and $2 \%$ No. Operation was continued until the first $5 \mathrm{~cm}$ of the $15-\mathrm{cm}-\mathrm{deep} \mathrm{Ag}^{\circ} \mathrm{Z}$ beds were essentially saturated with $\mathrm{I}_{2}$. Utilization of the $\mathrm{Ag}^{\circ} \mathrm{Z}$ in the saturation zone was $280 \%$ of the $237 \mathrm{mg} \mathrm{I} 2 / \mathrm{g} \mathrm{Ag}^{\circ} \mathrm{Z}$ capacity. After 5 recycles of the $\mathrm{Ag}^{\circ} \mathrm{Z}$ bed, virtually no reduction in elemental iodine loading was observed. The iodine eluted from the $\mathrm{Ag}^{\circ} \mathrm{Z}$ bed was successfully sorbed onto the $\mathrm{PbX}$ disposable bed during regeneration of the $\mathrm{Ag}^{\circ} \mathrm{Z}$ bed, and about $90 \%$ of the $\mathrm{PbX}$ was utilized ( $400 \mathrm{mg} \mathrm{I}_{2} / \mathrm{g} \mathrm{PbX}$ ). Figure 5 is a schematic which shows the arrangement of operating equipment and beds of $\mathrm{Ag}^{\circ} \mathrm{Z}$ and $\mathrm{PbX}$ for removing iodine from off-gas.

\subsubsection{Process capacity}

The maximum loading for full saturation of the bed was about $190 \mathrm{mg}$ $\mathrm{I}_{2} / \mathrm{g} \mathrm{Ag}^{\circ} \mathrm{Z}$, which is about $80 \%$ utilization of the available $\mathrm{Ag}$ ( $25 \%$ of the sorbent substrate). The maximum loading on the lead zeolite was $400 \mathrm{mg} \mathrm{I} / \mathrm{g} \mathrm{PbX}$.

\subsubsection{Process advantages}

Many of the advantages cited for zeolites are also valid for mordenites. However, mordenites have additional advantages relative to zeolites when utilized to remove elemental iodine from off-gases: 
Table 7. Operational conditions used to test the effect of hydrogen recycle on the capacity of reduced silver zeolon $\left(\mathrm{Ag}^{\circ} \mathrm{Z}\right)$ beds for reaction with elemental iodine ${ }^{a}$

Bed parameters: diam, $5 \mathrm{~cm}$; depth, $15 \mathrm{~cm}$; particle size, 10 to 20 mesh; superficial face velocity, $15 \mathrm{~m} / \mathrm{min}$

\begin{tabular}{|c|c|c|}
\hline Experimental parameter & Iodine loading & Iodine stripping \\
\hline Inlet pressure, mm $\mathrm{Hg}$ & 700 & 760 \\
\hline Carrier gas & Air & Hydrogen \\
\hline Bed temperature, ${ }^{\circ} \mathrm{C}$ & 150 & 500 \\
\hline $\begin{array}{l}\text { Iodine concentration at } 21^{\circ} \mathrm{C} \\
\text { and } 1 \mathrm{~atm}, \mathrm{mg} / \mathrm{m}^{3}\end{array}$ & $1500^{b}$ & 7400 \\
\hline $\mathrm{NO}_{2}$ concentration, $\%$ & 2 & 0 \\
\hline NO concentration, $\%$ & 2 & 0 \\
\hline Dew point, ${ }^{\circ} \mathrm{C}$ & 35 & $\mathrm{Ni1}$ \\
\hline $\begin{array}{l}\text { Iodine flux to and from bed, } \\
\text { mg min-1 } \mathrm{cm}^{-2}\end{array}$ & $1.5^{\mathrm{c}}$ & 4.5 \\
\hline Decontamination factor & $10^{4}-10^{5}$ & \\
\hline
\end{tabular}

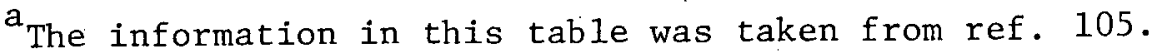

${ }^{b}$ Actual DOG concentration is anticipated to be $4400 \mathrm{mg} \mathrm{I}_{2} / \mathrm{m}^{3}$ (38 $\mathrm{ppm}$ ); $1500 \mathrm{mg} \mathrm{I} \mathrm{I}_{2} / \mathrm{m}^{3}$ is $142 \mathrm{ppm}$.

$c_{\text {Actual DOG iodine } \mathrm{flux} \text { would be about } 0.4 \mathrm{mg} \mathrm{min}}^{-1} \mathrm{~cm}^{-2}$. 


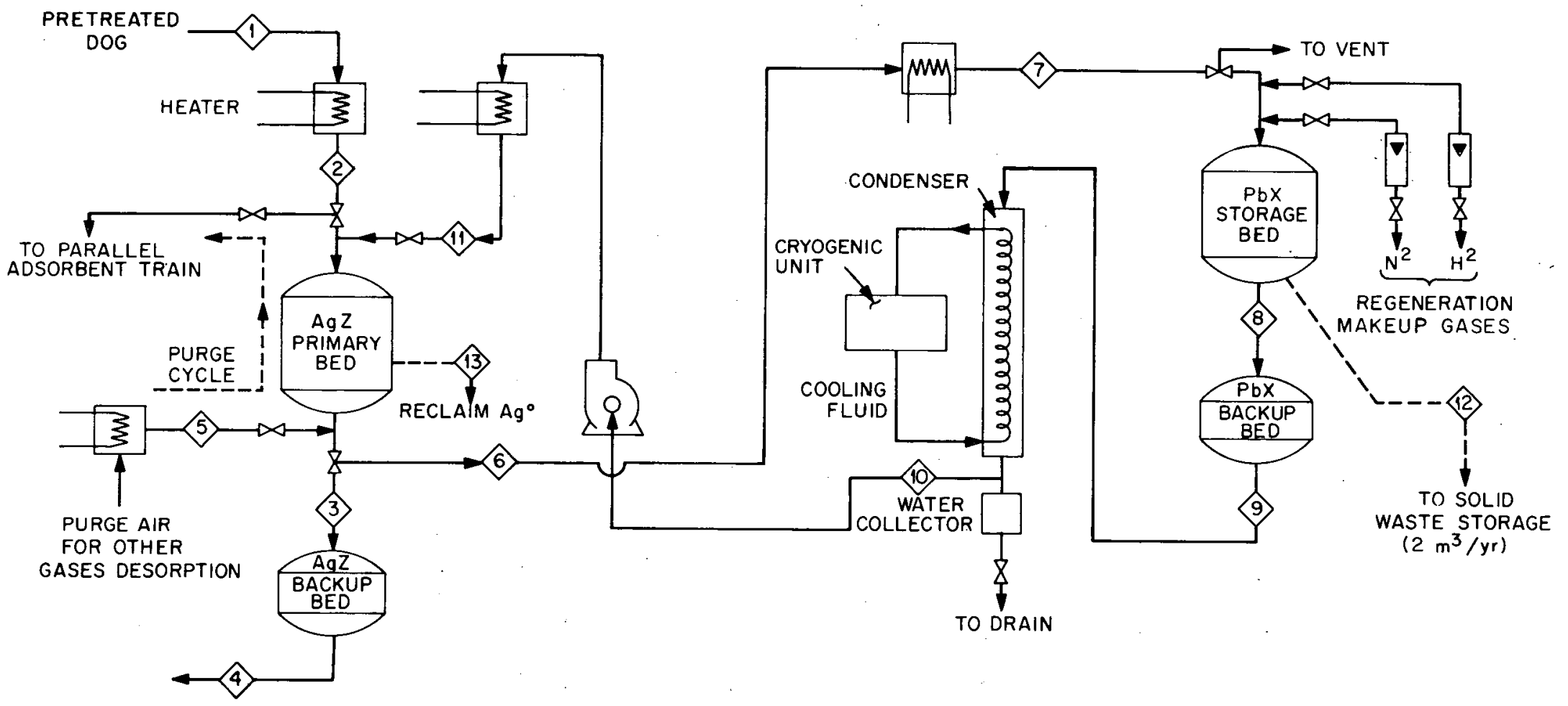

Fig. 5. Schematic of test equipment for sorption of iodine from dissolver off-gas using mordenite beds. 
1. The capability of multiple regeneration reduces the process cost. Silver-exchanged mordenites maintain loading capacity for many more cycles than do silverexchanged zeolites, AgX.

2. In general, $\mathrm{Ag}^{\circ} \mathrm{Z}$ materials are much more resistant than silver zeolites to the corrosive effects of $\mathrm{NO}_{\mathrm{x}}{ }^{\prime} \mathrm{s}$ in humid gas streams.

3. The presence of up to $2 \%$ NO in gas streams containing up to $6 \% \mathrm{H}_{2} \mathrm{O}$ has been shown to actually increase the loading capacity of $\mathrm{Ag}^{\circ} \mathrm{Z}$.

4. The location of $\mathrm{Ag}^{\circ} \mathrm{Z}$ prior to $\mathrm{NO}_{\mathrm{x}}$ scrubbing would allow direct treatment of DOG. The problem with iodine inventory in recovered head-end acid would be avoided.

5. Mordenites should be able to tolerate fluorides in the off-gas for thorium-based fuel cycles. However, this interaction is untested and it is possible that problems could be introduced by irreversible reaction between the sorbents and fluorides.

\subsubsection{Process disadvantages}

To optimize the application of the silver mordenite--lead mordenite system for iodine species removal from off-gases, consideration should be given to the following suggestions.

1. All of the studies with the silver mordenite--lead zeolite (or mordenite) tandem system have been conducted with only elemental iodine. To ensure 
the future applicability of this process, it is imperative that studies be conducted to determine the loading capacity (and removal efficiency or DF) of the process for organic iodides. Also, the possible poisoning effect of organic contaminants in dissolver off-gas should be studied.

2. The effect of a dew-point excursion on the continuous operation as related to uninterrupted loading and removal efficiency should be studied.

3. Further studies should be directed towards establishment of the total recycle life of the $\mathrm{Ag}^{\circ} \mathrm{Z}$ material.

4. Additional studies should be conducted to determine which lead-exchanged zeolite or mordenite is the proper choice for long-term storage of ${ }^{129} \mathrm{I}$.

5. Because the process would be much safer and simpler if the unreduced $\mathrm{AgZ}$ form could be used instead of $\mathrm{Ag}^{\circ} \mathrm{Z}$, the effects of $\mathrm{H}_{2} \mathrm{O}$, NO, and $\mathrm{NO}_{2}$ on the $\mathrm{DF}$ and loading capacity for $\mathrm{I}_{2}$ should be determined.

6. Because of obvious safety concerns, it is highly improbable that a pure hydrogen stream would be allowed in a fuel reprocessing plant. Further studies should be conducted to discover an alternative method for regeneration of the AgZ beds.

7. The DF, loading capacity, and iodine vapor pressure should be determined for $\mathrm{Pb}^{\circ} \mathrm{Z}$.

8. Most of the studies have been conducted in smal1-scale equipment. Additional tests should be conducted in engineering equipment. 


\subsection{Removal of Iodide Species from Gases by Utilizing Macroreticular Resins}

\subsubsection{Background}

Moore and Howerton 107 studied the application of macroreticular resins for removing molecular iodine and organic iodides from dry or moist air. These experiments were designed to assess the feasibility of using the resins to replace zeolites in off-gas iodine removal processes.

\subsubsection{Chemical mechanisms}

In general, the macroreticular resins attract molecules based on their relative hydrophobicity or hydrophilicity. Thus they are basically nonionic in their function and can be expected to show relatively strong attraction for uncharged molecules such as elemental iodine and organic iodide compounds, and relatively weak attractions for ionic iodide species. We could find no mechanistic studies conducted with these resins that would delineate the kinetics of their interaction with molecular iodine or organic iodides. In all cases, the macroreticular resins showed greater loading capacities for iodine species in air than in liquid streams. For more detail, see Sect. 4.3.2.

\subsubsection{Experimental results and engineering data useful for process design.}

Initial studies ${ }^{107}$ indicated that the resins of the Amberlite series XAD-2 through XAD-12 were capable of producing DFs of $10^{4}$ for removing $\mathrm{I}_{2}$ from dry air at a flow rate of $7.65 \mathrm{~m} / \mathrm{min}$ through a $0.5-\mathrm{cm}-\mathrm{ID}$ column, with an $\mathrm{I}_{2}$ feed concentration of $3 \times 10^{3} \mathrm{mg} / \mathrm{m}^{3}$. The operating conditions and experimental results obtained with representative members of the 
Amberlite series, limited to the three different types of matrix chemistry, are shown in Table $8^{108-110}$ In additional studies ${ }^{108}$ with XAD-12 for removing $\mathrm{I}_{2}$ from dry air, it was determined that the capacity and $\mathrm{DF}$ generally decreased as the temperature was increased to $100^{\circ} \mathrm{C}$. Also, the DF and loading capacity decreased as the relative humidity increased. Studies with other plastics such as polystyrene, polymethane, and polyethylene were not pursued because they showed too little capacity for the simplest case of removing $I_{2}$ from dry air.

In this same group of experiments, ${ }^{108} \mathrm{CH}_{3} \mathrm{I}$ was sorbed from dry air at $21^{\circ} \mathrm{C}$ on all of the following macroreticular resins: Bio Bead SM-1 and Bio Bead SM-2; Amberlite XAD-2, XAD-4, XAD-7, XAD-8, XAD-9, XAD-11, XAD-12, and XE-284. Methyl iodide loading was studied for flow rates of $7.65 \mathrm{~m} / \mathrm{min}$ of dry air containing 1 to $4 \times 10^{3} \mathrm{mg} \mathrm{CH}_{3} \mathrm{I}$ per $\mathrm{m}^{3}$. All of the polymers except XE-284 and XAD-12 sorbed less $\mathrm{CH}_{3} \mathrm{I}$ at elevated temperatures. Loading capacity of XAD-12 increased to a temperature of $50^{\circ} \mathrm{C}$ and then decreased as the temperature was increased. The only two sorbents that sorbed more than $10 \mathrm{mg} \mathrm{CH}_{3} \mathrm{I} / \mathrm{g}$ sorbent while delivering a $\mathrm{DF}>100$ were $\mathrm{XAD}-4$ and $\mathrm{XAD}-12$, but neither one could predictably maintain its $\mathrm{CH}_{3} \mathrm{I}$ sorption capacities above $100^{\circ} \mathrm{C}$.

A comparison has also been made of loading capacities and DFs that could be achieved for $\mathrm{I}_{2}$ and $\mathrm{CH}_{3} \mathrm{I}$ removal from dry air on $\mathrm{XAD}-12$, silver zeolite $(\mathrm{AgX})$, iodized charcoal, and the anion exchanger Dowex $1-\mathrm{X}^{110,111}$ (see ref. 110 in Table 8). Compared to charcoal and Amberlite XAD-12, the Dowex $1-\mathrm{X} 4$ and $\mathrm{AgX}$ beds had relatively low capacities for iodine. The DF for molecular iodine on AgX was as good as that obtained on any of the exchangers, with the iodized charcoal providing the largest loading 
Table 8. Sorption of iodine species from dry and humid air with macroreticular resins

\begin{tabular}{|c|c|c|c|c|c|c|c|c|}
\hline Ref. & Resin & $\begin{array}{l}\text { Bed } \\
\text { size } \\
(\mathrm{cm})\end{array}$ & $\begin{array}{c}\text { Feed } \\
\left(\text { per } \mathrm{m}^{3}\right)\end{array}$ & $\begin{array}{l}\text { Flow } \\
\text { rate } \\
(\mathrm{m} / \mathrm{min})\end{array}$ & $\begin{array}{l}\text { Loading } \\
\text { capacity }\end{array}$ & $\begin{array}{l}\text { Temp } \\
\left({ }^{\circ} \mathrm{C}\right)\end{array}$ & $\begin{array}{l}\text { Relative } \\
\text { humidity }\end{array}$ & DF \\
\hline \multirow[t]{3}{*}{107} & $\begin{array}{l}\text { Amberlite XAD- } 2^{b} \\
\text { (Styrene-DVB) } \\
20-50 \text { mesh }\end{array}$ & $\begin{array}{l}0.5 \times 10 \\
\left(\mathrm{~S}=0.916 \mathrm{~cm}^{2}\right)^{\mathrm{C}}\end{array}$ & $\begin{array}{l}3 \times 10^{3} \mathrm{mg} \mathrm{I} \mathrm{I}_{2} \\
(\sim 285 \mathrm{ppm})\end{array}$ & 7.65 & $172 \mathrm{mg} \mathrm{I} \mathrm{I}_{2} / \mathrm{g}$ & 221 & Dry air & $>10^{4}$ \\
\hline & $\begin{array}{l}\text { Amberlite XAD- } 4^{\mathrm{b}} \\
\text { (Styrene-DVB) }\end{array}$ & $0.5 \times 10$ & $3 \times 10^{3} \mathrm{mg} \mathrm{I} \mathrm{I}_{2}$ & 7.65 & $218 \mathrm{mg} \mathrm{I} / \mathrm{g}$ & $\sim 21$ & Dry air & $>10^{4}$ \\
\hline & $\begin{array}{l}\text { Amberlite XAD-12 }{ }^{\mathrm{b}} \\
\text { (Acrylic ester with } \\
\text { nitrogen-oxygen } \\
\text { group) }\end{array}$ & $0.5 \times 10$ & 3. $\times 10^{3} \mathrm{mg} \mathrm{I} 2$ & 7.65 & $209 \mathrm{mg} \mathrm{I}_{2} / \mathrm{g}$ & 221 & Dry air & $>10^{4}$ \\
\hline \multirow[t]{7}{*}{108} & Amberlite XAD-12 & $0.5 \times 10$ & $\begin{array}{l}2.8 \times 10^{3} \mathrm{mg} \mathrm{I} \mathrm{I}_{2} \\
(\mathrm{v} 266 \mathrm{ppm})\end{array}$ & $\mathrm{NS}^{\mathrm{d}}$ & $1390 \mathrm{mg} I_{2} / g$ & 21 & Dry air & $10^{2}-10^{3}$ \\
\hline & & $0.5 \times 10$ & $2.8 \times 10^{3} \mathrm{mg} \mathrm{I} 2$ & $\mathrm{NS}^{\mathrm{d}}$ & $990 \mathrm{mg} \mathrm{I} / \mathrm{g}$ & 50 & Dry air & $10^{3}-10^{4}$ \\
\hline & Amberlite XAD -4 & $0.5 \times 10$ & $\begin{array}{l}1-4 \times 10^{3} \mathrm{mg} \mathrm{CH}{ }_{3} \\
(170-680 \mathrm{ppm})\end{array}$ & 7.65 & $12 \mathrm{mg} \mathrm{CH}_{3} \mathrm{I} / \mathrm{g}$ & 25 & Dry air & $\sim 10^{2}$ \\
\hline & & $0.5 \times 10$ & $1-4 \times 10^{3} \mathrm{mg} \mathrm{CH}_{3} \mathrm{I}$ & 7.65 & $1.1 \mathrm{mg} \mathrm{CH} 3 \mathrm{I} / \mathrm{g}$ & 140 & Dry air & $1-2$ \\
\hline & Amberlite XAD-12 & $0.5 \times 10$ & $1-4 \times 10^{3} \mathrm{mg} \mathrm{CH}_{3} \mathrm{I}$ & 7.55 & $15 \mathrm{mg} \mathrm{CH}_{3} \mathrm{I} / \mathrm{g}$ & 25 & Dry air & $1.6 \times 10^{3}$ \\
\hline & & $0.5 \times 10$ & $1-4 \times 10^{3} \mathrm{mg} \mathrm{CH}_{3} \mathrm{I}$ & 7.65 & $84 \mathrm{mg} \mathrm{CH} \mathrm{CH}_{3} \mathrm{I} / \mathrm{g}$ & 50 & Dry air & $>10^{4}$ \\
\hline & & $0.5 \times 10$ & $1-4 \times 10^{3} \mathrm{mg} \mathrm{CH}_{3} \mathrm{I}$ & 7.65 & $10 \mathrm{mg} \mathrm{CH}_{3} \mathrm{I} / \mathrm{g}$ & 160 & Dry air & 16 \\
\hline
\end{tabular}


Table 8. (Continued)

\begin{tabular}{|c|c|c|c|c|c|c|c|c|}
\hline Ref. & Resin & $\begin{array}{l}\text { Bed } \\
\text { size } \\
(\mathrm{cm})\end{array}$ & $\begin{array}{c}\text { Feed } \\
\left(\text { per } \mathrm{m}^{3}\right)\end{array}$ & $\begin{array}{l}\text { Flow } \\
\text { rate } \\
(\mathrm{m} / \mathrm{min})\end{array}$ & $\begin{array}{l}\text { Loading } \\
\text { capacity }\end{array}$ & $\begin{array}{l}\text { Temp } \\
\left({ }^{\circ} \mathrm{C}\right)\end{array}$ & $\begin{array}{l}\text { Relative } \\
\text { humidity }\end{array}$ & DF \\
\hline \multirow[t]{3}{*}{109} & Amberlite XAD-4 & $\begin{array}{l}1 \times 5.08 \\
\left(\mathrm{~S}=0.785 \mathrm{~cm}^{2}\right)\end{array}$ & $\begin{array}{l}300-400 \mathrm{mg} \mathrm{I} \\
(28.5-38 \mathrm{ppm})\end{array}$ & 12.2 & $50 \mathrm{mg} \mathrm{I} \mathrm{I}_{2} / \mathrm{cm}^{3}$ sorbent & 25 & $60 \%$ & $3 \times 10^{3}$ \\
\hline & Amberlite XAD-12 & $1 \times 5.08$ & $300-400 \mathrm{mg} \mathrm{I} \mathrm{I}_{2}$ & 12.2 & $50 \mathrm{mg} \mathrm{I} \mathrm{I}_{2} / \mathrm{cm}^{3}$ sorbent & 25 & $60 \%$ & $7 \times 10^{3}$ \\
\hline & Silver zeolite & $1 \times 5.08$ & $300-400 \mathrm{mg} \mathrm{I} \mathrm{I}_{2}$ & 12.2 & $50 \mathrm{mg} \mathrm{I} \mathrm{I}_{2} / \mathrm{cm}^{3}$ sorbent & 25 & $60 \%$ & $7 \times 10^{3}$ \\
\hline \multirow{5}{*}{110} & Amberlite $\mathrm{XAD}-12^{\mathrm{e}}$ & $0.5 \times 5$ & 2 to $4 \times 10^{3} \mathrm{mg} \mathrm{I}_{2}$ & 7.65 & $1.39 \mathrm{~g} \mathrm{I}_{2} / \mathrm{g}$ & 25 & Dry air & 166 \\
\hline & Dowex $1-\mathrm{X} 4$ (OH form) & $0.5 \times 5$ & 2 to $4 \times 10^{3} \mathrm{mg} \mathrm{I}_{2}$ & 7.65 & $0.362 \mathrm{~g} \mathrm{I}_{2} / \mathrm{g}$ & 25 & Dry air & 20 \\
\hline & Silver zeolite & $0.5 \times 5$ & 2 to $4 \times 10^{3} \mathrm{mg} \mathrm{I} 2$ & 7.65 & $0.126 \mathrm{~g} \mathrm{I}_{2} / \mathrm{g}$ & 25 & Dry air & $1.2 \times 10^{3}$ \\
\hline & Iodized charcoal & $0.5 \times 5$ & 1 to $3 \times 10^{3} \mathrm{mg} \mathrm{CH}_{3} \mathrm{I}$ & 7.65 & $0.125 \mathrm{~g} \mathrm{CH}_{3} \mathrm{I} / \mathrm{g}$ & 25 & Dry air & ح 50 \\
\hline & Silver zeolite & $0.5 \times 5$ & 1 to $3 \times 10^{3} \mathrm{mg} \mathrm{CH}{ }_{3} \mathrm{I}$ & 7.65 & $0.150 \mathrm{~g} \mathrm{CH}_{3} \mathrm{I} / \mathrm{g}$ & 25 & Dry air & $3 \times 10^{3}$ \\
\hline
\end{tabular}

a Loading capacity is milligrams of iodine species per gram of sorbent of interest.

${ }^{b}$ Amberlite macroreticular resins are manufactured by Rohm \& Haas.

$\mathrm{C}_{\mathrm{S}}=$ column cross-sectional area.

dNS, not specified.

e Adding 24 wt \% n-dodecane to iodized charcoal caused a decrease in $I_{2}$ DF by a factor of 6 and a small decrease of $15 \%$ in $10 a d i n g$ capacity. Addition of 25 wt \% dodecane to XAD-12 resulted in an increase in 12 DF from 100 to 500 , but 1oading capacity was decreased by $42 \%$ 
capacity (2.13-g $I_{2} / g$ charcoal, and an $I_{2} D F$ of $2 \times 10^{3}$ ) of the four studied sorbents. Preloading the charcoal and XAD-12 with about 25\% of their weights as dodecane reduced the DF on the charcoal and the loading capacity of the XAD-12. The iodized charcoal sorbed 20 times more $\mathrm{I}_{2}$ than $\mathrm{CH}_{3} \mathrm{I}$, and the $\mathrm{DF}$ for $\mathrm{I}_{2}$ was 40 times that of $\mathrm{CH}_{3} \mathrm{I}$. Decontamination factors achieved with $\mathrm{AgX}$ for both $\mathrm{I}_{2}$ and $\mathrm{CH}_{3} \mathrm{I}$ removal from feed gases at $25^{\circ} \mathrm{C}$ and very low humidity agreed well with the results obtained by Ackley. 88

In a final limited study to determine the effect of humidity on the operation of the Amberlite resins, Moore ${ }^{109}$ investigated the sorption capacity of $\mathrm{XAD}-4$ and $\mathrm{XAD}-12$ for removal of $\mathrm{I}_{2}$ from air at $25^{\circ} \mathrm{C}$ and $60 \%$ relative humidity. The results were promising, with DFs greater than $10^{3}$ being obtained on $5.08-\mathrm{cm}$-deep beds for loadings to $50 \mathrm{mg} \mathrm{I} / \mathrm{cm}^{3}$ sorbent. The other Amberlite macroreticular resins (XAD-2, XAD-7, XAD-8, $X A D-9, X A D-11$ ) did not show promising DFs for $I_{2}$ in air-feed concentrations of 300 to $400 \mathrm{mg} \mathrm{I} \mathrm{I}_{2} / \mathrm{m}^{3}$ (28 to $38 \mathrm{ppm}$ ).

\subsubsection{Present application}

Utilization of macroreticular resins to remove iodine species from gas streams were of an experimental nature, as discussed above.

\subsubsection{Process capacity}

Maximum capacity of XAD-12 for molecular iodine removal from dry air at room temperature was $1.4-\mathrm{g} \mathrm{I}_{2} / g$ resin $\left(\mathrm{DF}, 10^{2}\right.$ to $10^{3}$ ), and for $\mathrm{CH}_{3}$ I. removal from dry air at $50^{\circ} \mathrm{C}$, the capacity was $84-\mathrm{mg} \mathrm{CH}_{3} \mathrm{I} / \mathrm{g}\left(\mathrm{DF}, 10^{4}\right)$. When dry air was the carrier, maximum capacities for XAD-4 were 218-mg 
$\mathrm{I}_{2} / \mathrm{g}\left(\mathrm{DF}>10^{4}\right)$ and $12.0-\mathrm{mg} \mathrm{CH}_{3} \mathrm{I} / \mathrm{g}$ resin $\left(\mathrm{DF}, 10^{2}\right)$. Feed concentrations of $\mathrm{I}_{2}$ and $\mathrm{CH}_{3} \mathrm{I}$ were in the range 200 to $700 \mathrm{ppm}$.

\subsubsection{Process advantages}

The studies to delineate the ability of macroreticular resins to remove $\mathrm{I}_{2}$ and $\mathrm{CH}_{3} \mathrm{I}$ were too limited to allow establishment of many process advantages. One obvious advantage is that macroreticular resins are acid resistant and thus they may function well in off-gases con-. taining $\mathrm{NO}_{\mathrm{x}}$.

\subsubsection{Process disadvantages}

1. The process.DF and loading capacity appear to be seriously affected by high temperature and high humidity.

2. Organics are strongly attracted to macroreticular resins; thus the presence of organics in fuel reprocessing off-gas could result in serious deterioration in loading capacity.

3. All of the studies thus far have been conducted in sma11scale equipment ( 0.5 to $1.0-\mathrm{cm}-\mathrm{ID}$ columns). Any additional studies should be made in engineering-sized equipment.

4. METHODS OF REMOVING IODINE SPECIES FROM FUEL REPROCESSING WASTE LIQUID STREAMS

\subsection{Background and Introduction}

A paramount consideration in minimizing the environmental impact of both nuclear fuel reprocessing plants and nuclear power generating facilities is the removal of radioactive iodine species from off-gases 
and waste liquid streams. The report by Finney et al., ${ }^{3}$ which includes a comprehensive discussion of the optimization of LWR fuel reprocessing, provides information needed to establish as-low-as-practicable emission limits for the various radionuclides encountered in reprocessing (see Fig. 6). A single case for a specific plant design will be used as the basis for providing working estimates of the amount of iodine that could be released into the environment for those processes following the iodine removal partial evaporator (IRPE). It is assumed that the off-gas will be treated to minimize effluent iodine and iodides.

Based on efficient iodine volatilization from the dissolver solution (possibly in combination with some form of voloxidation for the chopped fuel prior to dissolution), it is also assumed that $99.5 \%$ of the iodine (mostly ${ }^{129} I$ and ${ }^{131} I$ ) would enter the primary off-gas treatment system. Thus the maximum quantity of iodine that could enter the liquid rad-waste treatment system would be $0.5 \%$ of $\mathrm{F}_{\mathrm{I}}$ (moles of iodine into the plant per unit time). The three primary streams comprising the feed to the liquid treatment system, as input to the low-activity liquid-waste fractionator, would be the acid bottoms from the $\mathrm{NO}_{2}$ absorber, the condensate from the high-activity waste concentrator, and the raffinate from the solvent cleanup. If $0.5 \%$ of the iodine fed to the reprocessing plant became concentrated in the IRPE, about $0.025 \%$ of the total plant iodine could be discharged to the excess-water vaporizer. Since the yearly input of ${ }^{129}$ I to the standard plant discussed by Finney ${ }^{3}$ (1500 MTHM/year, fuel irradiated to $33,000 \mathrm{MWd} / \mathrm{ton}$ at $30 \mathrm{~kW} / \mathrm{kg}$, and cooled 160 days before reprocessing) would be approximately $286.5 \mathrm{~kg}(49.95 \mathrm{Ci}){ }^{129}$ I/year, the discharge to the environment from the liquid waste treatment loop 
MODEL FUEL REPROCESSING PLANT: CASE 2a-REDUCTION IN RELEASE OF IODINE

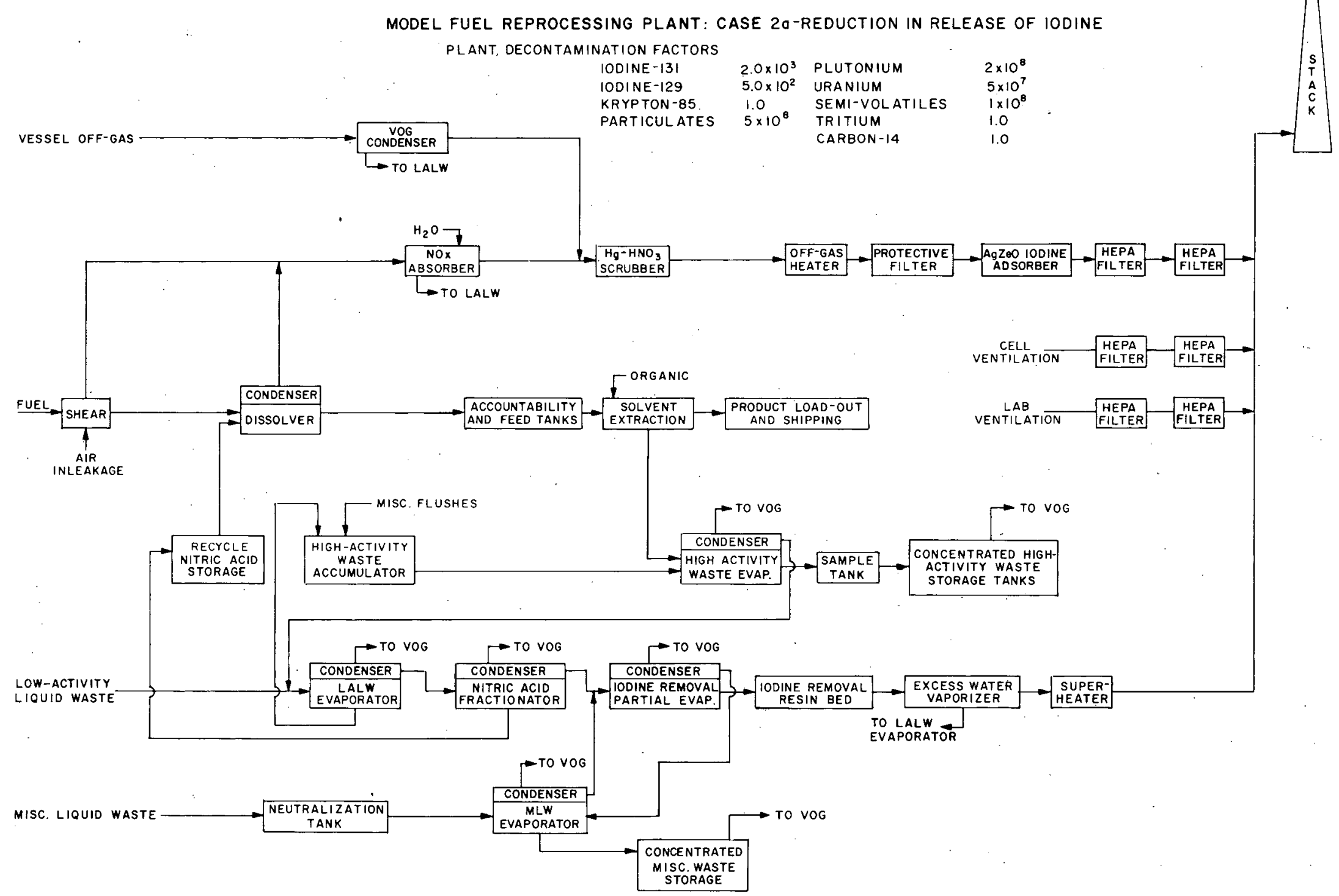

Fig. 6. Model fuel reprocessing plant: Case $2 a$ - reduction in release of iodine. 
could be as much as $1.3 \times 10^{-2} \mathrm{Ci} /$ year. For Finney's case $2 \mathrm{a}$, in which $99.5 \%$ of the iodine is volatilized, the iodine concentration in a reference $20-\mathrm{gpm}$ liquid discharge would be $0.85 \times 10^{-8} \mathrm{M}$ in ${ }^{129} \mathrm{I}_{2}$. The waste stream is expected to contain 0.05 to $0.10 \mathrm{M} \mathrm{HNO}_{3}$. If all the $\mathrm{I}_{2}$ were discharged to the stock in $3000 \mathrm{scfm}$, the $\mathrm{I}_{2}$ level would be $0.18-\mathrm{ppb}{ }^{129} \mathrm{I}_{2}$, or $1.95-\mu \mathrm{g}{ }^{129} \mathrm{I}_{2} / \mathrm{m}^{3}$. This analysis delineates the concentrations of iodine that should be included in simulated gas and liquid streams used in experiments to develop methods of obtaining zero release in the liquid radwaste treatment loop.

\subsection{Removal of Iodine Species from Liquid Streams Utilizing Activated Charcoal}

\subsubsection{Background}

Few reports are available concerning the application of charcoal for removal of iodine species from waste liquors. One of the rapidly growing industrial applications of activated charcoal is for the secondary and tertiary treatment of industrial and municipal sewages. This utilization is primarily focused on removal of hazardous organics, whereas only limited industrial effort has been directed towards the metal-removing capacity of charcoal.

\subsubsection{Chemical species of dissolved iodine}

A major consideration in the choice of a sorbent to treat liquid streams containing iodine is the chemical form of the iodine in the liquid of interest. For example, Eggleton ${ }^{112}$ listed eight equilibria for the partitioning of iodine between water and air [where all species are in the aqueous phase except those specifically designated as gas phase species, that is, $I_{2}(g)$ and $\left.\operatorname{HOI}(g)\right]$ : 


$$
\begin{array}{ll}
\mathrm{I}_{2}(\mathrm{~g})=\mathrm{I}_{2} & \mathrm{~K}_{1}=83 \\
\mathrm{I}_{2}+\mathrm{I}^{-}=\mathrm{I}_{3}^{-} & \mathrm{K}_{2}=768 \\
\mathrm{I}_{2}+\mathrm{H}_{2} \mathrm{O}=\mathrm{H}^{+}+\mathrm{I}^{-}+\mathrm{HIO} & \mathrm{K}_{3}=5.4 \times 10^{-13} \\
\mathrm{I}_{2}+\mathrm{H}_{2} \mathrm{O}=\mathrm{H}_{2} \mathrm{OI}^{+}+\mathrm{I}^{-} & \mathrm{K}_{4}=1.2 \times 10^{-11} \\
3 \mathrm{I}_{2}+3 \mathrm{H}_{2} \mathrm{O}=\mathrm{IO}_{3}^{-}+5 \mathrm{I}^{-}+6 \mathrm{H}^{+} & \mathrm{K}_{5}=4 \times 10^{-48} \\
\mathrm{HIO}^{+} \mathrm{H}^{+}+\mathrm{IO}^{-} & \mathrm{K}_{6}=2.3 \times 10^{-4} \\
\mathrm{IO}^{-}+\mathrm{I}^{-}+\mathrm{H}_{2} \mathrm{O}=\mathrm{I}_{2} \mathrm{OH}^{-}+\mathrm{OH}^{-} & \mathrm{K}_{7}=0.13 \\
\mathrm{HIO}(\mathrm{g})=\mathrm{HIO} & \mathrm{K}_{8}=10^{2} \text { to } 10^{5}
\end{array}
$$

The concentration of the anionic species of iodine such as $\mathrm{I}^{-}$and $\mathrm{I}_{3}{ }^{-}$would thus appear to be quite low for neutral solutions in normal circumstances. However, it is known ${ }^{113}$ that the stability of elemental iodine $\left(I_{2}\right)$ is greatly decreased at low concentrations because elemental iodine is both a better oxidizing and a better reducing agent when the concentration of elemental iodine is low. That is, in an aqueous solution at $\mathrm{pH} 7$, for a total iodine concentration of $10^{-3} \mathrm{M}$, elemental iodine is $8 \%$ hydrolyzed; however, at a concentration of $10^{-8} \underline{\mathrm{M}}$, elemental iodine is almost totally hydrolyzed (98\%). At low concentrations of iodine, HIO is only slightly unstable in respect to decomposition into elemental iodine and $\mathrm{IO}_{3}{ }^{-}$, and any production of ionic iodine from HIO decomposition should be minimal. Eggleton ${ }^{112}$ also suggested that the equilibrium of iodine species in iodine-containing acidic solutions at values of $\mathrm{pH}$ down to 1 could be described by Eqs. (31)-(34).

Davis and Kibbey ${ }^{114}$ investigated the various species of iodine in acidic, neutral, and basic solutions (ranging from $3 \underline{\mathrm{M}} \mathrm{HNO}_{3}$ to $1 \underline{\mathrm{M}} \mathrm{NaOH}$ ) for wavelengths from 190 to $700 \mathrm{~nm}$. Utilizing a model for spectra 
analyses based on approximation by a series of overlapping bands of Gaussian shape, they reported iodine species for the various solutions listed in Table 9. The results shown in Table 9 are discussed here to provide background information concerning the kinds of iodine species that can be expected as a function of the $\mathrm{pH}$ of nitric acid solutions during dissolution of spent fuel or for other solvents used to extract or dissolve iodine.

Table 9. Most probable forms of iodine present in the acidic, neutral, and basic solutions of the indicated composition and concentrationa

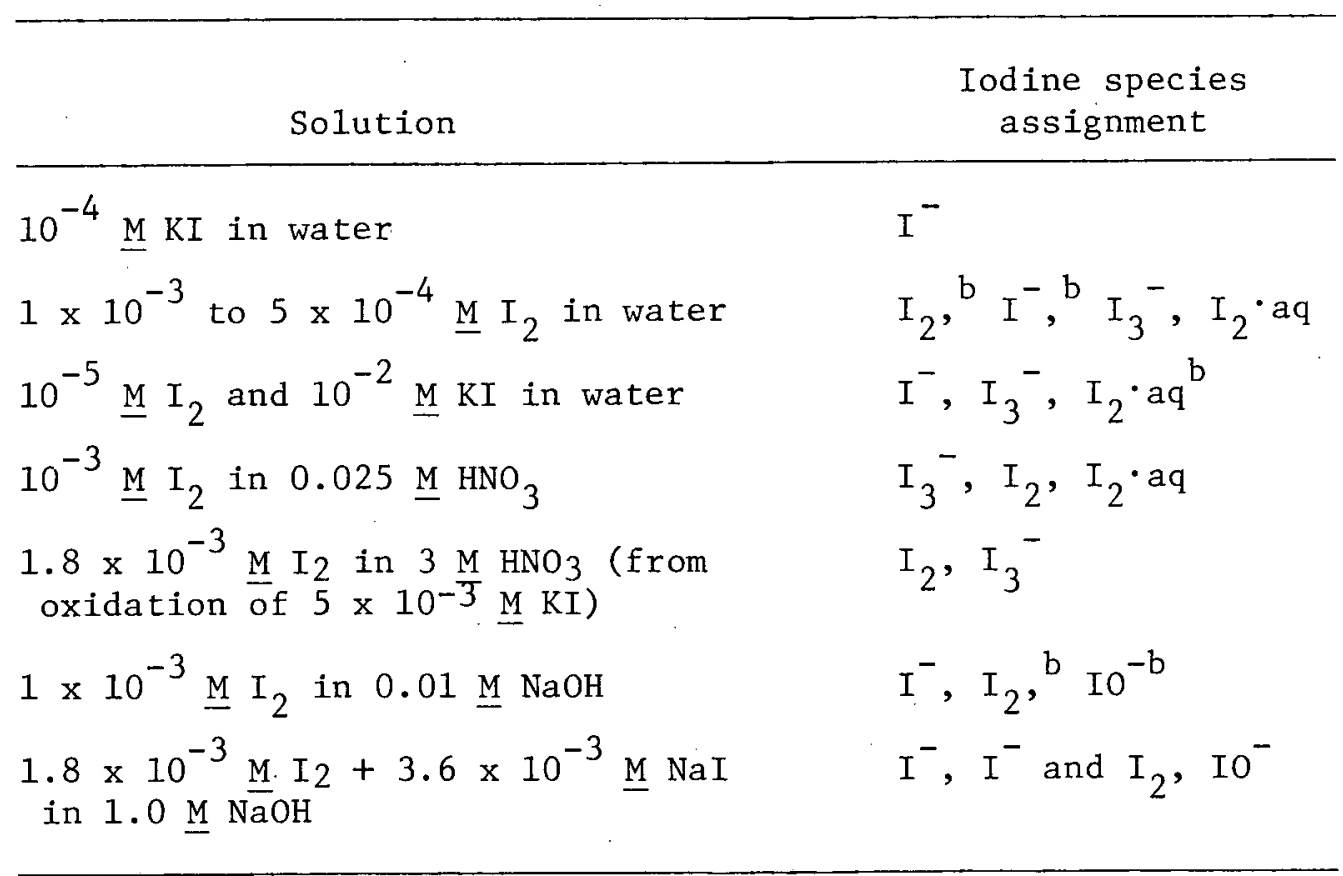

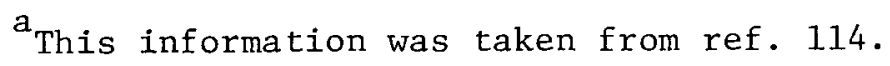

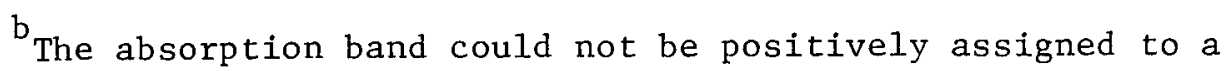
molecular species. 
Although further references will be made to Table 9 in the following discussions of the use of various solid sorbents for removing iodine species from liquid streams, a few introductory comments are appropriate. It should be noted that: (1) virtually all of the iodine was considered to exist as $\mathrm{I}^{-}$in a $10^{-4}$ M iodide solution in $\mathrm{H}_{2} \mathrm{O}$; (2) small quantities of ionic iodine species, probably as $\mathrm{I}^{-}$and $\mathrm{I}_{3}{ }^{-}$, were in a $10^{-4} \underline{\mathrm{M}}$ elemental iodine $\left(\mathrm{I}_{2}\right)$ solution in water; (3) for $10^{-3} \underline{\mathrm{M}} \mathrm{I}_{2}$ in mildly acidic solutions of $0.025 \mathrm{M}_{3} \mathrm{HNO}_{3}$, there was again an ionic form of iodine (probably $\mathrm{I}_{3}{ }^{-}$), in addition to elemental iodine and $\mathrm{I}_{2} \cdot \mathrm{aq}$; (4) when $10^{-3} \mathrm{M} \mathrm{I}^{-}$was dissolved in $3.0 \mathrm{M} \mathrm{HNO}_{3}$, essentially all of the $\mathrm{I}^{-}$, was oxidized to elemental iodine in about 4 to $5 \mathrm{hr}$ (for intermediate times, most of the $\mathrm{I}^{-}$was converted to $\mathrm{I}_{3}{ }^{-}$prior to oxidation to $\mathrm{I}_{2}$ ); and (5) elemental iodine dissolved in $\mathrm{NaOH}$ was slowly reduced to $\mathrm{I}^{-}$ and $\mathrm{IO}^{-}$.

\subsubsection{Experimental results and engineering data useful for process design} Activated charcoal has been used to treat gas and liquid waste streams for many years in process industries, so that much of the present applicable charcoal technology has developed from the industrial sector. The utilization of granular activated charcoal for wastewater treatment has been given impetus by the development of economical carbon regeneration methods with ancillary transporting and processing equipment. Basically, granular activated charcoal is used either for tertiary treatment of liquid wastes following primary settling and secondary biological treatment, or for physical-chemical treatment in which raw wastewater is treated in a primary clarifier with chemicals prior to carbon adsorption. 115 
Lehmann ${ }^{116}$ has compiled a list of 190 selected references which describe the use of activated charcoal to treat wastewaters (both at laboratory and plant scale), and for uses such as air pollution control, gas and water analysis, and adsorption of radioisotopes (no iodine studies).

Although activated charcoal is widely utilized to sorb organic compounds from aqueous solutions, it is only recently that an effort has been made to develop industrial processes to use charcoal for sorption of inorganic compounds from waste liquors. Sigworth ${ }^{117}$ reviewed the literature of the metallurgical industries and discussed the applicability of activated charcoal for sorption of $\mathrm{Sb}, \mathrm{Ag}, \mathrm{Bi}, \mathrm{Cr}, \mathrm{Sn}, \mathrm{Ag}, \mathrm{Hg}, \mathrm{Co}, \mathrm{Zr}$, $\mathrm{Pb}, \mathrm{Ni}, \mathrm{Ti}, \mathrm{V}, \mathrm{Fe}$ (all having fair to high adsorption potentials) and $\mathrm{Cu}$, $\mathrm{Cd}, \mathrm{Zn}, \mathrm{Be}, \mathrm{Ba}$, Se, Mo, Mn, and $\mathrm{W}$ (all having low or unknown adsorption potentials). It was noted that of the halogens, chlorine and bromine were adsorbed well from water and reduced on the charcoal. When chlorine molecules accumulate on the carbon surface, a concentration can be reached at which a reaction between chlorine, water, and carbon produces $\mathrm{HCl}$ and $\mathrm{CO}_{2}$. Bromine is more strongly adsorbed than is chlorine, with similar conversion to hydrobromic acid. When activated carbon is used as the sorbent, fluoride ion can be removed from $\mathrm{H}_{2} \mathrm{O}$ at a $\mathrm{pH}$ of 3.0 . Activated charcoal was reported to adsorb iodine very strongly when it was in the free-elemental $\mathrm{I}_{2}$ or triiodide $\left(\mathrm{I}_{3}{ }^{-}\right)$state. Thus the sorption of free iodine would seem to be favored for high-elemental iodine concentrations (in the aqueous phase), and sorption of iodine as $\mathrm{I}_{3}{ }^{-}$would seem to be favored for very low concentrations of $\mathrm{I}_{2}$ in aqueous solution (see Sect. 4.2.2 and ref. 113). When the elemental iodine was sorbed to the charcoal, it was not reduced to $\mathrm{HI}$ (although $\mathrm{Cl}_{2}$ and $\mathrm{Br}_{2}$ are normally converted to $\mathrm{HCl}$ and $\mathrm{HBr}$ ). As a confirmation of the observed 
affinity of charcoal for iodine primarily as elemental iodine $\left(\mathrm{I}_{2}\right)$ or $\mathrm{I}_{3}{ }^{-}$, it was noted that iodides were sorbed to a lesser degree to charcoal. The iodine could be recovered fairly easily as elemental $I_{2}$ from its complex with charcoal.

The interaction between charcoal and elemental iodine was once exploited on a commercial scale for the recovery of iodine from oil brines in California. ${ }^{118}$ The General Salt Company utilized charcoal to remove iodine from brines that had first been acidified and oxidized to ensure that iodine, was in the elemental $I_{2}$. form. The iodine was then extracted from the charcoal with caustic soda or caustic potash. Concentration of iodine in the brines was usually in the 10 to 100 -ppm range.

One of the earliest studies concerning the removal of radioactive iodine from water was conducted by Graham et al. ${ }^{119}$ In an investigation to develop methods for purifying surface water for human consumption in the event of radioactive contamination from nuclear weapons testing or from nuclear waste disposal, a solution containing only ${ }^{131}$ I as elemental iodine was sorbed with a commercial dechlorinator that contained activated charcoal. The feed solution contained $25 \mu \mathrm{Ci}$ of ${ }^{131}$ I/liter, which, for a specific activity of $1.24 \times 10^{5} \mathrm{Ci} / \mathrm{g}{ }^{131} \mathrm{I}$, resulted in an ${ }^{131} \mathrm{I}$ concentration of only $7.7 \times 10^{-13}$ M. Even at this very low feed concentration, DFs of $10^{3}$ were obtained. The loading capacity was not determined.

Westvaco ${ }^{120}$ uses the capacity of their charcoal for iodine as an analytical technique to specify relative activities of charcoals prepared by different processes. 
In agreement with Sigworth's ${ }^{117}$ observations, Kreusch ${ }^{121}$ has recently reported that iodine is reversibly sorbed to activated carbon in the presence of organics. That is, elemental iodine was sorbed to charcoal to act as a bacteriostatic agent during treatment of water contaminated with bacterial growth. Iodine was applied to the charcoal bed in a 0.1 to $0.2 \underline{\mathrm{N}}$ solution at a rate of 0.03 to $0.167 \mathrm{~cm}^{3} / \mathrm{min}$ (per $\mathrm{m}^{3}$ of charcoal). When the elemental iodine interacted with the organics in the feed stream, free active $\mathrm{I}^{-}$was apparently produced and eluted from the bed. The nature of the interaction between elemental iodine and the organic compounds was not elucidated.

Bansal et a1. ${ }^{122}$ studied the adsorption characteristics of carbon obtained from polyvinyl chloride (PVC). The PVC-derived charcoal had a greater affinity for removing iodine from chloroform in equilibrium shakeouts at $25^{\circ} \mathrm{C}$ than from water or benzene. The elemental iodine was bound to the charcoal from all three of the solutions by an almost equivalent combination of physical adsorption and chemisorption (slightly more $\mathrm{I}_{2}$ was chemisorbed than physisorbed for all three solvents). For iodine removal from aqueous solution onto charcoal, the maximum amount physically adsorbed was $50-\mathrm{mg} \mathrm{I}_{2} / \mathrm{g}$, and the amount chemisorbed was $77-\mathrm{mg}$ $\mathrm{I}_{2} / \mathrm{g}$. When iodine was sorbed from chloroform on the PVC carbon, the amounts increased to $228-\mathrm{mg} \mathrm{I}_{2} / \mathrm{g}$ for physical adsorption and 203-mg $\mathrm{I}_{2} / \mathrm{g}$ for chemisorption. It was concluded that sorption of iodine by PVCderived carbon was maximum with chloroform as the solvent because of a much lower solute-solvent interaction than either in water (due to the presence of iodide ion) or in benzene (in which iodine is much more soluble). The increase in iodine sorption by the PVC carbon from organic 
solvents appears to be contradictory to Kreusch's observation, and the generally held conclusion that charcoal would have a greater affinity for organics than for iodine; in other words, less iodine would be sorbed in the presence of organics. However, the activated chemical structure of the PVC carbon may be different than that of ordinary wood-derived or coconut-based charcoals. Also, the sorptive capacity of iodine in the organic solvents must be considered.

Further evidence concerning the relative attraction of elemental iodine and iodide to activated carbon was given by Belogovskii. ${ }^{123}$ To maximize regeneration of the carbon, samples of $\mathrm{KAD}$-iodine-activated carbon, which had been loaded to a capacity of $37.5 \mathrm{~g}$ of iodine per liter of solid material, were treated with sodium hydroxide in an ultrasonic field. Based on a density of $0.3 \mathrm{~g}$ of charcoal per $\mathrm{ml}$, this is a loading capacity of $\sim 100 \mathrm{mg}$ per $\mathrm{g}$ of charcoal. The effect of the ultrasound probably was to promote contact between the $\mathrm{NaOH}$ and the iodineladen charcoal so that adsorbed $I_{2}$ was converted from the elemental to the ionic form which had much less attraction to the activated charcoal and could be more easily eluted by caustic alkali.

Activated carbon has been utilized industrially in the Soviet Union for the production of iodine from oil well byproduct brines. A supportive study $^{124}$ investigated the partial pressure of iodine over aqueous salt solutions. Usually the brines are alkaline because of the presence of bicarbonates and salts of naphthenic acids. However, to prevent hydrolysis of iodine during the recovery process and to oxidize all iodine to the $\mathrm{I}_{2}$ form, the brines are acidified with sulfuric acid to a $\mathrm{pH}$ of about 3.0 $\left(0.0005 \mathrm{M} \mathrm{H}_{2} \mathrm{SO}_{4}\right)$. The following conclusions were made concerning the 
distribution of iodine between air and the sulfate salts of sodium, potassium, and magnesium, and air and the chloride salts of sodium, . potassium, magnesium, and calcium: (1) for a range of iodine concentrations of 10 to $272 \mathrm{mg} /$ liter, the iodine partial pressure and distribution coefficient for the brines obeyed Henry's law (for acidification to pH $3.0)$; (2) for the temperature range 0 to $50^{\circ} \mathrm{C}$, chlorides reduced the iodine partial pressure and distribution coefficient, but sulfates had the opposite effect.

In their program to investigate the capability of various solid sorbents to remove elemental iodine from liquid streams, Moore and Howerton ${ }^{125}$ conducted limited experiments with activated charcoal. Elemental iodine at a concentration of $1 \times 10^{-6} \underline{\mathrm{M}} \mathrm{I}_{2}$ (traces of ${ }^{131} \mathrm{I}$ ) in water was sorbed with 20 to 50 mesh, Fisher-activated coconut charcoal in a $0.4 \times 10-\mathrm{cm}$ column. DFs of $10^{4}$ were obtained for flow rates as high as $15 \mathrm{~cm} / \mathrm{min}$, but loading capacities were not determined. A summary of the various experiments using charcoal to treat liquid streams for iodine removal is given in Table 10.

The quantity of iodine removed from gas streams by activated charcoal is apparently dependent on the metal content (primarily as $\mathrm{K}^{+}$) of the charcoal (Sect. 3.1.2). ${ }^{46}$ It thus follows that to remove iodine from liquids in which the iodine is in both elemental and ionic forms, the capacity of activated charcoal for total iodine would be enhanced by the binding capacity that the metal in the structure has for ionic iodine species. The increase in capacity for ionic iodine that results from the presence of metals may account for the high DFs that were obtained 125 
Table 10. Removal of iodine species from liquid wastes by treatment with activated charcoal

\begin{tabular}{|c|c|c|c|c|c|c|c|}
\hline Ref. & $\begin{array}{l}\text { Charcoal } \\
\text { form }\end{array}$ & $\begin{array}{c}\text { Feed } \\
\text { composition }\end{array}$ & $\mathrm{DF}^{\mathrm{a}}$ & $\begin{array}{c}\text { Distribution } \\
\text { ratio }\end{array}$ & $\begin{array}{l}\text { Bed } \\
\text { size }\end{array}$ & $\begin{array}{l}\text { Retention } \\
\text { time }^{a}\end{array}$ & $\begin{array}{l}\text { Loading }_{a} \\
\text { capacity }\end{array}$ \\
\hline 117 & Activated & Aqueous & Good & $\dot{\mathrm{NA}}$ & NS & ND & ND \\
\hline 119 & Activated & $\begin{array}{l}25-\mu \mathrm{Ci}{ }^{131} \mathrm{I} / \text { iter or } \\
7.7 \times 10^{-13} \mathrm{M}{ }^{13 \mathrm{I}_{2}} \\
\text { aqueous }\end{array}$ & $10^{3}$ & NA & NS & $\mathrm{ND}$ & ND \\
\hline \multirow[t]{2}{*}{122} & $\begin{array}{l}\text { From polyvinyl } \\
\text { chloride }\end{array}$ & Iodine in $\mathrm{H}_{2} \mathrm{O}$ & ND & ND & NA & $\begin{array}{l}\text { Batch } \\
\text { equilibrium }\end{array}$ & $\begin{array}{l}77-\mathrm{mg} \mathrm{I}_{2} / \mathrm{g}^{\mathrm{b}} \\
\text { of charcoal }\end{array}$ \\
\hline & $\begin{array}{l}\text { From polyvinyl } \\
\text { chloride }\end{array}$ & Iodine in chloroform & ND & ND & NA & $\begin{array}{c}\text { Batch } \\
\text { equilibrium }\end{array}$ & $\begin{array}{l}205-\mathrm{mg} \mathrm{I}_{2} / \mathrm{g} \\
\text { of charcoal }\end{array}$ \\
\hline 123 & Activated & $\mathrm{ND}^{\mathrm{C}}$ & ND & NA & NS & NA & $\begin{array}{l}\mathrm{w}_{100-\mathrm{mg} \mathrm{I}} / \mathrm{g} \\
\text { of charcoal }\end{array}$ \\
\hline 125 & $\begin{array}{l}\text { Fisher activated } \\
\text { coconut base } \\
\text { charcoal }\end{array}$ & $\begin{array}{l}1 \times 10^{-6} \mathrm{M} \mathrm{I}_{2}^{-} \text {in } \\
\text { aqueous }\end{array}$ & $10^{4}$ & NA & $0.4 \times 10 \mathrm{~cm}$ & $1.0 \mathrm{~min}$ & - ND \\
\hline
\end{tabular}

- not applicable; ND - not determined; NS - not specified.

${ }^{b}$ Represents quantity. chemisorbed. Approximately the same quantity was also physically adsorbed.

Desorption by ultrasound and $\mathrm{NaOH}$ of charcoal preloaded with iodine. 
when iodine was removed from a $10^{-6} \underline{\mathrm{M} \mathrm{I}} 2$ aqueous solution in which iodine was present primarily as elemental iodine $\left(\mathrm{I}_{2}\right)$, but also existed as traces of $\mathrm{I}^{-}$and $\mathrm{I}_{3}^{-}$.

\subsubsection{Present applications}

No references were encountered which described a functioning industrial operation in the United States in which activated charcoal was used for the specific recovery of iodine. However, from 1929 to 1934, the General Salt Company at Long Beach, California used activated charcoal to extract iodine from oil field brines on a commercial scale. This process was abandoned due to the inability to recover an iodine product that was economically competitive with the iodine produced from Chilean saltpeter. Dow Chemical Co. at Soul Beach, California has recovered iodine from oil field brines by a process involving flocculation with $\mathrm{FeCl}_{3}$, acidification with $\mathrm{H}_{2} \mathrm{SO}_{4}$, blowing-out of iodine from the oxidized brine using air, absorption of blown-out iodine with an aqueous solution of HI and $\mathrm{H}_{2} \mathrm{SO}_{4}$ in a packed tower, reduction of elemental iodine to $\mathrm{HI}$ with $\mathrm{SO}_{2}$ and $\mathrm{H}_{2} \mathrm{O}$, and recovery of $\mathrm{I}_{2}$ from the $\mathrm{HI}$ and $\mathrm{H}_{2} \mathrm{SO}_{4}$ solution by sparging with $\mathrm{Cl}_{2}$

\subsubsection{Process capacity}

Based on other studies, 122,123 activated carbon would appear to have an iodine loading capacity in aqueous solutions of about 100-mg $\mathrm{I}_{2} / \mathrm{g}$ carbon. However, there is such a paucity of established data concerning the iodine capacity of charcoal in acidic, neutral, and basic aqueous liquors that obviously much additional parametric work is needed on that subject. 


\subsubsection{Process advantages}

Activated charcoal appears to be comparable to any medium used to remove iodine from very low concentrations in aqueous streams. We have cited examples of DFs of $>10^{3}$ being achieved for charcoal in treating iodine concentrations as low as $10^{-13}$ M.

\subsubsection{Process disadvantages}

Although some of the following statements may not be disadvantages for using charcoal as a sorbent of iodine from aqueous streams, the lack of experimental studies of that removal process have left many parametric relationships still to be determined.

1. When activated charcoal is used, most organics will generally displace elemental iodine, so that poisoning or competitive loading of charcoal beds by contaminant organics during removal of iodine from waste liquors must be considered probable. However, sorption of iodine that is dissolved in an organic solvent may be enhanced by low solutesolvent interaction.

2. The effect of a high concentration of iodine on removal efficiency and loading capacity of charcoal is not known.

3. The capacity of charcoal for iodine in elemental and ionic form should be determined. As part of that determination, the capacity for the different chemical species of iodine should be determined as a function of the $\mathrm{K}^{+}$(or other metal content) of impregnated charcoals. 
4. The effect of elevated temperature on. the removal efficiency and loading capacity of charcoal is unknown. However, the highest temperatures that would be reached in aqueous streams during fuel reprocessing would not likely pose the danger of charcoal ignition that has been observed for charcoal bed filtration of iodine from radioactive and thermally elevated off-gases.

5. However, studies would still be required to determine the suitability for disposal and methods of disposal of charcoal beds at the end of their effective filtering life.

6. The loading capacity and removal efficiency (i.e., DF) of charcoal to separate $\mathrm{CH}_{3} \mathrm{I}$ and other organic iodides from aqueous streams has not been established.

7. Most of the studies in which charcoal was used to remove iodine from liquids have been either batch distribution or small-column experiments. Additional studies should be conducted in larger-scale engineering equipment.

\subsection{Removal of Iodine Species from Liquid Streams by Utilizing Macroreticular Resins}

\subsubsection{Background}

Most of the studies involving removal of iodine species from aqueous streams with macroreticular sorbents that were used in this literature survey were conducted at Oak Ridge National Laboratory (ORNL) or Battelle Northwest Laboratory (BNWL). These resins were initially attractive because of good flow properties, stability in highly acidic 
solutions, and good sorption capacity for iodine. Exploratory studies showed that both bromine and iodine could be sorbed from a gas stream with dry or wet anion exchangers. ${ }^{126}$ Subsequent studies ${ }^{127,128}$ had indicated that anion exchange resins could be used to sorb elemental iodine from air and aqueous solutions. Initial bench-scale studies ${ }^{129}$ showed that elemental iodine could be sorbed from nitric acid solutions not only with macroreticular resins but also with polyethylene, PVC, polystyrene, and polyurethane foam. However, the plastic-based materials were not readily available commercially in a physical form that was amenable to process operations such as in a packed bed. Because of the commercial availability and favorable physical properties of macroreticular resins, they were chosen as the material with which to pursue parametric studies of elemental iodine $\left(\mathrm{I}_{2}\right)$ and $\mathrm{CH}_{3} \mathrm{I}$ sorption from neutral and acidic aqueous solutions.

\subsubsection{Physical properties}

The Amberlite resins $\mathrm{XAD}-2$ and $\mathrm{XAD}-4$ consist of beads that are agglomerations of many very small microspheres. The individual beads have an open-cell structure around the microspheres, which results in both a continuous gel phase and a continuous pore phase. The backbone of the microspheres is a polystyrene structure that exerts a strong attraction for removing hydrophobic organics from polar solvents. Following are examples of the physical properties of the macroreticular resin $\mathrm{XAD}-4:$ stable at temperatures to $250^{\circ} \mathrm{C}$; average bead diam, 0.35 to $0.45 \mathrm{~mm}$; wet density, $1.02 \mathrm{~g} / \mathrm{cm}^{3}$; surface area of the dried resin, 750 $\mathrm{m}^{2} / \mathrm{g}$; average pore diameter of dried resin, $50 \AA$. 
Considerable care must be exercised to prevent introduction of air into the hydrated resins, and extensive backwash and regeneration procedures are necessary when the macroreticular resins are recycled in situ in packed beds. It is generally desirable to load and elute the beds in ascending flow to maintain homogeneous sorbate loading zones.

\subsubsection{Experimental results and engineering data useful for process design}

Initial studies ${ }^{129}$ showed that when the macroreticular resin Bio-Bead SM-2 was used in a smal1 packed bed, a DF of 100 was produced for removing iodine from a $1.0 \mathrm{M} \mathrm{HNO}_{3}$ solution containing $1.1 \times 10^{-3} \mathrm{~N} \mathrm{I}_{2}$ (Table 11). Because of the low iodine loading capacity of the Bio-Bead SM-2 material (about 24-mg $I_{2} / g$ ), further studies were conducted with the AmberliteXAD series.

In equilibrium batch tests, ${ }^{130}$ the distribution coefficients were determined for elemental iodine distributing between neutral and nitric acid solutions and a series of macroreticular resins. The resins tested and their primary plastic composition are listed in Table 12. Testing conditions included variation in acid concentration of 0 to $7 \underline{M}$ with an initial elemental iodine concentration of $5 \times 10^{-5} \underline{\mathrm{M}}$. The XAD-12 resin had by far the greatest removal efficiency for separating iodine from water; however, it showed an unpromising affinity for iodine in nitric acid solutions. The $\mathrm{XAD}-2$ and $\mathrm{XAD}-4$ resins showed the highest affinity for iodine in acidic solutions, with a surprisingly small variation in removal efficiency when the acid concentration was increased from 0.1 to $7.0 \mathrm{M}$. Experimental conditions and distribution ratios of iodine between the representative resins, $\mathrm{H}_{2} \mathrm{O}$, and $0.1 \underline{\mathrm{M}} \mathrm{HNO}_{3}$ are 
Table 11. Sorption of iodine species from aqueous and acidic solutions with macroreticular resins at $21^{\circ} \mathrm{C}$

\begin{tabular}{|c|c|c|c|c|c|c|c|}
\hline Ref. & Kesin & $\begin{array}{l}\text { Bed } \\
\text { si ze }\end{array}$ & $\begin{array}{c}\text { Retention } \\
\text { time }\end{array}$ & $\begin{array}{l}\text { Loading } \\
\text { capacity }\end{array}$ & Feed & $\begin{array}{c}\mathrm{DF} \text { or } \\
\mathrm{DR}^{\mathrm{b}}\end{array}$ & $\begin{array}{l}\text { Flow } \\
\text { rate } \\
(\mathrm{m} / \mathrm{min})\end{array}$ \\
\hline 129 & $\begin{array}{l}\text { Bio-Bead SM-2, } \\
\text { nonion it: cross- } \\
\text { linked polystyrenc. } \\
\text { bead, -20+50) mesh }\end{array}$ & $\begin{array}{l}0.4 \mathrm{~cm} \times 10 \mathrm{~cm} \\
\left(\mathrm{~s}=0.125\left(\mathrm{~cm}^{2}\right)^{c}\right.\end{array}$ & $' 1,4$ min & $\begin{array}{l}24-\mathrm{mg} \mathrm{I}_{2} \\
\text { per gram }\end{array}$ & $1.1 \times 10^{-3} \mathrm{M} \mathrm{I}_{2}^{\mathrm{d}}$ & ح100 & 0.02 \\
\hline \multirow[t]{8}{*}{13()} & Amlerlite XAD-2 & Bial[che exfuil & $\begin{array}{l}\text { Contact, } \\
\text { J6 lor }\end{array}$ & $N)^{e}$ & $\begin{array}{l}5 \times 10^{-5} \mathrm{M} \mathrm{I}_{2} \\
\mathrm{In}_{2} \mathrm{O}\end{array}$ & $\mathrm{DR}=31$ & Batch \\
\hline & Amiserlite $x N \mid)-4$ & Batceh exquil & $\begin{array}{l}\text { Contact, } \\
\text { If lir }\end{array}$ & N]J & $\begin{array}{l}5 \times 10^{-5} \mathrm{M} \mathrm{I}_{2} \\
\text { in } \mathrm{H}_{2} \mathrm{O}\end{array}$ & $\mathrm{DR}=25$ & Batch \\
\hline & Amberlite $X A J)-S$ & Bistuh equil & $\begin{array}{l}\text { Contalct, } \\
16 \mathrm{hr}\end{array}$ & ND & $\begin{array}{l}5 \times 10^{-5} \\
\text { in } \mathrm{H}_{2} \mathrm{O}\end{array}$ & $D R=18$ & Batch \\
\hline & Amberlite $X A \mid)-12$ & Biatell cequil & $\begin{array}{l}\text { Contiact, } \\
16 \mathrm{irr}\end{array}$ & $\mathrm{ND}$ & $\begin{array}{l}5 \times 10^{-5} \mathrm{MI}_{2} \\
\mathrm{in} \mathrm{H}_{2} \mathrm{O}\end{array}$ & $D R=24000$ & Batch \\
\hline & Amberlite $X A \mid)-2$ & Bialche equil & $\begin{array}{l}\text { Contiace, } \\
\text { Jis hir }\end{array}$ & $\mathrm{NIJ}$ & $\begin{array}{l}5 \times 10^{-5} \mathrm{M} \mathrm{I}_{2} \\
\text { in o.J M } \mathrm{HNO}_{3}\end{array}$ & $D R=1100$ & Batch \\
\hline & Amberl i $(e . X A 1)-4$ & lsiatcle equil & $\begin{array}{l}\text { contiact, } \\
\text {.15 lis }\end{array}$ & ND & $\begin{array}{l}5 \times 10^{-5} \mathrm{M} \mathrm{I}_{2} \\
\mathrm{in} 0.1 \underline{\mathrm{MNO}} 3\end{array}$ & $\mathrm{DR}=390$ & Batch \\
\hline & AmlyerliL(c $X A \mid)-Y$ & Batche enuli & $\begin{array}{l}\text { Comlaret, } \\
16 \mathrm{hr}\end{array}$ & $\mathrm{NI})$ & $\begin{array}{l}5 \times 10^{-5} \mathrm{MI}_{2} \\
\mathrm{in}_{\mathrm{N}} 0.1 \mathrm{M} \mathrm{HNO}_{3}\end{array}$ & $D R=1200$ & Batch \\
\hline & Amberlit(G XN)-12 & Binteli eqquil & $\begin{array}{l}\text { Contir.t. } \\
\text { is irr }\end{array}$ & Ni) & $\begin{array}{l}5 \times 10^{-5} \mathrm{M}_{2}{ }_{2} \\
\ln 0.1 . \mathrm{MNO}\end{array}$ & $\mathrm{DR}=720$ & Batch \\
\hline \multirow[t]{3}{*}{131} & sinlserlice $x A B)-12$ & $0.4 \times 15 \mathrm{~cm}$ & $\begin{array}{l}15 \text { min; } \\
\text { runduration, } \\
120 \text { lir }\end{array}$ & $77 \mathrm{mg} / \mathrm{cm}^{3}$ & $\begin{array}{l}5 \times 10^{-4} \mathrm{M}^{1}{ }_{2} \\
\text { in } \mathrm{H}_{2} \mathrm{O}\end{array}$ & $100^{2}-10^{3}$ & 0.01 \\
\hline & . & $11.4 \times 15 \mathrm{~cm}$ & $\begin{array}{l}3.75 \mathrm{ming} ; \\
\text { run lime, } 48 \text { lor }\end{array}$ & $130 \mathrm{mg} / \mathrm{cm}^{3}$ & $\begin{array}{l}5 \times 10^{-4} \mathrm{MI} \mathrm{I}_{2} \\
\mathrm{In}_{2} \mathrm{O}\end{array}$ & $10^{2}-10^{3}$ & 0.04 \\
\hline & & $0.4 \times 1010 \mathrm{~m}$ & $\begin{array}{l}6.9 \text { min: run } \\
\text { time, } 17 \text { ditys }\end{array}$ & Ni) & $\begin{array}{l}1 \times 10^{-6} \mathrm{M} 1_{2} \\
\text { in } H_{2} O\end{array}$ & $50-100)$ & 0.017 \\
\hline \multirow[t]{2}{*}{132} & Araberlite Xab)-4 & $0.4 \times 25 \mathrm{~cm}$ & $\begin{array}{l}\text { h. } 28 \text { mins: } \\
\text { run time', 50 hr }\end{array}$ & (h) & $\begin{array}{lll}5 \times 10^{-4} & \mathrm{M}_{2} \mathrm{~T}_{2} \\
\mathrm{in} 0.5 \mathrm{M} \mathrm{liNO}_{3}\end{array}$ & $14-25$ & 0.04 \\
\hline & & $0.4 \times 25 \mathrm{~cm}$ & $\begin{array}{l}6.28 \mathrm{~min} ; \\
\text { run time, } 50 \text { lir }\end{array}$ & $0.51) \mathrm{m} m /(1 \mathrm{~m})^{3}$ & 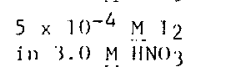 & $\begin{array}{l}10^{2} \text { dectreisting } \\
103\end{array}$ & 0.04 \\
\hline 133 & Anberlite $X A \mid J-12$ & $0.4 \times 150 \mathrm{~m}$ & $\begin{array}{l}1.5 \operatorname{min:} \\
\text { run Limer, } 47 \mathrm{lrr}\end{array}$ & $N \underbrace{N]}$ & $\begin{array}{l}1 \times 10^{-6} M 1_{2} \\
\text { in } H_{2} 0\end{array}$ & 50 & 0.1 \\
\hline
\end{tabular}


Table 12. Macroreticular resins tested to determine the optimum sorbent for removing iodine from neutral and nitric acid solutions

\begin{tabular}{|c|c|}
\hline Sorbent & Type of plastic \\
\hline Bio-Bead SM-1 ${ }^{a}$ & Polystyrene \\
\hline Bio-Bead $S M-2^{a}$ & Polystyrene \\
\hline \multicolumn{2}{|c|}{ Amberlite series ${ }^{b}$} \\
\hline $\mathrm{XAD}-2$ & Styrene-DVB \\
\hline $\mathrm{XAD}-4$ & Styrene-DVB \\
\hline $\mathrm{XAD}-7$ & Acrylic ester \\
\hline $\mathrm{XAD}-8$ & Acrylic ester \\
\hline $\mathrm{XAD}-9$ & Acrylic ester-sulfoxide \\
\hline $\mathrm{XAD}-11$ & Acrylamide polymer \\
\hline $\mathrm{XAD}-12$ & $\begin{array}{l}\text { Acrylic ester with nitrogen- } \\
\text { oxygen group }\end{array}$ \\
\hline$X E-284$ & Styrene-DVB-sulfonic acid \\
\hline \multicolumn{2}{|c|}{$\begin{array}{l}\text { Approximately } 0.1 \mathrm{~g} \text { of resin was contacted for } 16 \mathrm{hr} \\
\text { with } 10 \mathrm{ml} \text { of solution containing } 5 \times 10^{-5} \mathrm{M} \mathrm{I}_{2} \text { traced } \\
\text { with } 131_{\mathrm{I}} \text {. The distribution ratio was counts min-1 } \mathrm{g}^{-1} \\
\text { resin/(counts } \mathrm{min}^{-1} \mathrm{ml}^{-1} \text { aqueous) } .130\end{array}$} \\
\hline \multicolumn{2}{|c|}{$\begin{array}{l}\text { a Bio-Bead macroreticular resins are available from } \\
\text { Bio-Rad, Inc. }\end{array}$} \\
\hline
\end{tabular}


shown in Table 11. In later tests with the $X A D-2, X A D-4$, and $X A D-12$ resins in packed beds, it was never possible to obtain iodine DFs in dynamic bed operation that could compare to the distribution found for batch equili-

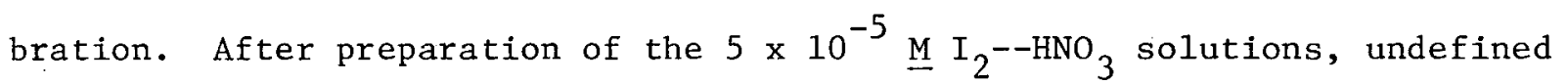
species of iodine resulted in significantly reduced distribution ratios unless the solution was aged $24 \mathrm{hr}$. It was reported ${ }^{114}$ that after several hours in $3.0 \mathrm{M} \mathrm{HNO}_{3}$, virtually all dissolved iodine would be present as elemental iodine (with $\mathrm{I}_{3}^{-}$as an intermediate from $\mathrm{I}^{-}$). Thus after initial preparation of the iodine-nitric acid solutions, aging was recommended 130 to be sure that all ionic-iodine had been oxidized to elemental iodine. However, for a dilute acidic solution, there is a strong possibility that some of the iodine will be in ionic form $\left(\mathrm{I}_{3}{ }^{-}\right)$at equilibrium. The presence of this species could reduce the DFs for sorbents with an affinity for molecular iodine only. Based on the chemical mechanism operating in the macroreticular resins, it is possible that a serious reduction in $\mathrm{DF}$ for iodine could be due to the growth of ionic species $\left(\mathrm{I}^{-}, \mathrm{IO}^{-}, \mathrm{IO}_{3}^{-}, \mathrm{I}_{3}^{-}\right.$) into elemental iodine solutions.

Moore and Howerton ${ }^{131}$ also determined the loading capacity and DF produced with XAD-12 for removing iodine from water, and the effective techniques for regenerating XAD-12 in situ in packed beds. For a 0.4 by $15-\mathrm{cm}$ column of XAD-12 fed at flow rates of $0.01 \mathrm{~m} / \mathrm{min}$ and $0.04 \mathrm{~m} / \mathrm{min}$, DFs of $10^{2}$ to $10^{3}$ were obtained when iodine was removed from $5 \times 10^{-4} \underline{\mathrm{M} \mathrm{I}}_{2}$ in aqueous solution. Long run times were $120 \mathrm{hr}$ and $48 \mathrm{hr}$ for $0.01 \mathrm{~m} / \mathrm{min}$ and $0.04 \mathrm{~m} / \mathrm{min}$ respectively. For three sorption cycles of the XAD-12 columns, 85 to $94 \%$ of the sorbed iodine.could be eluted with a $0.1 \underline{\mathrm{M}} \mathrm{Na}_{2} \mathrm{~S}_{2} \mathrm{O}_{3}-0.1 \underline{\mathrm{M}} \mathrm{NaOH}$ solution. However, the $\mathrm{DF}$ for removing 
iodine from $10^{-6} \mathrm{M} \mathrm{I}_{2}$ in aqueous solution was reduced to about 50, which was a possible indication that the iodine DF decreased as the feed concentration decreased. (This would be consistent with the observation that at low molarity of elemental iodine in aqueous solution, the elemental iodine becomes more unstable and dissociates to $\mathrm{I}^{-}$and $\mathrm{I}_{3}{ }^{-}$, which have less affinity for macroreticular resins than does elemental iodine.) In agreement with later work at BNWL, it was also noted that preloading of the $\mathrm{XAD}-12$ with nonradioactive elemental iodine appeared to enhance the iodine removal efficiency that could be obtained for the $10^{-6} \underline{\mathrm{M}} \mathrm{I}_{2}$ aqueous feed.

In summary, it appeared that the sorbent XAD-12 was the most efficient macroreticular resin for sorption of iodine from very dilute aqueous solutions. This effect might occur because of a slightly greater affinity of XAD-12 for $\mathrm{I}_{3}{ }^{-}$and $\mathrm{I}^{-}$than is found for the other resin forms. The active group for XAD-12 was acrylic ester with a nitrogen-oxygen group.

Because earlier batch equilibration experiments had suggested that XAD-4 was the most efficient sorbent for iodine removal from nitric acid solutions, the $\mathrm{XAD}-4$ resin was utilized in a $0.4-$ by $25-\mathrm{cm}-1$ long column to sorb iodine from a feed of $5 \times 10^{-4} \underline{\mathrm{M} \mathrm{I}} 2$ in $0.5 \mathrm{M} \mathrm{HNO}_{3} \cdot 132$ The column DF for iodine varied from 14 to 25 , increasing with increasing run time, and was maintained for 500-bed volumes of the feed. Only about $75 \%$ of the iodine could be removed from the column with $0.2 \underline{M}$ $\mathrm{NaOH}$. Some loss in capacity and DF occurred after regeneration. When the concentration of the feed was increased to $3.0 \underline{\mathrm{M}} \mathrm{HNO}_{3}$, DFs of as much as 100 were obtained; however, after 250-column volumes were fed 
to the column, this DF was reduced to only 3.0 . Thus the effect of increasing the nitric acid concentration in the feed for long run times was to decrease the capacity of the $\mathrm{XAD}-4$ resin for which a $\mathrm{DF}$ of 25 could be maintained. The $3.0 \mathrm{M} \mathrm{HNO}_{3}$ feed affected the regeneration of the XAD-4 more than did the $0.5 \underline{\mathrm{M}} \mathrm{HNO}_{3}$ feed. Comparative studies of the sorption characteristics of charcoal, XAD-12, and silver zeolite were performed with $1 \times 10^{-6} \underline{\mathrm{M}} \mathrm{I}_{2}$ aqueous solutions; Table 13 shows that the best results were obtained with the activated coconut charcoal.

Table 13. Comparison of DFs obtained for removal of $I_{2}$ from aqueous solution using activated charcoal, silver zeolite, and Amberlite XAD-12

Conditions: bed size, $0.4 \times 10 \mathrm{~cm}$; loading capacity, not determined; feed, $1 \times 10^{-6} \underline{\mathrm{M}} \mathrm{I}_{2}$ in aqueous; temp, $21^{\circ} \mathrm{C}$

\begin{tabular}{llc}
\hline \multicolumn{1}{c}{ Sorbent } & DF & $\begin{array}{c}\text { Superficial } \\
\text { velocity } \\
\text { (m/min) }\end{array}$ \\
\hline $132 \quad \begin{array}{l}20 \text { to } 50 \text { mesh, } \\
\text { Fisher 5-685-A } \\
\text { activated coconut } \\
\text { charcoal }\end{array}$ & $10^{4}$ & 0.15 \\
$\begin{array}{l}\text { Silver zeolite, } \\
20 \text { to 50 mesh }\end{array}$ & 33 & 0.016 \\
Amberlite XAD-12 & 143 & 0.08 \\
\hline
\end{tabular}


It has previously been noted that for $10^{-6} \mathrm{M} \mathrm{I}_{2}$ in $\mathrm{H}_{2} \mathrm{O}$, most of the iodine will exist as elemental $I_{2}$, but there may be small quantities of ionic species such as $\mathrm{I}_{3}{ }^{-}$and $\mathrm{I}^{-}$(Table 9). Thus the achievement of the highest DF for iodine on the activated coconut charcoal may have occurred because the charcoal had a similar capacity for elemental $\mathrm{I}_{2}$ as did zeolites and XAD-12; however, it had a greater capacity for $\mathrm{I}^{-}$species. When an aqueous solution of $1 \times 10^{-6} \underline{\mathrm{M}} \mathrm{I}_{2}$ was fed to a 0.4 by $15-\mathrm{cm}-$ long column of XAD-12, a DF of about 50 was obtained for 1700-bed volumes of feed. Methanol did not show much promise as a column regenerating solution. 133

Various polymeric and anion exchange resins have been screened to determine their capability of removing iodine species from simulated fuel reprocessing plant low-level aqueous effluent streams. ${ }^{134-136}$ The following operational characteristics for long-term column tests with the Amberlite XAD series of macroreticular resins were observed:

1. The column efficiency obtained for iodine removal was negatively affected by intermittent operation.

2. In beds preloaded with iodine in continuous flow operation, more iodine was eluted from the XAD-7 and $\mathrm{XAD}-8$ resins than from $\mathrm{XAD}-2$ and $\mathrm{XAD}-4$ resins. This result was somewhat at variance with the batch distribution results of Moore and Howerton ${ }^{130}$ in which the amount of iodine sorbed from aqueous solution per gram of resin was about the same for the four resins $\mathrm{XAD}-2, \mathrm{XAD}-4, \mathrm{XAD}-7$, and $\mathrm{XAD}-8$. 
3. Only partially successful regeneration of the Amberlite $\mathrm{XAD}-$ resins could be obtained with solutions of $0.1 \underline{\mathrm{M}}$ $\mathrm{Na}_{2} \mathrm{SO}_{3}$ and $0.1 \mathrm{M} \mathrm{NaOH}$. In the most successful regeneration test, $85 \%$ of the sorbed iodine was removed from a preloaded XAD-2 resin bed. Moore and Howerton ${ }^{131}$ had obtained recoveries of 85 to $94 \%$ of the iodine loaded onto Amberlite XAD-12 beds. However, using $0.2 \underline{\mathrm{M}} \mathrm{NaOH}$, they obtained recoveries of only 53 to $65 \%$ of preloaded iodine from Amberlite XAD-4 beds. ${ }^{132}$ In general, the elemental iodine sorbed on macroreticular resins should be reduced by $\mathrm{NaOH}$ to $\mathrm{I}^{-}$, which has very little affinity for the resin and thus is eluted from the bed.

4. Prewashing of the $\mathrm{XAD}-4$ resins with organic solvents prior to loading could enhance the removal efficiency of molecular iodine.

5. The elemental iodine removal efficiency of the XADresins was enhanced by adding $\mathrm{H}_{2} \mathrm{O}_{2}$ to the feed to oxidize any iodide ion to elemental iodine. ${ }^{136}$ It was previously reported in the discussion of Moore's work $^{129-133}$ that macroreticular resins had much greater attraction for elemental iodine than for iodide ions in aqueous solutions. Swanson ${ }^{136}$ concluded that some chemical grouping in the commercial Amberlite $\mathrm{XAD}-\mathrm{resins}$ exerted a reducing effect on the elemental iodine in the dilute acidic feeds. The nullifying effect of $\mathrm{H}_{2} \mathrm{O}_{2}$ on this reductant is shown 
in Table 14. It was concluded that there was little possibility of achieving high DFs for elemental iodine on macroreticular resins for peroxide concentrations substantially below $0.3 \mathrm{M}$; in fact, the addition of $0.3 \underline{\mathrm{M}} \mathrm{H}_{2} \mathrm{O}_{2}$ to the entire low-level aqueous waste stream from a large-scale LWR fuel reprocessing plant would carry a severe economic penalty. The reductant effect on $\mathrm{I}_{2}$ apparently exerted by the macroreticular resins could possibly be counteracted by adding a low concentration of ferric ion and $\mathrm{H}_{2} \mathrm{O}_{2}$ to the feed, or by adding a trace of nitrite to the feed. The reduction in DF for removal of iodine from dilute acidic solutions using macroreticular resins may also be attributed to the dissociation of iodine in acidic solutions. Davis and Kibbey ${ }^{114}$ (also see Table 9) reported that the equilibrium quantity of $\mathrm{I}_{3}{ }^{-}$is $1.65 \%$ of total iodine for $10^{-3} \underline{\mathrm{M} \mathrm{I}}_{2}$ in $0.025 \underline{\mathrm{M} \mathrm{HNO}} 3$, and up to $2 \%$ of iodine for $10^{-3} \mathrm{M} \mathrm{I}_{2}$ in $0.1 \mathrm{M} \mathrm{HNO}_{3}$. Thus for a sorbent that is reactive with primarily elemental iodine $\mathrm{I}_{2}$ but not ionic iodine $\mathrm{I}_{3}{ }^{-}$, the maximum DF that could be achieved for the concentrations of 0.025 to $0.1 \underline{\mathrm{M}}_{3} \mathrm{HNO}_{3}$ would be $\leq 50$ (without the presence of an oxidizing agent).

6. Preliminary results suggested that the DF for molecular iodine removal on $\mathrm{XAD}-4$ was reduced slightly by dissolved organics (TBP and NPH diluents were used). 
Table 14. The effect of hydrogen peroxide concentration on the sorption of iodine from a dilute nitric acid solution ${ }^{\mathrm{a}}$

Column conditions: Aqueous flow rate, 2 column vol/ hr; column dimensions, 0.9 by $19 \mathrm{~cm}$; temp, $20^{\circ} \mathrm{C}$; feed, $1 \times 10^{-5} \underline{\mathrm{M}} \mathrm{I}_{2}, 0.05 \underline{\mathrm{M}} \mathrm{HNO}_{3}, \mathrm{H}_{2} \mathrm{O}_{2}$ as indicated

\begin{tabular}{|c|c|c|}
\hline $\begin{array}{l}\text { Total column } \\
\text { volumes applied }\end{array}$ & $\begin{array}{c}\mathrm{H}_{2} \mathrm{O}_{2} \text { conc in feed } \\
(\mathrm{M})\end{array}$ & $\begin{array}{l}\mathrm{DF} \text { for } \\
\text { iodine } \\
\text { on } \mathrm{XAD}-4^{\mathrm{b}}\end{array}$ \\
\hline 65 & 0.3 & 350 \\
\hline 125 & 0.1 & 32 \\
\hline 175 & 0.03 & 6 \\
\hline 220 & 0.3 & 120 \\
\hline \multicolumn{3}{|c|}{$\begin{array}{l}\mathrm{a}_{\text {This information was taken from ref. } 136 .} \\
\mathrm{b}_{\mathrm{DF}}=\text { iodine concentration in feed/(iodine concentration } \\
\text { in effluent). The data were obtained by applying the } \\
\text { following feed schedule: } 65 \text { column volumes containing } \\
0.3 \mathrm{M} \mathrm{H}_{2} \mathrm{O}_{2} ; 60 \text { column volumes containing } 0.1 \mathrm{M} \mathrm{H}_{2} \mathrm{O}_{2} \text {; } \\
50 \text { columns containing } 0.03 \mathrm{M}_{2} \mathrm{O}_{2} \text {; and } 45 \text { column } \\
\text { volumes containing } 0.3 \underline{\mathrm{M}} \mathrm{H}_{2} \mathrm{O}_{2} \text {. }\end{array}$} \\
\hline
\end{tabular}

\subsubsection{Present applications}

All utilizations of macroreticular resins for removing iodine species from aqueous waste streams have been experimental and are conclusively summarized above.

\subsubsection{Process capacity}

The maximum loading obtained by Moore and Howerton ${ }^{132}$ for removal of molecular iodine from $0.5 \underline{\mathrm{MNO}}_{3}$ solutions with Amberlite XAD-4 macroreticular resin was about $60-\mathrm{mg} \mathrm{I}_{2} / \mathrm{cm}^{3} \mathrm{XAD}-4$. The iodine loading 
obtained by Swanson ${ }^{136}$ when XAD-4 was used to remove iodine from $0.05 \underline{\mathrm{M}}$ $\mathrm{HNO}_{3}, 0.3 \mathrm{M} \mathrm{H}_{2} \mathrm{O}_{2}$ solutions was only $0.5-\mathrm{mg} \mathrm{I}_{2} / \mathrm{cm}^{3} \mathrm{XAD}-4$. The differences in the loading capacities can be partly attributed to the differences in operating conditions:

$\begin{array}{lll} & \frac{\text { Ref. } 132}{10^{-4} \underline{M}} & \frac{\text { Ref. } 136}{10^{-5} \underline{M}} \\ I_{2} \text { feed conc } & 0.04 \mathrm{~m} / \mathrm{min} & 0.0063 \mathrm{~m} / \mathrm{min} \\ \text { Flow rate } & 60 \mathrm{mg} \mathrm{I} / \mathrm{cm}^{3} & 0.5 \mathrm{mg} \mathrm{I} \mathrm{I}_{2} / \mathrm{cm}^{3} \\ \text { Loading capacity } & <100 & >100 \\ \text { DF maintained } & 3 \mathrm{~cm}^{3} & 12 \mathrm{~cm}^{3} \\ \text { Bed size } & & \end{array}$

Perhaps the loading capacity of XAD-4 for iodine obtained by Swanson ${ }^{136}$ would have equalled that obtained by Moore ${ }^{132}$ if the run time in Swanson's tests had been extended to supply the same quantity of iodine per $\mathrm{cm}^{3}$ of bed as that attained by Moore.

\subsubsection{Process advantages}

1. If operated in ascending flow, the macroreticular resins have good flow characteristics. The beads maintain their physical integrity, should be thermally resistant to $250^{\circ} \mathrm{C}$, and are acid resistant, particularly to $\mathrm{HNO}_{3}$ which is the acidic component of actual low-1evel liquid wastes from reprocessing plants.

2. The macroreticular resins may be sufficiently stable to be considered for burial when they become excessively contaminated from unregenerable iodine. 
3. The macroreticular resins offer some promise of regneration, because they are compatible with solutions of methanol, $\mathrm{Na}_{2} \mathrm{SO}_{3}$, and $\mathrm{NaOH}$.

\subsubsection{Process disadvantages}

1. The low density of the macroreticular beads requires careful hydrodynamic control, and there may be some problems involved with in situ regeneration of the resins in columns.

2. Further tests of the competitive effect of organics on iodine binding should be pursued because macroreticular resins are primarily noted for their capacity to sorb organics.

3. The performance of the macroreticular resins has not been established as a function of temperature.

4. Resins that perform well for iodine removal from dilute nitric acid streams usually lose iodine when washed with neutral solutions.

5. All studies made with the macroreticular resins were to ascertain their efficiency for removal of iodine from neutral and dilute nitric acid aqueous streams, but no studies have been directed toward determining the capability of the resins to sorb organic iodides from the aqueous feeds. However, due to their lack of solubility in aqueous solutions, such low levels of organic iodides may be present that they may not 
constitute a serious problem. Removal of organic iodides could probably best be handled by volatilizing and then sorbing them from humid vapors on silverexchanged mordenites or the German Ag-KTB (AC-6120) material.

6. The process DFs and loading capacities obtained for iodine from low concentration feeds $\left(<10^{-4} \underline{\mathrm{M}} \mathrm{I}_{2}\right)$ appear to be strongly related to the presence of iodides (and the resultant loss of elemental iodine) in the feeds and while exposed to the resins in the column. Unless this loss of process DF for total iodine can be solved simply without extensive and expensive chemical oxidant addition, the use of macroreticular resins for iodine removal from dilute acidic streams with very low iodine concentrations may remain too inefficient to compete with sorption on charcoal or anion exchange resins.

7. Any additional studies should be conducted in engineering-sized equipment.

\subsection{Removal of Iodine Species from Aqueous Streams by Utilizing} Anion Exchange Resins

\subsubsection{Background}

The treatment of aqueous streams for removal of iodine by ion exchange is a process widely used by operators of nuclear power plants to minimize the environmental impact of radionuclides that could be 
discharged into surface waters. Because there are many cationic and anionic radionuclides in the primary and secondary coolants, coolant condensates, and liquid wastes in nuclear power plants, iodine removal has generally not been studied as a specific problem. However, based on the information derived from the utilities using nuclear power generation, general information concerning the interaction of iodine with ion exchange resins can be obtained. Only a few laboratory studies, primarily in relation to removal of iodine from liquid wastes associated with nuclear reactors, have been conducted. In general, the best iodine removal efficiencies were found for anion exchange resins at neutral or slightly acidic pH. Competitive anions reduced the DF and loading capacity which could be obtained for iodine and, in many cases, an increase in acid concentration reduced the quantity of iodide sorbed. These results appear to be consistent with the studies reported by Davis and Kibbey ${ }^{114}$ (also see Table 9) describing the iodine species that apparently exist in $\mathrm{HNO}_{3}$ solutions. In general, when iodide $\left(\mathrm{I}^{-}\right)$is dissolved in $\mathrm{HNO}_{3}$, it is oxidized to elemental iodine. Thus, for $\mathrm{I}^{-}$in $\mathrm{HNO}_{3}$ solutions (or any other strongly acidic solution), as the concentration of acid is increased, the amount of iodine as elemental $\mathrm{I}_{2}$ will increase and iodine as $\mathrm{I}^{-}$or $\mathrm{I}_{3}^{-}$will decrease. Therefore, the amount of iodine removed by an anion exchanger should decrease as the acid concentration increases ( $\mathrm{pH}$ decreases). Apparently, very 1ittle consideration has been given to using anion exchange resins for iodide removal from liquids by designers of nuclear fuel reprocessing plants. 


\subsubsection{Chemical mechanism}

Although no references satisfactorily described the specific chemical kinetics and stoichiometry of the interaction between iodide and anion exchange resins, useful mechanistic information may be gleaned from the following studies.

Ivanov $^{137}$ studied the sorption of molecular iodine from aqueous solutions in batch equilibrations with various salt forms of the highly basic anion exchanger AV-17. The iodine concentrations were 5 to 50 millimolar (in excess $\mathrm{KI}$ ) in aqueous solution at $\mathrm{pH} 6.4$. Thus the iodine was available in both the iodide and elemental $I_{2}$ forms. The differences in the iodine sorption capacities of the various forms of the resin were attributed to the affinities of the ions to the sorbent and their redox potentials with respect to iodine. The amounts of iodine sorbed as iodide by the exchanged resin were in the range 3 to $7 \mathrm{millimoles}$ of iodine/g resin, or 0.38 to $0.90-\mathrm{g} \mathrm{I}^{-} / \mathrm{g}$ resin. For the halide forms of the resin, sorption of iodine varied according to the sequence $\mathrm{AV}-17 \mathrm{Cl}^{-}>\mathrm{AV}-17 \mathrm{Br}^{-}>$ AV-17 $\mathrm{I}^{-}$. That is, of the halides, iodide had the greatest affinity for the resin. Among a wide range of salts tested, the largest amount of iodine was sorbed by the $\mathrm{AV}-17$ resin in the $\mathrm{SCN}^{-}$form, and the smallest amount was sorbed by the $\mathrm{IO}_{3}{ }^{-}, \mathrm{I}^{-}$, and $\left[\mathrm{Fe}(\mathrm{CN})_{6}\right]^{-4}$ forms. Among the proposed reactions were:

$$
\begin{gathered}
2 \mathrm{SCN}^{-}+\mathrm{I}_{2}=2 \mathrm{I}^{-}+(\mathrm{SCN})_{2} \\
\mathrm{IO}_{3}^{-}+5 \mathrm{I}^{-}+6 \mathrm{H}^{+}=3 \mathrm{I}_{2}+3 \mathrm{H}_{2} \mathrm{O} \\
2\left[\mathrm{Fe}(\mathrm{CN})_{6}\right]^{-4}+\mathrm{I}_{2}=2\left[\mathrm{Fe}(\mathrm{CN})_{6}\right]^{-3}+2 \mathrm{I}^{-} .
\end{gathered}
$$


The reducing agents $\mathrm{SCN}^{-}$and $\left[\mathrm{Fe}(\mathrm{CN})_{6}\right]^{-4}$ were oxidized, which resulted in a decrease in the amount of elemental iodine in the aqueous solution and a corresponding increase in iodide sorption. Iodine was normally desorbed from the resin with $10 \% \mathrm{KOH}$ solutions. The iodine was desorbed least from the $\mathrm{SO}_{4}^{-2}, \mathrm{CO}_{3}^{-2}, \mathrm{CH}_{3} \mathrm{COO}^{-2}$, and $\mathrm{PO}_{4}^{-3}$ forms of the resin.

In summary, to maximize the absorption of iodine from aqueous iodide solutions at $\mathrm{pH}=6.4$, the highly basic anion exchanger AV-17 was most efficient in either the chloride form or with a highly active reductant group such as $\mathrm{SCN}^{-}$. The sorption capacity obtained for iodide depended on the affinity of the resin for the counter ion of the original resin form, the species of iodine present in the solution, and the side reactions accompanying the absorption of iodide ion.

\subsubsection{Experimental results and engineering data useful for process design Laboratory tests of iodine species removal from aqueous streams with} ion exchange materials. To determine the applicability of gel-type ion exchange resins for the decontamination of radionuclides in cooling water of nuclear reactors, Yokotsuka et al. ${ }^{138}$ studied the distribution of 42 inorganic ions, including $\mathrm{Na}^{131} \mathrm{I}$, between neutral or acidic solutions and several gel types of Diaion and Amberlite ion exchangers. For batch equilibration tests with $\mathrm{Na}^{131} \mathrm{I}$, the anion exchange resins (in gel form) Diaion SAN-1 and Amberlite IRN-78 (for resin properties, see Table 15) showed good removal efficiency (distribution ratio of $10^{1}$ to $10^{2}$ ) for iodide ion in hydrochloric acid solutions varying from 0 to $12 \underline{\mathrm{M}}$.

In a related study to determine the relative merits of the gel and porous forms of the resins for use in filtering nuclear reactor coolants, 
Table 15. Properties of anion exchange resins of the tetramethylammonium chloride form

\begin{tabular}{lcccc}
\hline \multicolumn{1}{c}{ Resin } & $\begin{array}{c}\text { Particle } \\
\text { size }\end{array}$ & $\begin{array}{c}\text { Diviny1- } \\
\text { benzene } \\
(\%)\end{array}$ & $\begin{array}{c}\text { Weight } \\
\text { exchange } \\
\text { capacity } \\
\text { (meq/g) }\end{array}$ & $\begin{array}{c}\text { Volume } \\
\text { exchange } \\
\text { capacity } \\
\text { (meq/ml) }\end{array}$ \\
\hline Diaion SAN-1 & 20 to 50 mesh & 8 & 2.61 & 1.07 \\
Amberlite IRN-78 & 20 to 50 mesh & 8 & 2.77 & 1.09 \\
Diaion PA-316 & 0.35 to $0.55 \mathrm{~mm}$ & 8 & 3.91 & 1.46 \\
Amberlite IRA-900 & $\mathrm{NS}$ & 10 & 3.80 & 1.03 \\
\hline
\end{tabular}

$a_{\text {NS, not specified. }}$

Akatsu $^{139}$ investigated the iodide removal efficiencies and flow properties of porous'forms of the Diaion and Amberlite series. Good distribution ratios ${ }^{*}$ were determined for batch equilibration of iodine as $\mathrm{Na}^{131} \mathrm{I}$ in acidic solutions and the anion exchangers Amberlite IRA-900 and Diaion PA-316. For both of these anion exchangers in the chloride form, the distribution ratio decreased from $10^{3}$ to $10^{2}$ when the concentration was increased from 0.1 to $1.0 \mathrm{~N} \mathrm{HCl}$. The iodide distribution ratios between water and the anion exchangers Diaion PA-316 and Amber1ite IRA-900 were $1 \times 10^{3}$ and $2 \times 10^{3}$ respectively. Skorokhod ${ }^{140}$ had also reported good iodine removal efficiencies with another Amberlite resin, the strongly basic anion polystyrene ion exchanger IRA-410. In the studies described

\footnotetext{
* Batch distribution ratio, $\mathrm{Kd}(\mathrm{ml} / \mathrm{g})$, was counting rate of initial soln (per $\mathrm{ml}$ ) $\mathrm{Kd}=\frac{\text { volume of aqueous phase }}{\text { weight of air dried resin }} \times \frac{\text { minus that of final soln (per } \mathrm{m} 1 \text { ) }}{\text { counting rate of final soln (per m1) }}$
} 
in refs. 138 and 139 , none of the cation exchangers used showed any iodine adsorption from aqueous or acidic solutions of 0 to $1.0 \mathrm{~N} \mathrm{HC}$. This result had already been shown in tests of Dowex cation exchange resins for removing radionuclides from 0 to 12.0 N $\mathrm{HCl}$ solutions. ${ }^{141}$

A rather unique application of ion exchange resins for iodine sorption involved experiments to develop methods of purifying milk containing radionuclides. ${ }^{142}$ Radionuclides such as ${ }^{90} \mathrm{Sr}$ and ${ }^{131^{\circ}} \mathrm{I}^{-}$could be introduced into milk from nuclear weapons fallout. Studies were conducted at both the pilot plant and on a commercial scale to determine the efficiency of sequential anion and cation exchange beds for removing ${ }^{90} \mathrm{Sr}$ and ${ }^{131} \mathrm{I}^{-}$. Operating conditions included a temperature of $10^{\circ} \mathrm{C}$, a pH of 5.3 adjusted with either citric acid or hydrochloric acid, the anion exchanger DOWEX $2 \times 8,20$ to 50 mesh, equilibrated primarily with the chloride and citrate anions, and the cation exchanger IR-120 equilibrated primarily with the calcium cation, and to a lesser capacity with the potassium, sodium, and magnesium cations. Flow rates for the $65-$ by $224-\mathrm{cm}$ anion exchange bed were in the range 0.05 to $0.1 \mathrm{~m} / \mathrm{min}$ $(1 / 16$ to $1 / 8$ resin-bed volumes/min). For three commercial-scale runs with series operation of the anion-cation exchange resin beds, an average of $99.3 \%$ of ${ }^{131}$ I was removed by the anion exchanger. Apparently, one workable method of removing iodine species from aqueous process streams would be to first reduce the iodine species to iodine ions and then remove them on anion exchange resins. Anion exchangers such as Amberlite IRN-78, Amber1ite IRA-900, Amberlite IRA-410, and Diaion PA-316 have shown promising affinity for iodide. Swanson ${ }^{143}$ has recently studied the removal of iodide from $1 \times 10^{-5} \underline{\mathrm{M}} \mathrm{I}^{-}$in $\mathrm{HNO}_{3}$ 
solutions on small columns $\left(\sim 12 \mathrm{~cm}^{3}\right)$ of the Rohm and Haas anion exchange resins: Amberlyst A-26, Amber1ite IRA-910, Amberlite IRA-900, Amber1ite IRA-94, and Amberlyst A-21. The best DFs (>10) and iodide loading capacities were obtained for the first three anion exchangers. The iodide removal from nitrate solutions using the IRA-900 increased when the nitrate concentration of the feed solution was decreased; for example, the iodide capacity of IRA-900 increased by a factor of 5 when the nitrate concentration was reduced from 0.05 to $0.01 \underline{\mathrm{M}}$. This effect appears to be consistent with a reduction in oxidation of $\mathrm{I}^{-}$to elemental $\mathrm{I}_{2}$ as shown in Table 9. That is, when nitrate concentration is decreased from 0.05 to $0.01 \underline{\mathrm{M}}$, relatively more of the total iodine is found as the iodide ion rather than in elemental form. Subsequently, the capacity of the anion exchange resin for iodine as $\mathrm{I}^{-}$should be increased. It is possible that one method of regenerating the iodideloaded anion exchangers would be to elute them with 2 to $3 \underline{\mathrm{M}} \mathrm{HNO}_{3}$ solutions.

Other less orthodox adsorbents have been suggested for removal of iodine species from aqueous solutions. In general, these sorbents are not likely to be considered as viable alternatives for low-level radwaste streams, because either additional definitive experiments are necessary or preliminary efficiencies were not promising. Zuljevic ${ }^{144}$ reported that iodide ions are partially sorbed to ferric hydroxide precipitates prepared by mixing $\mathrm{FeCl}_{3}$ and $\mathrm{NH}_{3}$ solutions. Poor loading capacity and undefined sorbent hydrodynamics appear to limit further application of this adsorbent. Brevnova et al. ${ }^{145}$ investigated the utilization of isotopic exchange for isolating iodine from fission products in a 1.5-cm-ID 
column containing fibrous sulfonate ion exchangers treated with $10 \%$ solutions of $\mathrm{AgNO}_{3}$ and $\mathrm{KI}$. For a solution containing $1 \times 10^{-5} \mathrm{Ci}$ ${ }^{131} \mathrm{I} / 1$ iter $\left(6.2 \times 10^{-13} \underline{\mathrm{M} \mathrm{I}} \mathrm{I}^{-}\right),>95 \%$ of the radioactive iodide could be collected on the sulfonate sorbent when $1 \mathrm{~N} \mathrm{H}_{2} \mathrm{SO}_{4}$ and $5 \%$ sodium hexametaphosphate were added to the feed solutions to allow for selective sorption of only the radioiodine. Although this appears to be a promising adsorbent, more study is needed to elucidate the hydrodynamic properties and firmly establish the relative contributions of both isotopic exchange and ion exchange to the total binding mechanism. Swanson ${ }^{146}$ has also studied the removal of iodine species (both as $\mathrm{I}_{2}$ and $\mathrm{I}^{-}$) from dilute $\mathrm{HNO}_{3}$ with manganese dioxide $\left(\mathrm{MnO}_{2}\right)$-impregnated porous materials. Results were promising, but more study is needed concerning the selection of substrate material for optimization of $\mathrm{MnO}_{2}$ impregnation and improvement in DFs for high feed rates (DFs were near 100 on1y for flows less than one column volume per hr).

Large-scale operations for removal of iodine species from aqueous streams with anion exchange resins. Very early in the operation of power reactors, ion exchange resins were introduced to remove fission products from circulating coolant streams. The cleanup and filtering operations for purification of liquid streams in Boiling Water Reactor (BWR) and Pressurized Water Reactor (PWR) power plants have many similarities. Most of the differences arise because there are more circulating chemicals in the primary and secondary coolants of the PWR.

One of the early studies ${ }^{147}$ to determine the possibility of utilizing mixed anion and cation exchange beds to both control $\mathrm{pH}$ and remove fission products in sidestream coolant purification systems was 
in the NRX reactor at the Chalk River Nuclear Facility, Ontario. For in-pile loop tests at Chalk River, a column $2.54 \mathrm{~cm}$ ID and $91 \mathrm{~cm}$ long with a bed volume of $465 \mathrm{~cm}^{3}$, was operated at a superficial velocity of $0.71 \mathrm{~m} / \mathrm{min}$. The resin was $223 \mathrm{dry} \mathrm{g}$ of mixed bed, with anion exchanger IRA-400 in the hydroxyl form and IRA-120 in the lithium form. For ${ }^{131_{I}}$ and ${ }^{133} \mathrm{I}$, a $\mathrm{DF}$ of $10^{4}$ was obtained after 46 days of operation with very dilute iodide feeds. Mixed beds of the IRA-400 and IRA-120, in a $1 / 1$ equivalent ratio, were suggested for effectively controlling $\mathrm{pH}$ and radionuclides in PWR coolant streams.

Anion exchange resins in combination with charcoal beds were also tested to determine the feasibility of treating low-level radioactive liquid streams to recycle the purified water for reuse at nuclear installations. ${ }^{148}$ Iodine was specifically removed in two stages of the micropilot plant: one stage consisted of a 750-m1 bed of the strongbase anion exchange resin Dowex 1-X8 (20 to 50 mesh), and the second stage consisted of a 1200-ml bed of granular activated charcoal. For a flow rate of $150 \mathrm{ml} / \mathrm{min}$ and a feed concentration of $1 \times 10^{-10} \mathrm{~g}^{131_{\mathrm{I}^{-}}}$/ 1iter, DFs $\geq 10^{3}$ were obtained for radioactive iodine. Fletcher ${ }^{149}$ conducted a comprehensive study to determine mass transfer coefficients and equilibrium constants for ion exchange sorption of radionuclides (such as cesium and iodine) contained in aqueous coolants and liquid wastes from such nuclear installations as the Shippingport Atomic Power Station, Apollo, Pennsylvania. This paper is an excellent reference for those interested in theoretical analysis of ion exchange. Experimentally, the $\mathrm{DF}$ for ${ }^{131} \mathrm{I}^{-}$was determined at a flow rate of $0.114 \mathrm{~m} / \mathrm{min}$ through the anion exchanger $\mathrm{XE}-78$ (20 to 30 mesh) packed in a $1.75-\mathrm{cm}-\mathrm{ID}$ column. 
Resin properties were 20 to 30 mesh, with exchange capacities of 4.0 meq/dry $\mathrm{g}$ and $1.07 \mathrm{meq} /$ wet $\mathrm{cm}^{3}$. The resin was converted to the borate form and the feed contained $10^{-10} \underline{\mathrm{M} \mathrm{Na}}{ }^{131} \mathrm{I}$. The variation of $\mathrm{DF}$ and mass transfer rate with concentration of $\mathrm{KOH}$ indicated both competition of the $\mathrm{OH}^{-}$with $\mathrm{I}^{-}$for exchange sites and an effect of solution total ionic strength on DF. The data concerning the effects of $\mathrm{pH}$ and borate concentration on the DF for iodide was limited, but for XE-78 in the 1.75-cm-ID bed with 1000-ppm boric acid (no alkali), a ${ }^{131}$ I DF of 14 was obtained for $28 \mathrm{hr}$ of operation. In studies of the purification demineralizer in the Saxton reactor, Weisman ${ }^{*}{ }^{150}$ observed a reduction in iodide DF from $10^{4}$ to $10^{2}$ when the anion exchanger was converted to the borate form from the hydroxyl form. Again, the reduction was attributed to competition between borate and $\mathrm{I}^{-}$for exchange sites.

Theoretical derivations useful for analysis of ion exchange processes. Drawing from several theoretical discussions of the ion exchange process, expressions were derived for both the steady state and transient ion exchange reaction for the cases of mono-monovalent exchange and monopolyvalent exchange. ${ }^{151}$ The basic assumptions were that (1) the process involved exchanging radionuclides in trace concentrations that undergo decay; and (2) mass transfer was controlled by transfer of ions through the liquid film around the resin particle. Because of the complexity of these derivations, the resultant expressions will not be summarized here. Another derivation involved the expression for the mass transfer coefficient for ion exchange of a radionuclide undergoing decay from a trace concentration in a liquid feed. Those

\footnotetext{
* The Saxton nuclear power facility was a closed-cycle PWR operated in an experimental program conducted jointly by the Westinghouse Atomic Power Division and the Saxton Nuclear Experimental Corporation, a subsidiary of General Public Utilities Corporation of Pittsburg, Penn.
} 
interested in the mechanism of ion exchange should consult these derivations because of their considerable value in providing guidelines for the acquisition, analysis, and presentation of experimental data for the packed-bed ion exchange process.

Lin $^{152}$ has also discussed the ion exchange mechanism in relation to the interpretation of operating data obtained from utilities for the removal of trace radionuclides from liquids in commercial nuclear power plants. Specific aspects of ion exchange were those affecting ionic selectivity, reversibility of ion exchange reactions, exchange capacity, swelling equilibrium, and degree of cross linking. Because the rate of exchange reaction is generally so high, the rate-controlling step in the overall process is normally diffusion, mass transfer in either the solution film (at low ionic concentration) or through the resin particle (at high ionic concentration). Expressions were presented that were useful for (1) evaluating the rate-controlling step, and (2) evaluating the instantaneous rate of the overall ion exchange process.

Some of the experimental studies describing iodine species removal from liquids with anion exchange resins are summarized in Table 16.

\subsubsection{Present applications}

The following summation of the status of the technology (to 1973) of ion exchange resin utilization for treatment of nuclear power plant coolants was taken from Lin's excellent review ${ }^{152}$ of 24 nuclear power plants in the United States. The primary coolant streams in PWR and BWR power plants contain levels of radioactivity that vary from $10^{-7}$ to 
Table 16. Removal of iodine species from liquids by treatment with anion exchange resins

\begin{tabular}{|c|c|c|c|c|c|c|c|}
\hline Ref. & $\begin{array}{l}\text { Resin } \\
\text { form }\end{array}$ & $\begin{array}{c}\text { Feed } \\
\text { composition }\end{array}$ & $\begin{array}{l}\text { Bed } \\
\text { size }\end{array}$ & $\begin{array}{l}\text { Retention } \\
\text { time }\end{array}$ & $\begin{array}{l}\text { Loading } \\
\text { capacity }\end{array}$ & $\mathrm{DF}$ & $\begin{array}{l}\text { Batch } \\
\text { distribution } \\
\text { ratio }\end{array}$ \\
\hline 137 & $\begin{array}{l}\text { Strongly basic } \\
\text { anion exchanger } \\
\text { AV-17 in about } \\
10 \text { different } \\
\text { anion forms. }\end{array}$ & $\begin{array}{l}\text { Aqueous iodine- } \\
\text { KI solutions } \\
0.005 \text { to } 0.05 \underline{\mathrm{M}}\end{array}$ & $\mathrm{NA}^{\mathrm{b}}$ & $\begin{array}{c}\text { Batch } \\
\text { equilibration }\end{array}$ & $\begin{array}{l}0.38-0.9 \mathrm{~g} \\
\text { iodine }\end{array}$ & $\mathrm{ND}^{\mathrm{C}}$ & ND \\
\hline 138 & $\begin{array}{l}\text { Diaion SAN-1, } \\
\text { Amberlite IRN-78, } \\
\text { resingel and } \\
\text { chloride form. }\end{array}$ & $\begin{array}{l}\text { Aqueous or acidic } \\
(0-12 \mathrm{M}) \mathrm{HCl} \text { with } \\
\text { tracer } \mathrm{Na}^{13} 1_{\mathrm{I}}\end{array}$ & NA & $\begin{array}{c}\text { Batch } \\
\text { equilibration }\end{array}$ & ND & ND & $10-100$ \\
\hline 139 & $\begin{array}{l}\text { Anion exchangers } \\
\text { Diaion PA-316, } \\
\text { Amberlite IRA-900, } \\
\text { resin porous } \\
\text { structure, } \\
\text { chloride form. }\end{array}$ & $\begin{array}{l}\text { Aqueous and acidic } \\
(0-1 \mathrm{M}) \mathrm{HCl} \text { with } \\
\text { Nal } 131 \overline{\mathrm{I}} \text { tracer }\end{array}$ & NA & $\begin{array}{c}\text { Batch } \\
\text { equilibration }\end{array}$ & ND & ND & $10^{2}-10^{3}$ \\
\hline 142 & $\begin{array}{l}\text { Anion exchanger } \\
\text { Dowex } 2 \times 8, \\
20-50 \text { mesh, } \\
\text { chloride and } \\
\text { citrate forms. }\end{array}$ & $\begin{array}{l}\text { Milk at } 10^{\circ} \mathrm{C} \text { and } \\
\text { pH } 5.3 \\
131 \text { I tracer }\end{array}$ & $\begin{array}{l}65 \mathrm{~cm} \mathrm{ID} \mathrm{x} \\
224 \mathrm{~cm}\end{array}$ & $8-16 \min$ & ND & 143 & NA \\
\hline \multirow[t]{2}{*}{143} & $\begin{array}{l}\text { Anion exchangers } \\
\text { Amberlite IRA-910, }\end{array}$ & $\begin{array}{l}1 \times 10^{-5} \mathrm{MI}^{-} \text {in } \\
0.05 \mathrm{MO}_{3}\end{array}$ & $0.9 \times 19 \mathrm{~cm}$ & $30 \mathrm{~min}$ & $<0.07 \mathrm{mg} \mathrm{I}^{-} / \mathrm{cm}^{3}$ & $>10$ & NA \\
\hline & $\begin{array}{l}\text { IRA-900, Amber1yst } \\
\text { A-26. }\end{array}$ & $\begin{array}{l}1 \times 10^{-5} \mathrm{M} \mathrm{I}^{-} \text {in } \\
0.01 \mathrm{NO}_{3}\end{array}$ & $0.9 \times 19 \mathrm{~cm}$ & $30 \mathrm{~min}$ & $<0.35 \mathrm{mg} \mathrm{I}^{-} / \mathrm{cm}^{3}$ & $>10$ & NA \\
\hline 148 & $\begin{array}{l}\text { Anion exchanger } \\
\text { Dowex } 1-\mathrm{X} 8 \text {, } \\
20 \text { to } 50 \text { mesh. }\end{array}$ & $\begin{array}{l}\text { Simulated low-level } \\
\text { radioactive aqueous } \\
\text { wastes }\end{array}$ & $750-\mathrm{ml}$ bed & $5 \mathrm{~min}$ & ND & $>10^{3}$ & $\mathrm{NA}$ \\
\hline
\end{tabular}

${ }^{a}$ For resin properties, see text or Table 15.

${ }^{\mathrm{N} A}$ - Not applicable.

$C_{\text {ND - Not determined. }}$ 
$1 \mu \mathrm{Ci} / \mathrm{ml}$; for ${ }^{131} \mathrm{I}, 3.8 \times 10^{-3} \mu \mathrm{Ci} / \mathrm{ml}$ (or $1 \times 10^{-13} \underline{\mathrm{M}}{ }^{131} \mathrm{I}_{2}$ ) in a representative BWR, and $10^{-5} \mu \mathrm{Ci} / \mathrm{ml}$ (or $1 \times 10^{-15} \mathrm{M}^{131} \mathrm{I}_{2}$ ) in a representative PWR. Performance data with reference to removal of a specific radionuclide from the coolant and liquid waste streams are not normally available for individual power plants. Most removal efficiency data are based on gross $(\beta+\gamma)$ radioactivity measurements that do not provide identification of individual radionuclides. However, some plants do determine radioiodine removal efficiency as a measure of the nominal function of the ion exchangers.

The resins used most frequently by nuclear power plants are strong acid cation exchangers (because most of the radionuclides are cations) and strong base anion exchangers. The resins are generally synthetic organic resins with a polystyrene backbone. In conventional operation, resins with a particle size range of 0.4 to $0.7 \mathrm{~mm}$ are packed into beds that are 0.60 to $2.4 \mathrm{~m}$ ( 2 to $8 \mathrm{ft}$ ) in diam, 0.91 to $1.8 \mathrm{~m}$ ( 3 to $6 \mathrm{ft}$ ) deep, and contain 0.85 to $6.0 \mathrm{~m}^{3}$ of resin. Large powdered resin units that function as both filters and demineralizers are often used in BWRs. Flow rates for various ion exchange systems are: (1) 1 to $50 \mathrm{gpm} / \mathrm{ft}^{2}$ of bed cross section ( 4 to $200 \mathrm{~cm} / \mathrm{min}$ ) for BWRs; and (2) 5 to $20 \mathrm{gpm} / \mathrm{ft}^{2}$ (20 to $80 \mathrm{~cm} / \mathrm{min}$ ) for PWRs. Feed stream temperatures are usually below $60^{\circ} \mathrm{C}$. Feed streams in BWRs are near neutral, but the $\mathrm{pH}$ in $\mathrm{PWR}$ may vary widely from 4 to 10.5 .

So that the high quality of water required in light-water-cooled power reactors can be maintained, "nuclear grade" ion exchange resins must be employed. These nuclear grade resins are superior to regular grade because (1) they contain much smaller quantities of leachable 
organic impurities, (2) they have a more uniform particle size, and (3) they have a higher degree of conversion to ionic form. The physical and chemical properties of these nuclear grade resins are listed in Table 17. The operational parameters affecting the removal efficiency of these resins are: (1) chemical and physical forms of contaminants in the feed, (2) temperature, (3) $\mathrm{pH}$, (4) flow rate, (5) design and dimension of beds, and (6) degree of resin regeneration.

The ion exchange arrangement most frequently used in treatment of primary and secondary coolants and waste liquids is the mixed-bed system, which consists of a stationary bed containing mixed anion and cation exchange resins. The iodide species are removed primarily by the anion exchange resins. Under normal conditions, the concentrations of radioiodine species in liquid streams at nuclear power plants are much less than parts per billion. For example, in the primary coolant of a BWR the radioiodine concentrations are in the ranges as specified: (1) ${ }^{131} \mathrm{I}, 1 \times 10^{-7}$ to $3 \times 10^{-2} \mu \mathrm{Ci} / \mathrm{m} 1$; (2) ${ }^{132} \mathrm{I}, 10^{-2}$ to $4 \times 10^{-1}$ $\mu \mathrm{Ci} / \mathrm{ml}$; (3) ${ }^{133} \mathrm{I}, 5 \times 10^{-5}$ to $10^{-3} \mu \mathrm{Ci} / \mathrm{ml}$; (4) ${ }^{134} \mathrm{I}, 4 \times 10^{-2}$ to $4 \times 10^{-1} \mu \mathrm{Ci} / \mathrm{ml}$; (5) ${ }^{135} \mathrm{I}, 1 \times 10^{-4}$ to $2 \times 10^{-1} \mu \mathrm{Ci} / \mathrm{ml}$. For the primary coolant in a PWR, the radioiodine concentrations are in the ranges: (1) ${ }^{131} \mathrm{I}, 10^{-5}$ to $10^{-4} \mathrm{\mu Ci} / \mathrm{m} 1$; (2) ${ }^{133} \mathrm{I}, 6 \times 10^{-4}$ to $3 \times 10^{-3} \mu \mathrm{Ci} / \mathrm{ml}$; (3) ${ }^{135} \mathrm{I}, 10^{-3}$ to $10^{-2} \mu \mathrm{Ci} / \mathrm{ml}$.

The DFs shown in Table 18 represent time-average values over the operating life of the resin beds. They were derived from water treatment experience, ion exchange fundamentals, laboratory data, and plant operating experience. They are considered to be attainable for treatment of aqueous solutions containing radioactivity less than $0.1 \mu \mathrm{Ci} / \mathrm{m} 1$, 
Table 17. Characteristics of typical anion exchange resins ( $\mathrm{OH}^{-}$form) used in treatment of liquids in nuclear power plants

\begin{tabular}{|c|c|c|c|c|c|c|c|}
\hline $\begin{array}{l}\text { Resin } \\
\text { type }\end{array}$ & $\begin{array}{l}\text { Functional } \\
\text { groups }\end{array}$ & $\begin{array}{l}\text { Typical } \\
\text { regenerant }\end{array}$ & $\begin{array}{l}\text { Regeneration } \\
\text { leve1 } \\
(\%)\end{array}$ & $\begin{array}{c}\text { Theoretical } \\
\text { capacity } \\
\text { (meq/m1 wet resin) }\end{array}$ & $\begin{array}{l}\mathrm{pH} \\
\text { range }\end{array}$ & Max & $\begin{array}{l}\text { operating } \\
\text { temp } \\
\left({ }^{\circ} \mathrm{C}\right)\end{array}$ \\
\hline $\begin{array}{l}\text { Strong } \\
\text { base, } \\
\text { Type } 1\end{array}$ & $\begin{array}{l}\text { Quaternary } \\
\text { ammonium, } \\
\text { Type } 1\end{array}$ & $4 \% \mathrm{NaOH}$ & 80 & $0.5-1.0$ & $1-14$ & & 60 \\
\hline $\begin{array}{l}\text { Strong } \\
\text { base, } \\
\text { Type } 2\end{array}$ & $\begin{array}{l}\text { Quaternary } \\
\text { ammonium, } \\
\text { Type } 2\end{array}$ & $4 \% \mathrm{NaOH}$ & 80 & $0.5-1.0$ & $1-14$ & & 38 \\
\hline $\begin{array}{l}\text { Weak } \\
\text { base }\end{array}$ & $\begin{array}{l}\text { Primary, } \\
\text { secondary, } \\
\text { and/or tertiary } \\
\text { amine }\end{array}$ & $4 \% \mathrm{NH}_{4} \mathrm{OH}$ & 95 & $1.5-2.5$ & $1-7$ & & 93 \\
\hline
\end{tabular}


Table 18. Decontamination factors for radioiodine species that can be attained with various ion exchange systems ${ }^{a}$

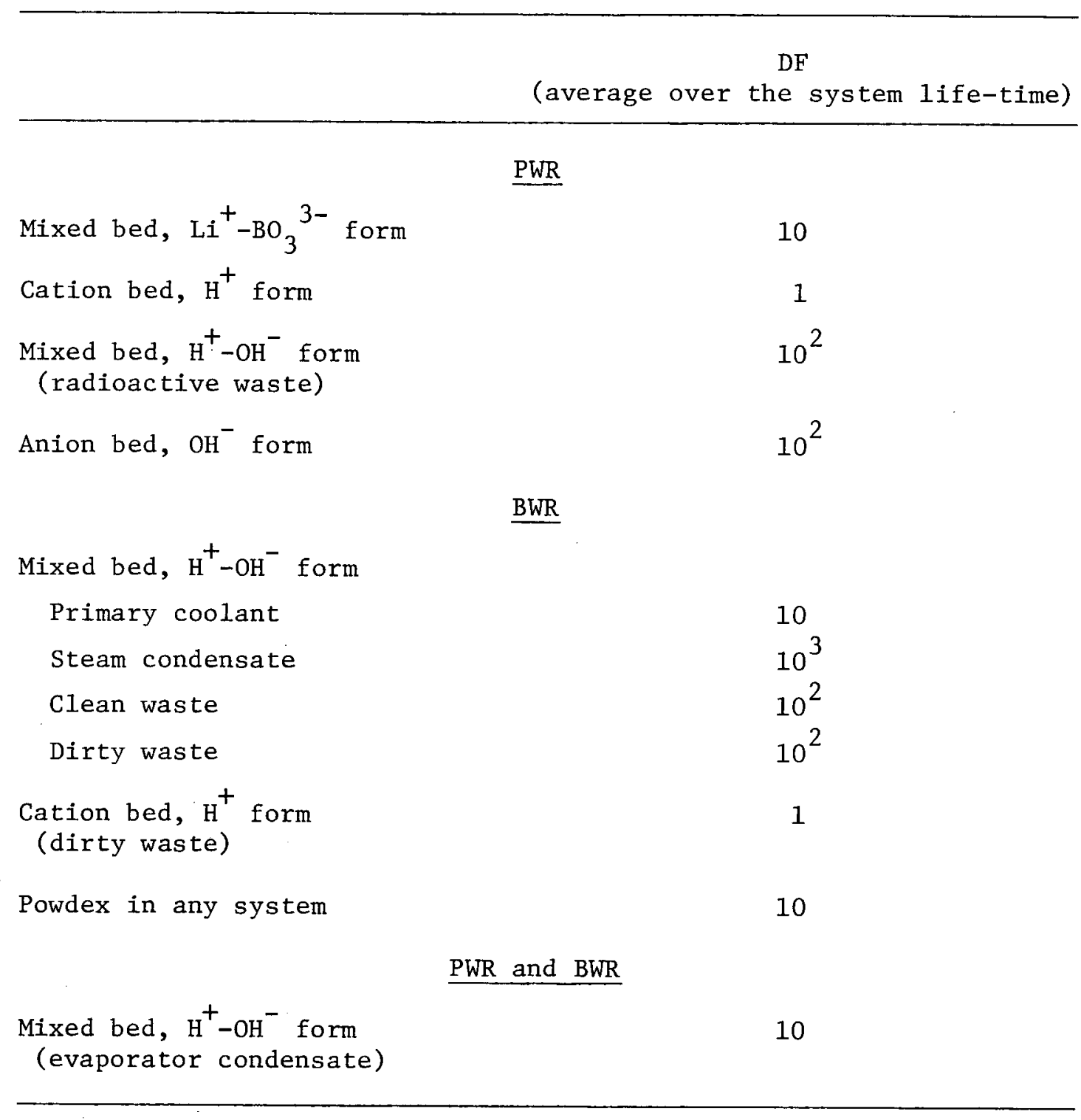

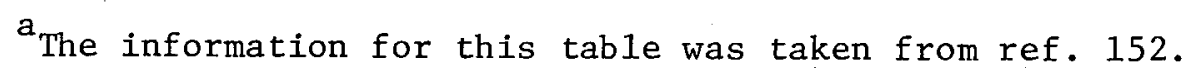


provided that (1) a sufficient amount of ion exchange resin is available, (2) the concentrations of dissolved and suspended solids are less than $1000 \mathrm{ppm}$, and (3) the systems are well-designed and effectively operated. Both the primary and secondary coolants in PWR plants contain additives, with hydrogen and hydrazine in the primary system for oxygen scavenging, enriched ${ }^{7} \mathrm{LiOH}$ for $\mathrm{pH}$ control to reduce corrosion, and $\mathrm{H}_{3} \mathrm{BO}_{3}$ for control of core reactivity. The secondary coolant may contain $\mathrm{Na}_{2} \mathrm{HPO}_{4}$ to render the water alkaline. The effect of these additives is to shorten the service life of resins for PWR coolant filtration, primarily by reducing the DFs and loading capacities of the resin beds. Because the liquid waste streams from LWR fuel reprocessing plants will also contain acid organic contaminants and perhaps other inorganics, some of the information gained in years of operating resins for cleanup of power plant coolants may be applicable to the treatment of fuel reprocessing liquid wastes.

Weisman and Bartnoff $\mathrm{f}^{150}$ had reported that the DF for radioiodine removal from a PWR coolant utilizing a KOH-form resin was decreased from $10^{4}$ to $10^{2}$ when a boric acid shim was added to the coolants. In another investigation to determine the effect of competitive anions on the iodide DF, Dickinson and Higgins ${ }^{153}$ conducted a study to determine the efficiency of intermediate-base and weak-base anion exchange resins for the removal of nuclides from boric acid shims in the presence of extraneous ions. Anion exchange resins were Duolite A-30R (an epoxy intermediate base), A-101D (styrene matrix, type 1 basicity), and DS-4155 (aliphatic weak base). Feed solutions for the anion exchangers contained $17,000-\mathrm{ppm} \mathrm{H}_{3} \mathrm{BO}_{3}, 2.54 \times 10^{4}-\mathrm{ppb}{ }^{131} \mathrm{I}$, 
and 100-ppm $\mathrm{Na}_{2} \mathrm{SO}_{3}$. The addition of $\mathrm{Na}_{2} \mathrm{SO}_{3}$ served to both maintain ionic iodide and provide extraneous ions. For sorption of ${ }^{131} \mathrm{I}^{-}$, only the intermediate-base resin A-30R was effective in removing iodide from a solution containing $\mathrm{Na}_{2} \mathrm{SO}_{3}$. The iodide $\mathrm{DF}$ for $\mathrm{A}-30 \mathrm{R}$ was $10^{4}$ with a loading of $0.017-\mathrm{Ci} /$ liter resin.

It has been discussed at several points in this review that for the composition and $\mathrm{pH}$ ranges which are predicted to exist in low-1eve1 radwaste liquid streams, it is highly probable that iodine will exist in both elemental and anionic forms. It thus follows that one logical approach to the treatment of such a stream would be to utilize series operation of two sorbent beds, chosen so that one has a high affinity for anionic species while the other has high affinity for elemental iodine. Alternately, a packed bed containing mixtures of sorbents having affinity for both elemental iodine and anionic iodine species could be utilized. Based on the sorbents discussed in this review, it is suggested that perhaps the most effective process for removal of iodine from low-level radwaste liquid streams would be operation of a bed of activated charcoal (highly impregnated with $\mathrm{K}^{+}$) in series with a bed of the appropriate strongly basic anion exchanger.

Shown in Figure 7 is a photograph of a bench-scale experimental facility employed at ORNL ${ }^{154}$ to test various types of impregnated charcoal, macroreticular resins, and anion exchangers for their ability to remove iodine from simulated low-level radioactive liquid wastes (with compositions similar to those discussed in Sect. 4.1 or those utilized by Moore and Howerton in their studies ${ }^{129-133}$ ). Iodine containing $10^{-4}$ to $10^{-5}$. $\mathrm{M}_{2}$ (with ${ }^{131} \mathrm{I}$ tracer) in aqueous or dilute 


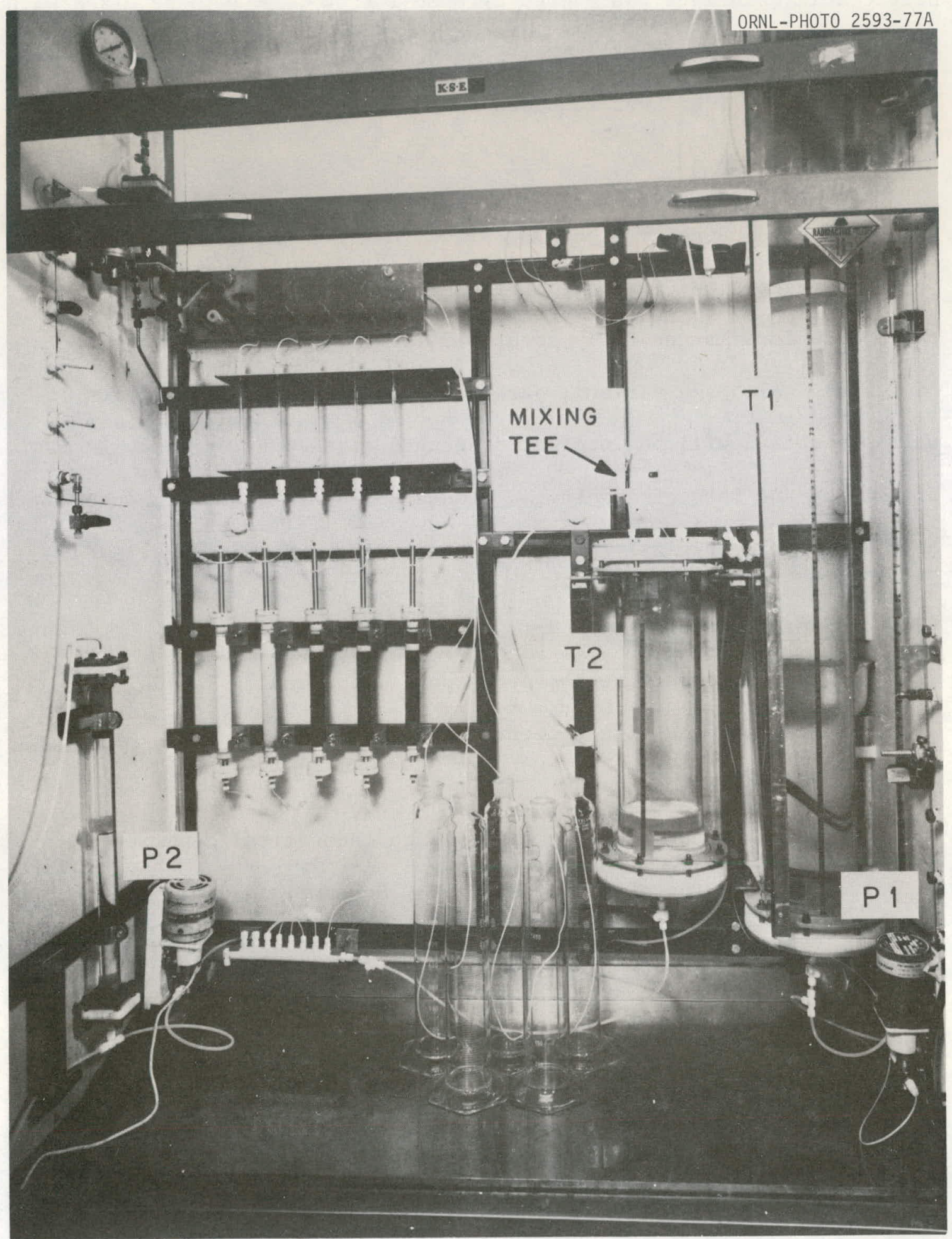

Fig. 7. Photograph of equipment used to screen candidate sorbents for removing iodine from aqueous solutions. 
nitric acid solutions was pumped by pump 1 from tank 1 to be mixed with distilled water in tank 2. From pressurized tank 2, the simulated lowlevel radwaste liquid was supplied to the various columns through a manifold.

\subsubsection{Process capacity}

The theoretical capacity of the anion exchangers for iodine in

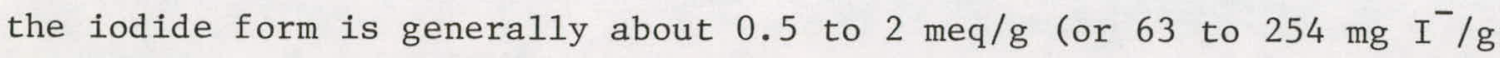
of resin). Although various operators establish different limits at which operation will be terminated because of decreasing removal efficiency and loss of loading, a standard discard limit would be when only $33 \%$ of the original theoretical capacity remains unused.

\subsubsection{Process advantages}

1. Anion exchange resins are capable of removing iodide from streams with concentrations ranging from $10^{-19} \underline{\mathrm{M}}$ to $10^{-5}$ M iodide.

2. Anion exchange resins have a high theoretical capacity for sorption of iodine species. However, loading capacity must always be considered to be a function of the DF delivered.

3. The loading capacity should not be seriously reduced by low-level organics in liquid radwaste streams.

4. Operation of anion exchangers in treating PWR and BWR coolants was successful to $60^{\circ} \mathrm{C}$. 


\subsubsection{Process disadvantages}

1. The capability of removing organic iodides from waste streams has not been shown.

2. The effect of competitive anions on loading capacity of anion exchanger for iodide must be established. The efficacy of the $\mathrm{NO}_{3}^{-}$form of various anion exchange resins would have to be estab1ished.

3. The effect of temperatures in excess of $60^{\circ} \mathrm{C}$ would have to be established.

4. The effect of $\mathrm{pH}$ and other ionic species on the disproportionation of iodine to elemental $\mathrm{I}_{2}$ and ionic species would need to be established for the particular liquid waste stream to be treated. The presence of some of the iodine as elemental $\mathrm{I}_{2}$ would probably reduce the overall DF to be achieved for iodine on an anion exchanger.

\section{SUMMARY}

A literature survey was conducted to provide information for the assessment of the various processes now available to remove iodine species from simulated LWR fuel reprocessing off-gases and low-level radwaste aqueous streams. The candidates for off-gas treatment included: two acid-scrub processes, Iodox and the mercuric nitrate-nitric acid scrubbing technique, and several processes based on solid sorbents such as silver zeolites; silver mordenite--lead mordenite sorbents in tandem; the proprietary Ag-KTB (AC-6120) material consisting of $\mathrm{AgNO}_{3}$-substituted silicic acid; and macroreticular 
resins. The candidates for low-level liquid waste treatment included: (1) activated charcoal, (2) macroreticular resins, and (3) anion exchange resins in general. These processes are summarized in the following sections.

\subsection{Methods for Removal of Iodine Species from Off-Gases}

The processes for iodine species removal from off-gases that have been most extensively investigated are the Iodox acid-scrubbing process (iodine scrubbed into hyperazeotropic nitric acid in bubble-cap columns),

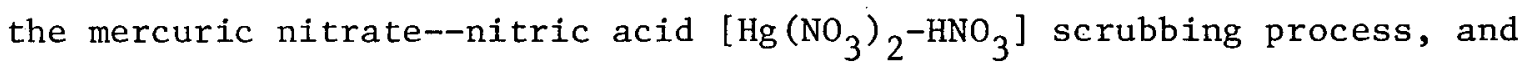
sorption on the solid sorbents (silver zeolite, silver mordenite--lead mordenite, and the Ag-KTB proprietary material). Specifically, these processes have been studied with the most accurately simulated fuel reprocessing off-gases, and in some cases have been utilized in actual pilot plant demonstration. The operating parameters that were considered to exert the most extensive effects on the iodine removal capabilities of the candidate processes are summarized in Table 19. Table 20 summarizes the experiments with each candidate process for those cases where the conditions most clearly simulated the treatment of LWR fuel reprocessing off-gases.

The Iodox process, which is excellent for off-gas treatment, should be applicable to both primary and secondary iodine removal, because acceptable DFs for $\mathrm{CH}_{3} \mathrm{I}$ of $10^{5}$ to $10^{6}$ can be obtained for feed concentrations of 200 to $0.02 \mathrm{mg} \mathrm{I} \mathrm{I}_{2} / \mathrm{m}^{3}$. The Iodox process is capable of processing feed gases containing high concentrations of $\mathrm{H}_{2} \mathrm{O}$ and $\mathrm{NO}_{\mathrm{x}}$ species at ambient temperatures and still deliver DFs $>10^{4}$ for $\mathrm{I}_{2}$ and $\mathrm{CH}_{3} \mathrm{I}$. 
Table 19. Comparison of systems for trapping iodine species from gaseous streams

\begin{tabular}{|c|c|c|c|c|c|c|}
\hline $\begin{array}{l}\text { Affecting } \\
\text { process } \\
\text { variable }\end{array}$ & Iodox & $\begin{array}{l}\text { Mercuric nitrate- } \\
\text { nitric acid }\end{array}$ & $\begin{array}{l}\text { Silver } \\
\text { zeolite }\end{array}$ & $\begin{array}{l}\text { Regenerable silver } \\
\text { mordenite-disposable } \\
\text { lead mordenite }\end{array}$ & $\begin{array}{l}\text { Macroreticular } \\
\text { resins }\end{array}$ & $\begin{array}{c}\text { Silver nitrate } \\
\text { impregnated silicic } \\
\text { acid, AC-6120, } \\
\text { West German material }\end{array}$ \\
\hline Water vapor & $\begin{array}{l}\text { Dilutes acid, } \\
\text { decreases process } \\
\text { DF and capacity }\end{array}$ & Minimal effect & $\begin{array}{l}\text { Reduces loading } \\
\text { capacity and } D F\end{array}$ & $\begin{array}{l}6 \% \mathrm{H}_{2} \mathrm{O} \text { and } 250^{\circ} \mathrm{C}^{\mathrm{a}} \\
\text { negligibly affected } \\
\text { capacity of } \mathrm{Ag}^{\circ} \mathrm{Z}\end{array}$ & $\begin{array}{l}\text { High relative humidity } \\
\text { decreases capacity } \\
\text { and } D F\end{array}$ & $\begin{array}{l}\text { Relative humidity } \\
>70 \% \text { affects } \\
\text { capacity and DF }\end{array}$ \\
\hline No & $\begin{array}{l}\text { Reacts to } \mathrm{NO}_{2} \text {, } \\
\text { reduces DFs on } \\
\text { lower trays }\end{array}$ & $\begin{array}{l}\text { Unknown, but possibly } \\
\text { similar to } \mathrm{NO}_{2}\end{array}$ & Unknown & $\begin{array}{l}2 \% \text { No increased } \\
\text { capacity of } \mathrm{Ag}^{\circ} \mathrm{Z}\end{array}$ & Unknown & Unknown \\
\hline $\mathrm{NO}_{2}$ & $\begin{array}{l}\text { Reduces DFs on } \\
\text { lower trays }\end{array}$ & $\begin{array}{l}\text { Eliminates iodate } \\
\text { formation, improves } \\
\text { process performance }\end{array}$ & $\begin{array}{l}2 \% \mathrm{NO}_{2} \text { and } 200^{\circ} \mathrm{C} \\
\text { greatly reduces } \\
\text { loading capacity } \\
\text { and } \mathrm{DF}\end{array}$ & $\begin{array}{l}\text { Negligible effect } \\
\text { of } 2 \% \mathrm{NO}_{2}\end{array}$ & $\begin{array}{l}\text { Unknown for gas but } \\
\text { resins are stable in } \\
\mathrm{HNO}_{3} \text { solutions }\end{array}$ & $\begin{array}{l}\text { Prevents oxidation of } \\
\text { Ag, enhances per- } \\
\text { formance }\end{array}$ \\
\hline $\mathrm{CO}_{2}$ & None & None & None & None & Unknown & $\begin{array}{l}\text { Unknown, probably } \\
\text { none }\end{array}$ \\
\hline Temperature & $\begin{array}{l}\text { Unknown, to be } \\
\text { determined }\end{array}$ & $\begin{array}{l}\text { Normal operation at } \\
40^{\circ} \mathrm{C} \text { for } \mathrm{Hg}\left(\mathrm{NO}_{3}\right)_{2} \\
\text { higher temp }\left(80^{\circ} \mathrm{C}\right) \\
\text { reduces capacity }\end{array}$ & $\begin{array}{l}\text { DF and loading } \\
\text { capacity for } \\
\mathrm{CH}_{3} \mathrm{I} \text { and } \mathrm{I}_{2} \text { vary. } \\
\text { directly and } \\
\text { inversely with } \\
\text { temperature } \\
\text { (respectively) }\end{array}$ & $\begin{array}{l}\text { No effect to } 250^{\circ} \mathrm{C} \\
\text { unless saturated } \\
\text { with } \mathrm{H}_{2}{ }^{\circ}\end{array}$ & Reduces capacity & $\begin{array}{l}\text { No effect to } 150^{\circ} \mathrm{C} \\
\text { unless } \mathrm{H}_{2} \text { o saturated }\end{array}$ \\
\hline $\begin{array}{l}\text { Organics and } \\
\text { other poisons }\end{array}$ & $\begin{array}{l}\text { May exclude aromatic } \\
\text { iodides: hexane } \\
\text { affects process } \\
\text { DF and capacity }\end{array}$ & $\begin{array}{l}\text { Aromatics drastically } \\
\text { reduce process DF and } \\
\text { capacity; other } \\
\text { aliphatics detract to } \\
\text { a lesser extent }\end{array}$ & $\begin{array}{l}\text { Not affected by } \\
\text { propane, hexane; } \\
\text { affected by dode- } \\
\text { cane, } \mathrm{H}_{2} \mathrm{~S}, \mathrm{SO}_{2}\end{array}$ & $\begin{array}{l}\text { Not determined; } \\
\text { probably same behavior } \\
\text { as } \mathrm{AgX} \mathrm{AgNO}_{3} \text {-impreg- } \\
\text { nated German material }\end{array}$ & $\begin{array}{l}\text { Organics in general } \\
\text { reduce capacity } \\
\text { (e.g., dodecane) }\end{array}$ & $\begin{array}{l}\text { Unaffected by a wide } \\
\text { range of cyclic and } \\
\text { aliphatic organics }\end{array}$ \\
\hline $\begin{array}{l}\text { Other } \\
\text { 1imitations }\end{array}$ & $\begin{array}{l}\text { Requires hyper- } \\
\text { azeotropic nitric } \\
\text { acid }\end{array}$ & Mercury disposal & $\begin{array}{l}\text { Cost, heat trans- } \\
\text { fer, solids } \\
\text { handling, affected } \\
\text { by prolonged ex- } \\
\text { posure to steam }\end{array}$ & $\begin{array}{l}\text { Heat transfer, solids } \\
\text { handling }\end{array}$ & $\begin{array}{l}\text { Heat transfer, solids } \\
\text { handling, poor hydro- } \\
\text { dynamic properties }\end{array}$ & $\begin{array}{l}\text { Cost, heat transfer, } \\
\text { solids hand } 1 \text { ing }\end{array}$ \\
\hline $\begin{array}{l}\text { Construction } \\
\text { material }\end{array}$ & Zircaloy ${ }^{b}$ & Stainless steel & Stainless steel & Stainless steel & Stainless steel & Stainless steel \\
\hline
\end{tabular}

${ }^{a}$ In general, sorption of $\mathrm{I}_{2}$ is less affected by process variables (such as humidity and organics) than is the sorption of $\mathrm{CH}_{3} \mathrm{I}$.

becent studies have indicated that other alloys may have to be considered for construction of Iodox. 
Table 20. Maximun decontamination factors obtained for iodine species removal from the feed-gas compositions

\begin{tabular}{|c|c|c|c|c|c|c|c|c|c|c|c|}
\hline Operation & $\begin{array}{r}\begin{array}{r}\text { Concen } \\
\text { iodin }\end{array} \\
\mathrm{I}_{2} \\
\left(\mathrm{mg} / \mathrm{m}^{3}\right) \\
\end{array}$ & $\begin{array}{l}\text { ration of } \\
\text { species. } \\
\begin{array}{c}\mathrm{CH}_{3} \mathrm{I} \\
\left(\mathrm{mg} / \mathrm{m}^{3}\right)\end{array} \\
\end{array}$ & $\begin{array}{c}\text { Gas feed } \\
\text { rate }\end{array}$ & $\begin{array}{c}\mathrm{No} \\
\text { conc } \mathrm{c}^{\mathrm{a}} \\
(\%)\end{array}$ & $\begin{array}{l}\mathrm{No}_{2} \\
\mathrm{conc} \\
(\%)\end{array}$ & $\begin{array}{c}\mathrm{H}_{2} \mathrm{O} \\
\text { conc }^{\mathrm{a}} \\
(\%) \\
\end{array}$ & $\begin{array}{l}\text { Column or } \\
\text { bed temp } \\
\left({ }^{\circ} \mathrm{C}\right)\end{array}$ & $\begin{array}{l}\text { Feed gas } \\
\text { remp } \\
\left({ }^{\circ} \mathrm{C}\right)\end{array}$ & $\begin{array}{l}\text { Loading } \\
\text { capacity }\end{array}$ & $\begin{array}{l}\text { Decontamination } \\
\text { factor }\end{array}$ & Effect of organics ${ }^{\mathrm{a}}$ \\
\hline \multirow{2}{*}{$\begin{array}{l}\text { Iodox } \\
10.2-c m-1 D, \\
8 \text { bubble-cap plates, } \\
15-c m \text { spacing }\end{array}$} & \multirow[t]{2}{*}{$\begin{array}{l}233 \\
(22 \mathrm{ppm})\end{array}$} & & $\begin{array}{l}96 \mathrm{slm} \\
(1.2 \mathrm{~m} / \mathrm{min})\end{array}$ & None & 2 & 2.4 & $\begin{array}{l}\text { Plate } 1-23 \\
\text { Plate } 6-27\end{array}$ & 221 & ND & $5 \times 10^{5}$ & ND \\
\hline & & $\begin{array}{l}264 \\
(46 \mathrm{ppm})\end{array}$ & $\begin{array}{l}98 \mathrm{slm} \\
(1.2 \mathrm{~m} / \mathrm{min})\end{array}$ & None & 7.6 & 1.9 & $\begin{array}{l}\text { Plate } 1-24 \\
\text { Plate } 6-27\end{array}$ & $\sim 21$ & ND & $3.2 \times 10^{5}$ & ND \\
\hline \multirow{2}{*}{$\begin{array}{l}\text { Mercuric nitrate-- } \\
\text { nitric acide } 2.54- \\
\text { cm-ID sinulated } \\
\text { bubble-cap column, } \\
8 \text { stages }\end{array}$} & \multirow[t]{2}{*}{$\begin{array}{l}600 \\
(57 \mathrm{ppm})\end{array}$} & & $\begin{array}{l}2.5 \mathrm{~s} 1 \mathrm{~m} \\
(5 \mathrm{~m} / \mathrm{min})\end{array}$ & None & $\mathrm{N}_{2} \mathrm{O}_{3} \odot 1$ & ND & 25 & 225 & ND & $5 \times 10^{4}$ & $\begin{array}{l}\text { No effect of octane, dodecane; xylene, } \\
\text { diethylbenzene reduced DFs to } 100\end{array}$ \\
\hline & & (7 $\mathrm{ppm})$ & $\begin{array}{l}2.5 \mathrm{sim} \\
(5 \mathrm{~m} / \mathrm{min})\end{array}$ & & $\mathrm{N}_{2} \mathrm{O}_{3}$ ( 0.4 & ND & 25 & 225 & ND & $8 \times 10^{4}$ & \\
\hline \multirow{4}{*}{$\begin{array}{l}\text { Silver zeolite } \mathrm{e}^{\mathrm{b}} \\
2.54 \times 5.08-\mathrm{cm} \text { beds }\end{array}$} & \multicolumn{2}{|l|}{500} & $60 \mathrm{~m} / \mathrm{min}$ & None & 2 & s & ND & 100 & $42 \mathrm{mg} \mathrm{I} / 2 / \mathrm{g}$ & $2 \times 10^{2}$ (breakthrough) & \multirow{4}{*}{$\begin{array}{l}\mathrm{I}_{2} \text { and } \mathrm{CH}_{3} \mathrm{I} \text { loading not affected by } \mathrm{O}_{2} \text {, } \\
\mathrm{CO}_{2} \text {, } \mathrm{H}_{2} \text {, propane, hexone, kerosene, but } \\
\mathrm{CH}_{3} \mathrm{I} \text { af fected by } \mathrm{H}_{2} \mathrm{~S} \text {, SO2 }\end{array}$} \\
\hline & \multirow[t]{3}{*}{29} & & $19 \mathrm{~m} / \mathrm{min}$ & None & None & 2.3 & 2200 & 200 & $6 \mathrm{mg} \mathrm{I} / \mathrm{g}$ & $2 \times 10^{5}$ & \\
\hline & & 2816 & $19 \mathrm{~m} / \mathrm{min}$ & None & None & 2.3 & 2200 & 200 & $74 \mathrm{mg} \mathrm{CH} 3 \mathrm{I} / \mathrm{g}$ & $>10^{4}$ & \\
\hline & & 2785 & $19 \mathrm{~m} / \mathrm{min}$ & None & None & 2.3 & $\sim 200$ & 200 & $178 \mathrm{mg} \mathrm{CH}_{3} \mathrm{I} / \mathrm{g}$ & $10^{2}$ & \\
\hline \multirow{2}{*}{$\begin{array}{l}\mathrm{Ag}-\mathrm{KTB}\left(\mathrm{AC}-6120 / \mathrm{H}_{1}\right)^{\mathrm{C}} \\
\mathrm{AgNO}_{3} \text { impregnated } \\
\text { amorphous } \mathrm{si1icic} \\
\text { acid, } 2.34 \times 10-\mathrm{cm} \\
\text { beds }\end{array}$} & \multirow[t]{2}{*}{$\begin{array}{l}4000 \\
(2380 \mathrm{ppm})\end{array}$} & & $15 \mathrm{~m} / \mathrm{min}$ & ND & $2-20$ & 4.2 & 150 & 150 & $=50 \mathrm{mg} I_{2} / \mathrm{g}$ & $>10^{4}$ & \multirow{2}{*}{$\begin{array}{l}\text { With the beneficial presence of } \mathrm{NO}_{2} \text {, removal } \\
\text { of } \mathrm{I}_{2} \text { was not affected by alkyl iodides, } \\
\text { secondary and tertiary alkyl iodides, ali- } \\
\text { cyclic and aromatic cyclic iodides }\end{array}$} \\
\hline & & $\begin{array}{l}100-150 \\
(17-26 \mathrm{ppm})\end{array}$ & $15 \mathrm{~m} / \mathrm{min}$ & ND & 10 & 4.2 & 150 & 150 & $5 \mathrm{mg} \mathrm{CH}_{3} \mathrm{I} / \mathrm{g}$ & $>10^{3}$ & \\
\hline \multirow{2}{*}{$\begin{array}{l}\text { Silver mordenite-- } \\
\text { lead mordenite } \\
\text { tandem beds. } \\
5 \times 15 \mathrm{~cm}\end{array}$} & \multirow[t]{2}{*}{$\begin{array}{l}1500 \\
(2163 \mathrm{ppm})\end{array}$} & & $15 \mathrm{~m} / \mathrm{min}$ & 2 & 2 & 5.6 & 150 & 150 & $\begin{array}{l}\text { Saturation zone, } \\
>150 \mathrm{mg} \mathrm{I} / 2 / \mathrm{g}\end{array}$ & $10^{3}$ to $10^{4}$ & ND \\
\hline & & d & d & d & d & d & d & d & $\begin{array}{l}\text { Overall average } \\
>120 \mathrm{mg} \mathrm{I}_{2} / \mathrm{g}\end{array}$ & d & $\mathrm{d}$ \\
\hline \multirow{3}{*}{$\begin{array}{l}\text { Macroreticular resins } \\
\text { Amber } 1 \text { ite XAD-4 } \\
0.5 \times 10-c \mathrm{~cm} \text { columns }\end{array}$} & 3000 & & $7.65 \mathrm{~m} / \mathrm{min} \mathrm{n}$ & None & None & 0 & 25 & 25 & $218 \mathrm{mg} \mathrm{I}_{2} / \mathrm{g}$ & $>10^{4}$ & \multirow{3}{*}{$\begin{array}{l}\text { Preloading XAD- } 12 \text { with } 20 \%(w / w) \text { of dodecane } \\
\text { reduced removal efficiency for } I_{2}\end{array}$} \\
\hline & 400 & & $12.2 \mathrm{~m} / \mathrm{min}$ & None & None & 1.8 & 25 & 25 & $>50 \mathrm{mg} \mathrm{I} \mathrm{I}_{2} / \mathrm{g}$ & $>10^{3}$ & \\
\hline & & $\begin{array}{l}1 \times 10^{3} \text { to } \\
4 \times 10^{3}\end{array}$ & $7.65 \mathrm{~m} / \mathrm{min}$ & None & None & 0 & 25 & 25 & $12 \mathrm{mg} \mathrm{CH}_{3} \mathrm{I} / \mathrm{g}$ & $>10^{2}$ & \\
\hline
\end{tabular}

$\mathrm{a}_{\mathrm{NN}}$, not determined.

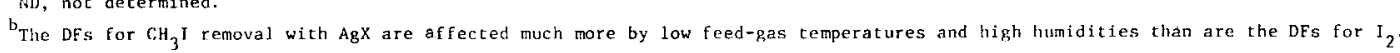

Available from Bayer in Jeverkusen, Federal Republic of Germany.

dNo data were taken for $\mathrm{CH}_{3} \mathrm{I}$. 
The combined effects of high relative humidity and high $\mathrm{NO}_{\mathrm{x}}$ concentration of feed gases at ambient temperature constitute one of the most severe tests of any system for removing iodine from off-gases. The major disadvantages of the Iodox process are probably the complexity of the system and the necessity of using costly, highly corrosive resistant construction materials to tolerate the severe effects of $>23 \underline{\mathrm{M}}$ hyperazeotropic nitric acid. The effect of organics such as dodecane, kerosene, and aromatic hydrocarbons on the Iodox process should be investigated further. There is evidence that aromatic iodides may escape the system.

For the $\mathrm{Hg}\left(\mathrm{NO}_{3}\right)_{2}-\mathrm{HNO}_{3}$ scrubbing process at ambient conditions, good DFs $\left(>10^{3}\right)$ were obtained for $\mathrm{CH}_{3} \mathrm{I}$ and $\mathrm{I}_{2}$ removal from off-gases containing high concentrations of $\mathrm{NO}_{x}$ (high concentration of $\mathrm{H}_{2} \mathrm{O}$ should not significantly affect the wet-scrub process). The presence of $\mathrm{NO}_{\mathrm{x}}$ 's actually benefits the scrubbing system by eliminating iodate formation. However, the DFs obtained for iodine in the $\mathrm{Hg}\left(\mathrm{NO}_{3}\right)_{2}-\mathrm{HNO}_{3}$ scrubbing process are severely reduced from $10^{4}$ to $10^{2}$ when aromatics are included in the feed gas. The DFs for the $\mathrm{Hg}\left(\mathrm{NO}_{3}\right)_{2}-\mathrm{HNO}_{3}$ system varied little for feed concentrations of 0.5 to $500 \mathrm{mg} / \mathrm{m}^{3}$.

Among the first solid sorbents that showed promise for off-gas treatment were the silver-exchanged zeolites $(\mathrm{AgX})$. Silver zeolites are very efficient for iodine species removal at high off-gas temperatures and are able to adsorb iodine to $500^{\circ} \mathrm{C}$ and retain iodine to $1000^{\circ} \mathrm{C}$. However, when off-gases are treated at ambient conditions, the efficacy of $\mathrm{AgX}$ for the organic iodides, as represented by $\mathrm{CH}_{3} \mathrm{I}$, is severely reduced by the presence of water vapor. For example, at $25^{\circ} \mathrm{C}$, the DFs for $\mathrm{I}_{2}$ and $\mathrm{CH}_{3} \mathrm{I}$ were $10^{4}$ for dry air with loading of $\sim 50 \mathrm{mg} \mathrm{I}_{2} / \mathrm{g}$ 
$\mathrm{AgX}$. However, the introduction of $\mathrm{H}_{2} \mathrm{O}$ to $90 \%$ relative humidity resulted in a severe reduction in the $\mathrm{DF}$ for $\mathrm{CH}_{3} \mathrm{I}$ to $\sim 20$. The $\mathrm{DF}$ for $\mathrm{I}_{2}$ is much less affected by $\mathrm{H}_{2} \mathrm{O}$ and can remain at $10^{4}$ with only a small. 1oss in loading capacity. To retain high trapping efficiencies for $\mathrm{CH}_{3} \mathrm{I}$ as well as $I_{2}$ in the presence of water vapor, it has been necessary to heat $\mathrm{AgX}$ beds and the incoming feed gas to as high as 100 to $200^{\circ} \mathrm{C}$, at which temperatures the effects of water vapor are negated (and the attraction of $\mathrm{CH}_{3} \mathrm{I}$ for $\mathrm{AgX}$ is apparently enhanced). In the absence of $\mathrm{NO}_{\mathrm{x}} \mathrm{s}, \mathrm{AgX}$ can be effectively utilized to achieve $\mathrm{DFs} \geq 10^{4}$ for removing $\mathrm{CH}_{3} \mathrm{I}$ and $\mathrm{I}_{2}$ from off-gases heated to $150^{\circ} \mathrm{C}$ and containing $70 \%$ relative humidity. However, only those zeolites which are acid resistant could be expected to withstand prolonged exposure to $\mathrm{NO}_{\mathrm{x}} \mathrm{s}$ in a humid atmosphere. Silver zeolites have been shown to be effective in reducing the iodine in offgases to $\leq 10^{-10} \mathrm{mg} / \mathrm{m}^{3}$.

Recent studies have shown that acid-resistant silver mordenites and

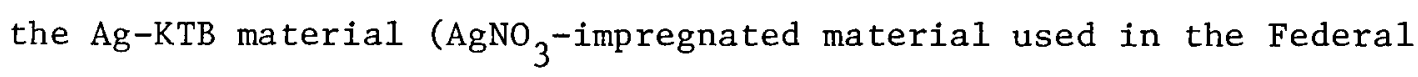
Republic of Germany for iodine removal from fuel reprocessing off-gases) are able to tolerate 4 to $5 \% \mathrm{H}_{2} \mathrm{O}$ and 2 to $10 \% \mathrm{NO}_{\mathrm{x}}$ when the beds are operated in the 100 to $150^{\circ} \mathrm{C}$ range, while still delivering very acceptable DFs of $10^{4}$. Both sorbents should be capable of processing feed containing $\mathrm{I}_{2}$ varying from 100 to $10^{-3} \mathrm{ppm}$. The Ag-KTB material is actually beneficially affected by $\mathrm{NO}_{2}$, which apparently prevents oxidation of the Ag. The silver mordenite--lead mordenite tandem system $\left(\mathrm{Ag}^{\circ} \mathrm{Z}-\mathrm{Pb}^{\circ} \mathrm{Z}\right)$ compares favorably in all respects to the Ag-KTB and may offer the advantage of a reduction in cost because the $\mathrm{Ag}^{\circ} \mathrm{Z}$ bed can be recycled. However, the ultimate application of the $\mathrm{Ag}^{\circ} \mathrm{Z}-\mathrm{Pb}^{\circ} \mathrm{Z}$ system will be 
dependent on determining if it can retain $\mathrm{CH}_{3} \mathrm{I}$ removal efficiency for high-humidity feed gases. A wide range of organics that might be found in actual off-gas should also be studied to determine how they might affect the DF and loading capacity of both $\mathrm{I}_{2}$ and $\mathrm{CH}_{3} \mathrm{I}$ in the $\mathrm{Ag}^{\circ} \mathrm{Z}-\mathrm{Pb}^{\circ} \mathrm{Z}$ system. The effects of organics on DF and loading capacity have been wel1-defined for $\mathrm{Ag}-\mathrm{KTB}$.

There have been insufficient studies to allow for the full characterization of the capability of macroreticular resins to remove iodine species from off-gases. Based on the initial studies, the macroreticular resins appear more promising for operation at ambient conditions than for temperatures $\geq 100^{\circ} \mathrm{C}$. For $\mathrm{CH}_{3} \mathrm{I}$ feed concentrations of $1 \times 10^{3}$ to $4 \times 10^{3} \mathrm{mg} / \mathrm{m}^{3}$, the best removal efficiency was obtained with Amberlite $\mathrm{XAD}-12$. The loading capacity for a flow rate of $7.65 \mathrm{~m} / \mathrm{min}$ at $50^{\circ} \mathrm{C}$ was $84-\mathrm{mg} \mathrm{CH}_{3} \mathrm{I} / \mathrm{g}$ with a maintained $\mathrm{DF}$ of $10^{4}$. However, the feed was bone-dry air; it is therefore likely that with the introduction of $\mathrm{H}_{2} \mathrm{O}$, the loading capacity and DF would decrease considerably (e.g., the $\mathrm{I}_{2}$ loading for $\mathrm{XAD}-12$ was $1390-\mathrm{mg} \mathrm{I}_{2} / \mathrm{g}$ at $25^{\circ} \mathrm{C}$ and $0 \%$ relative humidity, but $60-\mathrm{mg} \mathrm{I}_{2} / \mathrm{g}$ resin at $25^{\circ} \mathrm{C}$ and $60 \%$ relative humidity). Generally, the loading capacity and $\mathrm{DF}$ for $\mathrm{CH}_{3} \mathrm{I}$ of $\mathrm{XAD}-12$ at $25^{\circ} \mathrm{C}$ and $\sim 0 \%$ relative humidity were comparable to the best data obtained for silver zeolites or mordenites under similar operating conditions. However, experiments should have been conducted to determine the interrelated effect of high humidity and high $\mathrm{NO}_{x}$ content on the DFs that could be obtained for $\mathrm{CH}_{3} \mathrm{I}$ removal at ambient conditions. No studies have been made with the resin for dilute feeds $\left(<1.0 \mathrm{mg} / \mathrm{m}^{3}\right)$. 
Due in part to the 1ack of sufficient data for the macroreticular resins, the silver mordenite--lead mordenite system and the Ag-KTB sorbent must be considered more promising than the macroreticular resin because: (1) those sorbents retain their performance for humid feeds if the beds and feed are heated, and (2) those sorbents are less likely to be fouled by organics than are the macroreticular resins. All three systems (silver mordenite--lead mordenite, Ag-KTB material, and macroreticular resins) would appear to have comparable tolerance for high-NO${ }_{\mathrm{x}}$ concentrations.

Activated charcoal was not considered as a candidate for removing iodine species from nuclear fuel reprocessing off-gases because: (1) it is deleteriously affected by nitrogen oxides (with possible generation of explosive compounds); (2) it desorbs iodine readily at high temperatures; (3) it has a low ignition temperature; (4) it is unsatisfactory as a solid for long-term burial.

Based on the ranges of superficial velocity presented in Table 20 for the sizes of contactors indicated, the acidic solution-scrub processes [Iodox and $\mathrm{Hg}\left(\mathrm{NO}_{3}\right)_{2}-\mathrm{HNO}_{3}$ ] would apparently require considerably larger equipment than would the solid sorbents for treating the same full-scale volumes of off-gases for iodine removal.

In summary, the Iodox system has produced iodine removal DFs that are as good or better than those obtained by any other process used for off-gas treatment. However, there are legitimate concerns about the operational complexity of Iodox, the difficulty in maintaining plumbing integrity in view of the corrosive scrubbing solution employed, and the full-scale process size and the capital costs. These concerns may lead 
to adoption of either the Ag-KTB sorbent system or the silver mordenite-lead mordenite regenerable system for iodine species removal from fuel reprocessing off-gases. All necessary experiments and complete cost analyses have not been conducted, however, so that a carefully considered selection cannot yet be made.

\subsection{Methods for Removing Iodine Species from Dilute Aqueous Solutions}

A summary of the principal process parameters and their major effects on the candidate processes for removing iodine species from low-activitylevel aqueous and acidic solutions is shown in Table 21 . Activated charcoal is a possible candidate for this process, because the operating conditions would be in a wetted phase well-below the ignition temperature. There would still be questions, however, about the ultimate disposal of charcoal that had been in prolonged contact with nitrates. In studies of the candidate processes to remove iodine species from liquids, activated charcoal, macroreticular resins, or silver zeolite, Moore ${ }^{132}$ has shown that activated coconut charcoal was the most efficient for removing iodine from a $1 \times 10^{-6} \underline{\mathrm{M}} \mathrm{I}_{2}$ aqueous feed solution. The DFs for $\mathrm{I}_{2}$ and the flow rates for each of the three sorbents in $0.4-$ by $10-\mathrm{cm}$ columns were: (1) $10^{4}$ at $0.15 \mathrm{~m} / \mathrm{min}$, activated charcoal; (2) 142 at $0.08 \mathrm{~m} / \mathrm{min}$, Amberlite XAD-12; and (3) 33 at $0.016 \mathrm{~m} / \mathrm{min}$, silver zeolite. Charcoal has been used to achieve DFs of $10^{3}$ for feeds as low as $10^{-13} \underline{M ~ I}_{2}$. Details of specific studies with the various sorbents are shown in Table 22. 
Table 21. Comparison of systems for removing iodine species from low levels in liquid streams

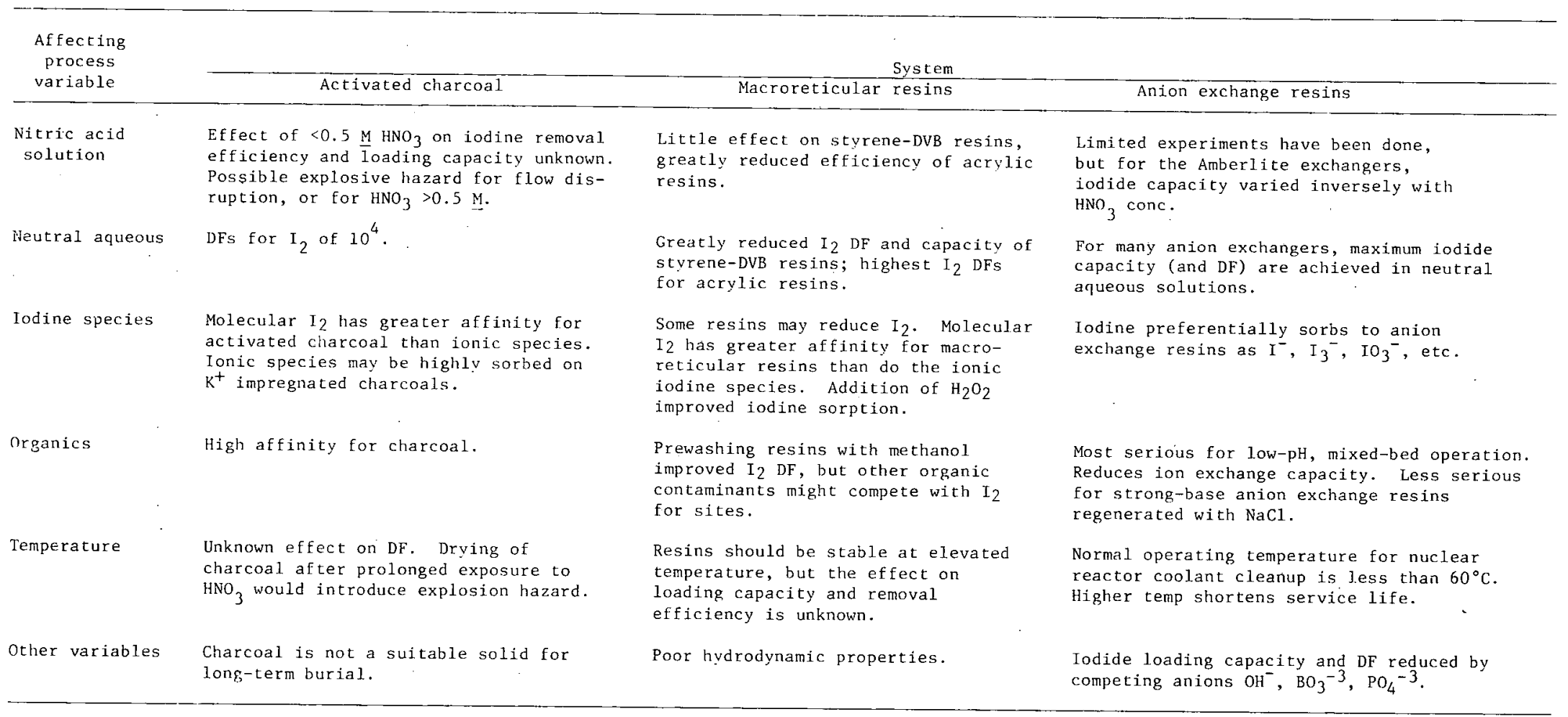


Table 22. Maximum decontamination factors obtained for iodine species removal from aqueous and dilute acidic streams

\begin{tabular}{|c|c|c|c|c|c|c|c|c|}
\hline Operation & $\begin{array}{l}\text { Concentration } \\
\text { of iodine } \\
\text { species }\end{array}$ & $\begin{array}{l}\text { Flow } \\
\text { rate } \\
(\mathrm{m} / \mathrm{min})\end{array}$ & $\begin{array}{l}\text { Aqueous } \\
\text { solution }\end{array}$ & $\begin{array}{l}\text { Acidic } \\
\text { solution }\end{array}$ & $\begin{array}{l}\text { Other } \\
\text { components }\end{array}$ & $\begin{array}{l}\text { Column } \\
\text { temp } \\
\left({ }^{\circ} \mathrm{C}\right)\end{array}$ & $\begin{array}{l}\text { Loading } \\
\text { capacity }\end{array}$ & DF \\
\hline $\begin{array}{l}\text { Activated charcoal, } \\
0.4 \times 10-\mathrm{cm} \text { column }\end{array}$ & $1 \times 10^{-6} \underline{\mathrm{M}} \mathrm{I}_{2}$ & 0.15 & Yes & $\mathrm{NA}^{\mathrm{a}}$. & None & 21 & $\mathrm{ND}^{\mathrm{b}}$ & $10^{4}$ \\
\hline $\begin{array}{l}\text { Macroreticular resins: } \\
\text { Amberlite XAD-12, } \\
0.4 \times 15-\mathrm{cm} \text { column } \\
\text { XAD-4, } 0.4 \times 25 \mathrm{~cm} \\
\text { XAD-4, } 0.9 \times 19 \mathrm{~cm}\end{array}$ & $\begin{array}{lllll}5 & \times 10^{-4} & M & I_{2} \\
1 & \times & 10^{-6} & \frac{M}{M} & I_{2} \\
5 & \times & 10^{-4} & \frac{M}{M} & I_{2} \\
5 & \times & 10^{-4} & M & I_{2} \\
1 & \times & 10^{-5} & \bar{M} & I_{2}\end{array}$ & $\begin{array}{l}0.04 \\
0.017 \\
0.04 \\
0.04 \\
0.006\end{array}$ & $\begin{array}{l}\text { Yes } \\
\text { Yes } \\
\text { NA } \\
\text { NA } \\
\text { NA }\end{array}$ & $\begin{array}{c}\text { NA } \\
\text { NA } \\
0.5 \mathrm{M} \text { nitric acid } \\
3.0 \frac{\mathrm{M}}{\mathrm{M}} \text { nitric acid } \\
0.05^{\mathrm{M}} \text { nitric acid }\end{array}$ & $\begin{array}{l}\text { None } \\
\text { None } \\
\text { None } \\
\text { None } \\
0.3 \mathrm{M}_{2} \mathrm{O}_{2}\end{array}$ & $\begin{array}{l}21 \\
21 \\
21 \\
21 \\
20\end{array}$ & 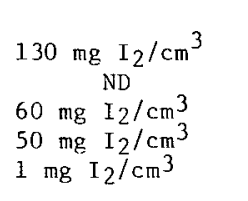 & $\begin{array}{r}160 \\
50 \\
14-25 \\
\sim 100 \\
>10^{2}\end{array}$ \\
\hline $\begin{array}{l}\text { Anion exchange resins: } \\
\text { Amberlite IRA-910 } \\
\text { and IRA-900, } \\
\text { Amberlyst } A-26 \text {, } \\
0.9 \times 19 \mathrm{~cm}\end{array}$ & $\begin{array}{lll}1 \times 10^{-5} & \mathrm{M}^{-} \\
\mathrm{I} \times 10^{-5} & \frac{\mathrm{M}}{\mathrm{M}} \mathrm{I}^{-}\end{array}$ & $\begin{array}{l}0.006 \\
0.006\end{array}$ & $\begin{array}{l}\mathrm{NA} \\
\mathrm{NA}\end{array}$ & $\begin{array}{l}0.05 \frac{M}{M} \text { nitrate } \\
0.01\end{array}$ & $\begin{array}{l}\text { None } \\
\text { None }\end{array}$ & $\begin{array}{l}20 \\
20\end{array}$ & $\begin{array}{l}<0.07 \mathrm{mg} \mathrm{I} \mathrm{I}^{-} / \mathrm{cm}^{3} \\
<0.35 \mathrm{mg} \mathrm{I}-/ \mathrm{cm}^{3}\end{array}$ & $\begin{array}{l}>10 \\
>10\end{array}$ \\
\hline $\begin{array}{l}\text { Anion exchange resins, } \\
0.6 \text { to } 2.4 \mathrm{~m} \text { ID } \mathrm{x} \\
0.9 \text { to } 1.8-\mathrm{m} \text { deep } \\
\text { beds. PWR and BWR } \\
\text { coolant cleanup }\end{array}$ & $\begin{array}{l}10^{-19} \\
10^{-11} \text { to } \\
\text { M }\end{array}{ }^{131} \mathrm{I}^{-}$ & 0.04 to 2.0 & & $\begin{array}{l}\text { Aqueous for BWR: } \\
\mathrm{pH} \text { varies from } 4 \\
\text { to } 10.0 \text {, may con- } \\
\text { tain from } 0.01 \text { to } \\
0.05 \mathrm{M}_{3} \mathrm{BO}_{3} \text { in } \\
\text { PWRs. }\end{array}$ & $\begin{array}{l}\text { No additives for } \mathrm{BWR} \text {; } \\
\text { PWR coolant contains } \\
\text { hydrazine, hydrogen, } \\
7 \mathrm{LiOH}_{3} \mathrm{H}_{3} \mathrm{BO}_{3} \text {, Na } \mathrm{HPO}_{4} \text {; } \\
\mathrm{BO}_{3}-\text { reduces life and } \\
\text { capacity of resins; } \\
\text { other trace radio- } \\
\text { nuclides also present. }\end{array}$ & $<60$ & $\begin{array}{l}63 \text { to } 254 \mathrm{mg} \\
\mathrm{I} / \mathrm{g} \text { dry resin }\end{array}$ & $\sim 10^{2}$ \\
\hline
\end{tabular}

${ }^{a} \mathrm{NA}$, not applicable.

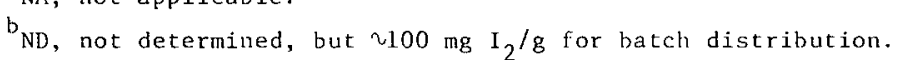


The manner in which the iodine disproportionates is very critical for all the candidate processes used to treat iodine bearing solution. Because of the nature of their chemical structure, the macroreticular resins have the greatest affinity for molecular compounds, so they would most probably have a greater capacity for organic iodides and molecular iodine than for ionic iodine. Swanson ${ }^{136}$ has reported that the loading capacity of resins for $I_{2}$ from very dilute acidic solutions can be enhanced by the addition of oxidants such as $\mathrm{H}_{2} \mathrm{O}_{2}$ and ferric ion to counteract reductant effects on $I_{2}$ resulting from the acidic solution interactions with the resin structure. The capacity of activated charcoal for iodine as molecular $\mathrm{I}_{2}$ or in ionic form is apparently strongly dependent on the degree of hydrolysis of iodine in dilute solutions; it also depends on the metal content (primarily as $\mathrm{K}^{+}$) of the native and/or impregnated charcoals. In general, charcoal and macroreticular resins have shown comparable loading capacities for $I_{2}$ in the 50 to $100 \mathrm{mg} / \mathrm{g}$ sorbent range. However, loading capacities are very dependent on flow conditions and thus on the level of DF that is to be established and maintained (capacity increases as DF is allowed to decrease). Of the two sorbents, charcoal and macroreticular resins, charcoal would appear to be preferable in terms of DF and loading capacity delivered for a given flow rate, and also for the capability of maintaining high DFs as flow rates increase (thus effectively reducing contactor size relative to that required for macroreticular resins). A valid question may concern storage capabilities of both kinds of sorbents, particularly as related to their ability to retain sorbed iodine at higher temperatures. 
The most promising method for iodine species removal from aqueous and dilute acidic nitrate liquors may well be (from a mechanistic standpoint) the utilization of anion exchange resins. These resins would be employed after the waste solution had been treated to ensure that all the iodine was in the ionic form. Anion exchange resins are widely used in the nuclear power industry to remove radionuclides from reactor coolants, condensates, and dischargeable plant liquor wastes. They are capable of treating waste streams with iodine concentrations ranging from $10^{-5}$ to $10^{-19} \underline{\mathrm{M}} \mathrm{I}^{-}$, while delivering DFs of 100 at temperatures to $60^{\circ} \mathrm{C}$. The $\mathrm{DF}$ for $\mathrm{I}^{-}$on these resins can be deleteriously affected by other anions (such as $\mathrm{BO}_{3}^{-3}$ and $\mathrm{PO}_{4}^{-3}$ ), and also by prolonged exposure to organic-laden solutions. However, a distinct argument for the anion exchanger beds is the long and favorable operating experience gained with their use in the nuclear power industry in a great variety of flow conditions.

Because of the chemical composition and $\mathrm{pH}$ ranges which are expected for low-level radwaste liquid streams, it is highly probable that iodine will exist in both elemental and anionic forms. Thus the best approach for removal of total iodine may ultimately be to utilize a bed of mixed sorbents having strong affinity and high loading capacity for both elemental and anionic iodine. 
THIS PAGE

WAS INTENTIONALLY

LEFT BLANK 
APPENDIX A: CONCENTRATIONS OF IODINE SPECIES EXPECTED IN LWR

FUEL REPROCESSING DISSOLVER OFF-GASES AND LOW-LEVEL LIQUID

WASTE STREAMS

\section{A-1. Dissolver off-Gas Concentration}

In this literature survey, several different estimates of the concentration of $\mathrm{I}_{2}, \mathrm{I}^{-}$, and $\mathrm{CH}_{3} \mathrm{I}$ to be expected in dissolver off-gas were encountered. Although there was certainly some disagreement in the estimates of different investigations, the overall comparison of the various estimated levels was fairly good. The estimates of the different experiments are shown below:

Study $\quad$ Ref.

D. Crouse et al.

D. Crouse et al.

W. E. Davis

B. A. Hannaford

J. G. Wilhelm

L. P. Murphy et al.

4

$16-20$

97

105

$$
\begin{aligned}
& \begin{array}{c}
\text { Head-end dissolver } \\
\text { off-gas }
\end{array} \\
& \hline
\end{aligned}
$$

$45 \mathrm{ppm} \mathrm{I}$,

$14 \mathrm{ppm} \mathrm{CH}_{3} \mathrm{I}$
Secondary iodine removal 
Conversion of iodine species concentration can be made utilizing the following factors (based on $1 \mathrm{~m}^{3}$ at $21^{\circ} \mathrm{C}$ and 1 atm):

$$
\begin{aligned}
& \frac{1 \mu \mathrm{g} \mathrm{CH}_{3} \mathrm{I}}{\mathrm{m}^{3}}=0.17 \mathrm{ppb}, \\
& \frac{1 \mu \mathrm{g} \mathrm{I}}{\mathrm{m}^{3}}=0.19 \mathrm{ppb}, \\
& \frac{1 \mu \mathrm{g} \mathrm{I}}{\mathrm{m}^{3}}=0.095 \mathrm{ppb} .
\end{aligned}
$$


1. W. Davis, Jr., A Model of Iodine Transport and Reaction Kinetics in a Nuclear Fue1 Reprocessing Plant, ORNL/NUREG-16 (August 1977).

2. "Environmental Radiation Protection Standards for Nuclear Power Operations," Environmental Protection Agency [40 CFR Part 190 Subchapter F - Radiation Protection Programs] [FRL 695-6], Fed. Regist. 42, 9 (1977).

3. B. C. Finney, R. E. Blanco, R. C. Dahlman, F. G. Kitts, and J. P. Witherspoon, Correlation of Radioactive Waste Treatment Costs and the Environmental Impact of Waste Effluents in the Nuclear Fuel Cycle for Use in Establishing "as low as practicable" Guides - Nuclear Fuel Reprocessing, ORNL/TM-4901 (May 1975).

4. W. Davis, Jr., R. E. Blanco, B. C. Finney, G. S. Hill, R. E. Moore, and J. P. Witherspoon, Correlation of Radioactive Waste Treatment Costs and the Environmental Impact of Waste Effluents in the Nuclear Fuel Cycle - Reprocessing of High-Temperature Gas-Cooled Reactor Fue1 Containing U-233 and Thorium, ORNL/NUREG/TM-4 (May 1976).

5. J. C. Mailen, personal communication, December 1976.

6. R. H. Rainey and J. C. Mailen, "Solubility of $\mathrm{HI}_{3} \mathrm{O}_{8}$ in Concentrated Nitric Acid," J. Chem. Eng. Data 19, 262 (1974).

7. J. C. Mailen and T. O. Tiffany, "The Reaction of Iodine with Concentrated Nitric Acid," J. Inorg. Nuc1. Chem. 37, 127 (1975).

8. J. C. Mailen, "Equilibrium in the Oxidation of Iodine by Hyperazeotropic Nitric Acid," J. Inorg. Nucl. Chem. 37, 1019 (1975).

9. J. C. Mailen, Use of Chemical Equilibrium Data to Calculate Iodox Column Operations, ORNL/TM-5077 (1975).

10. D. J. Crouse and W. B. Howerton, LMFBR Fuel Cycle Studies Progress Report for May, 1972, ORNL/TM-3888, p. 20 (1972).

11. J. C. Mailen and W. B. Howerton, Aqueous Fuel Reprocessing Quarterly Report for Period Ending March 31, 1974, ORNL/TM-4587, p. 56 (1974).

12. J. C. Mailen, W. C. Clark, and C. T. Thompson, Aqueous Fuel Reprocessing Quarterly Report for Period Ending Dec. 31, 1975, ORNL/ TM-4488, p. 31 (1975).

13. D. J. Crouse, J. M. Schmitt, and W. B. Howerton, LMFBR Fuel Cycle Studies Progress Report for March 1972, ORNL/TM-3807, p. 72 (1972). 
14. W. S. Groenier, An Engineering Evaluation of the Iodex Process: Removal of Iodine from Air Using a Nitric Acid Scrub in a Packed Column, ORNL/TM-4125 (August 1973).

15. W. S. Groenier and B. A. Hannaford, An Engineering Evaluation of the Iodox Process: Part 2. Removal of Iodine from Air Using a Nitric Acid Scrub in a Bubble-Cap Column; Part 3. Correlation of Mass-Transfer Data; Part 4. Process Sensitivity to Impurities, ORNL/TM-4701 (1975).

16. B. A. Hannaford, M. R. Gibson, and D. Sellinger, LMFBR Fue1 Reprocessing Program Progress Report for April 1 to June 30, 1976, ORNL/TM-5556, p. 41 (1976).

17. B. A. Hannaford, LMFBR Fuel Reprocessing Program Progress Report for Period July 1 to September 30, 1976, ORNL/TM-5668, p. 50 (1976).

18. B. A. Hannaford, personal communication to D. W. Holladay, ORNL, October 1976.

19. B. A. Hannaford, Advanced Fuel Recycle Program Progress Report for Period April 1 to June 30, 1977, ORNL/TM-5993, pp. 3-16 (1977).

20. B. A. Hannaford and R. T. Jubin, Advanced Fuel Recycle Program Progress Report for Period July 1 to September 30, 1977, ORNL/TM-6092, pp. 3-13 (1977).

21. E. D. Collins and D. E. Benker, Iodox Report Tests in a Transuranium Element Production Campaign, ORNL/TM-6182 (in preparation).

22. B. A. Hannaford and R. T. Jubin, Advanced Fuel Recycle Program Progress Report for Period January 1 to March 31, 1978, ORNL/TM-6306, pp. 3-27 (1978).

23. W. E. Clark, "The Isolation of Radioiodine with Portland Cement. Part I: Scoping Leach Studies," Nucl. Technol. 36, 215 (1977).

24. E. L. Nicholson, personal communication to O. O. Yarbro, ORNL, Mar. 25, 1977.

25. W. S. Groenier and B. A. Hannaford, personal communication to E. L. Nicholson, ORNL, Apr. 18, 1977.

26. D. J. Crouse, J. M. Schmitt, and F. G. Seeley, LMFBR Fuel Cycle Studies Progress Report for September, 1969, No. 7, ORNL/TM-2748, p. 43 (1969).

27. R. E. Adams, R. L. Bennett, and Ruth Slusher, Aqueous Processing of LMFBR Fuels Progress Report, April 1969, No. 2, ORNL/TM-2585, p. 26 (1969). 
28. R. E. Adams, R. L. Bennett, and Ruth Slusher, Aqueous Processing of LMFBR Fuels Progress Report, May 1969, No. 3, ORNL/TM-2624, p. 29 (1969).

29. J. M. Schmitt, D. J. Crouse, and W. B. Howerton, LMFBR Fuel Cycle Studies Progress Report for November, 1971, No. 33, ORNL/TM-3663, p. 23 (1972).

30. D. J. Crouse, J. M. Schmitt, and W. B. Howerton, LMFBR Fuel Cycle Studies Progress Report for March, 1972, No. 37, ORNL/TM-3807, p. 18 (1972).

31. D. E. Ferguson et a1., Chemica1 Technology Division Annua1 Progress Report for Period Ending May 31, 1970, ORNL-4572, p. 68 (1970).

32. J. M. Schmitt, D. J. Crouse, and W. B. Howerton, LMFBR Fuel Cycle Studies Progress Report for December 1971, No. 34, ORNL/TM-3698, p. 17 (1972).

33. J. M. Schmitt, D. J. Crouse, and W. B. Howerton, LMFBR Fuel Cycle Studies Progress Report for January 1972, ORNL/TM-3724, p. 18 (1972).

34. D. J. Crouse and W. B. Howerton, LMFBR Fuel Cycle Studies Progress Report for August 1972, No. 42, ORNL/TM-3993, p. 28 (1972).

35. D. J. Crouse and W. B. Howerton, LMFBR Fuel Cycle Studies Progress Report for June 1972, No. 40, ORNL/TM-3924, p. 11 (1972).

36. J. M. Schmitt, D. J. Crouse, and W. B. Howerton, LMFBR Fuel Cycle Studies Progress Report for July 1972, No. 41, ORNL/TM-3952, p. 17 (1972).

37. D. J. Crouse, J. M. Schmitt, and W. B. Howerton, Aqueous Fue1 Reprocessing Quarterly Report for Period Ending December 31, 1972, ORNL/TM-4141, p. 45 (1972).

38. D. J. Crouse, J. M. Schmitt, and W. B. Howerton, Aqueous Fue1 Reprocessing Quarterly Report for Period Ending March 31, 1973, ORNL/TM-4240, p. 30 (1973).

39. D. J. Crouse and W. B. Howerton, Aqueous Fuel Reprocessing Quarterly Report for Period Ending June 30, 1973, ORNL/TM-4301, p. 33 (1973).

40. 0. 0. Yarbro, G. I. Cathers et a1., LMFBR Fuel Cycle Studies Progress Report for September 1969, No. 7, ORNL/TM-2748, p. 36 (1969).

41. 0. 0. Yarbro, G. I. Cathers et al., LMFBR Fuel Cycle Studies Progress Report for February 1970, No. 12, ORNL/TM-2918, p. 25 (1970). 
42. "Airborne Waste Recovery and Immobilization," in Alternatives for Managing Wastes from Reactors and Post-Fission Operations in the LWR Fuel Cycle, ERDA-76/43, vol. II (May 1976).

43. J. G. Moore, personal communication to D. W. Holladay, ORNL, May 22, 1978 .

44. M. E. Weech and M. Ross, unpublished work, May 1967. This reference is quoted from the following reference: Walton A. Rodger and Stanton L. Reese, "The Removal of Iodine from Reprocessing-Plant Effluents," React. Fuel-Process. Technol. 12(2), 173 (1969).

45. J. G. Wilhelm, Iodine Filters in Nuclear Power Stations, KFK-2449 (April 1977).

46. A. G. Evans, "Effect of Alkali Metal Content of Carbon on Retention of Iodine at High Temperatures," p. 743 in Proceedings of the 13th AEC Air Cleaning Conference, CONF-740807 (1974).

47. R. E. Adams, R. D. Ackley, and R. P. Shields, "Application of Impregnated Charcoals for Removing Radioiodine from Flowing Air at High Humidity," pp. 387-402 in Treatment of Airborne Radioactive Wastes, Symposium Proceedings, New York, Aug. 26-30, 1968, IAEA, Vienna (1968) (ST1/PUB/195).

48. V. R. Dietz and C. H. Blachly, "New Charcoal Impregnants for Trapping Methyl Iodide I. Salts of the Iodine Oxyacids with Iodide for Iodine and Hexamethylenetetramine," in Proceedings of the 14th ERDA Air Cleaning Conference, CONF-760822 (1976).

49. J. L. Kovach and J. R. Hunt, "Iodine Fission Product Mass Transfer in Adsorbent Media," p. 736 in Proceedings of the 13th AEC Air Cleaning Conference, CONF-740807 (1974).

50. C. A. Burchsted, A. B. Fuller, and J. E. Kahn, Nuclear Air Cleaning Handbook, ERDA-76-21 (1976).

51. Regulatory Guide 1.52, Design, Testing, and Maintenance Criteria for Atmosphere Cleanup System Air Filtration and Adsorption Units of Light-Water-Cooled Nuclear Power Plants, U.S. Atomic Energy Commission, Washington, D.C. (1973).

52. ANSI N509, Nuclear Power Plant Air Cleaning Units and Components, American National Standards Institute, New York (1976).

53. RDT/M/16-1, Gas-Phase Adsorbents for Trapping Radioactive Iodine and Iodine Compounds, ERDA, current issue. 
54. B. Deckers, P. Sigli, and L. Trehen, "Operating Experience with the Testing of Iodine Adsorbers on the Air Cleanup Systems of the Belgian PWR Power Plants," p. 432 in Proceedings of the 14th ERDA Air Cleaning Conference, CONF-760822 (1976).

55. R. L. Ritzman and J. M. Genco, Evaluation of Data Regarding the Efficiency of Activated Charcoal Adsorbers at Low Gas Phase Iodine Concentrations, WASH-1231 (1972).

56. R. R. Bellamy, "Elemental Iodine and Methy1 Iodide Adsorption on Activated Charcoal at Low Concentrations," p. 683 in Proceedings of the 13th AEC Air Cleaning Conference, CONF-740807 (1974).

57. W. E. Browning, Jr., et al., "Removal of Iodine and Volatile Iodine Compounds from Air System by Activated Charcoal," Nuclear Safety Program Semiannual Progress Report for Period Ending June 30, ORNL-3843 (1965).

58. R. E. Adams and W. E. Browning, Jr., Iodine Vapor Adsorption Studies for the Nuclear Ship Savannah Project, ORNL-3726 (1965).

59. R. E. Adams, W. E. Browning, Jr., W. B. Cottrell, and G. W. Parker, The Release and Adsorption of Methyl Iodide in the HFIR Maximum Credible Accident, ORNL/TM-1291 (1965).

60. D. A. Collins, L. R. Taylor, and R. Taylor, The Development of Impregnated Charcoals for Trapping Methyl Iodide at High Humidity, TRG Report 1300W (1967).

61. R. A. Lorenz, S. R. Manning, and W. J. Martin, "The Behavior of Highly Radioactive Iodine on Charcoal in Moist Air," p. 323 in Proceedings of the 14th ERDA Air Cleaning Conference, CONF-760822 (1976).

62. V. R. Deitz, C. H. Blachly, and L. A. Jonas, "Dependence of Gas Penetration of Charcoal Beds on Residence Time and Linear Velocity," in Proceedings of the 14th ERDA Air Cleaning Conference, CONF-760822 $(1976)$.

63. A. G. Evans, "Effect of Intense Gamma Radiation on Radioiodine Retention by Activated Carbon," p. 401 in Proceedings of the 12th AEC Air Cleaning Conference, CONF-720823 (1972).

64. J. D. Ludwick, The Iodine Collection Efficiency of Activated Charcoa1 from Hanford Reactor Confinement Systems: Methy1 Iodide Retention by Activated Charcoal, BNWL-1046 (1969).

65. R. D. Ackley, Zell Combs, and R. E. Adams, Aging, Weathering, and Poisoning of Impregnated Charcoals Used for Trapping Radioiodine, ORNL/TM-2860 (1970). 
66. R. C. Milham, "Charcoal Post-Treatment; Heat Degradation and Service Life," p. 167 in Proceedings of the 10th AEC Air Cleaning Conference, CONF-680821 (1968).

67. R. C. Milham and L. R. Jones, Iodine and Noble Gas Retention Studies Progress Report: Oct. 1966-Dec. 1968, DP-1209 (1969).

68. A. G. Evans and L. R. Jones, Iodine Retention Studies-Progress Report July 1970-December 1970, DP-1271 (1971).

69. R. J. Davis and R. D. Ackley, "Long Term Effects on Radioiodine Trapping by Charcoal," p. 469 in Proceedings of the 12th AEC Air Cleaning Conference, CONF-720833 (1972).

70. R. E. Adams, R. D. Ackley, and Ze11 Combs, "Effect of Organic Solvents in Retention of Iodine by Iodized Charcoal," in Aqueous Processing of LMFBR Fuels Program Report, May, 1969, ORNL/TM-2624 (1969).

71. R. G. Pope and J. J. Smith, ORNL Inspection Engineering Department, unpublished work.

72. M. J. Kabat, "Testing and Evaluation of Adsorbers for Gaseous Penetrative Forms of Radioiodines," p. 765 in Proceedings of the 13th AEC Air Cleaning Conference, CONF-740807 (1974).

73. H. C. Parish and R. C. Muhlenhaupt, "A Method for Correlating Weathering Data on Adsorbents Used for the Removal of $\mathrm{CH}_{3} \mathrm{I}, "$ p. 266 in Proceedings of the 14th ERDA Air Cleaning Conference, CONF-760822 (1976).

74. J. R. Hunt, R. Lubbers, and J. L. Kovach, "Iodine Removal Adsorbent Histories, Aging, and Regeneration," p. 287 in Proceedings of the 14th ERDA Air Cleaning Conference, CONF-760822 (1976).

75. R. A. Lorenz, W. J. Martin, and H. Nagao, "The Behavior of Highly Radioactive Iodine on Charcoal," p. 707 in Proceedings of the 13th AEC Air Cleaning Conference, CONF-740807 (1974).

76. R. P. Shields, "Ignition of Charcoal Adsorbers by Fission Product Decay Heat," p. 770 in Proceedings of the 11th AEC Air Cleaning Conference, CONF-700816 (1970).

77. E. A. Bernard and R. V. Zanadoski, "The Calculation of Charcoal Heating in Air Filtration Systems," p. 845 in Proceedings of the 13th AEC Air Cleaning Conference, CONF-74080.7 (1975).

78. R. E. Adams and R. P. Shields, Ignition of Charcoal Adsorbers by Fission Product Decay Heat, ORNL/TM-2095 (1968). 
79. J. L. Kovach and J. E. Green, "Evaluation of the Ignition Temperature of Activated Charcoals in Dry Air," Nucl. Safety 8,41 (1966).

80. A. G. Evans, Confinement of Airborne Radioactivity - Progress Report July 1972 to December 1972, DP-1329, p. 10 (1973).

81. R. E. Adams et al., Removal of Radioactive Methyl Iodide from SteamAir Systems, ORNL-4040 (1967).

82. R. D. Ackley and R. E. Adams, Removal of Radioactive Methyl Iodide from Steam-Air Systems (Test Series II), ORNL-4180 (1967).

83. D. A. Collins, L. R. Taylor, and R. Taylor, "The Development of Impregnated Charcoals for Trapping Methyl Iodide at High Humidity," p. 159 in Proceedings of the 9th AEC Air Cleaning Conference, CONF-660904 (1966).

84. R. D. Rivers, M. Pasha, and W. H. Buckler, "Correlation of Radioiodine Efficiencies Resulting from a Standardized Test Program for Activated Carbon," p. 445 in Proceedings of the 12th AEC Air Cleaning Conference, CONF-720823 (1972).

85. A. H. Dexter, A. G. Evans, and L. R. Jones, Confinement of Airüorne Radioactivity, DP-1390 (October 1975).

86. D. T. Pence, F. A. Duce, and W. J. Maeck, "Adsorption Properties of Metal Zeolites for Airborne Iodine Species," p. 581 in Proceedings of the Eleventh AEC Air Cleaning Conference, CONF-700816 (1970).

87. W. J. Maeck, D. T. Pence, and J. H. Keller, "Highly Efficient Inorganic Adsorber for Airborne Iodine Species," p. 185 in Proceedings of the Tenth AEC Air Cleaning Conference, CONF-680821 (1968) .

88. R. D. Ackley and Zell Combs, Applicability of Inorganic Sorbents for Trapping Radioiodine from LMFBR Fue1 Reprocessing off-Gas, ORNL/TM-4227 (1973).

89. D. T. Pence, F. A. Duce, and W. J. Maeck, "Developments in the Removal of Airborne Iodine Species with Metal-Substituted Zeolites," p. 417 in Proceedings of the Twelfth AEC Air Conference, CONF-720823 (1972).

90. B. A. Staples, L. P. Murphy, and T. R. Thomas, "Airborne Elemental Iodine Loading Capacity of Metal Zeolites and a Dry Method for Recycling Silver Zeolite," p. 363 in Proceedings of the 14th ERDA Air Cleaning Conference, CONF-760822 (1976).

91. W. J: Maeck and D. T. Pence, "Application of Metal Zeolites to Radioiodine Air Cleaning Problems," p. 607 in Proceedings of the Eleventh AEC Air Cleaning Conference, CONF-700816 (1970). 
92. D. T. Pence and B. A. Staples, "Solid Adsorbents for Collection and Storage of Iodine-129 from Reprocessing Plants," p. 758 in Proceedings of the 13th AEC Air Cleaning Conference, CONF-740807 (1974).

93. R. D. Ackley and R. J. Davis, Effect of Extended Exposure to Simulated LMFBR Fuel Reprocessing Off-Gas on Radiolodine Trapping Performance of Sorbents (Final Report), ORNL/TM-4529 (August 1974).

94. J. G. Wilhelm, J. Furrer, and E. Schultes, "Head-End Iodine Removal from a Reprocessing Plant with a Solid Sorbent," p. 447 in Proceedings of the 14th ERDA Air Cleaning Conference, CONF-760822 (1976).

95. J. G. Wilhelm and H. Schuettelkopf, "Inorganic Adsorber Materials for Trapping of Fission Product Iodine," p. 568 in Proceedings of the Eleventh AEC Air Cleaning Conference, CONF-700816, vol. 2 (1970).

96. K. C. Patil et al., "The Silver Nitrate-Iodine Reaction: Iodine Nitrate as the Intermediate," J. Inorg. Nucl. Chem. 29, 407 (1967).

97. J. G. Wilhelm and H. Schuettelkopf, "An Inorganic Adsorber Material for Off-Gas Cleaning in Fuel Reprocessing Plants," p. 540 in Proceedings of the 12th AEC Air Cleaning Conference, CONF-720823 (1972).

98. L. C. Lewis, Evaluation of Adsorbents for Purification of Noble Gases in Dissolver Off-Gas, IN-1402 (July 1970).

99. D. T. Pence and T. R. Thomas, $\mathrm{NO}_{\mathrm{x}}$ Abatement at Nuclear Processing Plants, WASH-1332(74), vol. I, pp. 427-45 (July 1974).

100. N. R. Leist, J. J. Buckhold, and D. E. Keck, The Design and Operation of a Pilot Plant Unit for $\mathrm{NO}_{x}$ Destruction with Ammonia and a Synthetic Mordenite Catalyst, NLCO-1139 (February 1977).

101. Norton Company, P. O. Box 350, Akron, Ohio, "Zeolon Acid Resistant Molecular Sieves," Bulletin Z-51.

102. C. M. Slansky et a1., LWR Fuel Reprocessing and Recycle Progress Report for July 1-September 30, 1976, ICP-1108 (1976).

103. C. M. Slansky et a1., LWR Fuel Reprocessing and Recycle Progress Report for October 1-December 31, 1976, ICP-1110 (1977).

104. C. M. Slansky et al., LWR Fuel Reprocessing and Recycle Progress Report for January 1-March 31, 1977, ICP-1116 (1977).

105. L. P. Murphy, B. A. Staples, and T. R. Thomas, The Development of $\mathrm{Ag}^{\circ} \mathrm{Z}$ for Bulk ${ }^{129} \mathrm{I}$ Removal from Nuclear Fuel Reprocessing Plants and $\mathrm{PbX}$ for 129I Storage, ICP-1135 (December 1977). 
106. T. R. Thomas, L. P. Murphy, B. A. Staples, and J. J. Nichols, Airborne Elemental Iodine Loading Capacities of Metal Zeolites and a Method for Recycling Silver Zeolite, ICP-1119 (1977).

107. J. G. Moore and W. B. Howerton, LMFBR Fuel Cycle Studies Progress Report for July 1970, No. 17, ORNL/TM-3095, p. 30 (1970).

108. J. G. Moore and W. B. Howerton, LMFBR Fuel Cycle Studies Progress Report for September 1970, No. 19, ORNL/TM-3180, p. 23 (1970).

109. J. G. Moore and W. B. Howerton, LMFBR Fuel Cycle Studies Progress Report for April 1971, No. 26, ORNL/TM-3412, p. 31 (1971).

110. J. G. Moore and W. B. Howerton, LMFBR Fuel Cycle Studies Progress Report for January 1971, No. 23, ORNL/TM-3312, p. 36 (1971).

111. D. E. Ferguson et al., Chemical Technology Division Annual Progress Report for Period Ending March 31, 1971, ORNL-4682 (1971).

112. A. E. J. Eggleton, A Theoretical Examination of Iodine-Water Partition Coefficients, AERE- R-4887 (1967).

113. M. Kahn and J. Kleinberg, Radiochemistry of Iodine, prepared for Subcommittee on Radiochemistry, NAS-NRC, NAS-NS-3062 (September 1977).

114. W. Davis, Jr., and A. H. Kibbey, Spectrochemistry and Spectrum Resolution of Some Iodine Species in Acidic, Neutral, and Basic Solutions, ORNL-4742 (January 1972).

115. L. G. Suhr and G. L. Culp, "State of the Art - Activated Carbon Treatment of Wastewater," Water and Sewage Works, Ref. No.'9-104 (1974).

116. E. J. Lehmann, Activated Carbon. A Bibliography with Abstracts. Report for 1964-1974, COM-74-11529 (1974); also Nuc1. Sci. Abs. 32, 180 (1975).

117. E. A. Sigworth and S. B. Smith, "Adsorption of Inorganic Compounds by Activated Carbon," J. Amer. Water Works Assoc. 64, 386 (June 1972).

118. F. G. Sawyer, M. F. Ohman, and F. E. Lusk, "Iodine from Oil Well Brines," Ind. Eng. Chem. 41(8), 1547 (1949).

119. E. R. Graham, M. W. Clark, and V. E. Renner, Removal of Radioactive Fission Products from Surface Water Supplies, Research Bulletin 787, Univ. of Missouri, College of Agriculture, Agricultural Experiment Station (November 1961).

120. Westvaco Product Data Bulletins for Nuclear Granular Activated Carbon, Westvaco Chemical Division, Covington, Va.

121. E. G. Kreusch and F. F. Jusseini, "Iodine-Treated Activated Carbon for Treating Contaminated Water," U.S. Patent 3,772,189 (Nov. 13, 1973); Chem. Abs. 80, 52169h (1974). 
122. R. C. Bansal, S. S. Bhardwaj, D. K. Mahajan, and B. R. Puri, "Adsorption Characteristics of Carbons Obtained from Polyvinyl Chloride," Indian J. Chem. 13, 140 (1975).

123. A. B. Belogovskii, V. A. Galkin, V. N. Golubev, and B. N. Aleshin, "Desorption of Iodine from Active Carbon by Caustic Alkali Solution in an U1trasonic Field," J. App1. Chem. 47(11), 2637 (1974).

124. V. P. Ilinski and A. N. Strelnikova, "Vapor Pressure and Distribution of Iodine for Aqueous Salt Solutions," Tr. Leningr. Khim. Farm. Inst. $\underline{5}, 32$ (1956).

125. J. G. Moore and W. B. Howerton, LMFBR Fuel Cycle Studies Progress Report for December 1970, ORNL/TM-3281, p. 27 (1971).

126. M. Ziegler, "Sorption of Bromine and Iodine by Anion Exchanger," Angew. Chem. 71, 283 (1959).

127. A. R. Giona, "Adsorption of Gas-Phase Iodine on Dry Ion-Exchange Resins," Brit. Chem. Eng. 10(2), 82-85 (1965).

128. B. Sansoni, "Specific Molecular Adsorption of Iodine on Anion Exchangers," Angew. Chem. 73, 493 (1961).

129. J. G. Moore and W. B. Howerton, LMFBR Fuel Cycle Studies Progress Report for July 1970, No. 17, ORNL/TM-3095, p. 30 (1970).

130. J. G. Moore and W. B. Howerton, LMFBR Fuel Cycle Studies Progress Report for August 1970, No. 18, ORNL/TM-3127, p. 33 (1970).

131. J. G. Moore and W. B. Howerton, LMFBR Fuel Cycle Studies Progress Report for November 1970, No. 21, ORNL/TM-3250, p. 34 (1970).

132. J. G. Moore and W. B. Howerton, LMFBR Fuel Cycle Studies Progress Report for December 1970, No. 22, ORNL/TM-3281, p. 27 (1970).

133. J. G. Moore and W. B. Howerton, LMFBR Fuel Cycle Studies Progress Report for January 1971, No. 23, ORNL/TM-3312, p. 36 (1971).

134. J. L. Swanson, J. A. Partridge, and J. L. Cox, LWR Fuel Recycle Program Quarterly Progress Report, July-Sept. 1976, BNWL-2080-2 (1976).

135. J. L. Swanson et al., LWR Fuel Recycle Program Quarterly Progress Report, Oct.-Dec. 1976, BNWL-2080-3, p. 30 (1977).

136. J. L. Swanson et a1., LWR Fuel Recycle Program Quarterly Progress Report, Jan.-March 1977, BNWL-2080-4, p. 21 (1977).

137. N. D. Ivanov, "Sorption of Iodine by AV-17 Anion Exchange Resin in Various Salt Forms," J. App1. Chem. 47(3), 490 (March 1974). 
138. S. Yokotsuka, E. Akatsu, and K. Ueno, "Ion Exchange Behaviors of Inorganic Ions in Ion Exchange Resins of Diaion SKN-1 and SAN-1: Distribution Ratios of Ions in the System of Diaion-Hydrochloric Acid," J. Nuc1. Sci. Technol. 8(11), 622 (1971).

139. E. Akatsu and Y. Aratono, "Ion Exchange Behaviors of Some Inorganic Ions in System of Ion Exchange Resins of Porous Type," J. Nuc1. Sci. Technol. 10(8), 453 (1973).

140. O. R. Skorokhod and M. K. Sembur, "Ion Exchangers and Ion Exchange (in Russian)," Izd. "Nauka," Moscow, p. 156 (1966).

141. F. Ne1son, T. Murase, and K. A. Kraus, "Ion Exchange Procedures:

I. Cation Exchange in Concentrated HCl and HC104 Solutions,"

J. Chromatogr. 13, 503 (1964).

142. D. G. Easterly, I. B. Brooks, and J. K. Hasuike, Development of Ion Exchange Processes for the Removal of Radionuclides from Milk, ROEERL 71-1 (1971).

143. J. L. Swanson, LWR Fue1 Recycle Program Quarterly Progress Report January-March 1977, BNWL-2080-4 (April 1977).

144. J. S. Zuljevic and R. H. H. Wolf, "Sorption of Lanthanum (III), Cobalt (II), and Iodide Ions at Trace Concentrations on Ferric Hydroxide," Mikrochim. Acta 2, 315 (1973).

145. N. V. Brevnova, E. V. Bekisheva, Y. K. Kirilenko, L. A. Volf, and A. I. Meos, "The Use of a Fibrous Sulfonate-Sorbent for the Isolation of Radioactive Iodine," Sov. Radiochem. 13, 462 (1971).

146. J. L. Swanson, LWR Fuel Recycle Program Quarterly Progress Report Oct.-Dec. 1976, BNWL-2080-3, p. 29 (1977).

147. G. P. Simon, C. S. Abrams, and W. T. Lindsay, Jr., The Performance of Base-Form Ion Exchangers for $\mathrm{pH}$ Control and Removal of Fission Products from Pressurized Water Reactors, WAPD-CDA(AD)-528 (1959).

148. W. C. Yee, F. Delora, and W. E. Shockley, Low-Level Radioactive Waste Treatment: The Water Recycle Process, ORNL-4472 (1970).

149. W. D. Fletcher, Ion Exchange in Boric Acid Solutions with Radioactive Decay, WCAP-3716 (November 1962).

150. J. Weisman and S. Bartnoff, The Saxton Chemical Skim Experiment, WCAP-3269-24 (July 1965).

151. P. Cohen and G. R. Taylor, Ion Exchange with Equilibrium and Decay, WCAP-1700 (January 1961).

152. K. H. Lin, Use of Ion Exchange for the Treatment of Liquids in Nuclear Power Plants, ORNL-4792 (December 1973). 
153. B. N. Dickinson and I. R. Higgins, "Selective Ion-Exchange Sorption of Cesium-137 and Iodine-131 from Borated Solutions," Nuc1. Sci. Eng. 27, 131 (1967).

154. B. A. Hannaford, personal communication to D. W. Holladay, ORNL, November 1977. 
ORNL/ TM-6350

INTERNAL DISTRIBUTION

1. M. Bender

2. R. E. Blanco

3. J. O. Blomeke

4. W. D. Burch

5. W. L. Carter

6. J. M. Chandler

7. W. E. Clark

8. E. D. Collins

9. R. M. Counce

10. D. J. Crouse

11. D. E. Ferguson

12. W. S. Groenier

13. G. L. Haag

14. B. A. Hannaford

15. F. E. Harrington

16-35. D. W. Holladay

36. V. A. Jacobs

37. R. T. Jubin

38. S. V. Kaye

39. A. D. Kelmers

40. J. Q. Kirkman

41. W. J. Lackey

42. C. E. Lamb

43. R. E. Leuze

44. K. H. Lin

45. R. A. Lorenz
46. A. L. Lotts

47. J. C. Mailen

48. J. R. Merriman

49. E. L. Nicholson

50. K. J. Notz

51. A. R. O1sen

52. R. H. Rainey

53. D. P. Reid

54. A. D. Ryon

55. J. W. Snider

56. B. B. Spencer

57. R. G. Stacy

58. J. E. Van Cleve

59. V. C. A. Vaughen

60. R. G. Wymer

61-62. Central Research Library

63. Document Reference Section

64-68. Laboratory Records

69. Laboratory Records, RC

70. ORNL Patent Section

71. G. R. Choppin (consultant)

72. L. J. Colby, Jr. (consultant)

73. E. L. Gaden, Jr. (consultant)

74. L. E. Swabb, Jr. (consultant)

75. K. D. Timmerhaus (consultant)

\section{EXTERNAL DISTRIBUTION}

76. C. Bartlett, Chief, Fuel Cycle Research Branch, Division of Fue1 Cycle and Environmental Research, U.S. Nuclear Regulatory Commission, Mail Stop SS 1130, Washington, D.C. 20555

77. S. J. Beard, Fue1 Reprocessing Engineering, Exxon Nuclear Co., Inc., 777 106th Avenue, NE, Bellevue, Washington 98009

78. W. P. Bishop, Assistant Director for Waste Management, Division of Fue1 Cycle and Material Safety, U.S. Nuclear Regulatory Comnission, Washington, D.C. 20555

79. W. F. Bonner, Pacific Northwest Laboratories, Battelle Boulevard, Richland, Washington 99352

80. J. A. Buckham, Allied-General Nuclear Services, P. O. Box 847, Barnwe11, S.C. 29812.

81. A. B. Carson, FBR Department, Energy R and T Division, General Electric Company, 175 Curtner Avenue, San Jose, California 95100

82. R. N. Case, Allied Chemical, 550 2nd St., Idaho Falls, Idaho 83401

83. J. P. Duckworth, Nuclear Fuel Services, Inc., P. O. Box 124, West Valley, New York 14171 
84. Harry Groh, E. I. duPont deNemours Co., Inc., Savannah River Plant, Aiken, S.C. 29801

85. C. Heath, Director, Division of Waste Isolation, Office of Nuclear Waste Management, U.S. Department of Energy, 400 First Street, N.W., Washington, D.C. 20545

86. L. R. Hill, Supervisor, Nuclear Waste Technology Division, Sandia Laboratories, Mai1 Drop 5311, Sandia, New Mexico 87115

87. E. R. Irish, Pacific Northwest Laboratories, Battelle Boulevard, Richland, Washington 99352

88. L. Jardine, Argonne National Laboratory, Chemical Engineering Division, Argonne, Illinois 60439

89. J. H. Jarrett, Pacific Northwest Laboratories, Battelle Boulevard, Richland, Washington 99352

90-101. D. E. Large, Department of Energy, Oak Ridge Operations, P. O. Box E, Oak Ridge, Tennessee 37830

102. Office of Assistant Manager. Energy Research and Development, P. O. Box E, Oak Ridge, Tennessee 37830

103. W. H. Lewis, Vice President, Nuclear Fuel Services, Inc., 6000 Executive Blvd., Rockville, Maryland 20852

104. J. E. Mendel, Pacific Northwest Laboratories, Battelle Blvd., Richland, Washington 99352

105. L. H. Meyer, Savannah River Laboratory, E. I. duPont deNemours and Co., Inc., Aiken, S.C. 29801

106. J. L. McElroy, Pacific Northwest Laboratories, Battelle Boulevard, Richland, Washington 99352

107. A. D. Miller, EPRI, 3412 Hillview Ave., P. O. Box 10412, Palo Alto, California . 94303

108. M. A. Molecke, Nuclear Waste Technology Division, Sandia Laboratories, Sandia, New Mexico 87115

109-113. G. Oerte1, Director, Division of Waste Products, Office of Nuclear Waste Management, U.S. Department of Energy, Washington, D.C. 20545

114. D. A. Orth, Savannah River Plant, E. I. duPont deNemours and Co., Inc., Aiken, S.C. 29801

115. A. M. Platt, Pacific Northwest Laboratory, P. O. Box 999, Richland, Washington 99352

116. R. Roy, Materials Research Laboratory, Pennsylvania State Univ., University Park, Pennsylvania 16802

117. A. R. Sattler, Nuclear Waste Technology Division, Sandia Laboratories, Sandia, New Mexico 87115

118. L. W. Scully, Nuclear Waste Technology Division, Sandia Laboratories, Sandia, New Mexico 87115

119. J. J. Shefcik, General Atomic Company, P. O. Box 81608, San Diego, California 92138

120. M. T. Steindler, Argonne National Laboatory, 9700 South Cass Avenue, Argonne, Illinois 60439

121. J. L. Swanson, Pacific Northwest Laboratory, P. O. Box 999, Richland, Washington, 99352

122. R. E. Tomlinson, Manager, Exxon Nuclear Company, Inc., 2101 Horn Rapids Road, Richland, Washington 99352 
123. J. B. Whitsett, Chief of Radioactive Waste Programs, DOE, IDO, 550 2nd St., Idaho Falls, Idaho 83401

124-150. Technical Information Center, DOE, Oak Ridge. 